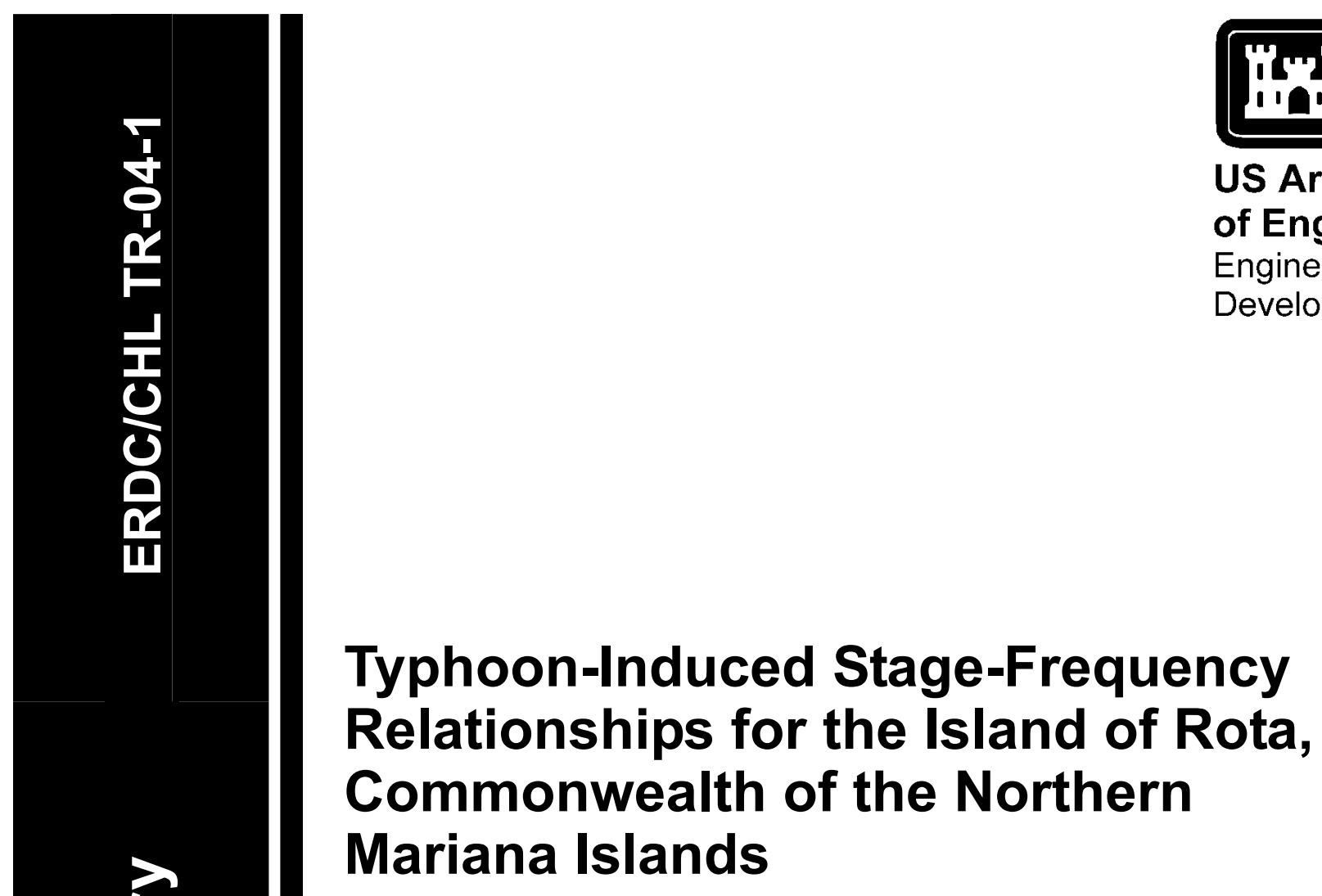

Edward F. Thompson and Norman W. Scheffner

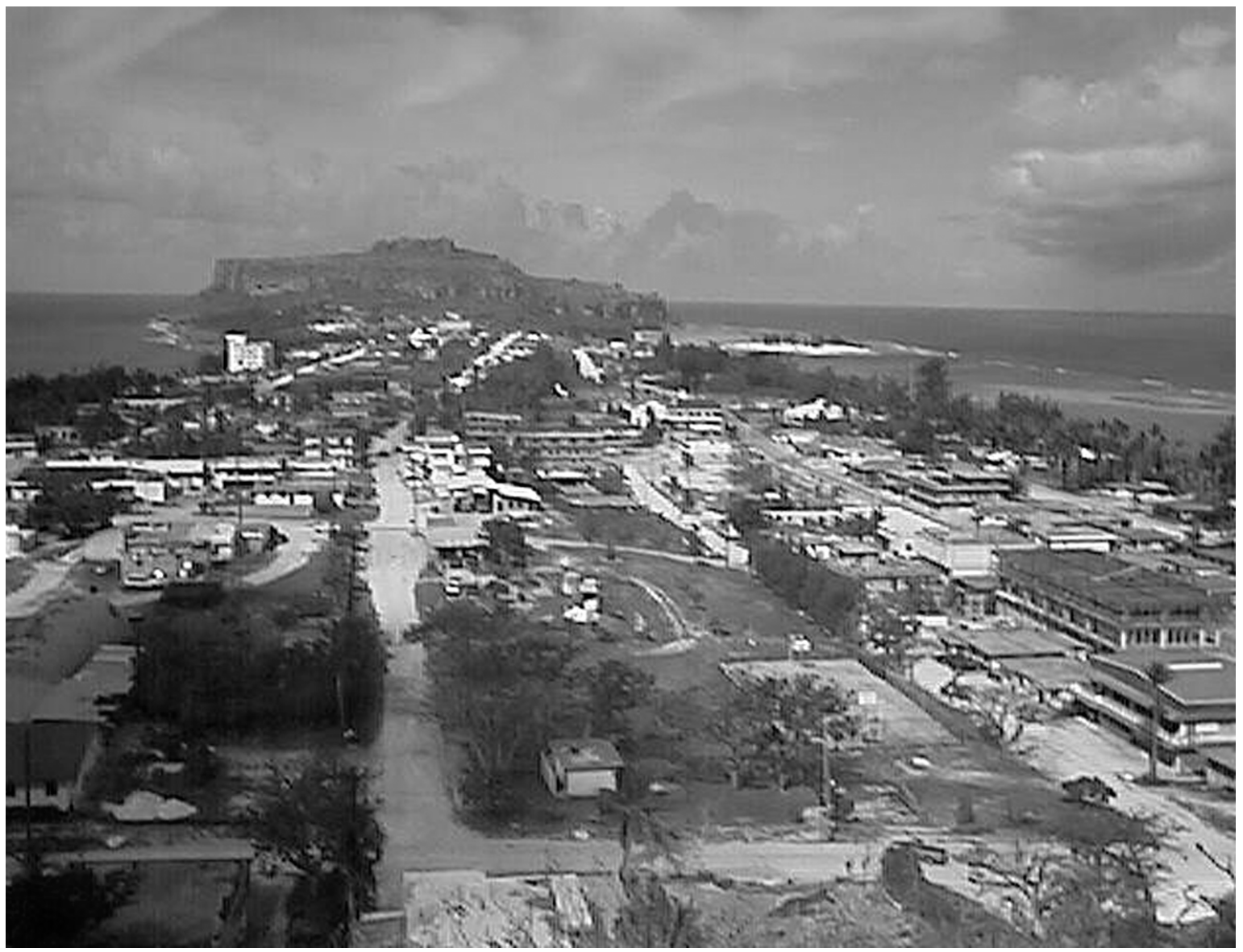




\title{
Typhoon-Induced Stage-Frequency Relationships for the Island of Rota, Commonwealth of the Northern Mariana Islands
}

\author{
Edward F. Thompson, Norman W. Scheffner \\ Coastal and Hydraulics Laboratory \\ U.S. Army Engineer Research and Development Center \\ 3909 Halls Ferry Road \\ Vicksburg, MS 39180-6199
}

Final report

Approved for public release; distribution is unlimited 


\begin{abstract}
:
A set of typhoon-induced stage-frequency relationships was developed for inhabited coasts of the island of Rota, Commonwealth of the Northern Mariana Islands. The objective was to assist the Honolulu District in estimating extreme maximum inundation levels and maximum still-water levels with return period of up to 500 years. Calculations of surge, wind and pressure field, and wave characteristics were performed for 28 historical storms and four hypothetical variations of historical storms through application of numerical models. Wave-induced ponding, setup, and runup were calculated at 87 profile locations specified by the Honolulu District. The Empirical Simulation Technique was applied to calculate stage-frequency relationships based on historical storm parameters and calculated response to the storms. These relationships were calculated from the maximum total water levels computed for each storm (including storm surge, ponding, and runup) and from the maximum still-water levels for each storm (including storm surge, ponding, and wave setup). The methodology was calibrated to observations so that stage-frequency values for maximum total water level are expected to represent maximum debris line inundation levels.
\end{abstract}

DISCLAIMER: The contents of this report are not to be used for advertising, publication, or promotional purposes. Citation of trade names does not constitute an official endorsement or approval of the use of such commercial products. All product names and trademarks cited are the property of their respective owners. The findings of this report are not to be construed as an official Department of the Army position unless so designated by other authorized documents. 


\section{Contents}

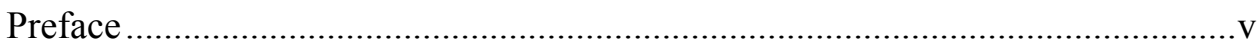

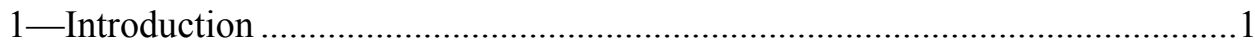

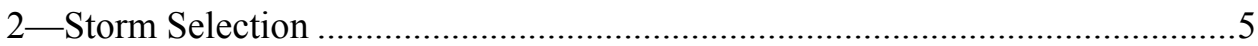

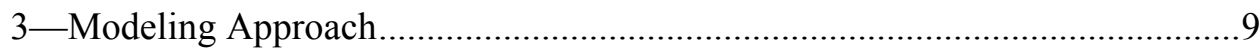

Wind and Atmospheric Pressure Field Model ............................................

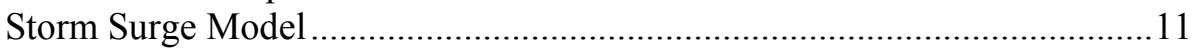

Wave and Wave Transformation Models ................................................16

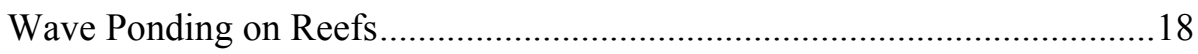

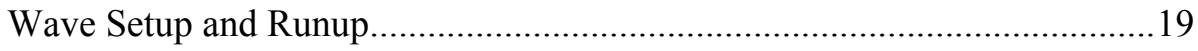

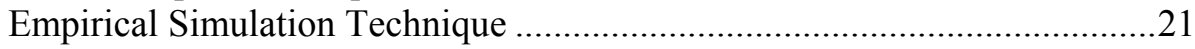

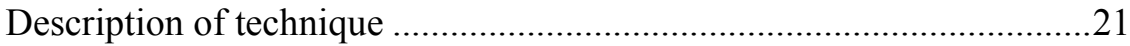

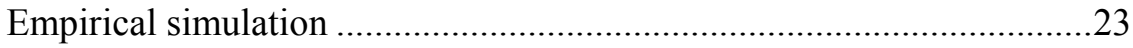

4-Implementation of Storm Surge Model .....................................................25

5-Development of Stage-Frequency Relationships .....................................2

Storm Surge/Tidal Elevation Relationship ..............................................27

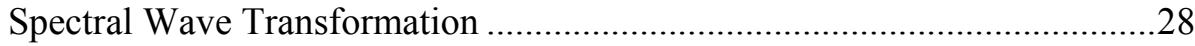

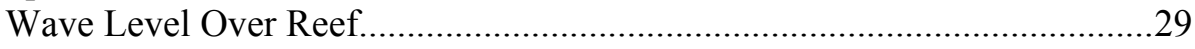

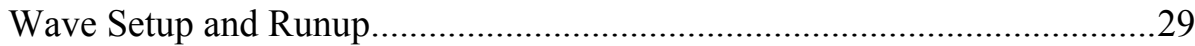

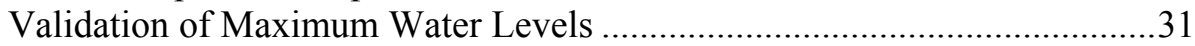

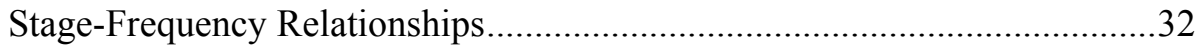

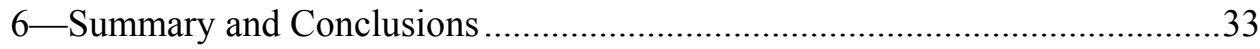

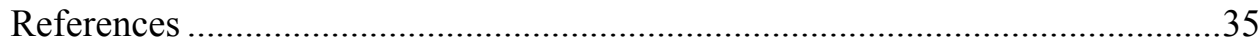

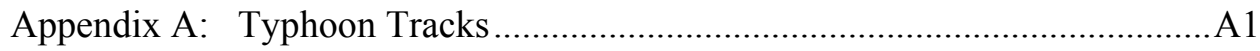

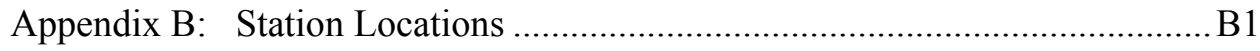

Appendix C: Profile Locations Keyed To Station Locations ............................. 1

Appendix D: Stage-Frequency Relationship Tables ……............................... 1 
Appendix E: Stage-Frequency Relationship Plots

Appendix F: Wave Parameter and Water Level Tables by Storm.

F1

SF 298

\section{List of Figures}

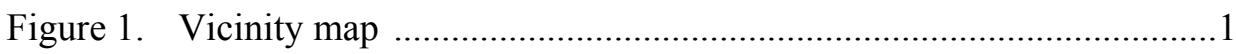

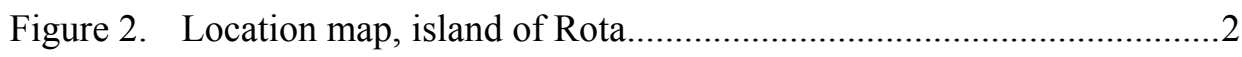

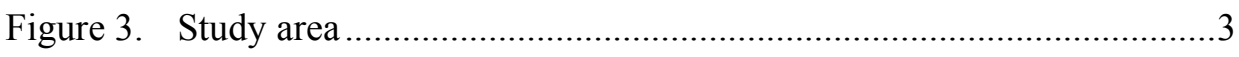

Figure 4. Complete computational grid for Rota study .................................14

Figure 5. Computational grid showing detail for Rota ...................................15

Figure 6. Computational grid showing detail for study area...........................15

Figure 7. Definition sketch of wave ponding and runup ...............................18

Figure 8. Model astronomical tide, Rota, January 1997 ................................26

Figure 9. Key nearshore storm surge station locations for Rota .....................28

\section{List of Tables}

Table 1. Typhoons Selected for Modeling, Island of Rota.............................. 8

Table 2. Statistics of Typhoon Travel Direction .......................................... 8

Table 3. Storm Surge Grid Parameters ....................................................... 14

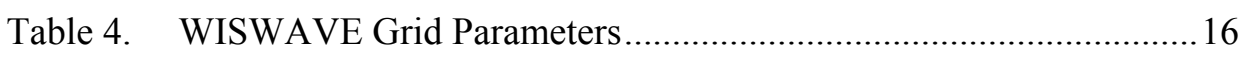

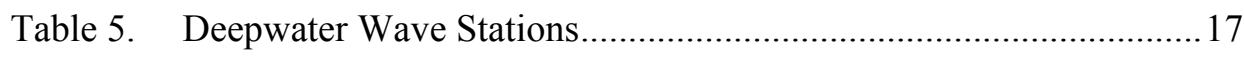

Table 6. Ponding Level Coefficients for Irregular Waves ........................... 19

Table 7. Comparison of Observed and Modeled Maximum Water Level.......32 


\section{Preface}

This report describes the procedures and results of a typhoon stage-frequency analysis for coastal study areas along the island of Rota, Commonwealth of the Northern Mariana Islands. The study was performed by the U.S. Army Engineer Research and Development Center (ERDC), Coastal and Hydraulics Laboratory (CHL), for the U.S. Army Engineer District, Honolulu. The study was conducted during the period January 1999 through May 2003. Mr. Steven H. Yamamoto, Honolulu District, was the study manager and point of contact.

The investigation reported herein was conducted by Dr. Edward F. Thompson of the Coastal Harbors and Structures Branch (CHSB), CHL, and Dr. Norman W. Scheffner, of the Estuarine Engineering Branch (EEB), CHL. Mr. David J. Mark, EEB, helped guide critical phases of the tide and storm surge modeling and overall study.

This study was performed under the general supervision of Mr. Thomas W. Richardson, Director, CHL. Direct supervision of this project was provided by Mr. Dennis Markle, Chief, CHSB.

At the time of publication of this report, Dr. James R. Houston was Director of ERDC, and COL James R. Rowan, EN, was Commander and Executive Director.

The contents of this report are not to be used for advertising, publication, or promotional purposes. Citation of trade names does not constitute an official endorsement or approval of the use of such commercial products. 


\section{Introduction}

The island of Rota is located in the western Pacific Ocean at long. $145.2^{\circ} \mathrm{E}$ and lat. $14.2^{\circ} \mathrm{N}$. Rota lies approximately midway between Japan and the northern tip of Australia (Figure 1). Rota is one of the Mariana Islands, an island chain at the southern end of a volcanic ridge stretching south from the Japanese island of Honshu. The island of Guam anchors the southern end of the chain. Rota lies $76 \mathrm{~km}$ (47 miles) north of Guam. The Mariana Trench, a deep rift in the ocean floor, wraps around Guam to the south and east and approximately parallels the northern Mariana Islands. The Mariana Island chain divides the Pacific Ocean on the east from the Philippine Sea on the west.

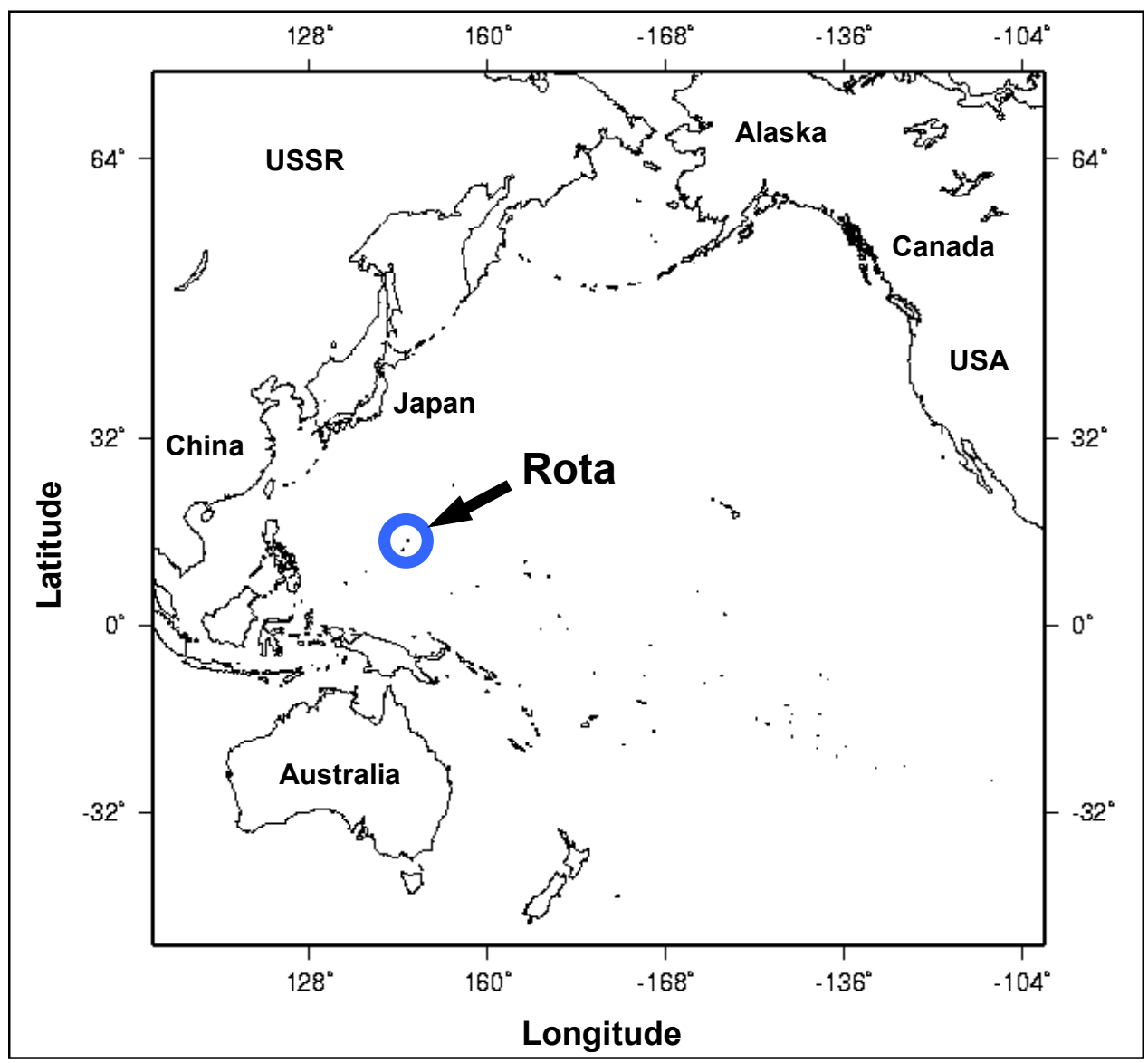

Figure 1. Vicinity map 
Politically, Rota is part of the Commonwealth of the Northern Mariana Islands (CNMI). The CNMI consists of 14 volcanic islands, with most of the population located on Saipan, $117 \mathrm{~km}$ (73 miles) north of Rota. Approximately 3,500 people inhabit Rota, and the island offers some tourist attractions and facilities. Rota is affiliated with the United States as a result of a trusteeship agreement established in the aftermath of World War II. The trusteeship agreement eventually matured into commonwealth status for Rota and the other northern Mariana Islands.

The island of Rota is approximately $17 \mathrm{~km}$ (10.5 miles) long and $5 \mathrm{~km}$ ( 3 miles) wide (Figure 2). It covers an area of $85 \mathrm{sq} \mathrm{km}$ (33 square miles). Most of the population resides in the island's western half. The principal community lies at the landward end of the tail-like Taipingot peninsula at the island's western tip. Most coastal shelf and beach areas are narrow, often with steep, rugged terrain inland of the coast, as is typical for volcanic islands. Fringing coral reefs are common around the island. Water depth over the reefs is very shallow and some reef areas are exposed at low tide. Thus, the reefs provide an important measure of natural protection to coastal areas from damaging waves.

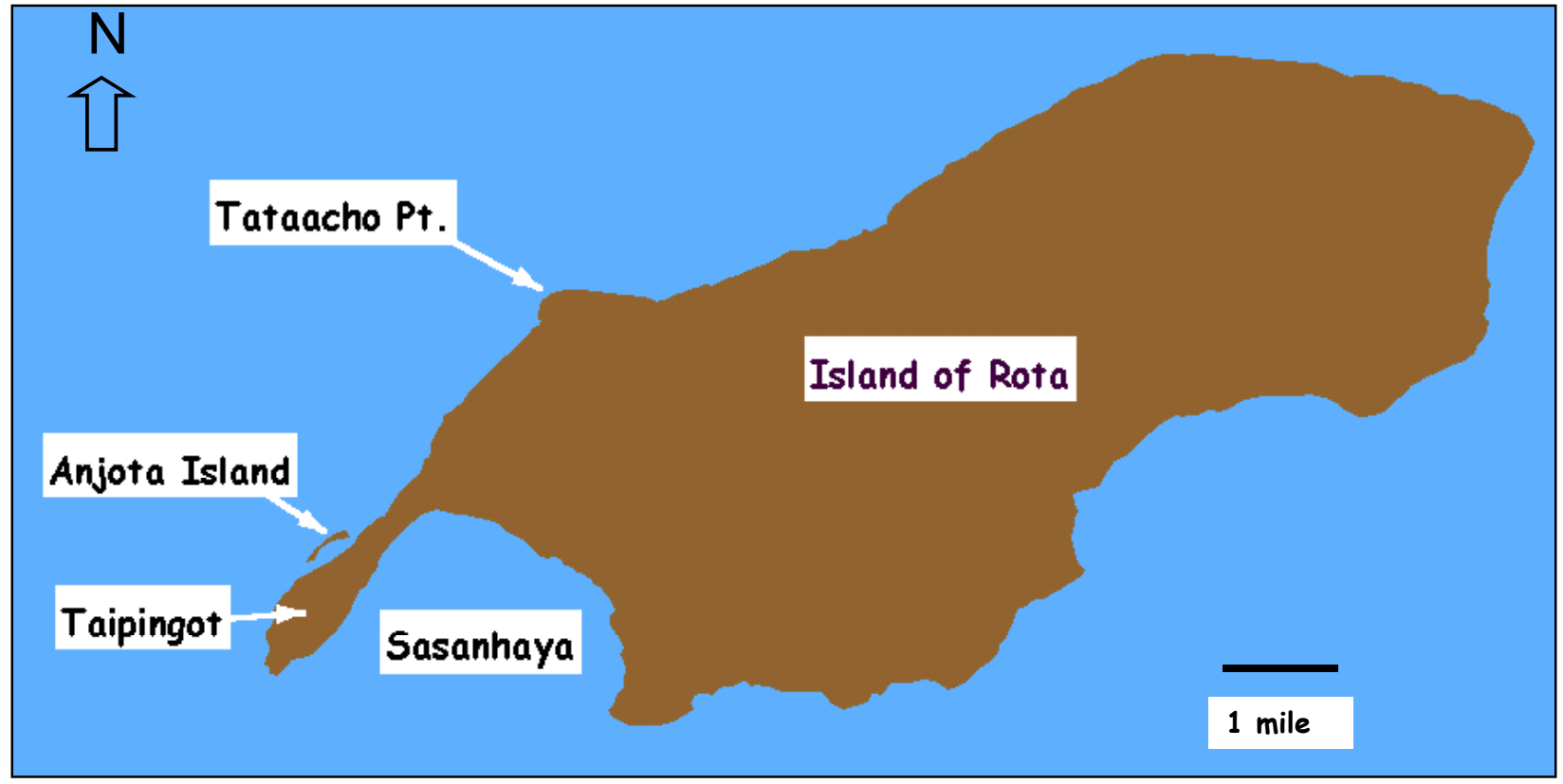

Figure 2. Location map, island of Rota

Rota's low-latitude location is favorable for tropical storm and typhoon formation and passage. The island often experiences typhoon impacts and occasionally a typhoon passes directly over the island. Typical typhoon impacts include wind and rainfall damage to buildings, roads, and crops; and coastal damage due to high waves and water levels. For example, in November and December 1997, two super typhoons (Keith and Paka) brushed across Rota in close succession, causing major damage.

In support of its mission, the U.S. Federal Emergency Management Agency (FEMA) funded the U.S. Army Engineer District, Honolulu, to conduct a flood insurance study for the island of Rota. The Honolulu District funded the 
U.S. Army Engineer Research and Development Center, Coastal and Hydraulics Laboratory (CHL), to analyze typhoon-induced coastal inundation to assist in delineating flood-prone areas. CHL's study task was to calculate stagefrequency relationships for representative shore-perpendicular transects in the study area. This report documents procedures and results from the CHL study. The study area consists of two stretches of coast encompassing the vulnerable population and road areas of the island (Figure 3). One stretch is located inside Sasanhaya embayment, covering a 3.4-km (2.1-mile) length of coast. The other stretch extends from the west side of Taipingot peninsula up to Tataacho Point and then continues east and northeast to a mid-island longitude where the coastal road turns inland. This stretch is $10.9 \mathrm{~km}$ (6.8 miles) long.

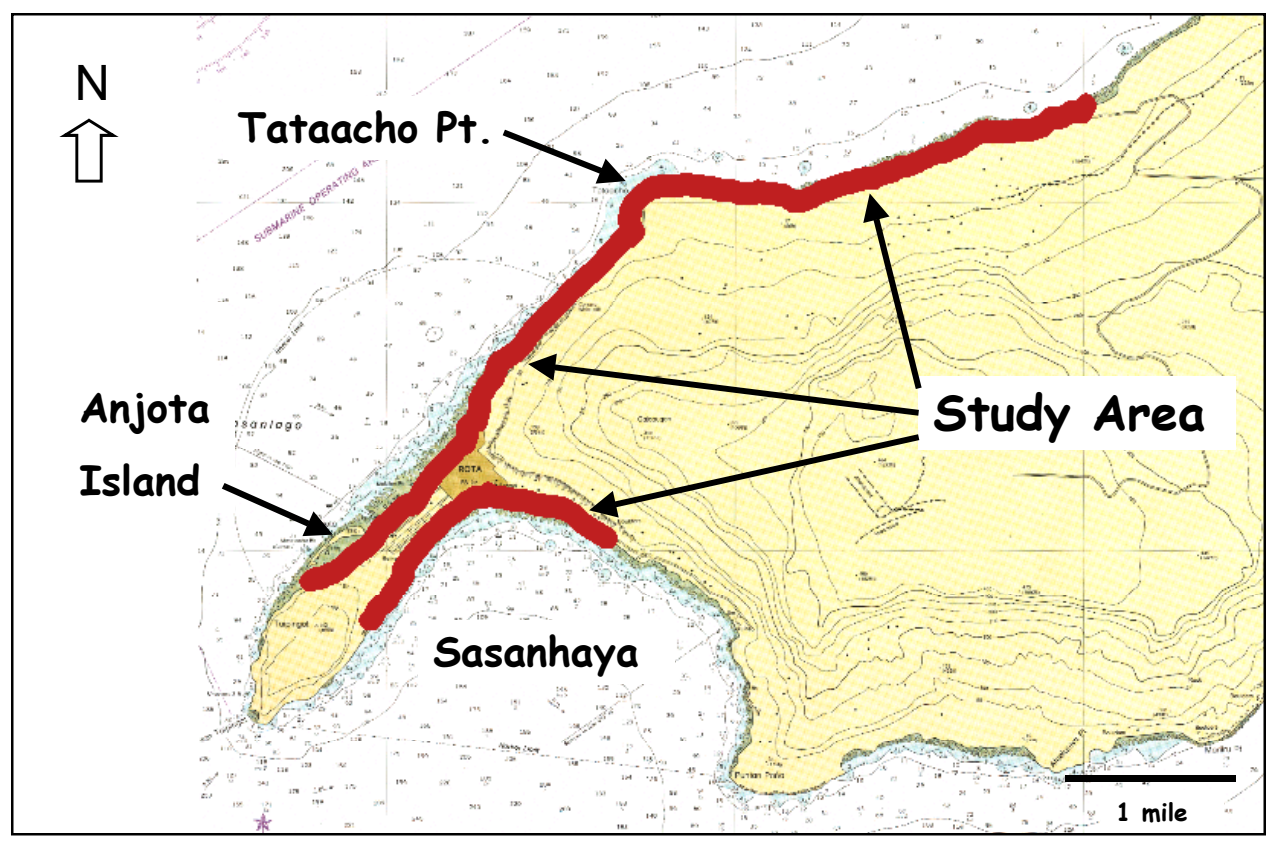

Figure 3. Study area

This report describes the procedures and results of the typhoon stagefrequency analysis for the study area coastline of Rota. Many of the techniques employed in this study have been successfully applied in previous stagefrequency analyses (Mark 1996; Mark and Scheffner 1997; Militello, Scheffner, and Thompson 2003). Another closely related CHL study evaluated overtopping rates rather than water levels along an exposed coast adjacent to the commercial port road at Apra Harbor, Guam (Thompson and Scheffner 2002). Because Apra Harbor and Rota are relatively close geographically and the time frame for the two studies coincided, some efforts benefitted both studies and helped reduce study costs.

The analysis for this study consisted of five tasks. The first task was development of a typhoon database for the western Pacific Ocean and analysis of storm statistics and correlations. Storms impacting the study area were selected from the database to create a smaller, representative group of storms called the training set. A planetary boundary layer model was applied to calculate wind and atmospheric pressure fields for each storm in the training set. 
The second task consisted of simulation of storm surge by application of a long-wave, finite-element hydrodynamic model. For each storm in the training set, storm surge was calculated at selected sites in the study area. The third task consisted of wave parameter calculation for each storm by application of a wave growth/propagation model and a nearshore wave-transformation model. The fourth task consisted of time-series calculation of ponding level, setup, and runup for each storm. These calculations were performed for profiles specified by the Honolulu District.

The fifth task was the development of frequency-of-occurrence relationships for water levels along the study coasts. These relationships were developed by application of the Empirical Simulation Technique (EST) to relate typhoon parameters and corresponding storm water levels. The EST is a statistical resampling procedure that applies historical data to develop joint probability relationships among the various measured storm parameters (e.g., maximum wind speed). The resampling scheme generates large populations of data that are statistically similar to a much smaller database of historical events, i.e. the training set of storms. Application of the EST to the expanded storm set produces a database of peak water levels by repeatedly simulating multiple-year periods (e.g., 200-year periods) of storm activity. Expected stage-frequency relationships are then calculated from the database of peak storm-induced water levels. Because of the repeated simulations, a measure of expected variability of calculated stage-frequency relationships is also provided.

This report is divided into six chapters. Following the introduction, Chapter 2 describes selection of storms to be modeled. Chapter 3 describes key models and methods used in the study including meteorological, wave, and longwave hydrodynamic models, nearshore analysis, and EST. Chapter 4 discusses long-wave hydrodynamic model calibration, validation, and implementation. Chapter 5 reviews the methods as applied in this study for calculation of stagefrequency relationships and presents study results. Chapter 6 provides summary and conclusions of the study. References are listed after Chapter 6.

Appendices follow the main report. Appendix A shows tracks followed by typhoons selected for modeling. Appendix B contains a listing of station locations for storm surge calculations. Corresponding topographic profile numbers are given in Appendix C. Appendices D and E give stage-frequency relationship tables and plots, respectively. Appendix F contains tables of wave parameters, peak water levels, and water level components corresponding to peak water level in each modeled storm for selected profiles. 


\section{Storm Selection}

This chapter describes typhoons selected for modeling and the procedures used for selection. The objective was to develop a set of approximately 30 typhoons which are representative of storms affecting flooding along the study area coasts of Rota. Coincidental, a similar study of flooding along a coast of Apra Harbor, Guam, was ongoing at the time of this study (Thompson and Scheffner 2002). The two islands are sufficiently close together that they are affected by the same storms. One historical storm data set served the needs of both studies.

The database of historical typhoons in the western Pacific is available on the internet through the U.S. Navy's Joint Typhoon Warning Center (JTWC), http://www.npmoc.navy.mil/products/jtwc/best_tracks. Typhoon track data covering the years 1945-97 were used. Track data are given at 6-hour intervals, including latitude and longitude of the storm eye (with 0.1-deg precision) and maximum sustained 1-min mean surface wind, in knots. Western Pacific storms are identified with prefix $B W P$ followed by a four-digit number: the first two digits give sequential storm number for the year $(01$ is the first western Pacific storm for the year, etc.) and the second two digits give the year. For example, Typhoon Pamela (BWP0676) was the sixth western Pacific typhoon during the year 1976. These four-digit numbers are used as storm identifiers in the present study. Tropical storms originating outside the western Pacific which may affect the study area have other prefix identifiers. These other possibilities were considered, but the only such storm important in this study was Paka (BCP0597), indicating it originated in the central Pacific.

Available information about storm impacts on Rota and Guam was also gathered and reviewed to insure the storm selection process included all important historical storm events. Sources included JTWC (1991) and JTWC annual and special storm reports. This review resulted in elimination of one typhoon (Querida 1246) from consideration because the best track data differed significantly from the published description of storm track relative to Guam and Rota. Subsequent discussions with JTWC indicated that storms from before 1959 in the present data set should be considered less reliable. Other than Querida, pre-1959 storms were retained for modeling consideration because there were no inconsistencies evident in the best track files and it was desirable to preserve the full 53-year historical database.

Only typhoons that passed within a $322-\mathrm{km}$ (200-mile) square box centered on the islands of Rota and Guam and had wind speeds of 64 knots (typhoon 
strength) or greater within the box were considered. From these typhoons, the following considerations were applied to select a storm set for modeling. Tracks for the selected typhoons are shown in Appendix A.

Strong and weak typhoon pairs. Typhoons typically approach Rota from the east, continue moving toward the west past the island, and eventually curve toward the northwest. A small number of typhoons have approached from the south and continued moving northward past the island. Historical typhoons have no evident preference for passing on one particular side of the island and occasionally they pass directly across the island. A representative set of six strong and weak typhoon pairs (12 storms) was selected for the following cases, based on analysis of the types of tracks and storms:

a. West-moving, far north of islands.

b. West-moving, near north of islands.

c. West-moving, near south of islands.

d. West-moving, far south of islands.

e. North-moving, west of islands.

f. North-moving, east of islands.

Typhoons passing near islands. All remaining typhoons that passed close to the islands (basically between Rota and Guam or across either island) were selected, a total of 14 storms. These storms were considered potentially damaging because of their proximity to Rota.

Additional typhoons. The preceding criteria give a relatively complete and representative set of historical storms affecting Rota. Several other typhoons, not chosen initially by the criteria, were also reviewed to insure that all historically damaging storms were considered. These included three other candidate strong storms for "West-moving, far north of islands," and a few other typhoons with unusual tracks and some potential for generating wave and flooding impacts on Rota and/or Apra Harbor. JTWC annual reports and storm reports were consulted to see if any of these storms caused notable wave and flooding damage. Based on these considerations, two additional typhoons were added to the model set, giving a total of 28 storms.

Extreme typhoons. The impact of a typhoon on the study area at Rota can be strongly affected by typhoon track. Historical data provide a valuable record, but storms with small variations in the historical tracks would have been equally likely. For analysis of extremes, it is important to capture small variations in the most damaging storms that would have caused them to be more damaging to the study area. These are referred to as hypothetical storms.

Two historical storms were considered with altered tracks to develop hypothetical cases to complete the storm data set: Gilda (3367) and Olive (0163). Gilda's historical track past Rota was toward west northwest, with the 
eye slicing directly across the island's midsection. Olive's historical track was west of Guam and Rota, moving toward the north with a slight curve toward northeast. Several hypothetical variations in Gilda were studied, with track shifted slightly north and south of the actual track. Gilda with track shifted north by $20 \mathrm{~km}$ (12.7 miles) created larger waves offshore from some of the study area coasts than the historical Gilda or any other historical typhoon modeled. Thus, a hypothetical typhoon consisting of Gilda with track shifted $20 \mathrm{~km}$ (12.7 miles) north was added to the model set.

Olive with track shifted 0.67 deg toward the east swept through Sasanhaya embayment and across Rota and had a major impact on offshore waves approaching that study area. It was added to the storm set for modeling.

For statistical balance in the modeled storm set, two additional hypothetical typhoons were added to the model set, representing Gilda with track shifted $20 \mathrm{~km}$ (12.7 miles) south and Olive with track shifted $0.67 \mathrm{deg}$ to the west. In the EST analysis, each storm in a trio of hypothetical storms and associated historical storm is given one-third the weighting of other historical storms to preserve the historical frequency-of-occurrence statistics.

With the addition of two hypothetical storms and their shifted tracks, the final data set for modeling contained a total of 32 storms. The storms are listed in Table 1. Storm numbers used for hypothetical storms are similar to the historical storm number on which they are based, but the first digit is changed as a key identifying the hypothetical variation.

Statistical Representativeness. Typhoons selected for modeling should be fairly representative of storm track statistics for the full set of typhoons passing into the box around Rota and Guam. Typhoons were classified according to their travel direction, and results are given in Table 2. Hypothetical storms are not included in these statistics. The storms selected for modeling are considered sufficiently representative of the full set of storms. 


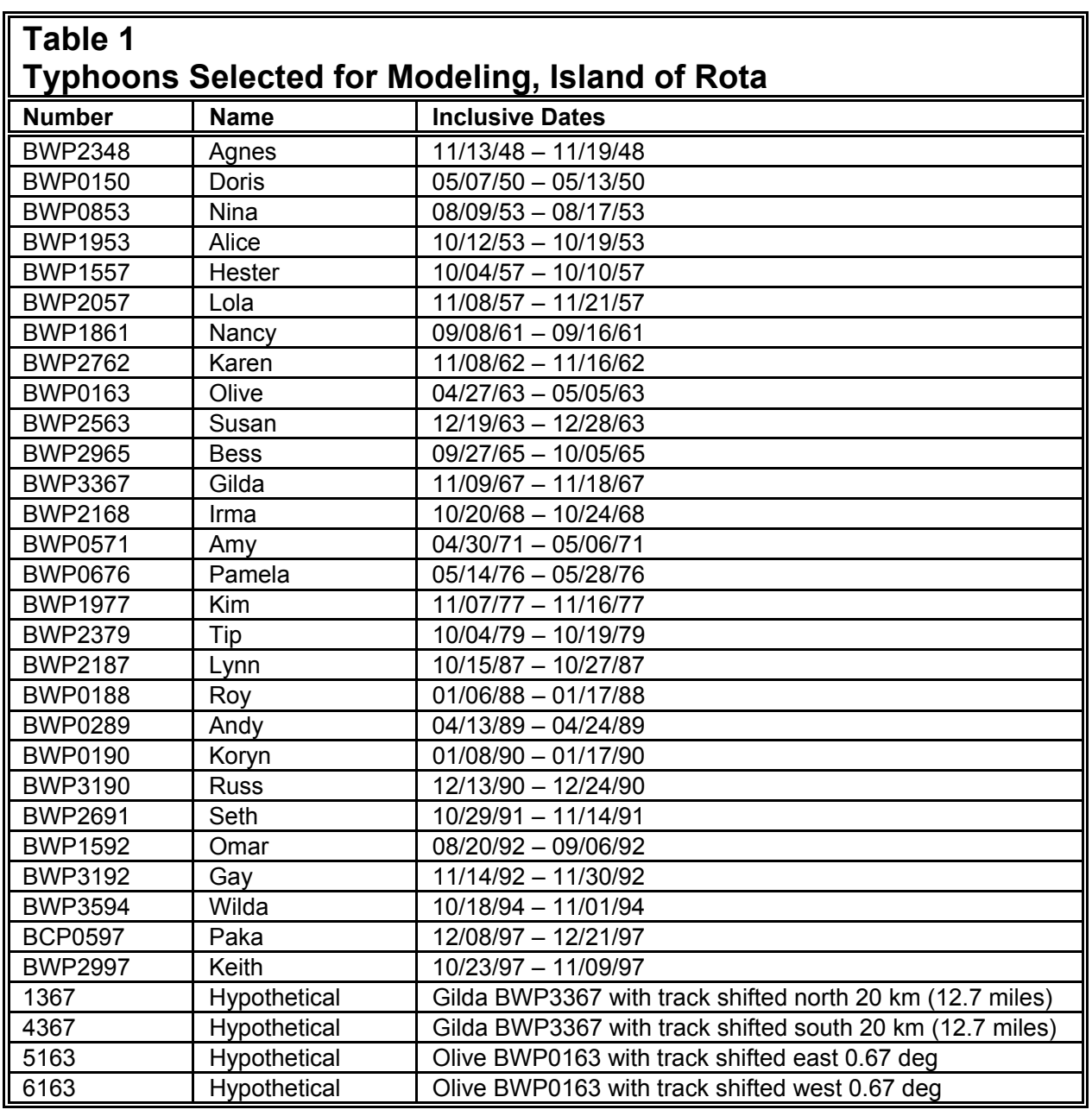

\section{Table 2}

Statistics of Typhoon Travel Direction

\begin{tabular}{||l|l|l|l|l||}
\hline \multirow{2}{*}{ Travel Direction } & \multicolumn{2}{|l|}{ Full Set of Storms } & \multicolumn{2}{l||}{ Storms Selected for Modeling } \\
\cline { 2 - 5 } & $\begin{array}{l}\text { Number of } \\
\text { Storms }\end{array}$ & Percent & Number of Storms & Percent \\
\hline \hline Moving toward west & 75 & 65 & 18 & 64 \\
\hline Moving toward north & 27 & 23 & 6 & 21 \\
\hline $\begin{array}{l}\text { Moving toward west \& then } \\
\text { north }\end{array}$ & 11 & 9 & 3 & 11 \\
\hline Moving toward east & 3 & 3 & 1 & 4 \\
\hline Total & 116 & 100 & 28 & 100 \\
\hline \hline
\end{tabular}




\section{Modeling Approach}

Calculation of typhoon stage-frequency relationships for study area coasts along the island of Rota requires application of several standard CHL numerical models and many additional processing steps. The objective of this chapter is to explain the modeling approach and document models and procedures used in the study. An overview of the modeling approach is given in the following paragraphs. More detailed descriptions of key modeling steps are given in following sections of the chapter.

The main modeling steps are as follows. First, a Planetary Boundary Layer (PBL) wind model simulates the time-history of typhoon-induced wind and atmospheric pressure fields for each selected storm during its general proximity to the study area. The time-history of wind information serves as input to both a long-wave hydrodynamic model ADCIRC and a wind-wave model WISWAVE. The ADCIRC model provides a refined time-history of typhoon-induced water levels at the study location for each storm. The WISWAVE model provides a time-history of deepwater wave parameters in the general vicinity of Rota coasts.

For the study areas, including the south-facing Sasanhaya embayment coast and the northwest- and west-facing exposed coasts, WISWAVE information from an appropriate offshore grid point is adjusted to provide a time-history of waves incident to the nearshore coral reef. The adjustment is done with the wave-transformation model WAVTRAN. These wave parameters are subsequently matched in time with nearshore water level information from ADCIRC and used to calculate a time-history of wave ponding over the reef and nearshore setup and runup. Maximum water level is extracted for each nearshore profile in each storm. The EST analysis is applied and water levels are calculated for various return periods.

\section{Wind and Atmospheric Pressure Field Model}

The PBL numerical model was used for simulation of typhoon-generated wind and atmospheric pressure fields. The model applies vertically averaged primitive equations of motion for predicting tropical storm wind velocities. The model includes parameterization of momentum, heat, and moisture fluxes together with surface drag and roughness formulations. Through hindcast applications, Cardone, Greenwood, and Greenwood (1992) found that the PBL model calculates accurate surface wind speeds and directions as compared to measurements collected in tropical storms over open water. 
The PBL model requires a set of storm parameter snapshots for input. The snapshots consist of meteorological storm parameters that define the storm at various stages in its development or at particular times during its life. These parameters include: latitude and longitude of the storm's eye; track direction and forward speed measured at the eye; radius to maximum winds; central and peripheral atmospheric pressures; and an estimate of the geostrophic wind speed and direction. Also, the direction and speed of steering currents can be provided for representing asymmetric storms.

Storm tracks and maximum sustained 1-min mean surface winds were obtained from the JTWC database described in Chapter 2. Information contained in this database is provided at 0000, 0600, 1200, and $1800 \mathrm{hr}$ Greenwich Mean Time (GMT). The JTWC storm files were preprocessed to put them into the required snapshot format and to estimate other necessary parameters. Central pressure was calculated from maximum sustained 1-min mean surface wind speed using the relationship developed by Atkinson and Holliday (1977), based on data from Guam

$$
W=6.7\left(P_{a}-P_{c}\right)^{0.644}
$$

where

$$
\begin{aligned}
& W=\text { maximum sustained } 1 \text {-min mean surface wind speed in knots } \\
& P_{a}=\text { ambient pressure in } \mathrm{mb} \\
& P_{c}=\text { central pressure in } \mathrm{mb}
\end{aligned}
$$

Ambient pressure is taken to be $1,010 \mathrm{mb}$, in accordance with Atkinson and Holliday's (1977) recommendation for the western North Pacific area.

Radius to maximum winds (RMW) is approximated by application of relationships developed in a generalized numerical model study of storm characteristics (Jelesnianski and Taylor 1973). The RMW is based on $W$ and the central pressure deficit, $P_{a}-P_{c}$. Track directions and forward speeds required by the PBL model are approximated by cubic spline interpolation at hourly intervals from 6-hr coordinate positions provided in the database. Geostrophic wind speeds were specified as $6 \mathrm{~m} / \mathrm{s}$.

The spatial area covered by a tropical storm at a given time is specified in the PBL model to correspond to a set of nodes on a numerical grid. Wind velocities and atmospheric pressure values are computed at each node in the grid. Whereas some models employ a fixed grid system to simulate a tropical storm (i.e., stationary grid with a moving storm), the PBL model simulates a typhoon as a stationary storm with a moving grid. Forward motion of the storm is calculated as the vector sum of the forward and rotational velocity vector components. The numerical grid is moved with the storm at the calculated forward velocity at each time-step so that the grid center always coincides with the storm center. 
The distribution of wind speed and radial change in wind speed varies spatially within a tropical storm such that higher spatial resolution of the wind field is required in the central region of the storm, whereas coarser resolution suffices on the outer areas. To provide spatially-graded resolution of the wind field, a nested gridding technique is applied consisting of five layers or subgrids. The grid nesting is applied such that all subgrids contain the same number of nodes, however, the spatial coverage and resolution differs and is successively graded. Each subgrid is composed of 21 by 21 nodes in the $\mathrm{x}$ - and $\mathrm{y}$-directions, respectively. The centers of all subgrids lie on node $(11,11)$, defined at the eye of the tropical storm. For this study, the subgrid with the finest resolution had an incremental distance of $5 \mathrm{~km}$ (3.1 miles) between nodes and covered an area of $10,000 \mathrm{sq} \mathrm{km}(3,861$ square miles). Incremental distances for the remaining subgrids were $10,20,40$, and $80 \mathrm{~km}(6.2,12.4,24.9$, and 49.7 miles $)$ and their areas of coverage were $40,000,160,000,640,000$, and 2,560,000 sq km $(15,444$, $61,776,247,104$, and 988,428 square miles), respectively.

For each snapshot, the equations of motion are first solved for the subgrid covering the greatest area. Computed wind velocities are then applied as boundary conditions on the second-largest grid, and the equations are solved again. This procedure is followed for the remaining grids where wind fields are computed on successively smaller grids. Thus, the nested grid technique provides wind field information over a wide spatial area while sufficient grid resolution is provided to accurately compute winds in the vicinity of the tropical storm eye.

After all snapshots have been processed, hourly wind and atmospheric pressure fields are interpolated using a nonlinear blending algorithm which produces a smooth transition from one snapshot to the next. Hourly wind and pressure fields are then interpolated from the PBL grid onto the hydrodynamic or wave model grid and subsequently stored for use by those models. Wind velocities produced by the PBL model represent an averaging time of 30-60 min, which is appropriate for wave and storm surge modeling (Thompson and Cardone 1996).

\section{Storm Surge Model}

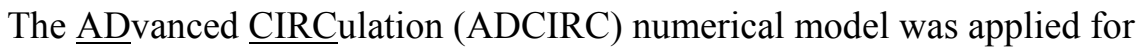
simulation of long-wave hydrodynamic processes in the study area. The model calculates a two-dimensional (2-D), depth-integrated finite-element solution of the Generalized Wave-Continuity Equation (GWCE). Fundamental components of the GWCE are the depth-integrated continuity and Navier-Stokes equations for conservation of mass and momentum. The assumption of incompressibility and the Boussinesq and hydrostatic pressure approximations were applied. The primitive, nonconservative form of the governing equations, given in spherical coordinates, as applied in the model are (Flather 1988; Kolar et al. 1993)

$$
\frac{\partial \zeta}{\partial t}+\frac{1}{R \cos (\phi)}\left[\frac{\partial U D}{\partial \varphi}+\frac{\partial(U V \cos (\phi))}{\partial \phi}\right]=0
$$




$$
\begin{aligned}
& \frac{\partial U}{\partial t}+\frac{1}{R \cos (\phi)} U \frac{\partial U}{\partial \varphi}+\frac{1}{R} V \frac{\partial U}{\partial \phi}-\left[\frac{\tan (\phi)}{R} U+f\right] V \\
& =-\frac{1}{R \cos (\phi)} \frac{\partial}{\partial \varphi}\left[\frac{P_{S}}{\rho_{0}}+g(\zeta-\alpha \xi)\right]+\frac{\tau_{S \varphi}}{\rho_{0} D}-\tau_{*} U \\
& \frac{\partial V}{\partial t}+\frac{1}{R \cos (\phi)} U \frac{\partial V}{\partial \varphi}+\frac{1}{R} V \frac{\partial V}{\partial \phi}-\left[\frac{\tan (\phi)}{R} U+f\right] U \\
& =-\frac{1}{R \cos (\phi)} \frac{\partial}{\partial \phi}\left[\frac{P_{S}}{\rho_{0}}+g(\zeta-\alpha \xi)\right]+\frac{\tau_{S \phi}}{\rho_{0} D}-\tau_{*} V
\end{aligned}
$$

where

$$
\begin{aligned}
& t=\text { time } \\
& \varphi=\text { degrees longitude (east of Greenwich is taken positive) } \\
& \phi=\text { degrees latitude (north of the equator is taken positive) } \\
& \zeta=\text { free-surface elevation relative to the geoid } \\
& U=\text { depth-averaged velocity component parallel to the } \\
& \text { east-west axis } \\
& V=\text { depth-averaged velocity component parallel to the } \\
& \text { north-south axis } \\
& R=\text { radius of the earth } \\
& D=\zeta+h=\text { total water-column depth, } h \text { is the bathymetric depth } \\
& \text { relative to the geoid } \\
& f=2 \Omega \sin (\phi)=\text { Coriolis parameter, } \Omega \text { is the angular speed of the } \\
& \text { earth's rotation } \\
& P_{S}=\text { atmospheric pressure at the free surface } \\
& g=\text { acceleration due to gravity } \\
& \alpha \xi=\text { effective Newtonian equilibrium tide potential } \\
& \rho_{0}=\text { reference density of water } \\
& \tau_{S \varphi} \text { and } \tau_{S \phi}=\text { applied free-surface stresses } \\
& \tau_{*}=\text { bottom stress given by } C_{f}\left(U^{2}+V^{2}\right)^{1 / 2} / D \text { where } C_{f} \\
& \text { is the bottom-friction coefficient }
\end{aligned}
$$


The time-differentiated form of the conservation of mass equation is combined with a space-differentiated form of the conservation of momentum equation to develop the GWCE (Westerink et al. 1992) given by

$$
\begin{aligned}
& \frac{\partial^{2} \zeta}{\partial t^{2}}+\tau_{0} \frac{\partial \zeta}{\partial t}-\frac{1}{R \cos (\phi)} \frac{\partial}{\partial \varphi}\left\{\frac{1}{R \cos (\phi)}\left[\frac{\partial(D U U)}{\partial \varphi}+\frac{\partial(D U V \cos (\phi))}{\partial \phi}\right]-U V D \frac{\tan (\phi)}{R}\right\} \\
& \left\{-2 \Omega \sin (\phi) D V+\frac{D}{R \cos (\phi)} \frac{\partial}{\partial \varphi}\left[g(\zeta-\alpha \xi)+\frac{P_{S}}{\rho_{0}}\right]+\tau_{*} D U-\tau_{0} D U-\frac{\tau_{S \varphi}}{\rho_{0}}\right\} \\
& -\frac{1}{R} \frac{\partial}{\partial \phi}\left\{\frac{1}{R \cos (\phi)}\left[\frac{\partial D V V}{\partial \varphi}+\frac{\partial D V V \cos (\phi)}{\partial \phi}\right]+U U D \frac{\tan (\phi)}{R}+2 \Omega \sin (\phi) D U\right\} \\
& -\frac{1}{R} \frac{\partial}{\partial \phi}\left\{\frac{D}{R} \frac{\partial}{\partial \phi}\left[g(\zeta-\alpha \xi)+\frac{P_{S}}{\rho_{0}}\right]+\left(\tau_{*}-\tau_{0}\right) D V-\frac{\tau_{S \phi}}{\rho_{0}}\right\} \\
& -\frac{\partial}{\partial t}\left[\frac{V D}{R} \tan (\phi)\right]-\tau_{0}\left[\frac{V D}{R} \tan (\phi)\right]=0
\end{aligned}
$$

The coefficient $\tau_{0}$ represents a GWCE weighting function that permits solution behavior to have characteristics between those of the primitive equation and the pure wave equation. The ADCIRC model solves the GWCE (Equation 5) in conjunction with the primitive momentum equations given by Equations 3 and 4.

The GWCE-based solution scheme eliminates several problems associated with finite-element models that solve the primitive forms of the continuity and momentum equations (i.e., Navier-Stokes equations), including spurious modes of oscillation and artificial damping of the tidal signal. Forcing functions include time-varying water-surface elevation, wind stress, atmospheric pressure, and the Coriolis effect.

The computational grid developed for this study is a large-domain circular grid with a radius of $4 \mathrm{deg}$ (276 miles) and center at long. $145^{\circ} \mathrm{E}$ and lat. $14^{\circ} \mathrm{N}$. The islands of Rota and Guam are located in the central region of the grid. The large scale of the grid has two main advantages. First, the tidal forcing boundaries are far from the region of interest such that island shorelines are free from boundary effects. Second, because typhoons are large-scale atmospheric phenomena, a large-domain grid is preferred to maximize the interaction of the horizontal storm area with the computational grid, as well as the storm track.

The grid developed for this study is shown in Figure 4. Grid resolution is coarser in the open regions with increasing resolution toward the shore. Grid parameters and range of scale of element sizes contained in the grid are given in Table 3. Two Mariana Islands north of Rota were sufficiently large and close that they are included in the grid: Saipan and Tinian. The grid around these islands was specified to be much coarser than the region surrounding Rota. Grid resolution around Guam was also relatively coarse in comparison to the recent Apra Harbor study (Thompson and Scheffner 2002). 


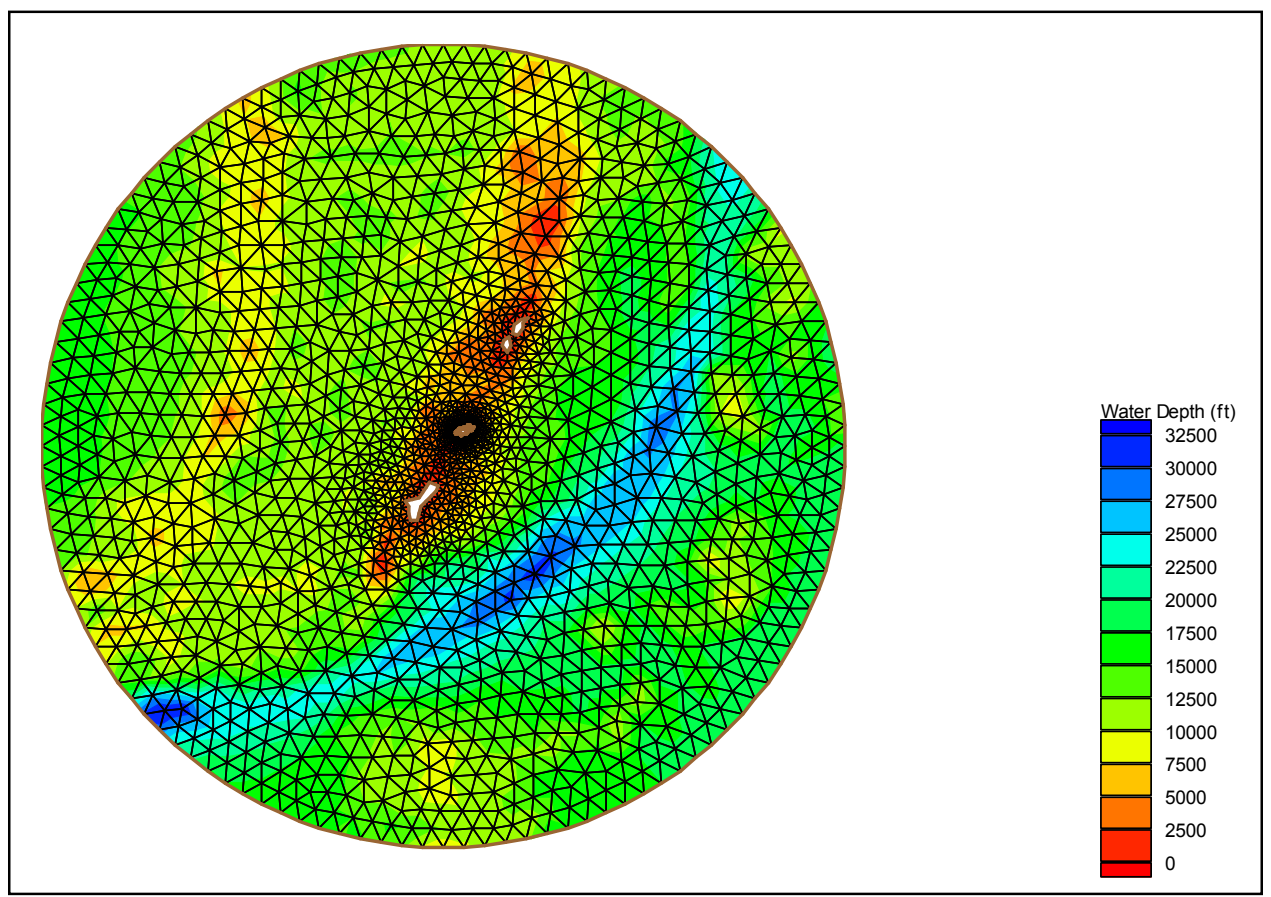

Figure 4. Complete computational grid for Rota study

\begin{tabular}{|c|c|}
\hline Parameter & Value \\
\hline Maximum element area & $\begin{array}{l}462,087,758 \mathrm{~m}^{2}\left(4,973,750,272 \mathrm{ft}^{2}\right) \\
\end{array}$ \\
\hline Minimum element area & $3,112 \mathrm{~m}^{2}\left(33,494 \mathrm{ft}^{2}\right)$ \\
\hline Ratio of maximum to minimum element areas & 148,497 \\
\hline Number of elements & 7,983 \\
\hline Number of nodes & 4,315 \\
\hline Center longitude and latitude & $145 \mathrm{E}, 14 \mathrm{~N}$ \\
\hline Circular grid radius & $4 \mathrm{deg}$ \\
\hline
\end{tabular}

The finest grid resolution is around the study area. Reefs, shallow areas, and embayments are finely resolved in and near the study area so that the hydrodynamics can be accurately calculated in these regions. Details of the grid around Rota are shown in Figure 5. Figure 6 shows detail of the study area. Because of the fine grid resolution in reef areas coupled with the extreme hydrodynamic conditions (strong currents and rapid change in water level) associated with the storms, a time-step of $5 \mathrm{sec}$ was required for model runs.

Several data sources were accessed for development of the computational grid. Initially, shoreline and bathymetry data were obtained from the U.S. Department of Defense Digital Nautical Chart database (National Imagery and Mapping Agency (NIMA) 1999). The digital database was supplemented in offshore areas by digitizing points and contours from National Oceanic and Atmospheric Administration (NOAA) Chart \#81004 and DMA Chart \#81025 as needed to get a complete representation. The Rota island boundary and coastal bathymetry, which were absent from the NIMA database, were digitized from 


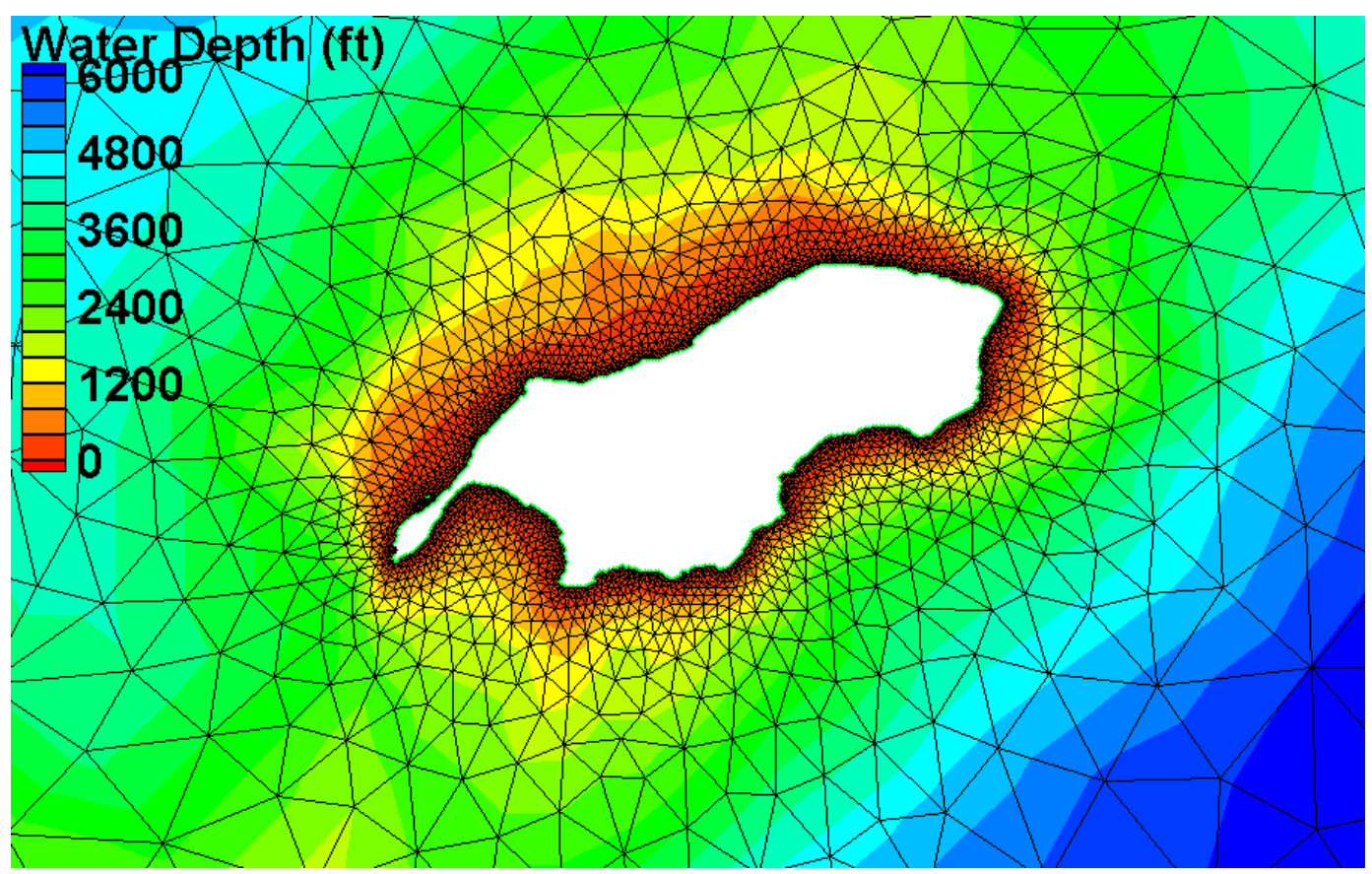

Figure 5. Computational grid showing detail for Rota

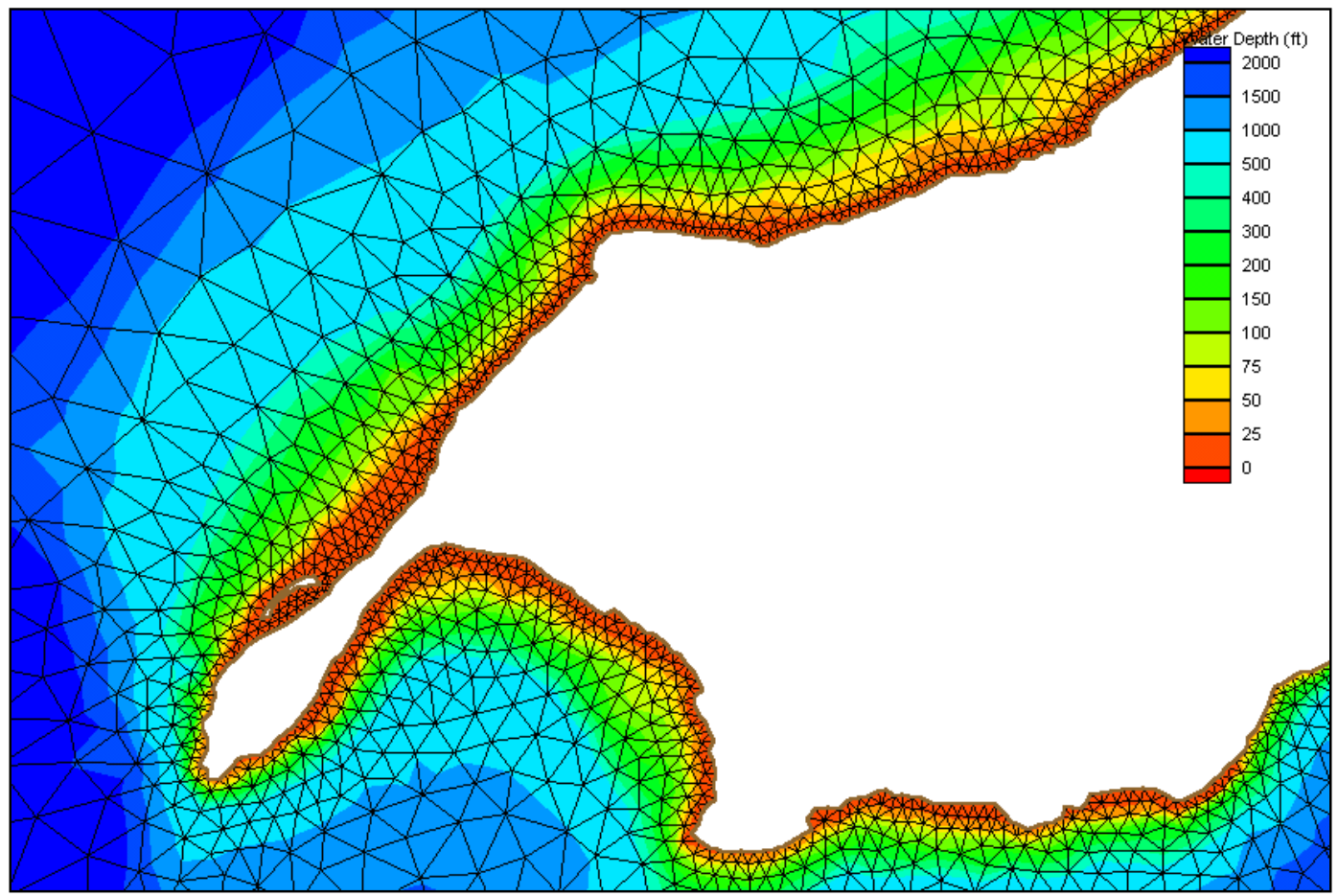

Figure 6. Computational grid showing detail for study area 
NOAA Chart \#81063. Bathymetry around Guam was supplemented using

NOAA Chart \#81048. Grid depths are referenced to mean sea level (msl).

Tidal elevations specified at the open-water boundary were calculated from tidal amplitudes and phases contained in the LeProvost World Tidal Constituent Database, which provides constituent data at 1-deg increments in latitude and longitude. A bilinear interpolation algorithm was applied to calculate tidal amplitudes and phases at 118 open boundary nodes. The six tidal constituents applied at the open boundaries were: $\mathrm{M}_{2}, \mathrm{~S}_{2}, \mathrm{~N}_{2}, \mathrm{P}_{1}, \mathrm{O}_{1}$, and $\mathrm{K}_{1}$.

\section{Wave and Wave Transformation Models}

Deepwater wave fields were calculated by application of the Wave Information Studies Wave (WISWAVE) model (Hubertz 1992; Resio and Perrie 1989). This model is a second-generation discrete directional spectral wave model in which the spectral wave computations are based on the integration of energy over the discrete frequency spectrum. Model output includes time series of significant wave height, peak (dominant) or mean wave period, and mean wave direction. Peak period is defined as the period associated with the mid-band frequency, or that frequency band containing the largest spectral energy density. Mean wave period is an energy-weighted quantity integrated over all user-specified frequencies of interest. Model input includes a rectilinear computational grid, with water depths specified at each node, and wind speed and direction over the grid domain.

Application of the wave model required a grid resolution such that calculation points could be distributed around and near to the coasts of Rota and Guam so that representative wave conditions would be captured for all sides of the islands needed in the studies. To meet this requirement, a grid with constant spacing of $0.083 \mathrm{deg}$ was developed. For wave modeling at this scale, deep water can be applied over the grid. The islands of Rota and Guam were specified as land in the grid for accurate calculation of wave sheltering and refraction. At this grid scale, Rota is represented by 6 land points and Guam by 22 land points. Details of the grid are given in Table 4.

\begin{tabular}{|l|l||}
\hline \multicolumn{2}{|l||}{\begin{tabular}{l|} 
Table 4 \\
WISWAVE Grid Parameters
\end{tabular}} \\
\hline \hline Parameter & Value \\
\hline \hline Longitude limits & $141.0333 \mathrm{E}, 149.0333 \mathrm{E}$ \\
\hline Latitude limits & $10.0333 \mathrm{~N}, 18.0333 \mathrm{~N}$ \\
\hline Cell side length & $0.083 \mathrm{deg}$ \\
\hline Total number of nodes & 9409 \\
\hline Number of nodes in north-south direction & 97 \\
\hline Number of nodes in east-west direction & 97 \\
\hline
\end{tabular}

Wind forcing for the wave model was calculated by application of the PBL model, as discussed previously. Wind speed and direction were calculated for each point on the wave grid at 1 -hr intervals. 
Deepwater wave parameters calculated by the wave model were stored at 24 stations surrounding Rota and eight stations around Apra Harbor and the west coast of Guam for each of the 32 storms in the training set (described in Chapter 2). A list of these stations is given in Table 5. The deepwater wave stations are well offshore on a coarse grid pattern rather than the detailed storm surge grid pattern described previously. The duration of wave simulations corresponded to the time coverage of each storm in the JTWC database. Thus, each storm simulation began when the storm center was well outside the WISWAVE grid and ended with the storm cell well beyond the grid. Wave parameters were stored at 1-hr intervals.

\begin{tabular}{|c|c|c|}
\hline \multicolumn{3}{|c|}{$\begin{array}{l}\text { Table } 5 \\
\text { Deepwater Wave Stations }\end{array}$} \\
\hline Station Number & Latitude, deg N & Longitude, deg $\mathrm{E}$ \\
\hline 1 & 13.37 & 144.45 \\
\hline 2 & 13.45 & 144.45 \\
\hline 3 & 13.53 & 144.45 \\
\hline 4 & 13.45 & 144.53 \\
\hline 5 & 13.53 & 144.53 \\
\hline 6 & 13.62 & 144.53 \\
\hline 7 & 13.53 & 144.62 \\
\hline 8 & 13.62 & 144.62 \\
\hline 9 & 14.12 & 144.95 \\
\hline 10 & 14.20 & 144.95 \\
\hline 11 & 14.03 & 145.03 \\
\hline 12 & 14.12 & 145.03 \\
\hline 13 & 14.20 & 145.03 \\
\hline 14 & 14.28 & 145.03 \\
\hline 15 & 13.95 & 145.12 \\
\hline 16 & 14.03 & 145.12 \\
\hline 17 & 14.28 & 145.12 \\
\hline 18 & 14.37 & 145.12 \\
\hline 19 & 13.95 & 145.20 \\
\hline 20 & 14.03 & 145.20 \\
\hline 21 & 14.28 & 145.20 \\
\hline 22 & 14.37 & 145.20 \\
\hline 23 & 13.95 & 145.28 \\
\hline 24 & 14.03 & 145.28 \\
\hline 25 & 14.28 & 145.28 \\
\hline 26 & 14.37 & 145.28 \\
\hline 27 & 14.03 & 145.37 \\
\hline 28 & 14.12 & 145.37 \\
\hline 29 & 14.20 & 145.37 \\
\hline 30 & 14.28 & 145.37 \\
\hline 31 & 14.12 & 145.45 \\
\hline 32 & 14.20 & 145.45 \\
\hline
\end{tabular}

Deepwater waves produced by WISWAVE were transformed to the study area by application of the nearshore wave transformation model WAVTRAN (Jensen 1983; Gravens, Kraus, and Hanson 1991). The WAVTRAN model calculates spectral transformation of waves during propagation from one depth to another shallower depth, taking into account shoreline orientation and wave sheltering. The model assumes that sea and swell waves have an energy spectrum that follows the Texel, MARSEN, ARSLOE (TMA) spectral form (Bouws et al. 1985). Directional spread is calculated by 4th and 8th power cosine functions. Wave transformation calculation is dependent on the shoreline orientation 
because bottom contours are assumed parallel to the shoreline. If wave sheltering is included, wave energy coming from directions specified by a sheltered angle band are deleted from the spectrum. Typically, sheltering is applied as needed to remove wave energy from any direction which is blocked from a straight-line approach to the site by protruding land forms. Details of the model application for this study are given in Chapter 5.

\section{Wave Ponding on Reefs}

Wave-forced impoundment of water over reefs, often called wave ponding, is caused by overtopping and breaking of waves onto the reef platform. As waves overtop and break on the reef, water is collected over the reef causing an elevated water level across the full width of the reef (Figure 7). Seelig (1983) conducted a set of laboratory flume experiments for fringing reef profiles typical of Guam to investigate hydraulics of reef-lagoon systems. Wave ponding level resulting from wave overtopping and breaking was included in the study. Parameter ranges were varied as follows: still-water depth at the reef crest was specified to be $0 \mathrm{~m}(0 \mathrm{ft})$ and $2 \mathrm{~m}(6.6 \mathrm{ft})$, wave periods ranged from 8 to $16 \mathrm{sec}$, and irregular deepwater significant wave height ranged from 2.5 to $10.7 \mathrm{~m}(8.2$ to $35.1 \mathrm{ft})$.

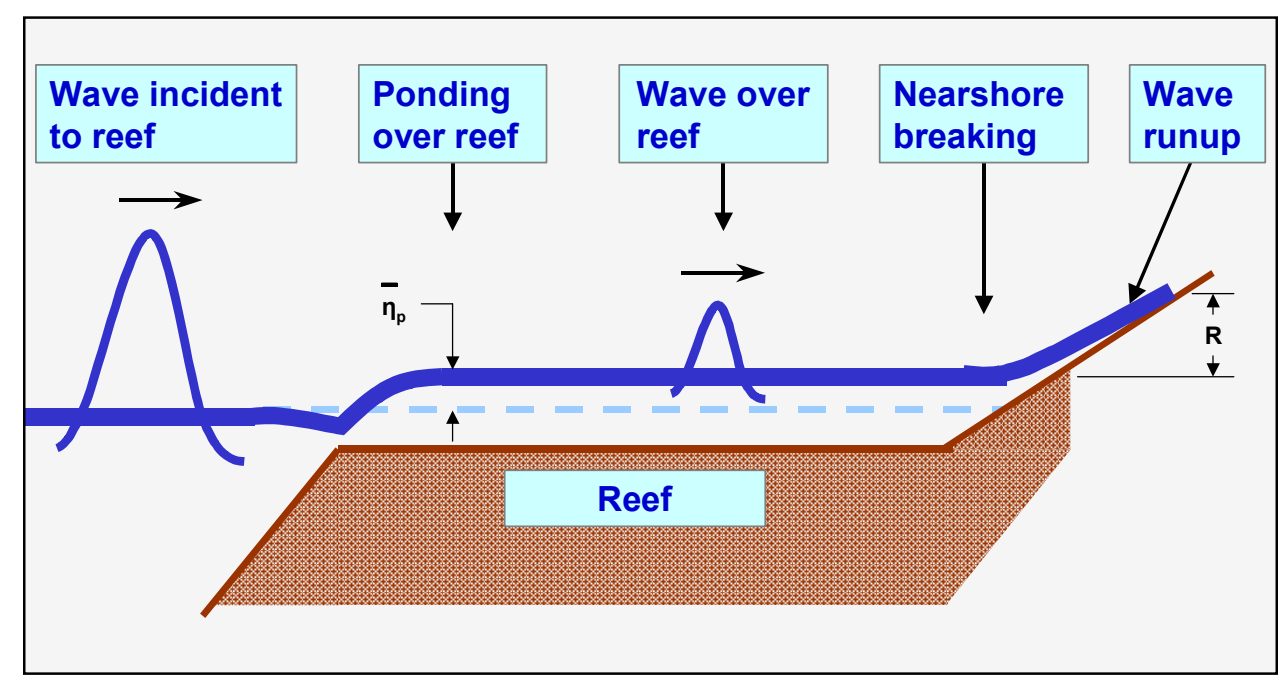

Figure 7. Definition sketch of wave ponding and runup

Seelig found that ponding water level is a function of still-water level (astronomical tide and storm surge), deepwater significant wave height, and wave period. Gourlay (1996) confirmed these findings. Ponding level varies with time, increasing when a group of several unusually high waves impacts the reef and decreasing during sequences of lower waves. Mean ponding level can be estimated by (Seelig 1983)

$$
\bar{\eta}_{p}=a_{1}+a_{2} \log \left(H_{0}^{2} T_{p}\right)
$$


where

$$
\begin{aligned}
& \bar{\eta}_{p}=\text { mean ponding level } \\
& H_{0}=\text { deepwater significant wave height incident to the reef face } \\
& T_{p}=\text { peak wave period }
\end{aligned}
$$

$a_{1}$ and $a_{2}=$ empirical coefficients dependent on the still-water level

Table 6 gives values of the empirical coefficients for irregular waves when $H_{0}$ and $\bar{\eta}_{p}$ are expressed in meters.

\begin{tabular}{|l|l|l||}
\hline \hline \multicolumn{2}{||l||}{$\begin{array}{l}\text { Table } \mathbf{6} \\
\text { Ponding Level Coefficients for Irregular Waves (Seelig 1983) }\end{array}$} \\
\hline Depth, $\mathbf{m}$ (ft) & $\mathrm{a}_{1}$ & $\mathrm{a}_{\mathbf{2}}$ \\
\hline \hline $0(0)$ & -0.92 & 0.77 \\
\hline $2(6.6)$ & -1.25 & 0.73 \\
\hline \hline
\end{tabular}

\section{Wave Setup and Runup}

Ponding is considered as an increase in water level over the full width of the reef, extending from the seaward edge of the reef flat to shore. An additional, localized, increase in water level at the shore is caused by final breaking of waves re-formed within the lagoon system after initial breaking on the reef. The localized increase at shore includes wave setup due to wave breaking on the nearshore slope and wave runup on land (Figure 7). Wave setup is affected by local bathymetry; runup is highly influenced by local bathymetry and topography. As with ponding, these processes are modeled along a onedimensional profile representative of the nearshore bathymetry and topography at each study site.

Wave setup results when the pressure gradient of the sloping water surface (i.e., mean still-water depth) is in equilibrium with the cross-shore directed radiation stress, which represents the gradient of momentum of incoming waves in the shoreward direction:

$$
\frac{d \bar{\eta}}{d x}=-\frac{1}{\rho g d} \frac{d S_{x x}}{d x}
$$

where

$$
\begin{aligned}
\bar{\eta}= & \text { mean still-water level, } \rho \text { is the water density, } g \text { is the acceleration } \\
& \text { due to gravity } \\
S_{x x}= & \text { cross-shore component of the cross-shore directed radiation stress }
\end{aligned}
$$


$d=$ depth

$x=$ cross-shore distance

Under the assumption of linear wave theory, wave setup in the surf zone is

$$
\frac{d \bar{\eta}}{d x}=-\frac{3}{16} \frac{1}{d+\bar{\eta}} \frac{d\left(H^{2}\right)}{d x}
$$

where $H$ is the wave height. A representative wave setup for irregular waves can be approximated with guidance from the Coastal Engineering Manual

(Headquarters, U.S. Army Corps of Engineers, 2002), which is based on Equation 8 adapted to irregular waves.

Wave runup, $R$, is the maximum water-surface elevation caused by the uprush of water at shore from a breaking wave. The Shore Protection Manual (1984) provides guidance for estimating runup due to a wide range of incident wave conditions and smooth, uniform bottom slopes, based on extensive laboratory testing with regular waves. Wave setup effects are included in the runup estimates. A method for adapting the guidance to nonuniform slopes is also provided, based on the composite slope approach of Saville (1958).

Guidance is included for runup reduction factors to account for effects of slope roughness and porosity.

Incident wave height for setup and runup calculations is determined from wave conditions incident to the seaward edge of the reef, water depth over the reef, and reef width. For a very wide reef, incident wave height for setup and runup calculations is assumed to be equal to the maximum breaking wave height that can be sustained over the reef estimated by

$$
H_{b}=\gamma_{b} d_{b}
$$

where

$$
\begin{aligned}
& H_{b}=\text { height of the breaking wave } \\
& d_{b}=\text { water depth over the reef } \\
& \gamma_{b}=\text { breaking depth index }
\end{aligned}
$$

The breaking depth index can range from 1.1 to 0.4 across reefs, with the smaller values tending to be reached across wide reefs (Gerritsen 1980; Hardy et al. 1990). A typical breaking depth index for regular waves on beaches has a value of 0.78 , but this value is overly conservative for calculation of design significant wave heights landward of the reef edge (Smith 1993).

For high offshore wave conditions and narrow reefs, incident wave height for setup and runup calculations can be expected to be higher than the limit given by Equation 9. Reef width is included in the modeling approach for this study based 
on results from Hardy et al. (1990) and Smith (1993) and calibration efforts of Militello, Scheffner, and Thompson (2003). The wave approaching the seaward reef face is assumed to decay in height with propagation distance over the reef.

The stable decayed wave height reached over a wide reef is given by Equation 9 with tide, storm surge, and ponding included in $d_{b}$. When wave height incident to the reef exceeds the stable decayed wave height, the decay with propagation distance over the reef is given by

$$
\frac{d\left(H^{2}\right)}{d x}=\frac{-\kappa}{d_{b}}\left(H^{2}-\gamma_{b}{ }^{2} d_{b}^{2}\right)
$$

where $\kappa$ is a decay constant.

\section{Empirical Simulation Technique}

Coastal inundation studies, storm damage reduction programs, and design of coastal structures typically require an extreme water level analysis to obtain peak water-surface elevations for planning and design. Because typhoons and hurricanes occur infrequently at a given site, abundant historical water level stages are generally not available and standard ranking methods cannot be effectively applied in stage-frequency analysis. Thus, numerical models are often invoked for simulating a larger population of storm-surge events. Traditionally, modeled tropical storms have been synthesized via a joint probability method (JPM) to describe storm attributes, such as maximum wind speeds and pressure deficits. A set of hypothetical storms is built from a combination of parameter values obtained by statistical analysis of historical storms.

The JPM requires that all parameters are statistically independent. However, storm parameters are not statistically independent, and the assumption of independence leads to errors when the JPM approach is taken. Because storm parameters are related, random grouping of parameters can cause simulation of storms that may not occur in nature. For example, one parameter may be assigned a value typical of a weak storm, whereas a second parameter may be assigned a value representative of an intense storm. Thus, an artificial level of uncertainty is introduced into the stage-frequency computations. For this study and other recent CHL studies, an alternative approach, the EST, has been taken. The EST preserves the interdependence of typhoon parameters, which is an advantage over the JPM. Details of the EST are given in Borgman et al. (1992); Scheffner and Borgman (1993), and Scheffner et al. (1999).

\section{Description of technique}

EST is a statistical resampling technique that uses historical data to develop joint probability relationships among the various measured storm parameters. In contrast to the JPM, there are no simplifying assumptions concerning development of the probability density functions describing historical events. Thus, the interdependence of parameters is maintained. In this manner, parameter probabilities are site-specific, do not depend on fixed parametric relationships, 
and do not assume parameter independence. Thus the EST is distribution-free and nonparametric.

For this study, the EST was developed to generate numerous multi-year intervals of possible future typhoon events for the study site. The ensemble of modeled or simulated events is consistent with statistics and correlations of past storm activity at the site. Furthermore, the EST permits random deviations in storm behavior (when compared to historic events) that could occur in the future. For example, simulated typhoons are permitted to make landfall at locations other than those made by historical storms. These random deviations can also result in more intense storms than the historical events themselves, allowing for the possibility of a future typhoon being the storm of record.

The simulation approach requires specifying a set of parameters that describes the dynamics of some physical system, such as typhoons. These parameters, which must be descriptive of both the physical process being modeled and the effects of that process, are defined as an N-dimensional vector space. The parameters that describe the physical attributes of the process are referred to as input vectors. For example,

$$
\underline{v}=\left(v_{1}, v_{2}, v_{3}, \ldots, v_{N}\right)
$$

In the case of typhoons, pertinent input vectors include: the central pressure deficit, the radius to maximum winds, minimum distance from the eye of the storm to the location of interest, forward speed of the eye, and the tidal phase during the event. These values can be defined for each specific location and correspond to each particular historical or hypothetical event of the total set of storm events used in the study.

The second class of vectors involve some selected response resulting from the $N$-dimensional parameterized storm, i.e.,

$$
\underline{r}=\left(r_{1}, r_{2}, r_{3}, \ldots, r_{M}\right)
$$

For typhoons, response vectors can include maximum water level, shoreline erosion, dune recession, wind-generated wave height and period, bottom erosion, overtopping rate, or any response that can be attributed to the passage of the storm. The maximum total water-surface elevation is often the response vector of greatest interest.

Although response vectors are related to input vectors

$$
v \Rightarrow r
$$

the interrelationship is highly nonlinear and involves correlation relationships that cannot be directly defined, i.e., a nonparametric relationship. For example, in addition to the storm-input parameters, storm surge is a function of local bottom topography, shoreline slope and exposure, ocean currents, etc., as well as their spatial and temporal gradients. It is assumed that these combined properties are implicit in the response vector. Atmospheric, hydrodynamic, and other 
models are applied as needed to compute water level response vectors as a function of the input vectors and local bottom topography together with shoreline configuration. Other response vectors such as sediment transport, shoreline response, and dune recession require application of additional models.

A representative subset of storms is selected from the full set of historical storms. This subset is referred to as the training set. Those storms comprising the training set are subsequently used as input to numerical models for computing the desired response vectors. The training set usually includes historical events but may include historical storms with a deviation or perturbation, such as a typhoon with a slightly altered path. Some historical events may also be deleted from the training set if two events are nearly identical such that both would produce the same response.

The training set of storms can be augmented with additional storms contained in the historical data set. Storm events augmenting the training set are referred to as the statistical set of storms. Whereas numerical models are used for calculating response vectors for those events in the training set, response vectors for the statistical set of storms are interpolated using the training set response vectors. Thus, stage-frequency relationships can be generated using the entire historical data set without need of simulating all storms in that data set.

With the augmented storm data set (i.e., training and statistical storm sets), the EST produces $\mathrm{N}$ simulations of a T-year sequence of events (typhoons), each with their associated input vectors and response vectors. Because there are Nrepetitions of a T-year sequence of events, a variational analysis of the results can be performed with respect to median, worst, least, standard deviation, etc. The following describes the procedures by which the input and response information is used to produce multiple simulations of multiple years of events.

\section{Empirical simulation}

Two criteria are required of the T-year sequence of events. The first criterion is that individual events must be similar in behavior to historical events in order that the interrelationships among the input and response vectors remain realistic. For example, a typhoon with high central pressure deficit and low maximum winds is not a reasonable event - the two parameters are not independent although their exact dependency is unknown.

Simulation of realistic events is accounted for in the nearest-neighbor interpolation resampling technique developed by Borgman et al. (1992). A storm event is identified by random sampling from the total storm population. The procedure is equivalent to drawing and replacing random samples from the full storm event population.

Because simulated events correspond to a specific location, the second criterion to be satisfied is that the total number of storm events selected in the T-years must be statistically representative of the number of historical events that have occurred at the area of study. For this study, 28 typhoon events were 
identified that passed within $370 \mathrm{~km}$ (200 miles) of Rota and Guam during the 53-year period extending from 1945 through 1997.

Output from the EST program is $N$ repetitions of T-years of simulated storm event responses. It is from these responses that frequency-of-occurrence relationships are computed. The computational procedure followed is based on the generation of a probability distribution function corresponding to each of the T-year sequences of simulated data. Additional detail about the EST is given by Scheffner et al. (1999). 


\section{Implementation of Storm Surge Model}

The process required for application of a long-wave hydrodynamic numerical model at a particular site includes grid generation, model calibration, model validation, and production runs. Accuracy of model results is greatly influenced by the accuracy of boundary and forcing conditions, representation of bathymetry over the model domain, and to a lesser degree, the values of certain calibration parameters. Model calibration involves adjustment of the calibration parameters to maximize agreement between model results and measurements.

The water level gauge nearest to Rota is located in Apra Harbor, Guam. Data from this gauge were used for storm surge model calibration and validation in a recent study by Thompson and Scheffner (2002). That calibration and validation is applicable to the present study, as well. The present study grid has the same offshore boundary, tidal forcing, open ocean grid resolution and bathymetry, and islands as the Apra Harbor grid. The principal differences are that the present grid has increased resolution around Rota and coarse resolution around Guam. Tide and storm surge modeling at a small island such as Rota with open coasts and deep surrounding waters is not much changed from open ocean conditions and is not sensitive to details of island bathymetry. Thus, the present grid can be confidently applied to Rota.

Model astronomical tide results for the month of January 1997 illustrate tidal behavior at Rota (Figure 8). Mean tide range is only $15 \mathrm{~cm}(0.5 \mathrm{ft})$. The tide is characterized by a relatively large diurnal inequality. High tides are generally slightly greater than msl and lower low tides typically drop well below msl. This tidal behavior is similar to that for Apra Harbor, though the tide range at Apra Harbor is larger. The model indicates that tides on the east side of the village, in the Sasanhaya embayment, are nearly identical to those on the west side. 


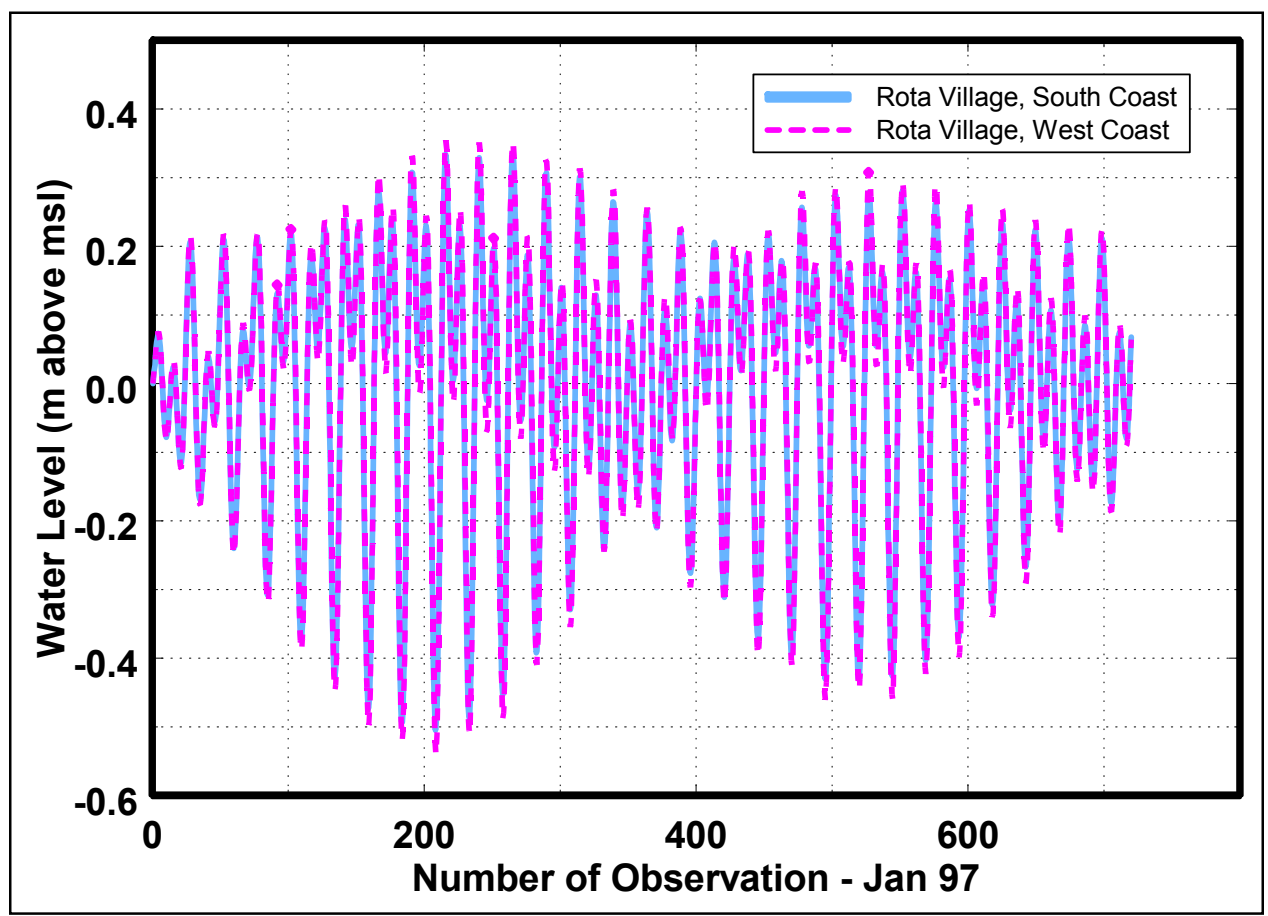

Figure 8. Model astronomical tide, Rota, January 1997 


\section{Development of Stage- Frequency Relationships}

Stage-frequency relationships were developed for the island of Rota in four tasks. First, the training set of storms was developed from a storm database for the western Pacific Ocean, and the PBL model was applied to calculate wind fields associated with each storm in the training set. Second, the storm-surge model was applied with wind and atmospheric pressure forcing from the PBL model as time-dependent input. Time-series of storm-surge elevations associated with each storm were calculated for specified stations. Third, time series of wave parameters were calculated by application of the wave and wave-transformation models. Time series of ponding level, setup, and runup were calculated for each profile location in the study site. Fourth, the EST was applied to compute stagefrequency relationships based on the typhoon event parameters and calculated storm water level elevations.

This chapter briefly reviews procedures implemented for developing stagefrequency relationships for the study area and presents study results. Previous chapters give more detailed background on some aspects of the study. The set of historical storms included in the training set is given in and discussed in Chapter 2 (Table 1). Storm tracks are provided in Appendix A. Detailed discussion of the modeling approach is given in Chapter 3.

\section{Storm Surge/Tidal Elevation Relationship}

Storm-surge elevations are dependent on water depth as well as intensity and angle of approach of the storm. The most accurate method for calculation of surge is inclusion of tides in the storm-surge simulation. However, this approach is not practical for stage-frequency analysis because numerous tidal phases would have to be modeled for each storm in the training set to acquire a representative set of surge and tide combinations. An alternative approach was taken in this study, as in previous studies, to estimate the combined water-surface elevation of the surge and tide. Simulations were performed for each of the 32 storms in the training set, where the still-water level was taken to be msl. Tides were not included in the computations. Because storm surges are small for the study site, the water-surface elevation for the combined surge and tide can be approximated as a linear superposition of the two. Thus, still-water level for stage-frequency computations was calculated by addition of the surge to a specific tidal elevation. 
A total of 45 numerical gauge stations was specified as locations for surge output from the storm-surge model. The key nearshore stations are shown in Figure 9. Stations not shown were secondary sites located seaward of the reef to assess reef effects on storm surge (which were minimal). Appendix B gives the latitude and longitude of all stations. Water-level values were stored at 15-min intervals at each station.

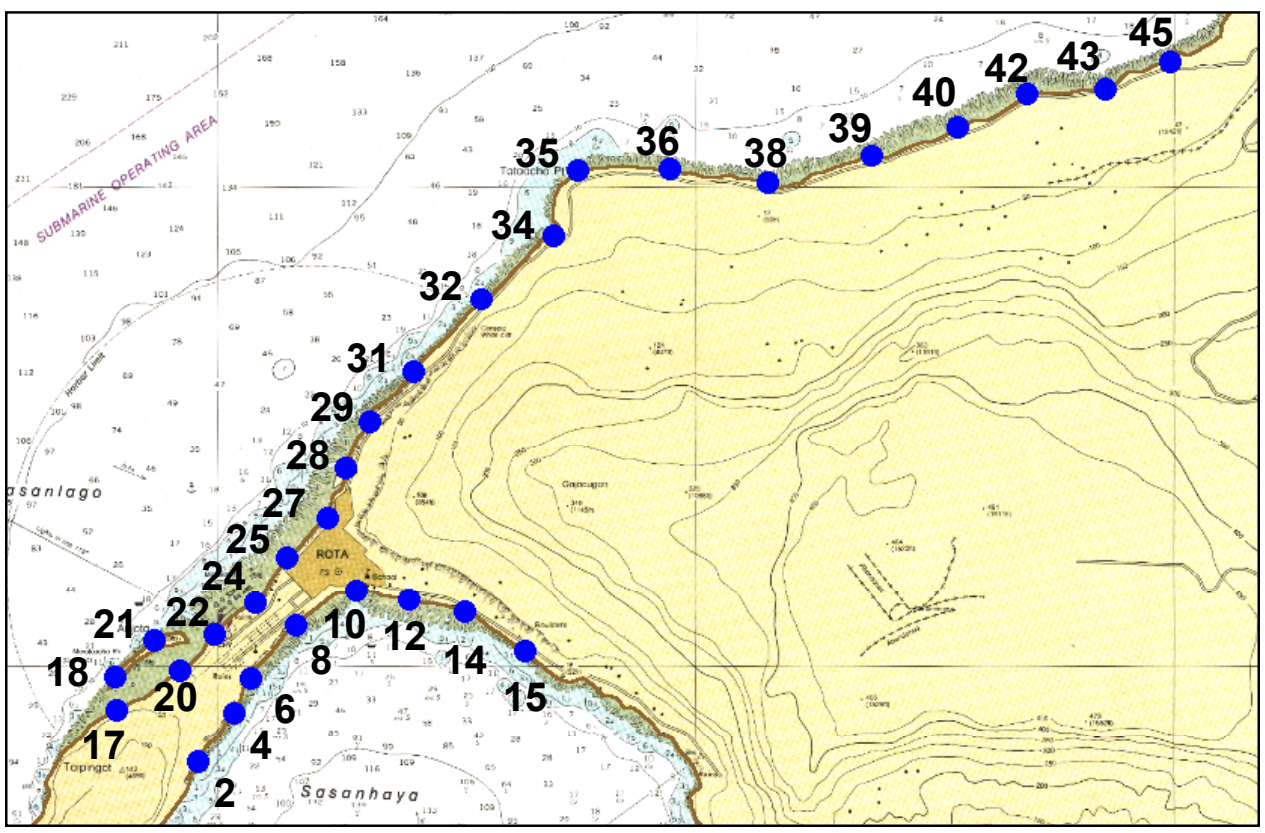

Figure 9. Key nearshore storm surge station locations for Rota

\section{Spectral Wave Transformation}

Waves in the open ocean calculated by the WISWAVE model were transformed to near-breaking by application of WAVTRAN, described in Chapter 3. Waves in the offshore and transformed time series were at 1-hr intervals throughout each storm. Estimates were made of the general nearshore depth contour and shoreline orientation closest to each of the numerical gauge locations specified in Appendix B. In addition, estimates of sheltering angle bands were made based on shoreline geometry. For numerical gauge locations 2-16, located in the Sasanhaya embayment, substantial one- or two-sided sheltering was applied. For numerical gauge locations 17-45, along the exposed northwest- and north-facing coasts, little or no sheltering was applied.

Initially, waves were transformed to a water depth of $10 \mathrm{~m}(33 \mathrm{ft})$. If maximum significant wave height during the typhoon exceeded $4 \mathrm{~m} \mathrm{(13 \textrm {ft } )}(0.4$ times the water depth), WAVTRAN was rerun to transform to a deeper nearshore depth. Nearshore depth was increased in 5-m (16-ft) increments until maximum significant wave height during the storm was less than 0.4 times the depth or until the nearshore depth reached $30 \mathrm{~m}(98 \mathrm{ft})$. This transformation approach is expected to produce realistic incident significant wave heights for calculation of nearshore processes. 


\section{Wave Level Over Reef}

Time series of storm surge and near-breaking waves seaward of the reef were combined to calculate processes over the reef and at shore. Wave ponding over nearshore fringing reefs was calculated at 15-min intervals throughout each storm, as discussed in Chapter 3.

Based on calibration tests and the objective of estimating a maximum inundation level, discussed in the following section, average height of the 1 percent highest waves, $H_{l}$, was used in place of significant height, $H_{s}$, for prebreaking waves incident to the reef face. Thus, ponding, setup, and runup calculations are all based on $H_{l}$ as the incident wave height. The widelyaccepted Rayleigh distribution for wave heights in a sea state gives $H_{1}=1.67$ *

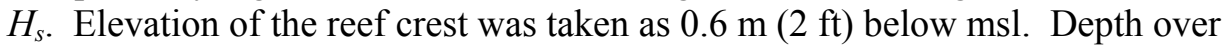
the reef crest was calculated based on a water level that includes astronomical tide and storm surge, and the guidance of Seelig (1983) was applied. When depth over the reef was less than $2 \mathrm{~m}(6.6 \mathrm{ft})$, which was typically the case, ponding was calculated for both cases in Table 6 and an interpolated ponding value was used.

Astronomical tide was included as a single level (msl) in this study for three reasons. First, the tide range is relatively small. Second, tide levels at this location are characteristically in a very narrow range between msl and mhw most of the time, as discussed in Chapter 4. Finally, tidal variations for this application can be effectively introduced in EST modeling, as discussed later.

\section{Wave Setup and Runup}

To calculate wave ponding, setup, and runup and estimate coastal inundation levels, a series of transects was established along the inhabited coasts of Rota. A total of 87 transects fell within the study area. Transect profiles and topographic elevation contours were provided by the Honolulu District. The topographic contours were compiled by photogrammetric methods from aerial photography taken in February 1999 and June 1996. Elevations were specified relative to msl. In addition to the measured profile data, reef width normal to the beach was estimated from the topographic maps. Profiles were extended seaward by the estimated reef width. Each profile is paired with a nearby storm surge station (or two stations bracketing the profile if storm surge is better interpolated between adjacent stations). Transect profile numbers and corresponding storm surge station numbers from Appendix B are given in Appendix C.

This approach for estimating coastal inundation levels has been used in previous studies at other locations. Although the approach is useful for practical studies, it has some significant limitations. Nearshore wave processes, particularly wave runup at the shore, can be strongly affected by the threedimensionality of land forms. The modeling approach does not capture this nearshore three-dimensionality. Extreme coastal inundation events along Rota coasts are primarily due to huge waves attacking the shore. Storm surge is only a small component of extreme events. In contrast, storm surge is the major 
component of coastal inundation along U.S. Atlantic and Gulf of Mexico coasts. Thus, in an exposed island environment such as Rota, accuracy of coastal inundation calculations is much more dependent on accurate modeling of waves, which naturally vary greatly over short distances, much more so than storm surge. More comprehensive modeling tools are under development but were not available at the time of this study.

The traditional modeling approach, described in Chapter 3, is aimed at estimating a significant inundation level at shore. The actual water level at shore varies constantly as waves run up and down the shore face, ponding level over the reef pulses up and down, and incident wave characteristics fluctuate. The significant inundation level at shore is representative of the higher water levels produced by these time-varying processes over a time period when the underlying sea state and storm conditions are relatively stationary, typically 1 hour.

An objective of this study, as in a companion study of American Samoa (Millitello, Scheffner, and Thompson 2003), is to estimate maximum inundation level at shore. This level is higher than the significant inundation level. Maximum inundation level was estimated by adapting the nearshore modeling approach in Chapter 3 to produce more extreme water levels and calibrating/ verifying with observed maximum inundation levels. The primary observations were collected by FEMA after Hurricane Ofa impacted American Samoa in February 1990. Details are given by Militello, Scheffner, and Thompson (2003).

Changes to the Chapter 3 approach to produce estimates of extreme water level, resulting from the American Samoa calibrations, include increasing significant wave height incident to the reef to represent $H_{l}$ and using a value of $\gamma_{b}=0.78$ in Equation 9. Although the American Samoa calibrations resulted in $\kappa=0.02$ in Equation 10, subsequent calibration at Inarajan, Guam, suggested $\kappa=0.03$. Since Guam and Rota are near neighbors, the Guam calibration was used for $\kappa$ in this study. During an intense nearby typhoon, water depth over the reef (including tide, storm surge, and ponding) can exceed $2.4 \mathrm{~m}(8 \mathrm{ft})$, giving nearshore wave heights shoreward of a wide reef of over $1.9 \mathrm{~m}(6 \mathrm{ft})$. Nearshore wave height can be considerably higher when the fringing reef is narrow.

Profiles 18-20 required an additional consideration. These profiles are partially sheltered by Anjota Island, which parallels the shore and reaches elevations of 3.7-5.2 $\mathrm{m}(12-17 \mathrm{ft}) \mathrm{msl}$ over much of its length. The island is connected to Rota by a shore-perpendicular roadway with crown elevation of $3.4 \mathrm{~m} \mathrm{(11 \textrm {ft } )}$ msl. Since Anjota Island lies within the fringing reef, approximately $150 \mathrm{~m}$ $(500 \mathrm{ft})$ from shore and $90 \mathrm{~m}(300 \mathrm{ft})$ from the seaward edge of the reef, waves were assumed to be completely refracted and traveling straight toward shore when they reached the island. Guidance for diffraction of directionally-spread, spectral waves around a semi-infinite breakwater was applied to estimate the effect of sheltering by Anjota Island (Headquarters, U.S. Army Corps of Engineers, 2002). Diffraction coefficients were determined based on a local water level of $+2.4 \mathrm{~m}(+7.8 \mathrm{ft}) \mathrm{msl}$ and 16 -sec peak wave period, representative of the most severe storms modeled. The coefficients can be expected to be conservative for less severe storms, which typically have lower water levels over the reef and shorter wave periods. Estimated diffraction coefficients (significant 
wave height at sheltered location divided by significant wave height incident to Anjota Island) for Profiles 18-20 are 0.8, 0.4, and 0.71, respectively.

Wave setup and runup time series were estimated at the 87 coastal profiles for the 32 storms using the approach described in Chapter 3 and in the previous paragraphs. Runup level, calculated with the composite slope method, was multiplied by a runup reduction factor of 0.9 to account for effects of slope roughness and porosity. The runup reduction factor value was chosen based on guidance in the Shore Protection Manual and past experience. Runup level includes wave setup. Separate estimates of wave setup, apart from runup, are needed because maximum still-water levels are also a study objective; and wave setup is considered to be a constant increase in local water level (for given tide, surge, and incident wave conditions).

The highest runup levels computed for five profiles in the Sasanhaya embayment exceeded the maximum profile elevation. These profiles, facing southeast along the narrowest part of the Taipingot peninsula, received special consideration because they can be overtopped during severe storms. At the request of the Honolulu District, the portion of these profiles above $+3.66 \mathrm{~m}$ $(+12 \mathrm{ft}) \mathrm{msl}$ was treated as a uniform slope extending to an elevation beyond possible runup levels. The profiles are 5 through 9 and corresponding slopes (provided by Honolulu District) are 200, 800, 400, 267, and 19 percent, respectively. Stage-frequency information on these artificial slopes includes fictitious runups which will be subsequently reduced with a low bluff methodology applied by Honolulu District prior to flood mapping.

\section{Validation of Maximum Water Levels}

The methodology used to estimate maximum water level along Rota coasts has been calibrated to observations at other locations. Until the final phase of this study, no observations were available to validate the methodology on Rota. However, late in the study, the Honolulu District was able to collect observations from a moderate storm. The eye of Typhoon Chataan passed just south of Guam on July 5, 2002, moving toward the northwest. Maximum sustained winds during its approach and passage were 39-41 m/s (75-80 knots). Maximum water level observations were surveyed at 14 points along the Rota coast in the aftermath of Typhoon Chataan. Points are located in the village area at the north end of the Sasanhaya embayment. Study profiles in this area are numbers 10 and 11 . The modeled storm that most resembles Typhoon Chataan is Typhoon Nina (0853). Nina had maximum sustained winds, track direction, and forward speed comparable to Chataan. The biggest difference between the two storms is that Nina's track was displaced further north about $1 \mathrm{deg} 110 \mathrm{~km}$ (70 miles). Since both storms passed well south of Rota and both could generate waves from the strong side of the storm headed into the Sasanhaya embayment, the displacement difference may not be a major impact.

Model maximum water levels from Nina (0853) at profiles 10 and 11 are compared to observations from Chataan nearest the profiles (Table 7). The excellent agreement helps to validate the modeling approach for estimating maximum water levels along the Rota coasts. 


\begin{tabular}{|l|l|l||}
\hline \multicolumn{2}{||l||}{$\begin{array}{l}\text { Table } 7 \\
\text { Comparison of Observed and Modeled Maximum Water Level }\end{array}$} \\
\hline \hline Profile Number & Observation (Chataan), $\mathbf{m}$ (ft) & Model (Nina), $\mathbf{m}$ (ft) \\
\hline \hline 10 & $+4.8(+15.8)$ & $+4.9(+16.1)$ \\
\hline 11 & $+6.8(+22.3)$ & $+6.5(+21.2)$ \\
\hline \hline
\end{tabular}

\section{Stage-Frequency Relationships}

Stage-frequency relationships were calculated for 87 profiles along the study area by application of the EST. These relationships were computed for maximum water level at intervals of $2,5,10,25,50,75,100$, and 500 years. Water levels at intervals up to 100 years are meaningful relative to the historical storm record length (53 years). However, reliable 500-year water levels would require a much longer historical database.

Input for the EST included maximum water level calculated for each of the 32 storms in the training set. The EST was applied to two maximum water level calculations. In one, maximum water level was the total of storm surge, ponding level, and runup (which includes wave setup). The other calculation was based on maximum still-water level, the total of storm surge, ponding, and wave setup. Both provide useful information about coastal inundation levels: maximum water level is the highest level reached by ocean water, reached briefly by the highest runup; maximum still-water level is the highest sustained water level (an average water level over many runup/rundown cycles). Maximum water level at Profiles 5-9 is a fictitious level which will be subsequently reduced by the Honolulu District prior to flood mapping, as discussed previously. Tables of stage-frequency relationship values for each profile are given in Appendix D. Maximum expected water level values and standard deviations are given in the tables. Plots of 100-year water levels and profile topography are given in Appendix E.

In addition to the stage-frequency relationships, values of wave parameters and water level components for each storm at selected profiles are presented in Appendix F. The values correspond to the time during the storm passage at which total water level, including runup, reached its maximum at the profile. These tables provide a perspective on the stage-frequency relationships in Appendix D. For example, the strong impact of one hypothetical variation of Olive (5163) on profiles in the Sasanhaya embayment (profiles 1-14) is evident. 


\section{Summary and Conclusions}

A set of typhoon-induced stage-frequency relationships was developed for inhabited coasts of the island of Rota, Commonwealth of the Northern Mariana Islands. The objective was to assist the Honolulu District in estimating extreme maximum inundation levels and maximum still-water levels with return period of up to 500 years. Calculation of surge, wind and pressure field, and wave characteristics were performed for 28 historical storms and four hypothetical variations of historical storms through application of numerical models. Waveinduced ponding, setup, and runup were calculated at 87 profile locations specified by the Honolulu District.

The PBL model was applied for simulation of storms whose path brought the storm center within a 370-km (200-mile) radius of Rota and Guam. Historical data from the storms were input into the PBL model for calculation of wind and pressure fields. Atmospheric fields calculated by the PBL model were applied as forcing for the long-wave hydrodynamics and wave models.

The long-wave hydrodynamic model ADCIRC was applied for calculation of storm surge in the study area. Model calculations in a previous study on a similar grid with the same exterior boundary and tidal forcing but detailed resolution around Apra Harbor, Guam, the nearest tide gauge location, compared well to National Ocean Service (NOS) tide and storm surge data. For storm surge calculation, ADCIRC used wind and pressure fields calculated by the PBL model as the atmospheric forcing.

Deepwater wave heights, periods, and directions for each storm were calculated by application of the wave model WISWAVE. These deepwater waves were transformed to the seaward slope of the fringing coastal reef by application of the wave-transformation model WAVTRAN.

Storm surge (wind- and atmospheric pressure-induced) was simulated for 32 historical and hypothetical storms and referenced to mean sea level. Because the island of Rota is a volcanic cone with steep sides, shallow shelf areas do not exist around the island. In contrast to the Atlantic Ocean and Gulf of Mexico coasts of the United States, the storm surge does not build appreciably near shore. Consequently, storm surge (without consideration of waves) is generally small and contributes only a small amount to coastal inundation during severe storms. Wave effects, including ponding on the reefs, setup, and runup, are the major causes of high inundation levels during storm events. 
The EST was applied to calculate stage-frequency relationships based on historical storm parameters and calculated response to the storms. These relationships were calculated from the maximum total water levels computed for each storm (including storm surge, ponding, and runup) and from the maximum still-water levels for each storm (including storm surge, ponding, and wave setup). Stage-frequency values and their standard deviations were calculated for $2,5,10,25,50,75,100$, and 500-year return periods at the 87 profiles. Water levels at intervals up to 100 years are meaningful relative to the historical storm record length (53 years). However, reliable 500-year water levels would require a much longer historical database. The methodology was calibrated to observations so that stage-frequency values for maximum total water level are expected to represent maximum debris line inundation levels.

The present methodology, in which wave setup and runup at shore are calculated along shore-perpendicular profiles without consideration of actual variations in bathymetry and topography on either side of the profiles, is limited in its ability to accurately model coastal inundation levels on the island of Rota. However, the methodology provides useful information about coastal inundation levels. When modeling tools better suited to nearshore processes along island coasts with fringing reefs become available, the possibility of updating this study should be considered. 


\section{References}

Atkinson, G. D., and Holliday, C. R. (1977). "Tropical cyclone minimum sea level pressure/maximum sustained wind relationship for the western North Pacific," Monthly Weather Review 105, 421-427.

Borgman, L., Miller, M., Butler, L., and Reinhard, R. (1992). "Empirical simulation of future hurricane storm histories as a tool in engineering and economic analysis." Fifth International Conference on Civil Engineering in the Oceans. American Society of Civil Engineers, College Station, TX, 2-5 November 1992.

Bouws, E., Gunther, H., Rosenthal, W., and Vincent, C. L. (1985). "Similarity of the wind wave spectrum in finite depth water 1 spectral form," Journal of Geophysical Research 1(C1), 975-986.

Cardone, V. J., Greenwood, C. V., and Greenwood, J. A. (1992). "Unified program for the specification of hurricane boundary layer winds over surfaces of specified roughness," Contract Report CERC-92-1, U.S. Army Engineer Waterways Experiment Station, Vicksburg, MS.

Flather, R. A. (1988). "A numerical model investigation of tides and diurnalperiod continental shelf waves along Vancouver Island," Journal of Physical Oceanography 18, 115-139.

Gerritsen, F. (1980). "Wave attenuation and wave set-up on a coastal reef," Proceedings of the Seventeenth Coastal Engineering Conference. ASCE, 444-461.

Gourlay, M. R. (1996). "Wave set-up on coral reefs. 2. Set-up on reefs with various profiles," Coastal Engineering 28, 17-55.

Gravens, M. B., Kraus, N. C., and Hanson, H. (1991). “GENESIS: Generalized model for simulating shoreline change. Report 2, workbook and system user's manual," Technical Report CERC-89-18, U.S. Army Engineer Waterways Experiment Station, Vicksburg, MS.

Hardy, T. A., Young, I. R., Nelson, R. C., and Gourley, M. R. (1990). "Wave attenuation of an offshore coral reef," Proceedings of the Twenty-Second Coastal Engineering Conference, ASCE, 330-334. 
Headquarters, U.S. Army Corps of Engineers. (2002). Coastal Engineering Manual, EM 1110-2-1100, Washington, DC.

Hubertz, J. M. (1992). "User's guide to the Wave Information Studies (WIS) wave model, Version 2.0,” WIS Report 27, U.S. Army Engineer Waterways Experiment Station, Vicksburg, MS.

Jelesnianski, C. P., and Taylor, A. D. (1973). "A preliminary view of storm surges before and after storm modifications," NOAA Technical Memorandum ERL WMPO-3, Weather Modification Program Office, Boulder, CO.

Jensen, R. E. (1983). "Methodology for the calculation of a shallow-water wave climate," WIS Report 8, U.S. Army Engineer Waterways Experiment Station, Vicksburg, MS.

JTWC. (1991). “Tropical cyclones affecting Guam, 1671-1990," NOCC/JTWC Tech Note 91-2, U.S. Naval Oceanography Command Center, Joint Typhoon Warning Center, Guam.

Kolar, R. L., Gray, W. G., Westerink, J. J., and Luettich, R. A. (1993). "Shallow water modeling in spherical coordinates: Equation formulation, numerical implementation, and application," Journal of Hydraulic Research 32(1), 324.

Mark, D. J. (1996). "Southern Guam typhoon stage-frequency analysis," Miscellaneous Paper CERC-96-7, U.S. Army Engineer Waterways Experiment Station, Vicksburg, MS.

Mark, D. J., and Scheffner, N. W. (1997). "Coast of Delaware hurricane stagefrequency analysis," Miscellaneous Paper CHL-97-1, U.S. Army Engineer Waterways Experiment Station, Vicksburg, MS.

Militello, A., Scheffner, N. W., and Thompson, E. F. (2003). "Hurricaneinduced stage-frequency relationships for the territory of American Samoa," Technical Report CHL-98-33 (revised), U.S. Army Engineer Research and Development Center, Vicksburg, MS.

National Imagery and Mapping Agency. (1999). "Digital nautical chart (DNC)," set of CD-ROM disks, U.S. Department of Defense.

Resio, D. T., and Perrie, W. (1989). "Implications of an $\mathrm{f}^{4}$ equilibrium range for wind-generated waves," Journal of Physical Oceanography 19, 193-204.

Saville, T., Jr. (1958). "Wave runup on composite slopes," Proceedings of the Sixth Conference on Coastal Engineering. ASCE, Council on Waves.

Scheffner, N. W., and Borgman, L. E. (1993). "Stochastic time-series representation of wave data," Journal of Waterway, Port, Coastal and Ocean Engineering. ASCE, 118(4), 337-351. 
Scheffner, N. W., Clausner, J. E., Militello, A., Borgman, L. E., Edge, B. L., and Grace, P. J. (1999). "Use and application of the empirical simulation technique: User's guide," Technical Report CHL-99-21, U.S. Army Engineer Waterways Experiment Station, Vicksburg, MS.

Seelig, W. N. (1983). "Laboratory study of reef-lagoon system hydraulics," Journal of Waterway, Port, Coastal and Ocean Engineering 109(4), 380391.

Shore Protection Manual. (1984). $4^{\text {th }}$ ed., 2 Vol, U.S. Army Engineer Waterways Experiment Station, U.S. Government Printing Office, Washington, DC.

Smith, J. M. (1993). "Nearshore wave breaking and decay," Technical Report CERC-93-11, U.S. Army Engineer Waterways Experiment Station, Vicksburg, MS.

Thompson, E. F., and Cardone, V. J. (1996). "Practical modeling of hurricane surface wind fields," Journal of Waterway, Port, Coastal and Ocean Engineering 122(4), 195-205.

Thompson, E. F., and Scheffner, N. W. (2002). "Typhoon-induced stagefrequency and overtopping relationships for the commercial port road, territory of Guam," Technical Report CHL-02-1, U.S. Army Engineer Research and Development Center, Vicksburg, MS.

Westerink, J. J., Luettich, R. A., Baptista, A. M., Scheffner, N. W., and Farrar, P. (1992). "Tide and storm surge predictions using finite element model," Journal of Hydraulic Engineering, ASCE, 118(10), 1373-139. 


\section{Appendix A Typhoon Tracks}

This appendix shows typhoon tracks for each storm contained in the Empirical Simulation Technique (EST) training set. Each figure consists of an upper and lower panel. The upper panel shows storm tracks through the immediate vicinity of the islands of interest for the study. Some figures do not show a storm track in the upper panel because the storm did not pass within the bounds of the graphical limits. The lower panel shows storm tracks for the region covered by the numerical grid developed for the study. The outer boundary of the numerical grid is shown as the large circle. Storm tracks can also be seen outside of the grid region. Dots in the upper and lower panels show the 6-hr best track locations for the storms. Arrows indicate direction of storm travel. 


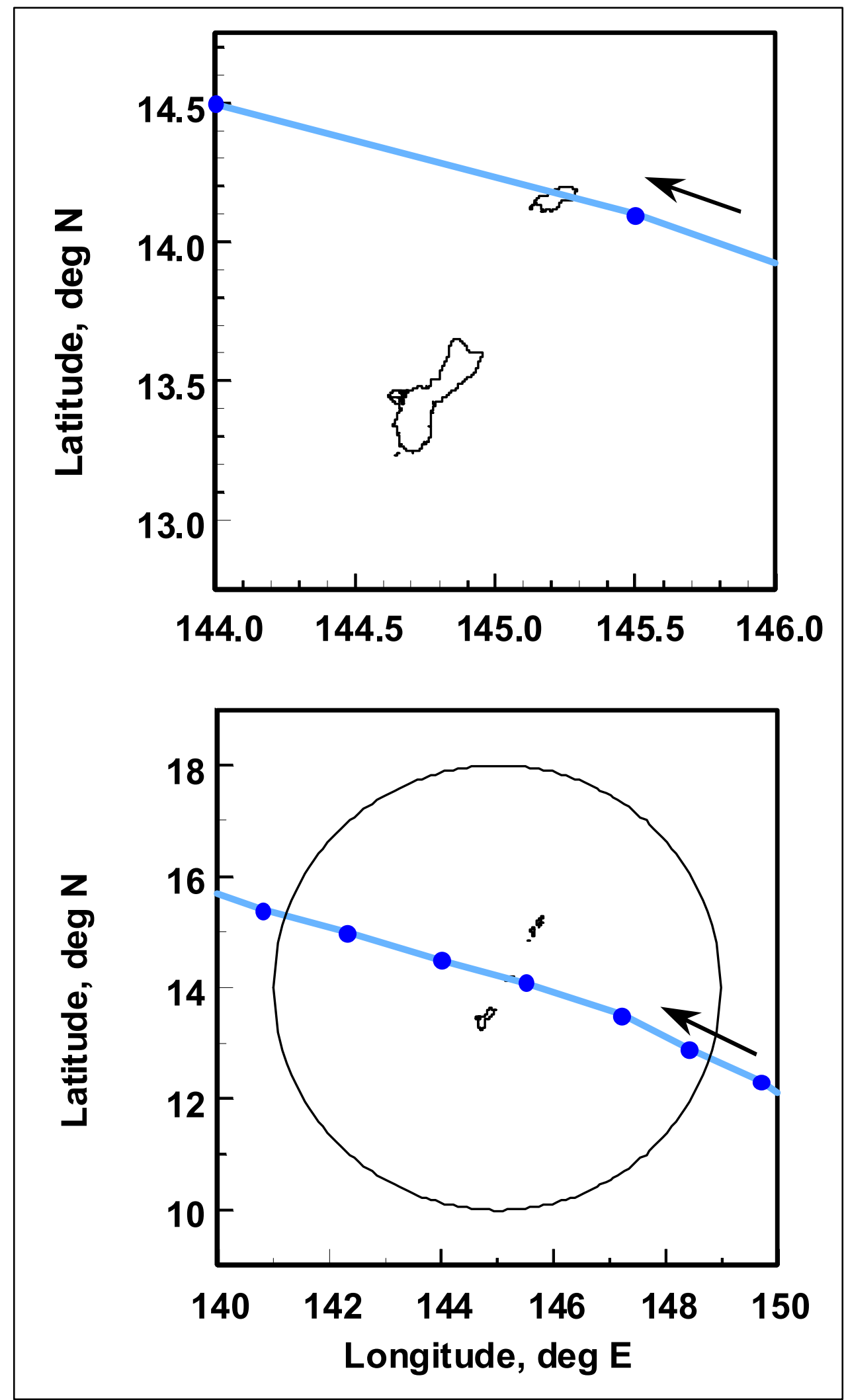

Figure A1. Storm track for Agnes (2348) 


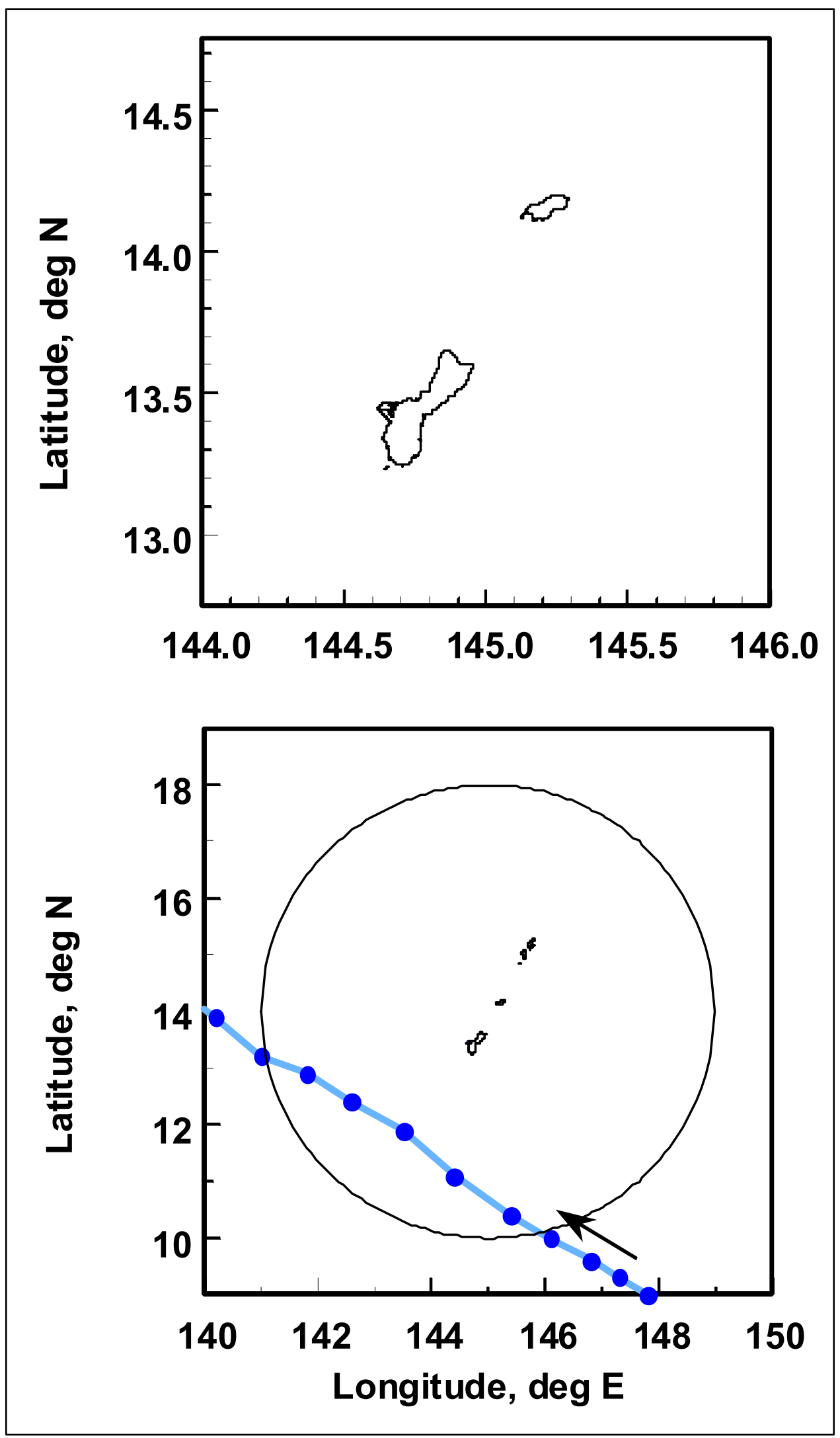

Figure A2. Storm track for Doris (0150) 


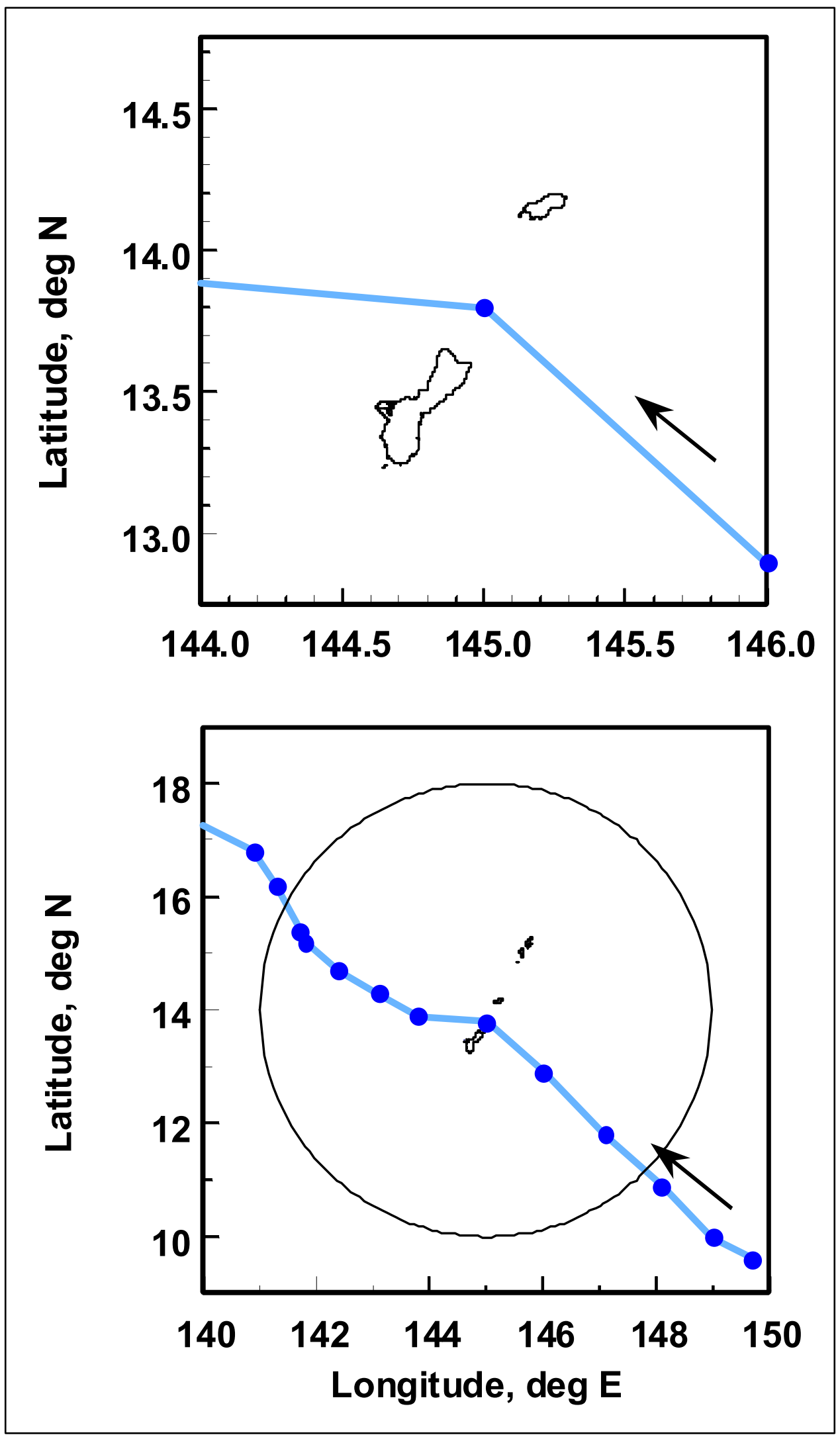

Figure A3. Storm track for Nina (0853) 


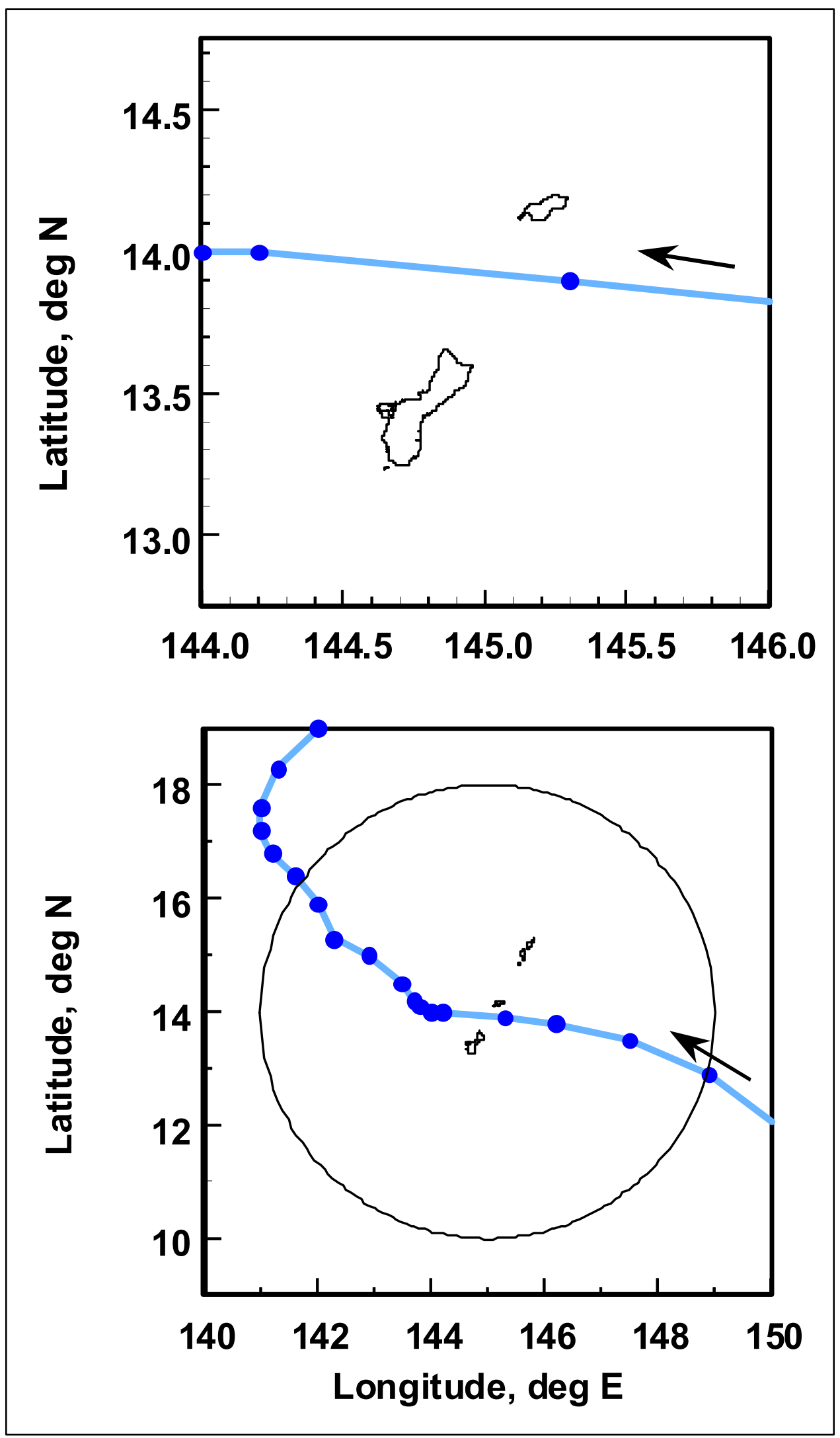

Figure A4. Storm track for Alice (1953) 


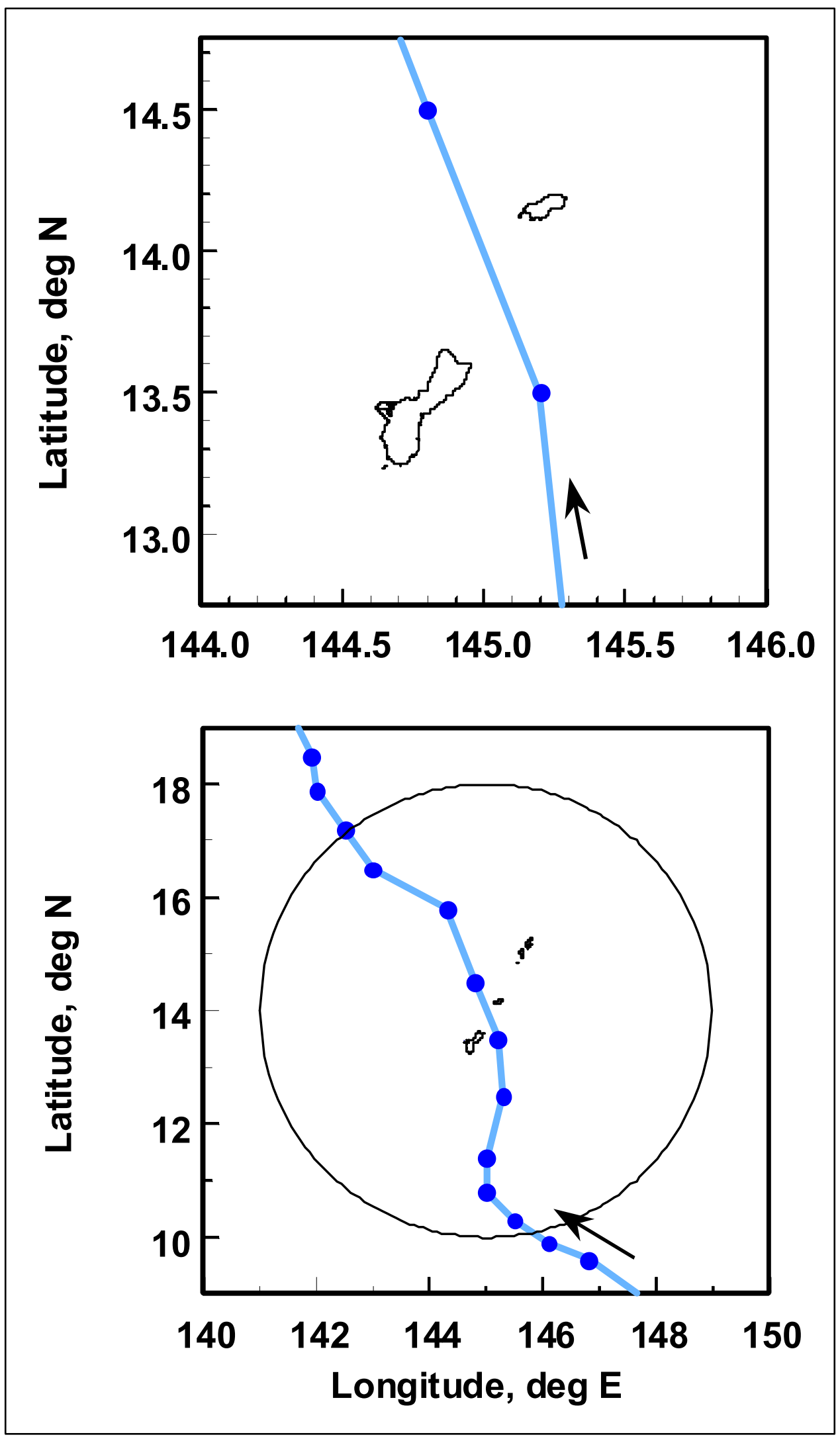

Figure A5. Storm track for Hester (1557) 


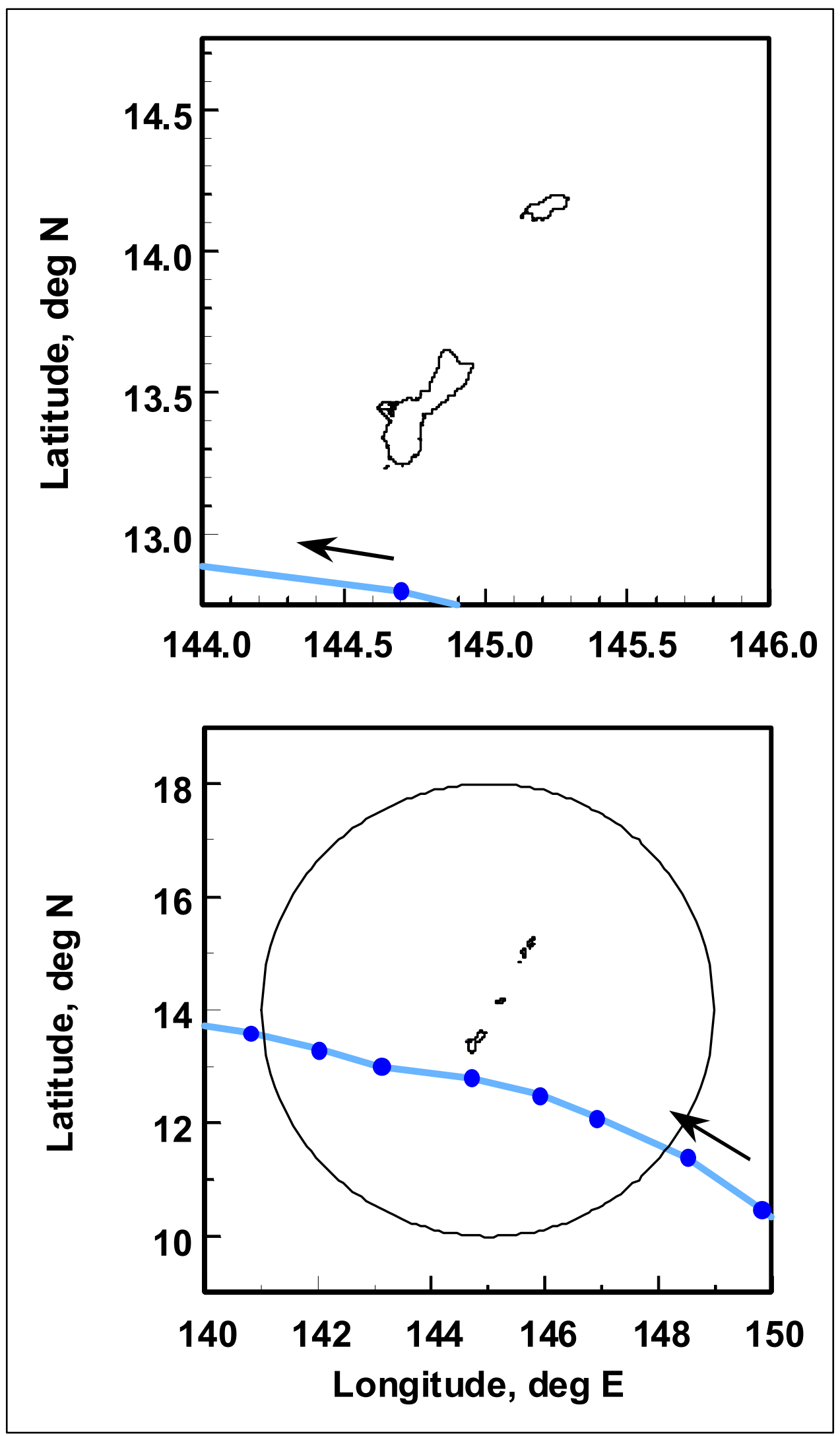

Figure A6. Storm track for Lola (2057) 


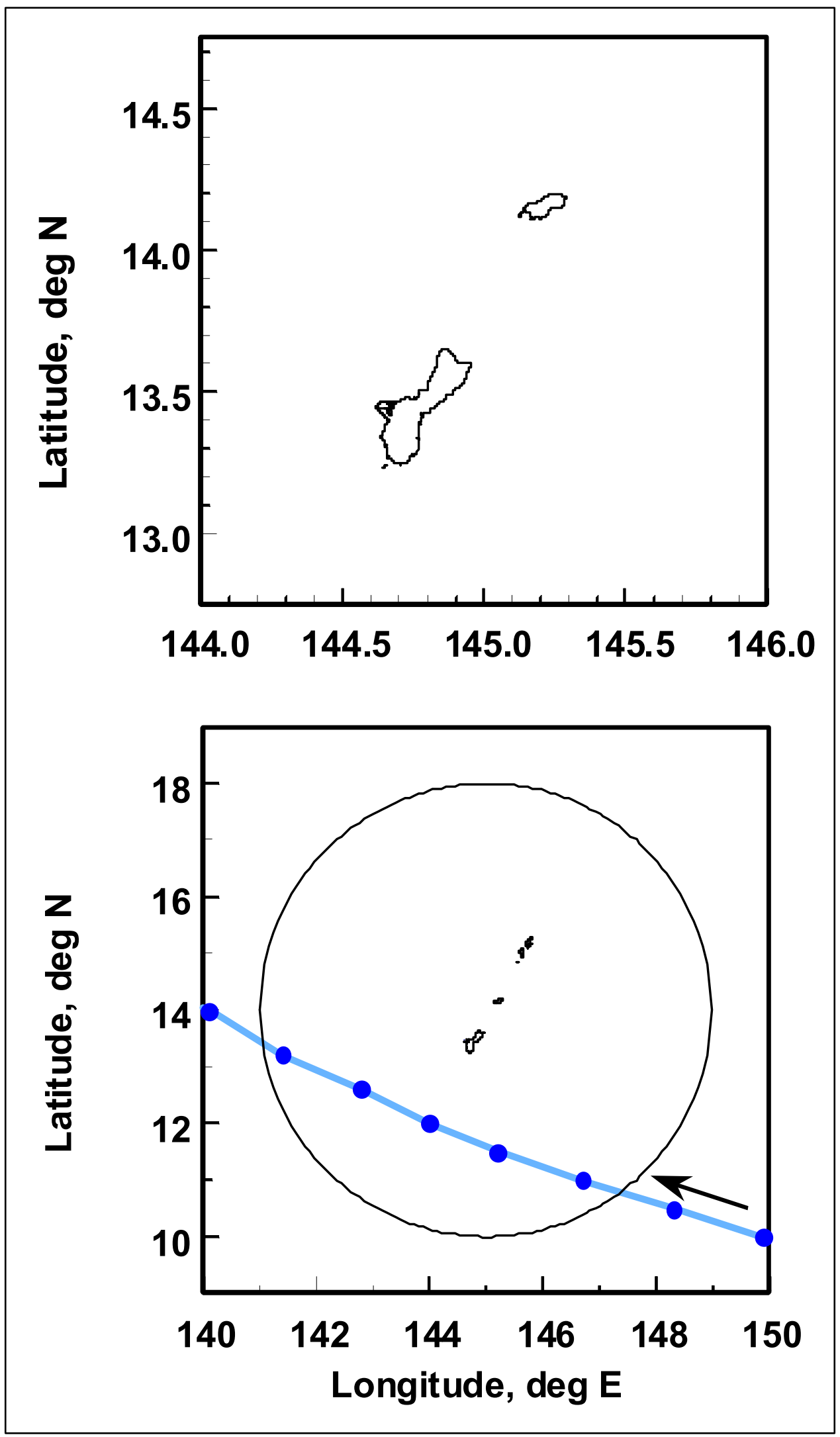

Figure A7. Storm track for Nancy (1861) 


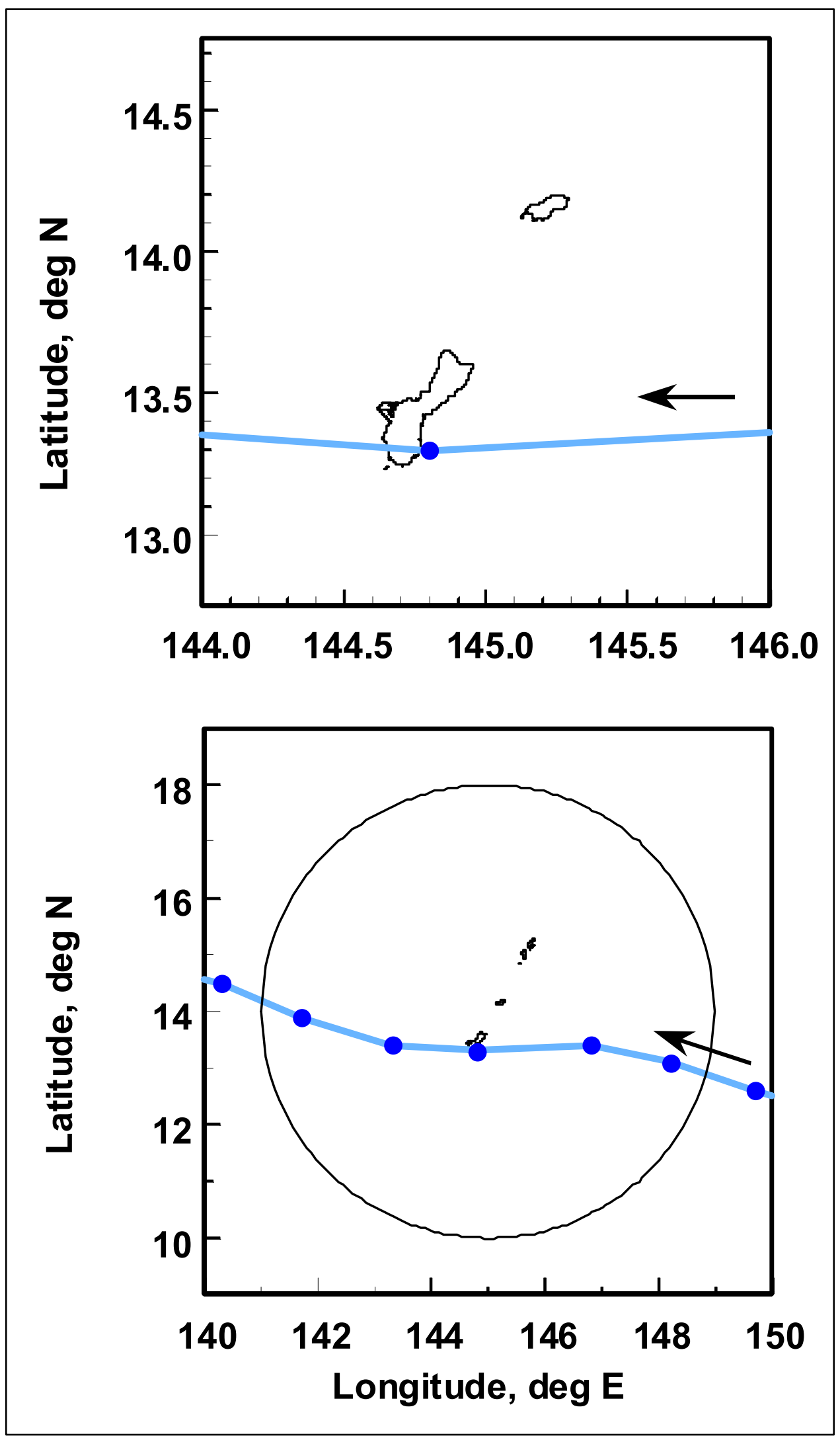

Figure A8. Storm track for Karen (2762) 


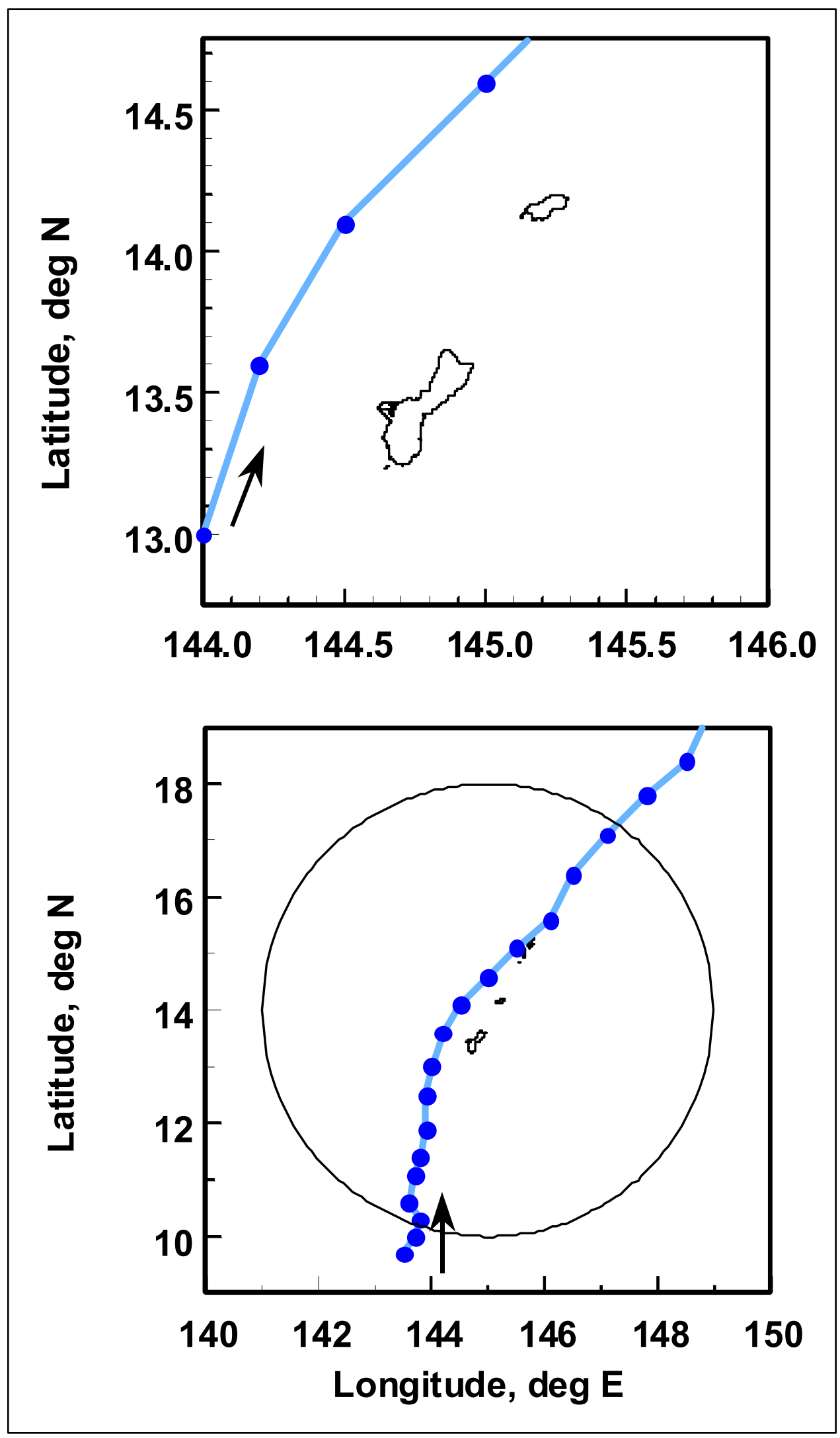

Figure A9. Storm track for Olive (0163) 


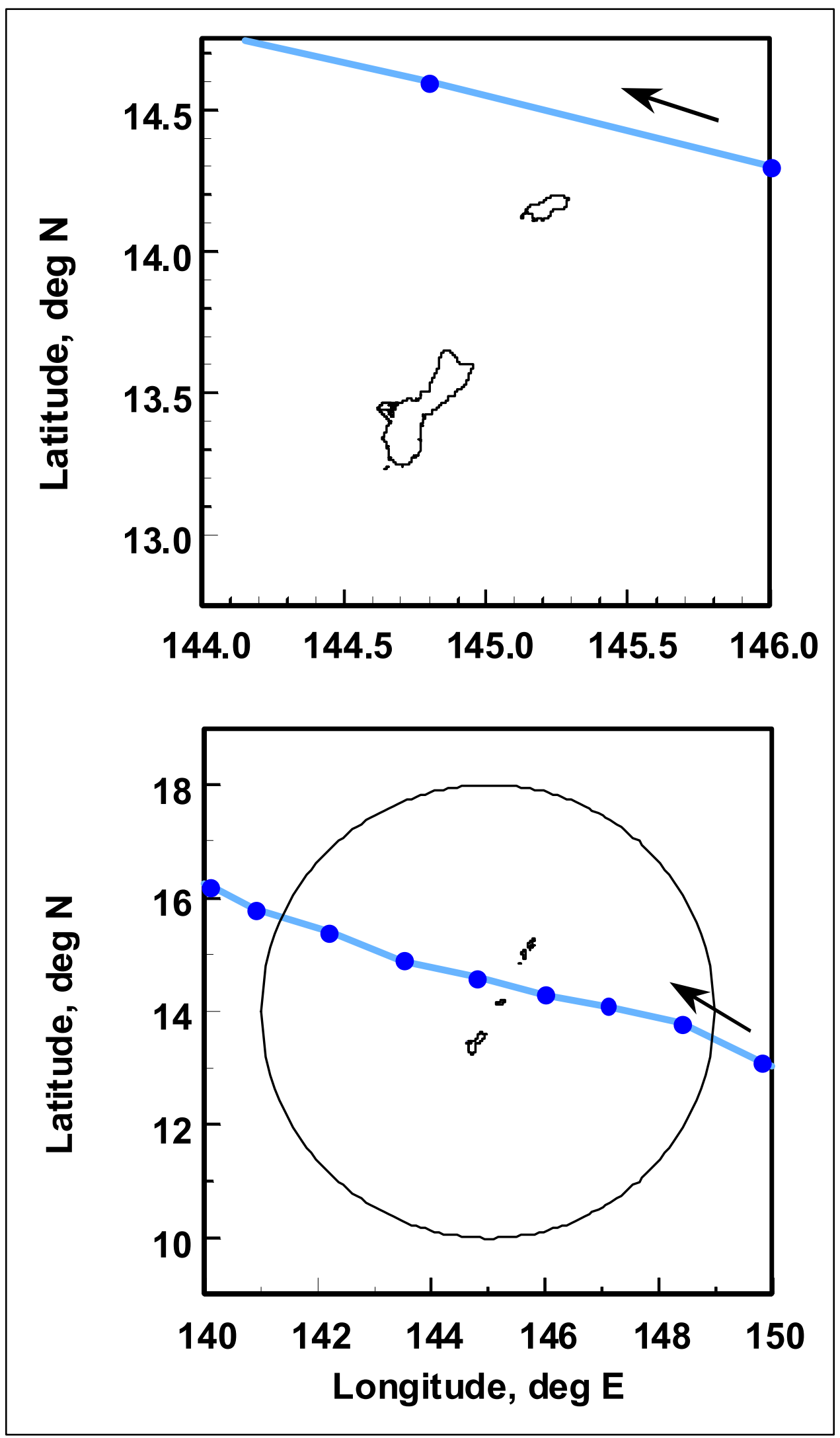

Figure A10. Storm track for Susan (2563) 


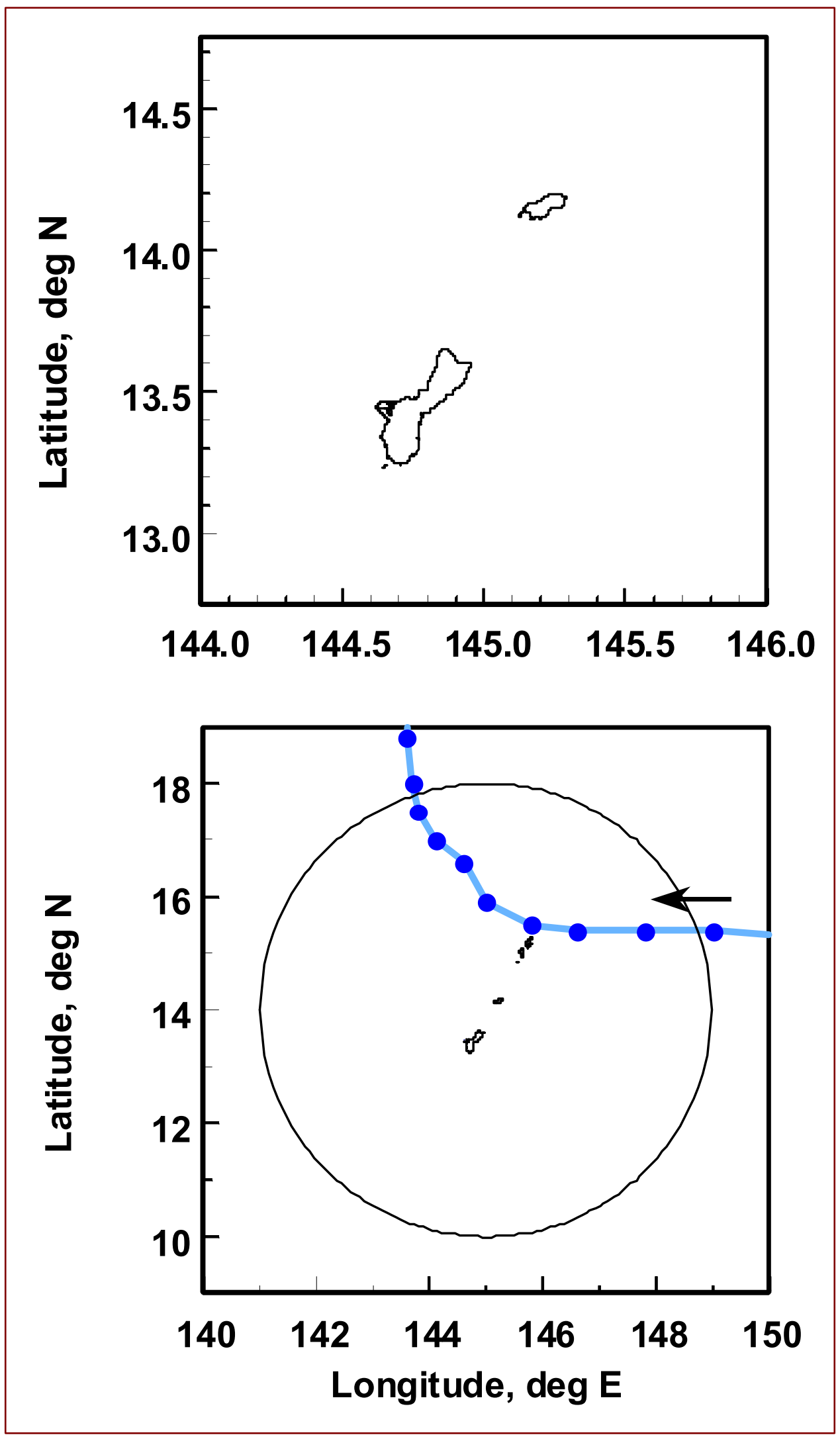

Figure A11. Storm track for Bess (2965) 


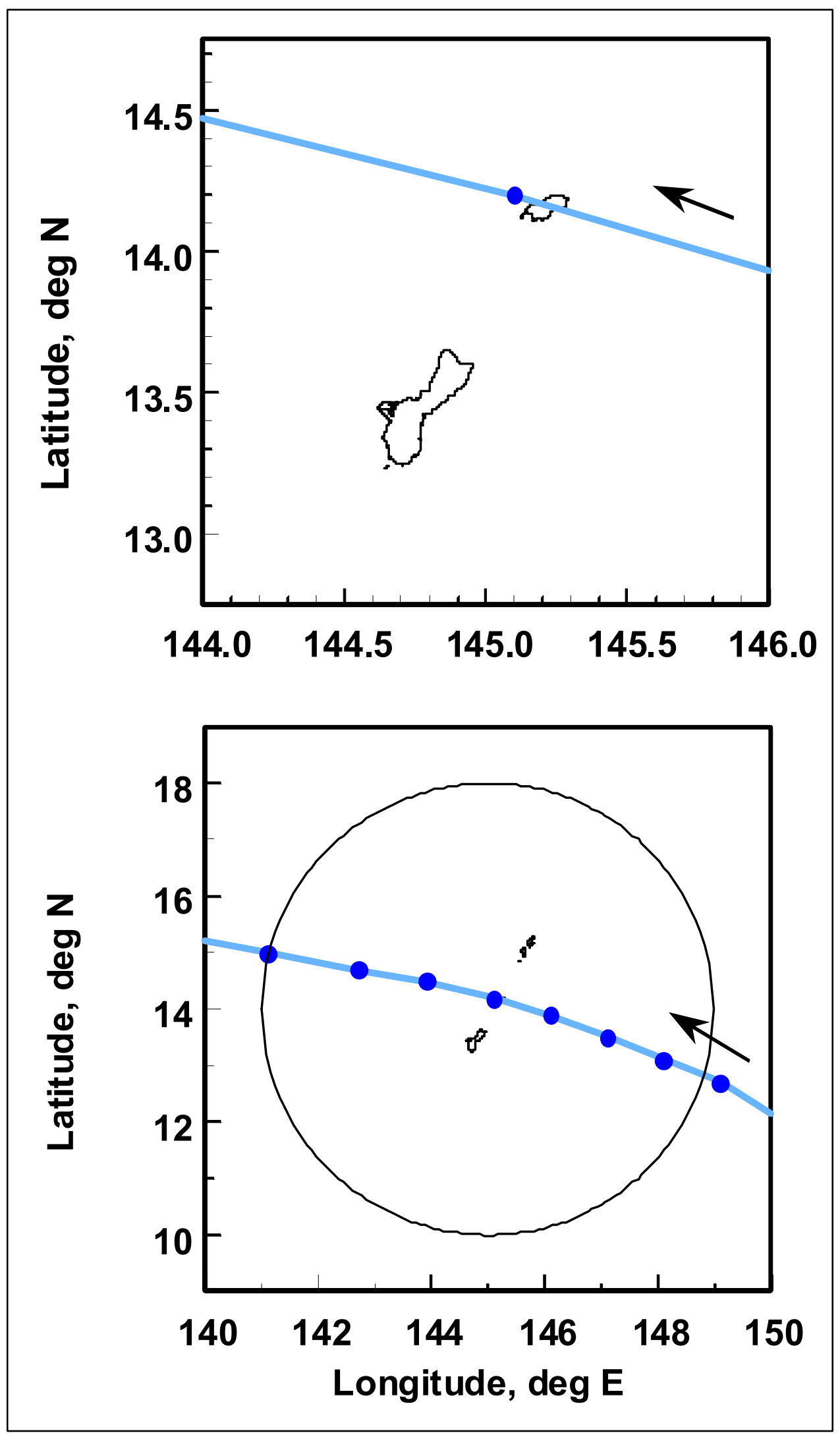

Figure A12. Storm track for Gilda (3367) 


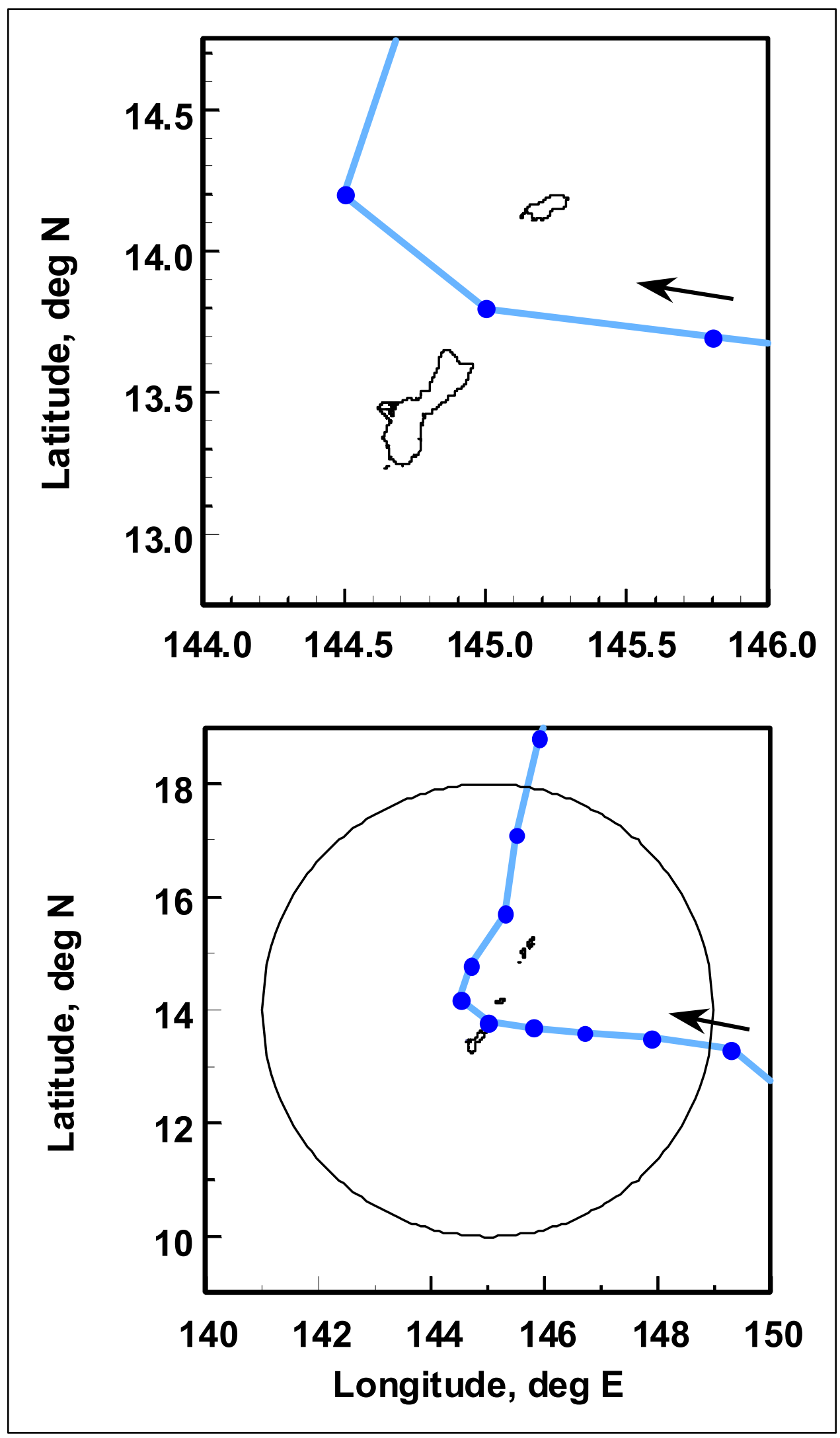

Figure A13. Storm track for Irma (2168) 


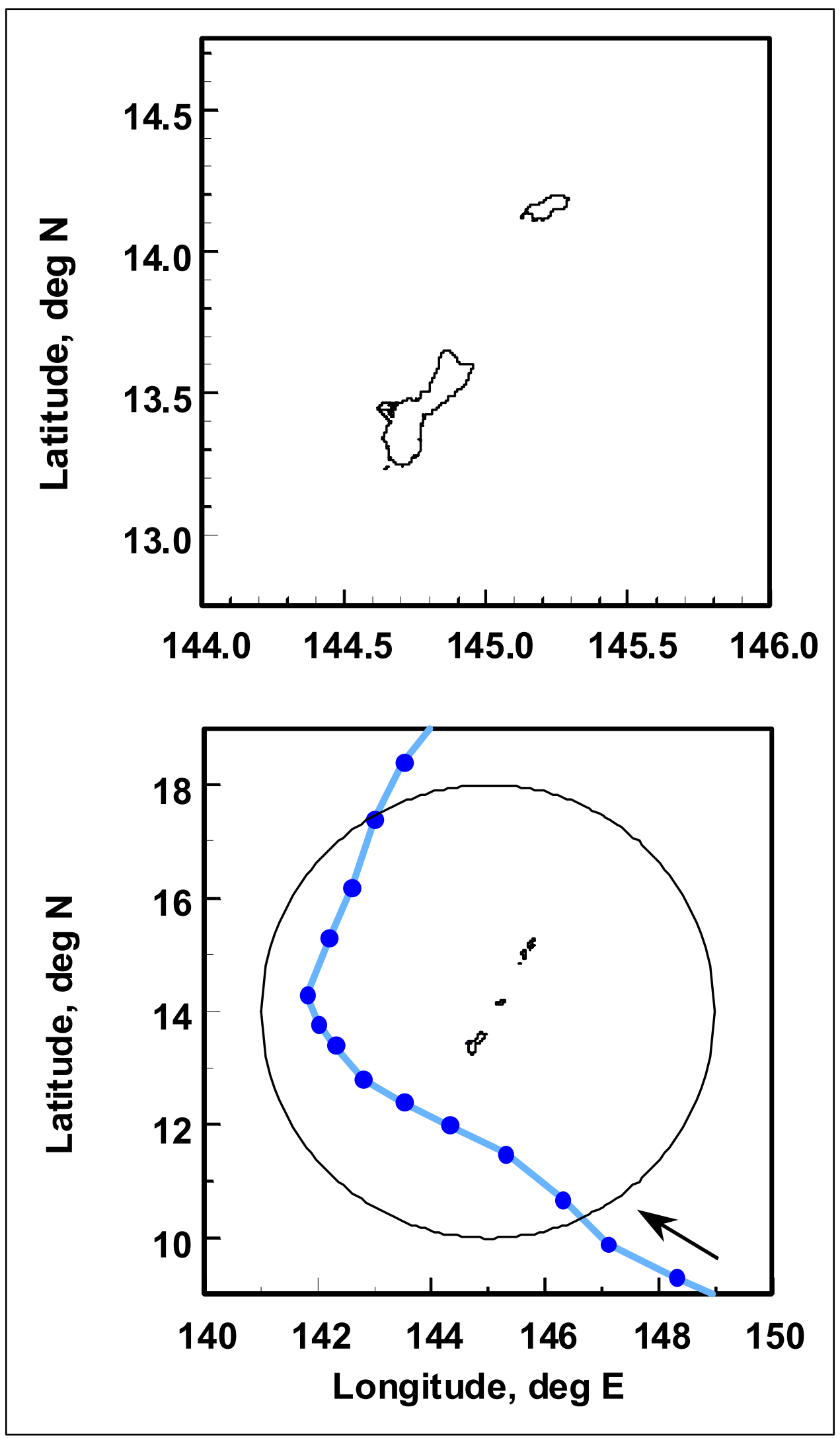

Figure A14. Storm track for Amy (0571) 


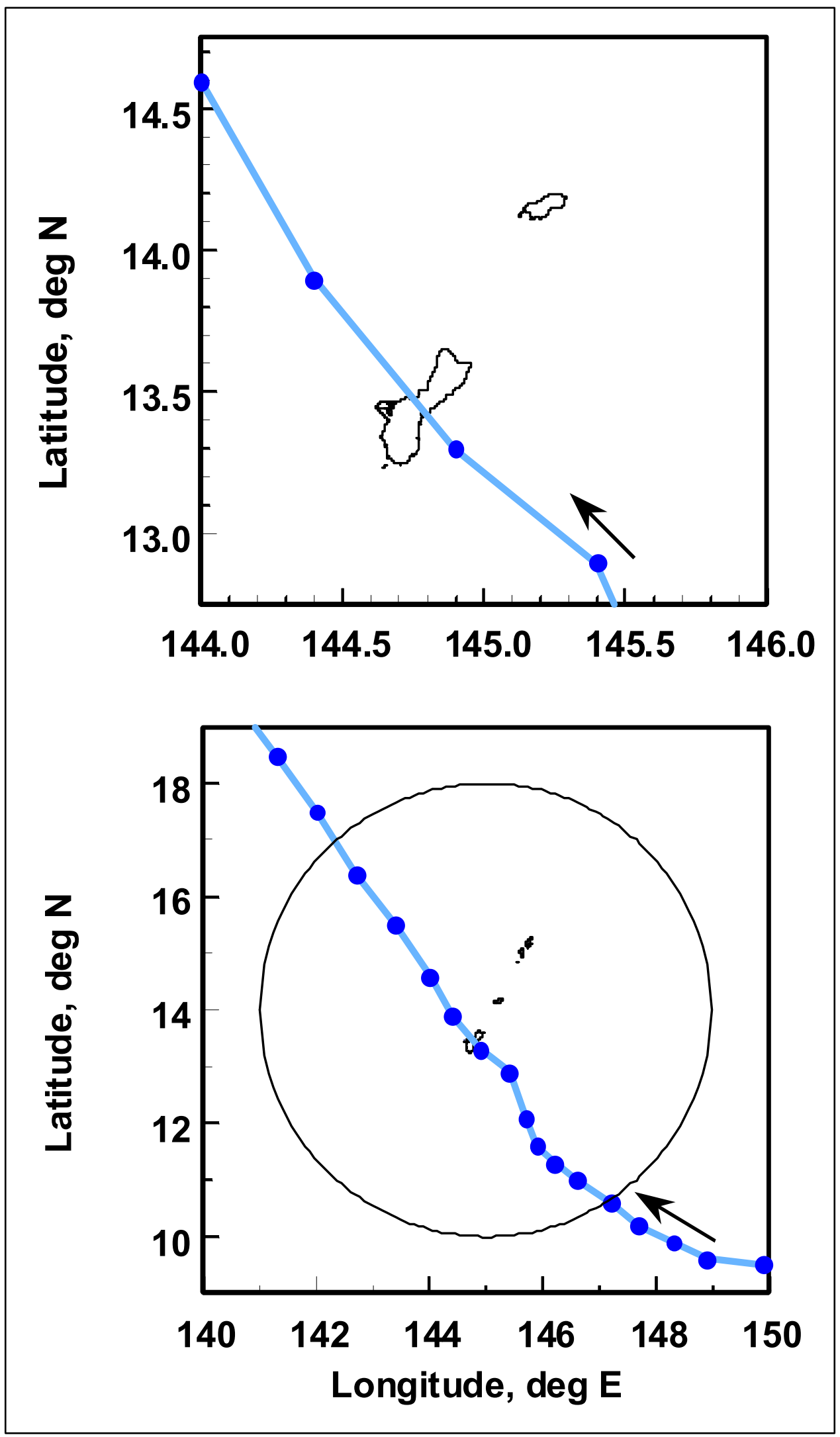

Figure A15. Storm track for Pamela (0676) 


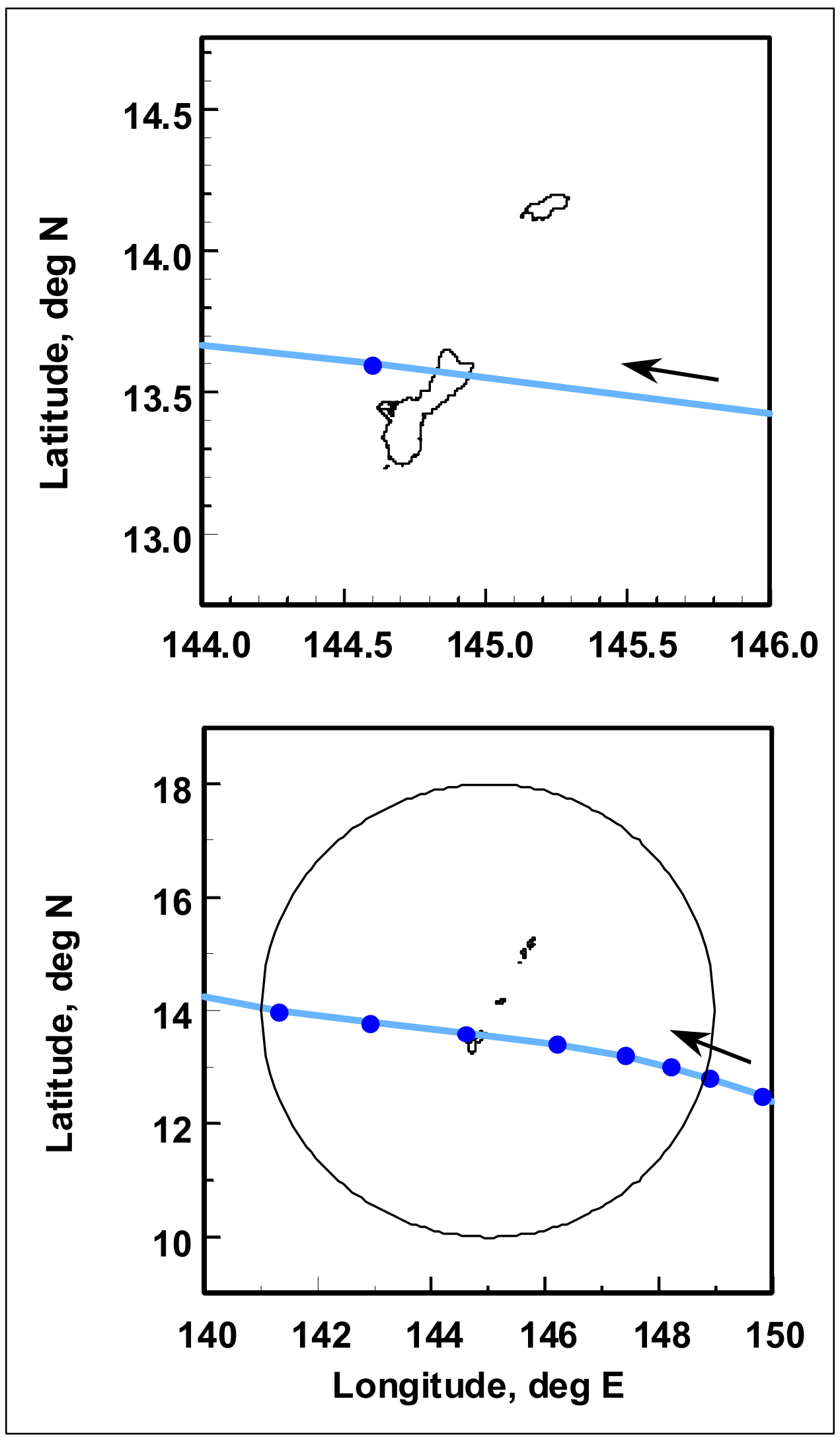

Figure A16. Storm track for Kim (1977) 


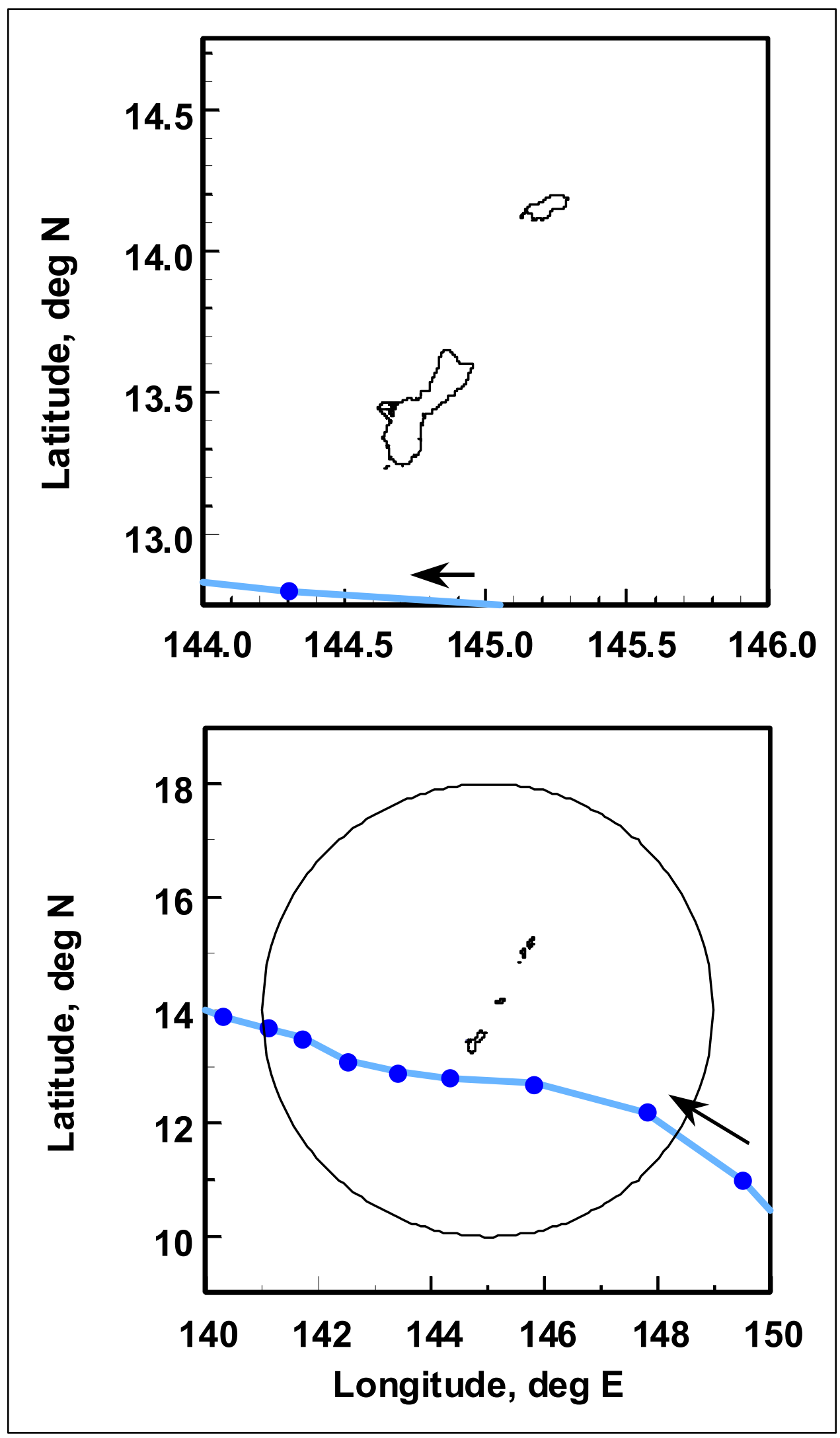

Figure A17. Storm track for Tip (2379) 


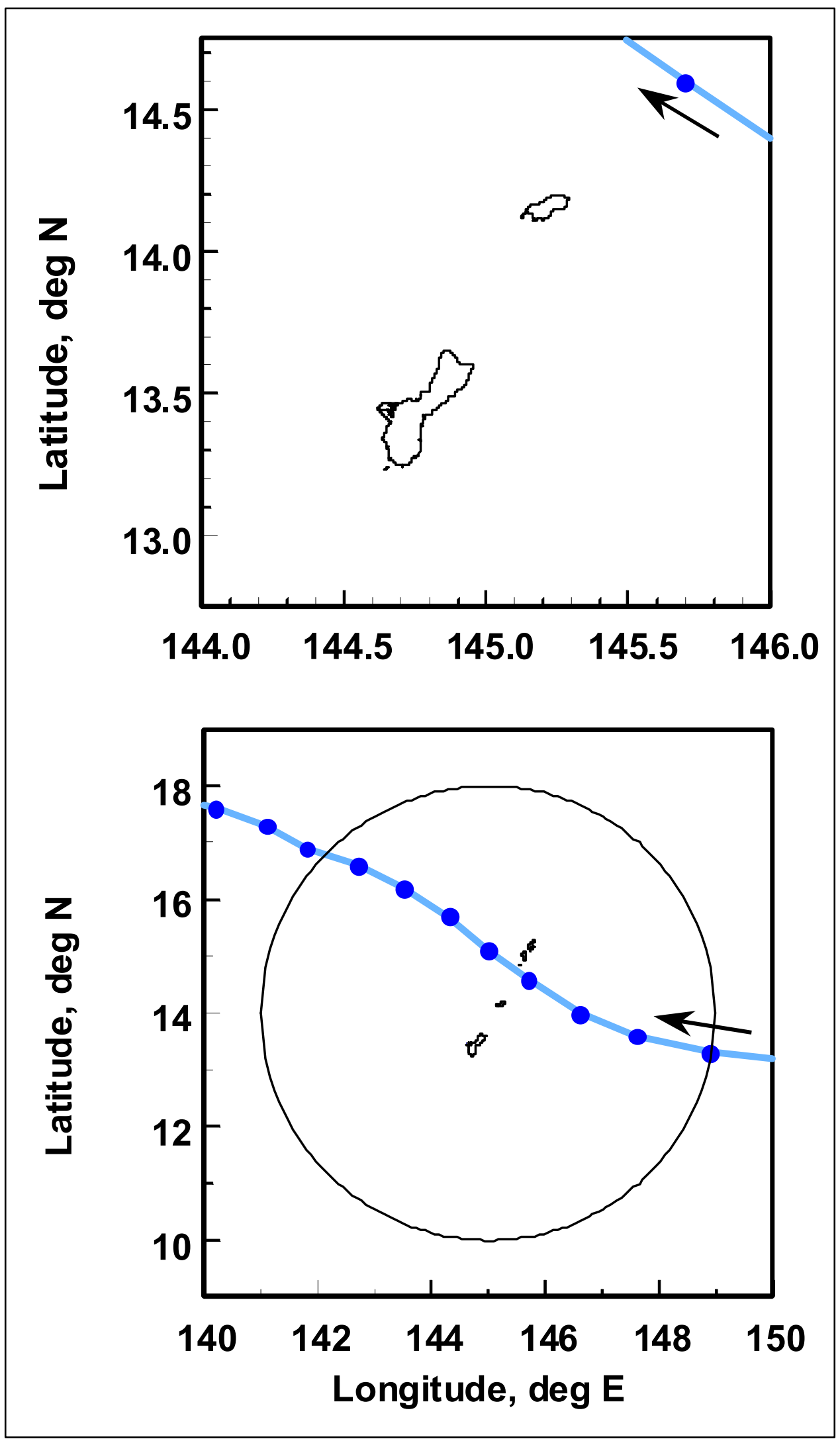

Figure A18. Storm track for Lynn (2187) 


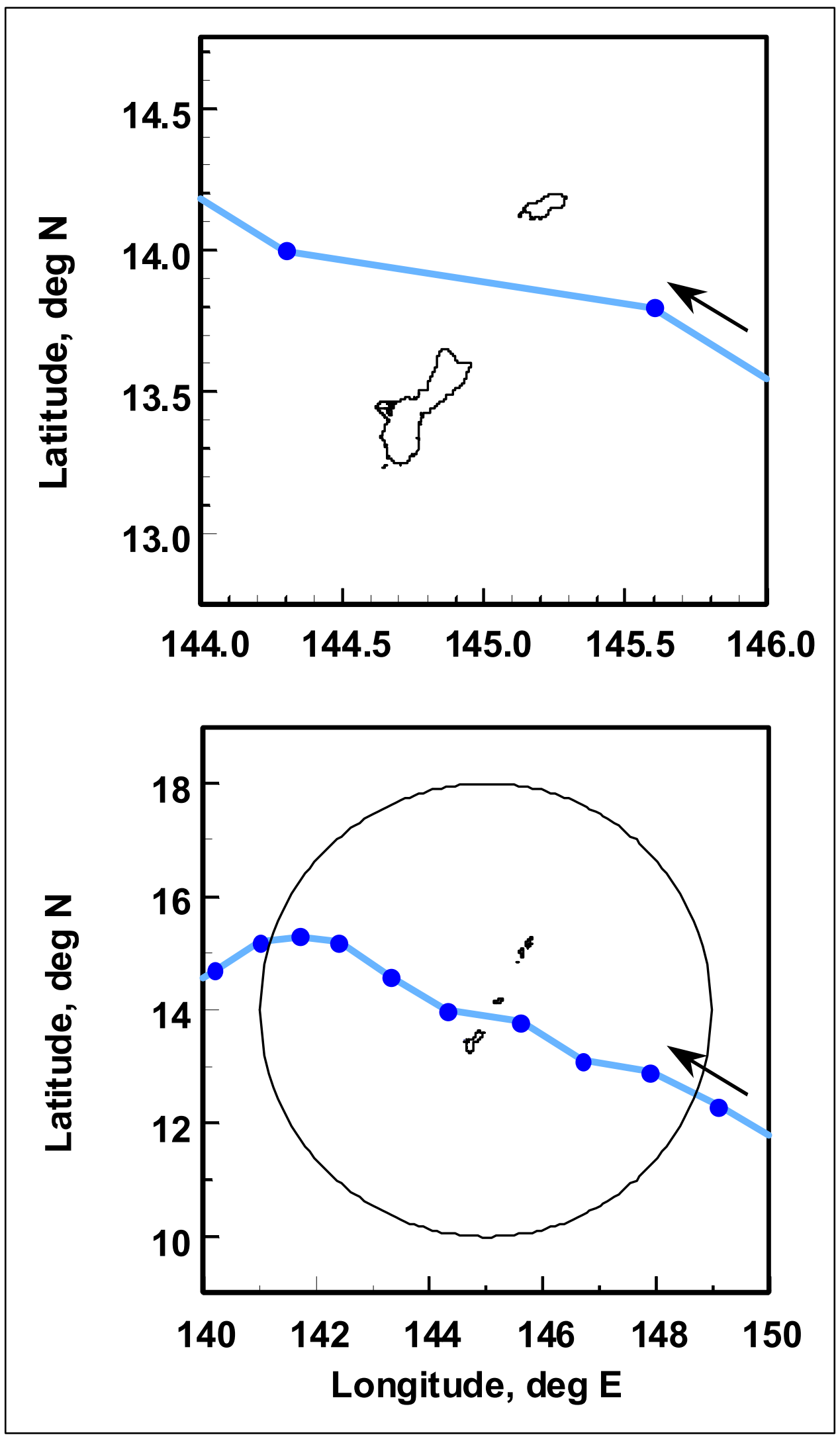

Figure A19. Storm track for Roy (0188) 


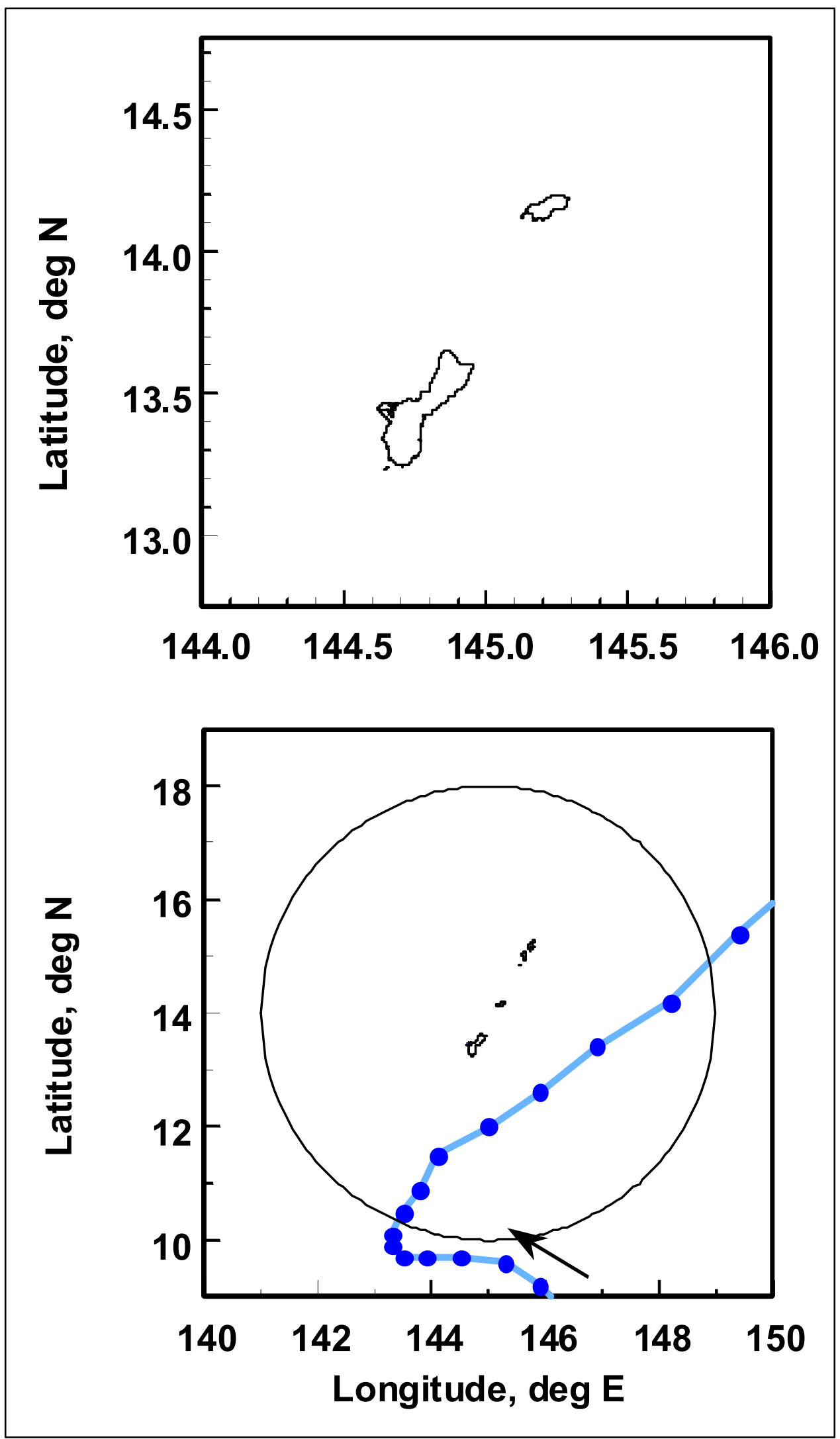

Figure A20. Storm track for Andy (0289) 


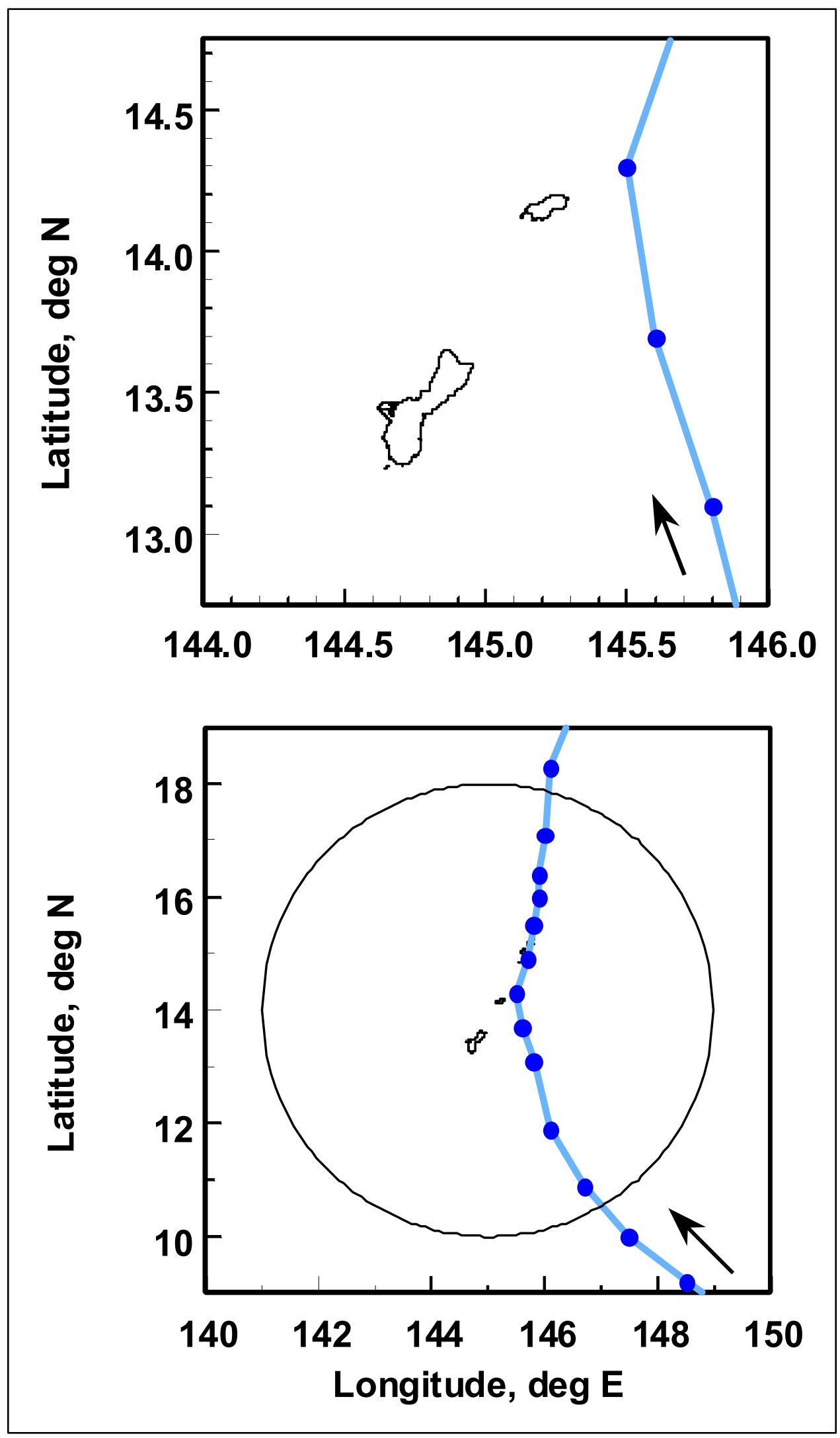

Figure A21. Storm track for Koryn (0190) 


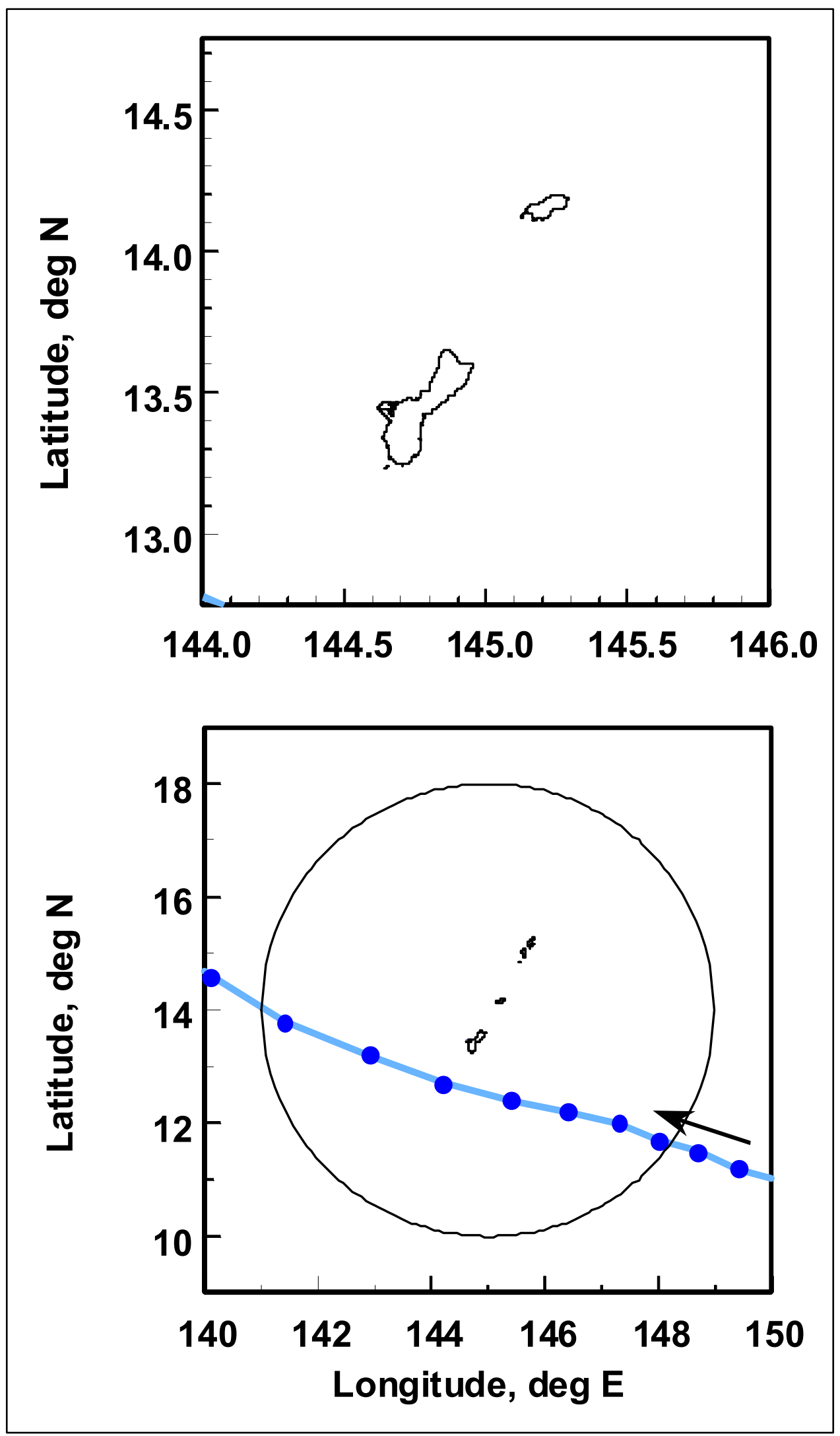

Figure A22. Storm track for Russ (3190) 


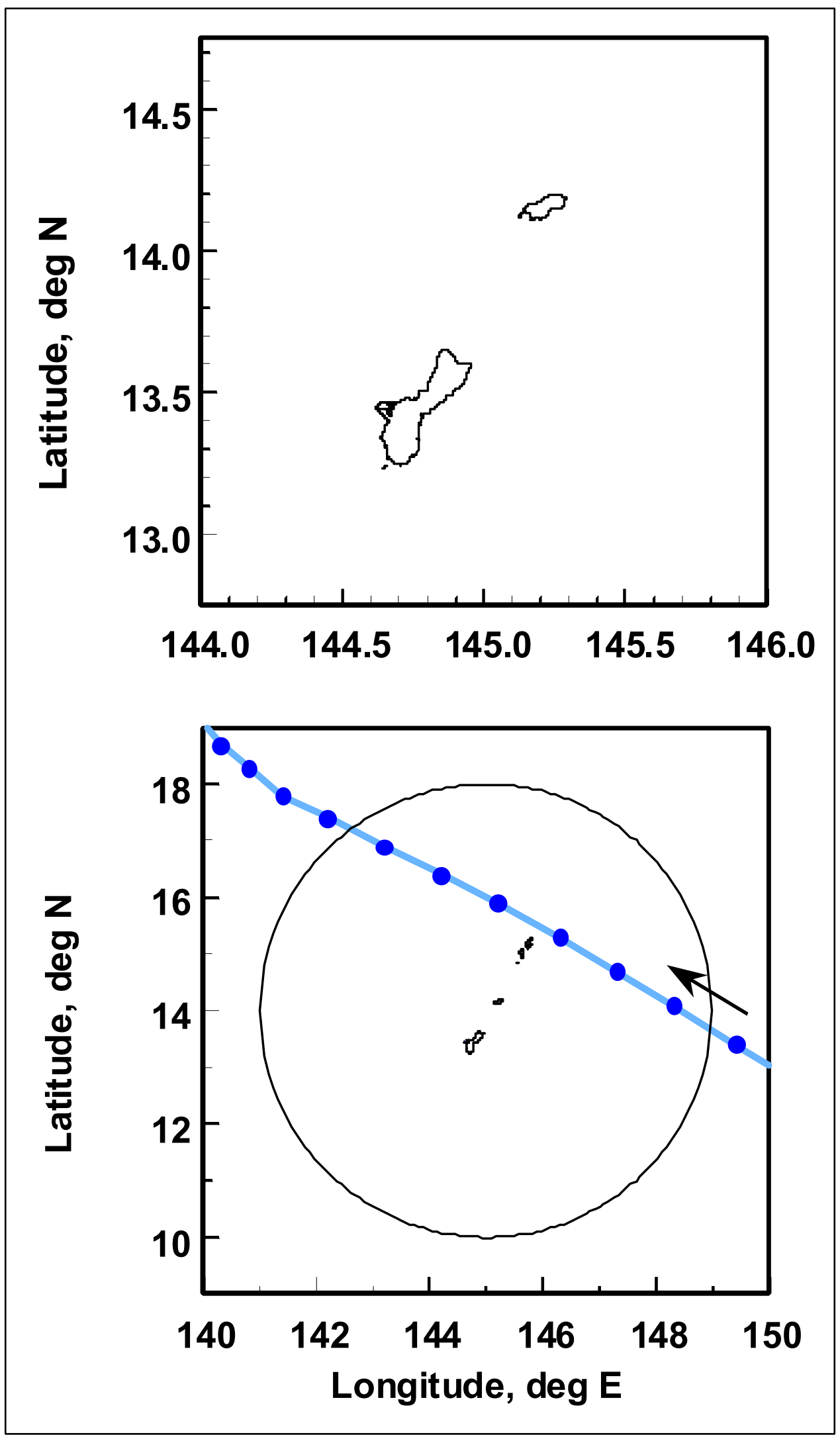

Figure A23. Storm track for Seth (2691) 


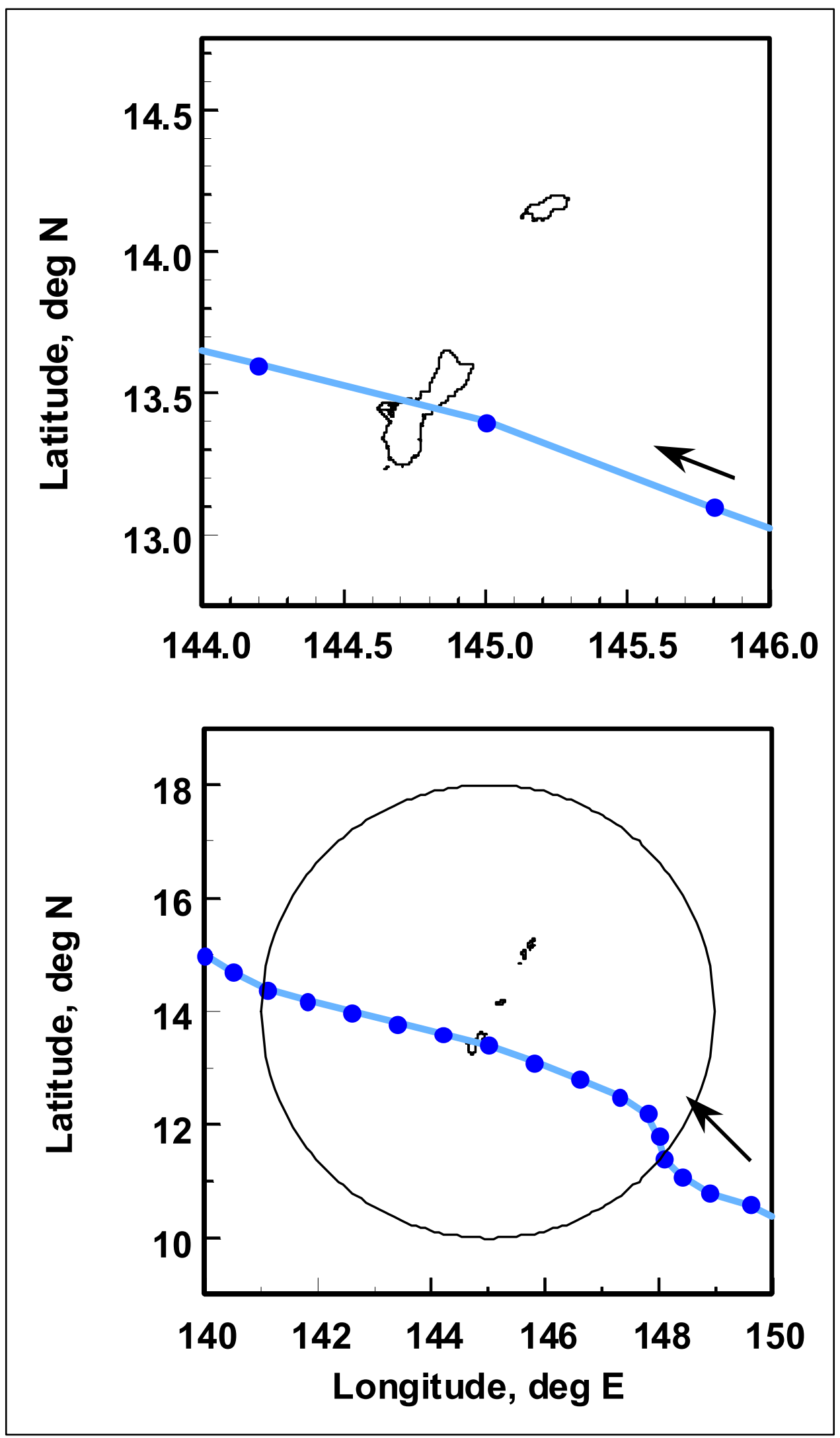

Figure A24. Storm track for Omar (1592) 


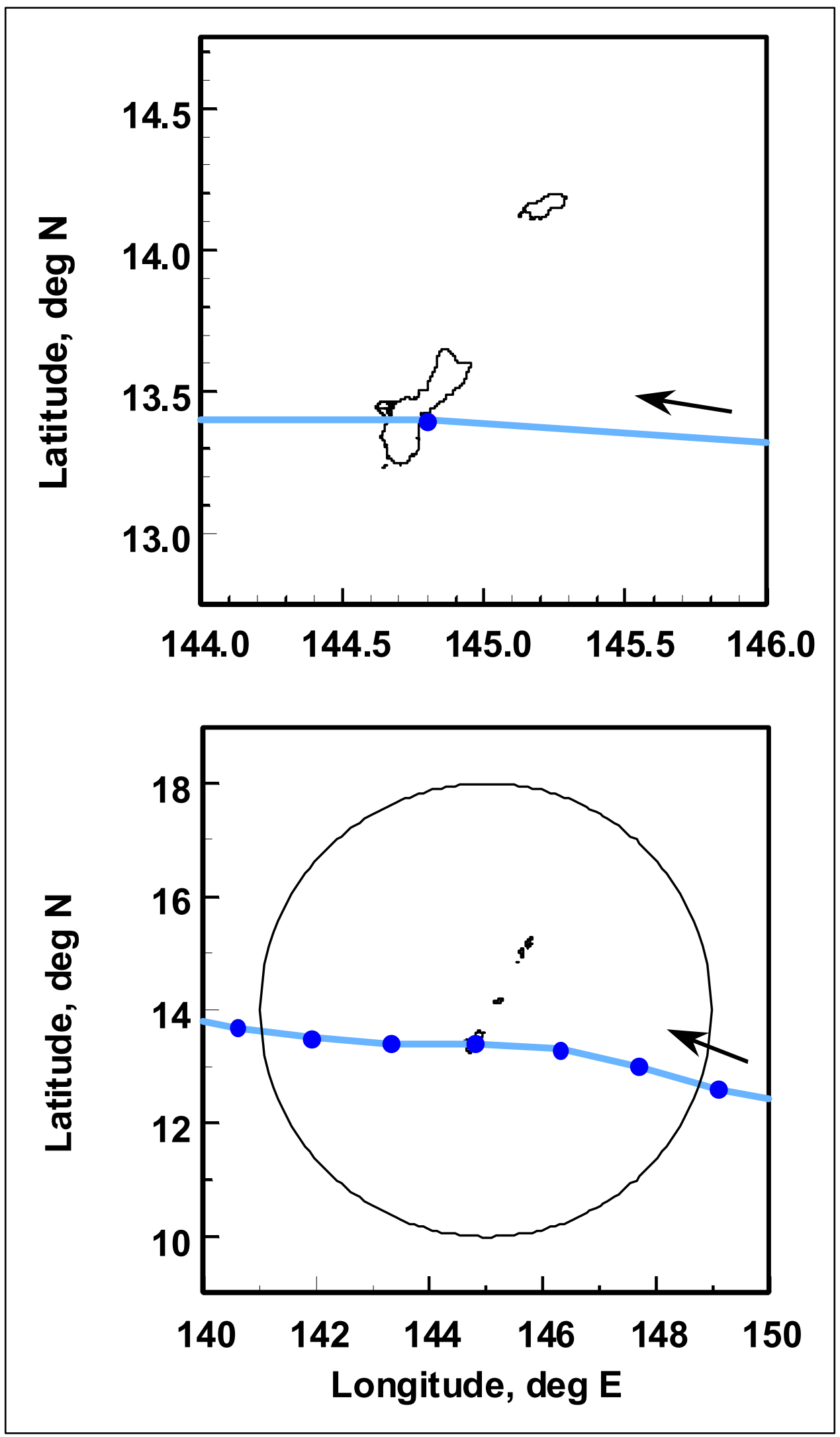

Figure A25. Storm track for Gay (3192) 


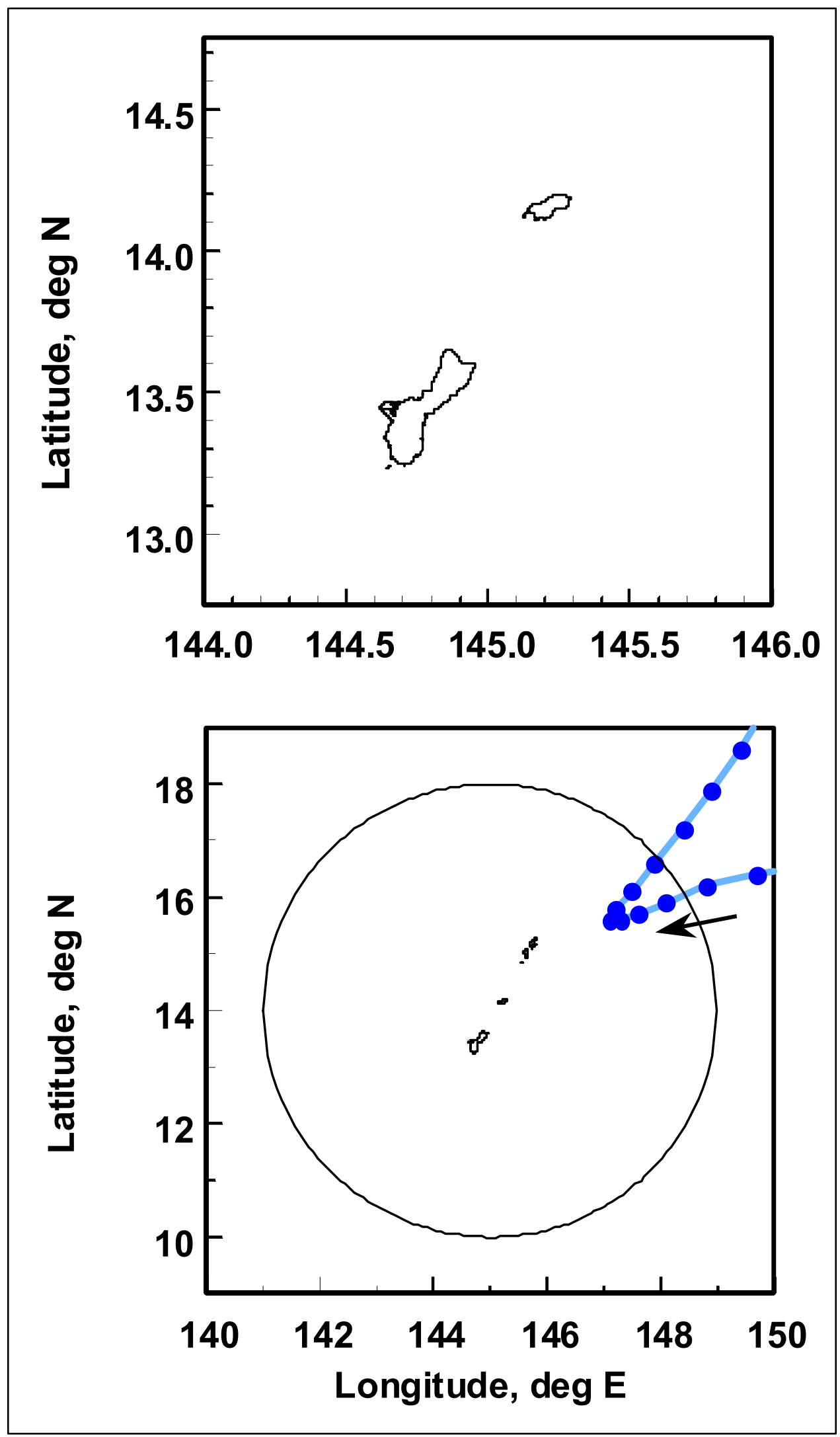

Figure A26. Storm track for Wilda (3594) 


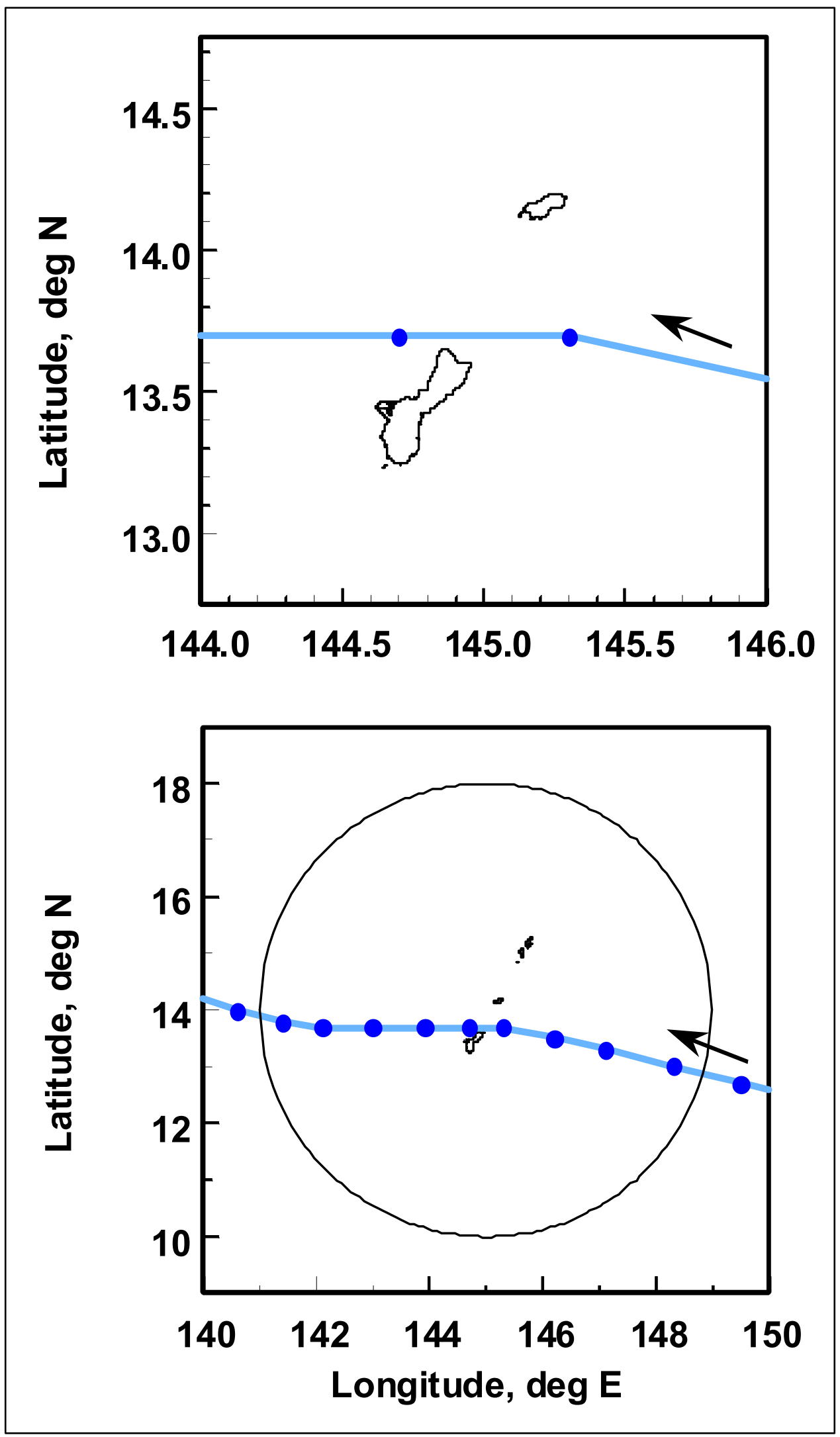

Figure A27. Storm track for Paka (0597) 


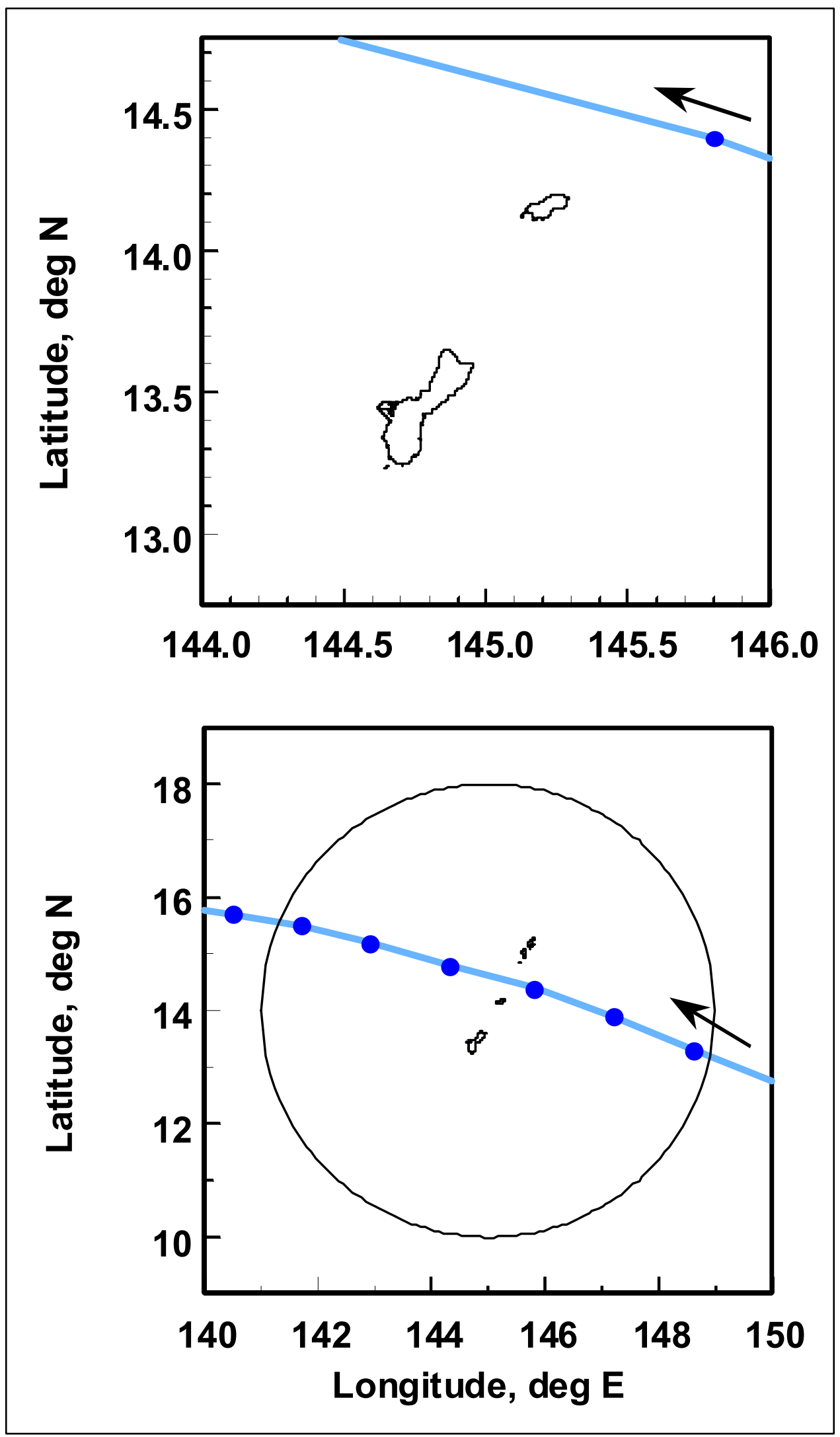

Figure A28. Storm track for Keith (2997) 


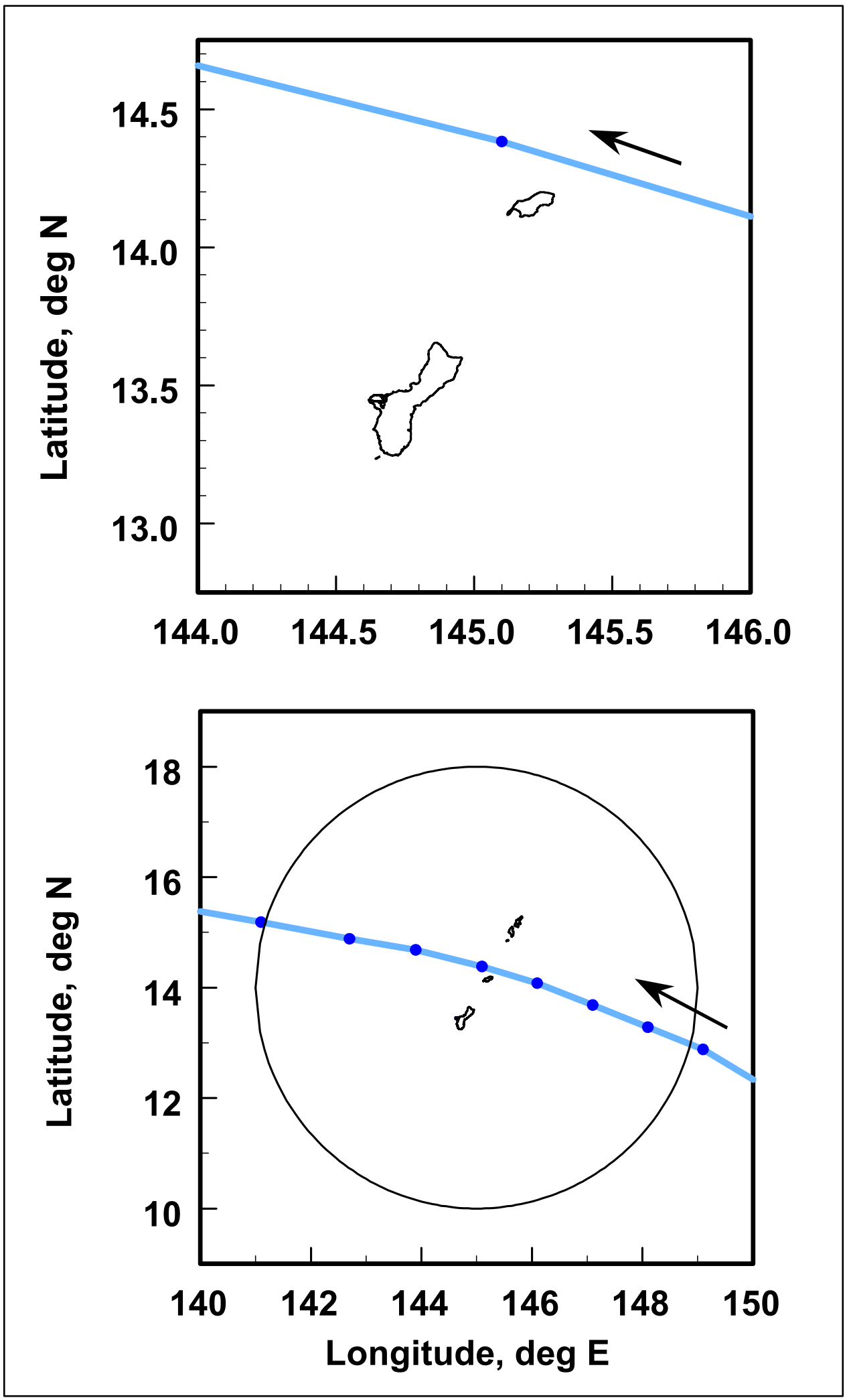

Figure A29. Storm track for hypothetical storm 1367 


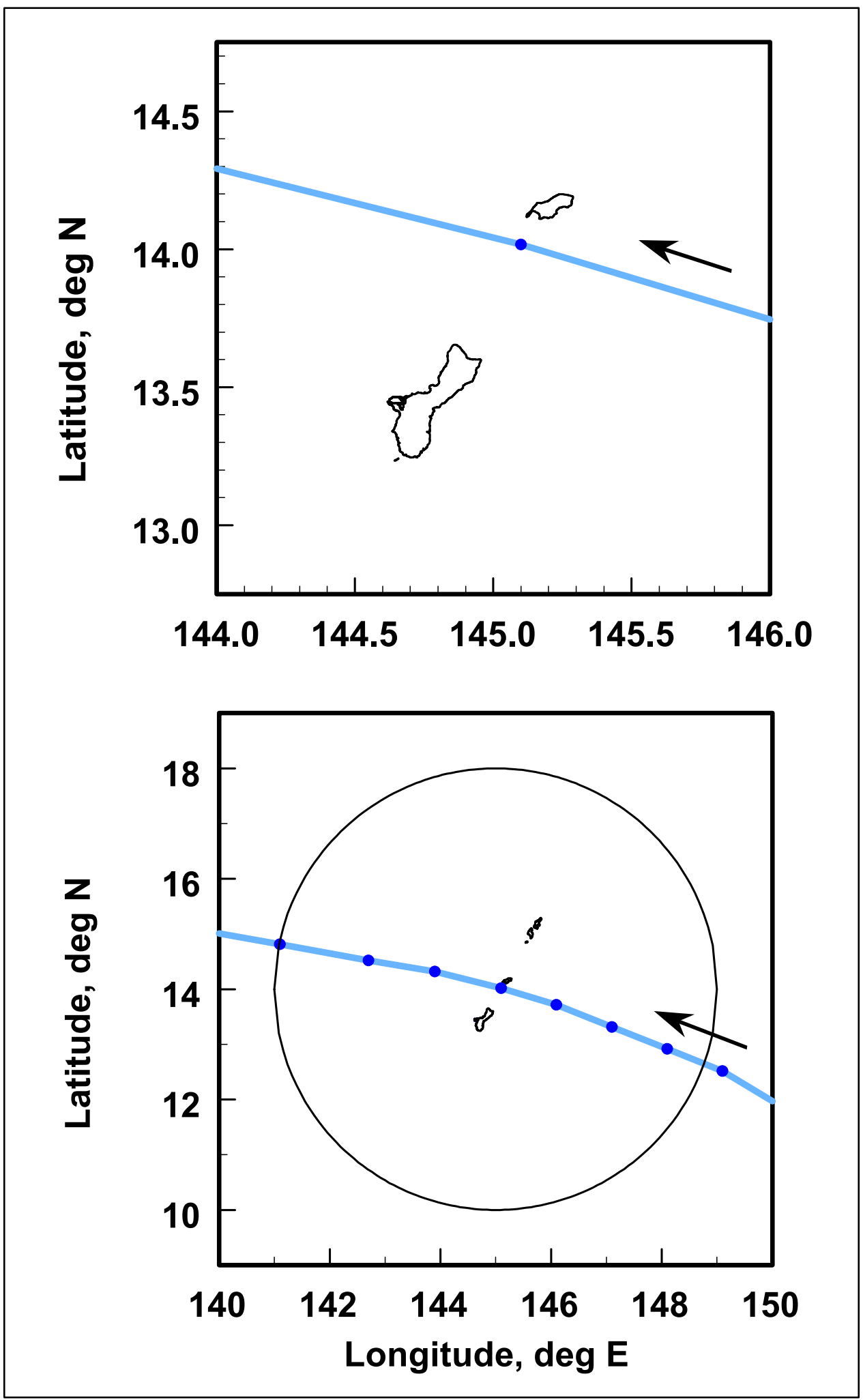

Figure A30. Storm track for hypothetical storm 4367 


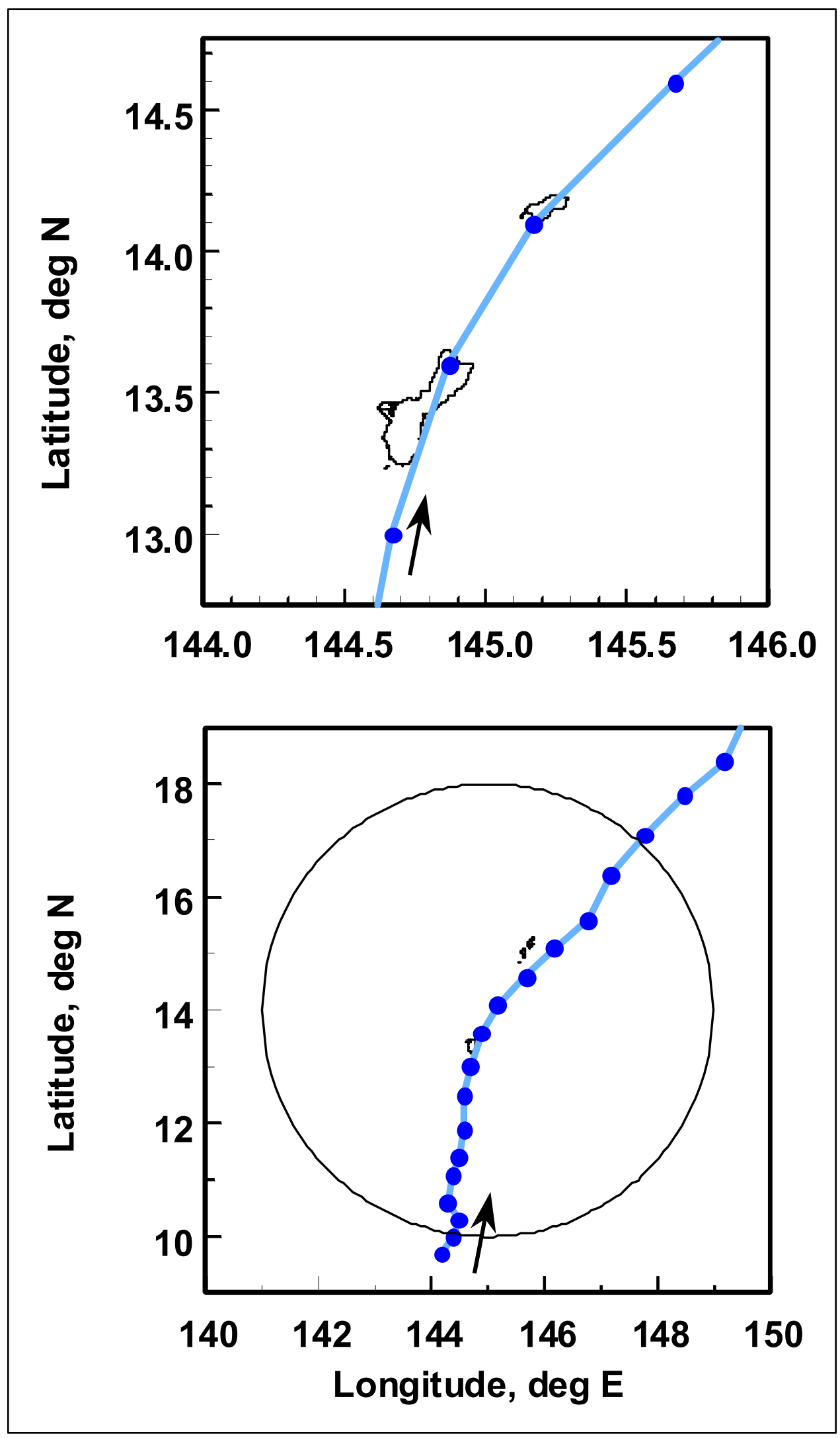

Figure A31. Storm track for hypothetical storm 5163 


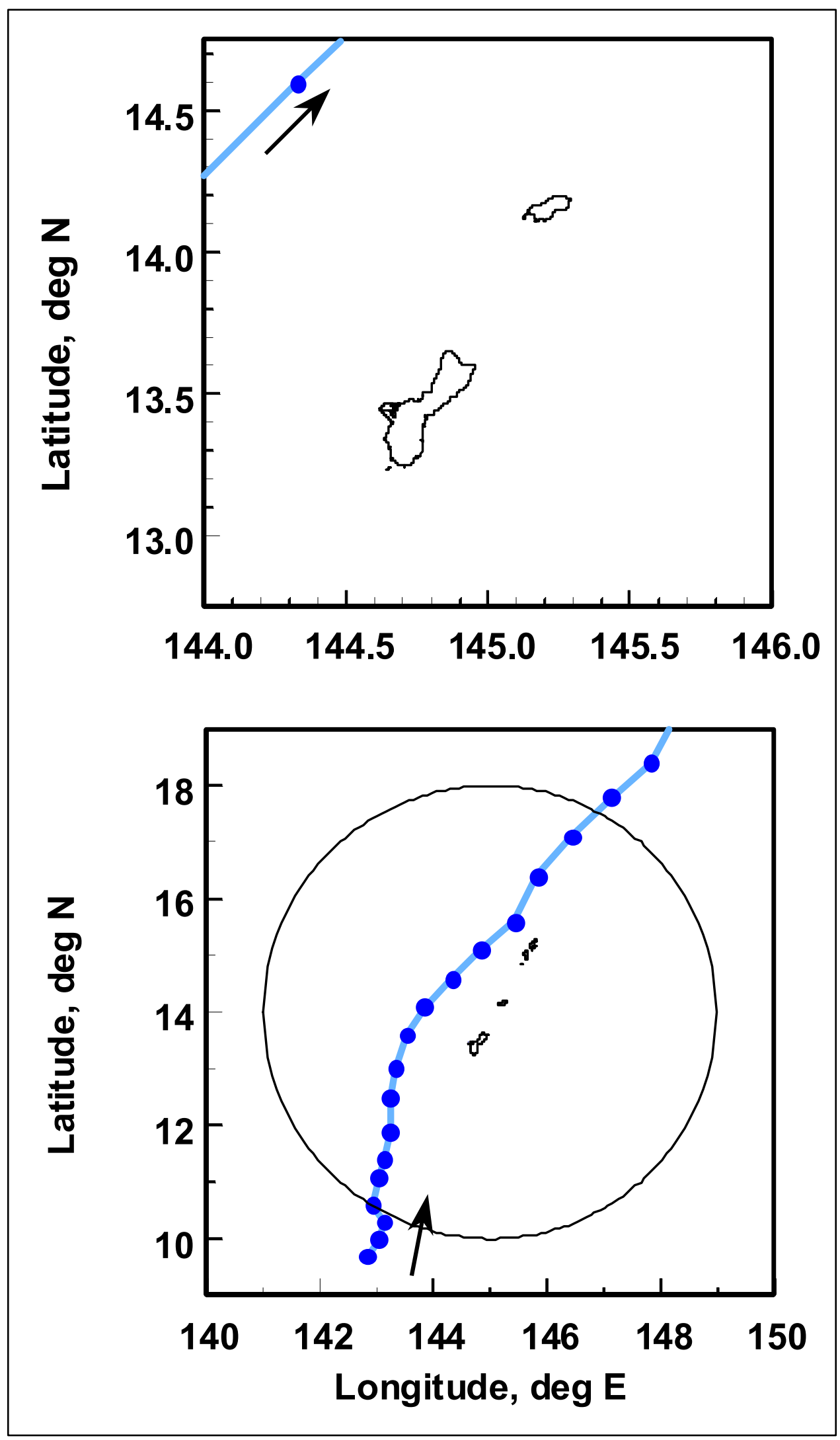

Figure A32. Storm track for hypothetical storm 6163 


\section{Appendix B Station Locations}

\begin{tabular}{|c|c|c|c|}
\hline \multicolumn{4}{|c|}{$\begin{array}{l}\text { Table B1 } \\
\text { Station Locations for Stage-Frequency Relationships }\end{array}$} \\
\hline Station & Description or Landmark & Latitude, $\operatorname{deg} N$ & Longitude, deg $\mathrm{E}$ \\
\hline R01 & Apra Harbor, Guam (tide gauge) & 13.4496 & 144.6265 \\
\hline \multicolumn{4}{|c|}{ Sasanhaya Embayment } \\
\hline R02 & $\begin{array}{l}\text { Southwest end of study coast } \\
\text { (Taipingot) }\end{array}$ & 14.1269 & 145.1319 \\
\hline R03 & & 14.1269 & 145.1340 \\
\hline R04 & & 14.1303 & 145.1344 \\
\hline R05 & & 14.1304 & 145.1365 \\
\hline R06 & & 14.1327 & 145.1356 \\
\hline R07 & & 14.1325 & 145.1375 \\
\hline R08 & & 14.1363 & 145.1387 \\
\hline R09 & & 14.1351 & 145.1407 \\
\hline $\mathrm{R} 10$ & Rota village, south coast & 14.1388 & 145.1429 \\
\hline R11 & & 14.1369 & 145.1433 \\
\hline $\mathrm{R} 12$ & & 14.1381 & 145.1466 \\
\hline $\mathrm{R} 13$ & & 14.1360 & 145.1467 \\
\hline R14 & & 14.1373 & 145.1504 \\
\hline $\mathrm{R} 15$ & & 14.1346 & 145.1546 \\
\hline $\mathrm{R} 16$ & Southeast end of study coast & 14.1335 & 145.1527 \\
\hline \multicolumn{4}{|c|}{ Northwest and north coasts } \\
\hline $\mathrm{R} 17$ & $\begin{array}{l}\text { Southwest end of study coast } \\
\text { (Taipingot) }\end{array}$ & 14.1305 & 145.1262 \\
\hline $\mathrm{R} 18$ & Anjota Island, south end & 14.1328 & 145.1261 \\
\hline $\mathrm{R} 19$ & & 14.1340 & 145.1255 \\
\hline R20 & Rota coast in lee of Anjota Island & 14.1332 & 145.1306 \\
\hline $\mathrm{R} 21$ & Anjota Island, north end & 14.1353 & 145.1289 \\
\hline $\mathrm{R} 22$ & & 14.1357 & 145.1330 \\
\hline $\mathrm{R} 23$ & & 14.1482 & 145.1307 \\
\hline
\end{tabular}




\begin{tabular}{||l|l|l|l||}
\hline \hline Table B1 (Concluded) & 14.1379 & 145.1359 \\
\hline \hline R24 & & 14.1411 & 145.1381 \\
\hline R25 & Rota village & 14.1440 & 145.1375 \\
\hline R26 & & 14.1438 & 145.1409 \\
\hline R27 & Rota village & 14.1472 & 145.1422 \\
\hline R28 & & 14.1505 & 145.1438 \\
\hline R29 & & 14.1519 & 145.1420 \\
\hline R30 & & 14.1539 & 145.1469 \\
\hline R31 & & 14.1590 & 145.1516 \\
\hline R32 & & 14.1597 & 145.1500 \\
\hline R33 & & 14.1634 & 145.1566 \\
\hline R34 & & 14.1679 & 145.1583 \\
\hline R35 & Tataacho Point & 14.1680 & 145.1647 \\
\hline R36 & & 14.1695 & 145.1652 \\
\hline R37 & & 14.1671 & 145.1715 \\
\hline R38 & & 14.1689 & 145.1788 \\
\hline R39 & & 14.1709 & 145.1847 \\
\hline R40 & & 14.1729 & 145.1845 \\
\hline R41 & & 14.1732 & 145.1896 \\
\hline R42 & & 14.1736 & 145.1950 \\
\hline R43 & & 14.1760 & 145.1950 \\
\hline R44 & & 14.1754 & 145.1995 \\
\hline R45 & Northeast end of study coast & \\
\hline & & & \\
\hline
\end{tabular}




\section{Appendix C Profile Locations Keyed To Station Locations}

\begin{tabular}{|c|c|c|c|c|c|}
\hline \multicolumn{6}{|c|}{$\begin{array}{l}\text { Table C1 } \\
\text { Profile Locations Keyed To Station Locations }\end{array}$} \\
\hline Profile & Station & Profile & Station & Profile & Station \\
\hline 1 & R02 & 30 & R28 & 59 & R38 \\
\hline 2 & R02/R04 & 31 & R28/R29 & 60 & R38 \\
\hline 3 & R04 & 32 & R29 & 61 & R38/R39 \\
\hline 4 & R06 & 33 & R29/R31 & 62 & R38/R39 \\
\hline 5 & R06 & 34 & R29/R31 & 63 & R39 \\
\hline 6 & R06/R08 & 35 & R31 & 64 & R39 \\
\hline 7 & R06/R08 & 36 & R31 & 65 & R39 \\
\hline 8 & R08 & 37 & R31/R32 & 66 & R39 \\
\hline 9 & R08 & 38 & R31/R32 & 67 & R39/R40 \\
\hline 10 & R10 & 39 & R31/R32 & 68 & R39/R40 \\
\hline 11 & R10 & 40 & R32 & 69 & R39/R40 \\
\hline 12 & R12 & 41 & R32 & 70 & $\mathrm{R} 40$ \\
\hline 13 & R12 & 42 & R32 & 71 & R40/R42 \\
\hline 14 & R12 & 43 & R32/R34 & 72 & R40/R42 \\
\hline 15 & R17 & 44 & R32/R34 & 73 & R40/R42 \\
\hline 16 & R17 & 45 & R32/R34 & 74 & R42 \\
\hline 17 & R17 & 46 & R34 & 75 & R42 \\
\hline 18 & $\mathrm{R} 20$ & 47 & R34 & 76 & R42/R43 \\
\hline 19 & R20 & 48 & R34/R35 & 77 & R42/R43 \\
\hline 20 & R22 & 49 & R35 & 78 & R43 \\
\hline 21 & R22 & 50 & R35/R36 & 79 & R43 \\
\hline 22 & R24 & 51 & R35/R36 & 80 & R43/R45 \\
\hline 23 & R24 & 52 & R35/R36 & 81 & R43/R45 \\
\hline 24 & R24 & 53 & R36 & 82 & R45 \\
\hline 25 & R25 & 54 & R36 & 83 & R45 \\
\hline 26 & R27 & 55 & R36 & 84 & R45 \\
\hline 27 & R27 & 56 & R36/R38 & 85 & R45 \\
\hline 28 & R27 & 57 & R36/R38 & 86 & R45 \\
\hline 29 & R28 & 58 & R36/R38 & 87 & R45 \\
\hline
\end{tabular}




\section{Appendix D Stage-Frequency Relationship Tables}

This appendix contains stage-frequency relationship values for profiles along the Rota coast. Maximum water level (including storm surge, wave ponding on the reef, and wave runup) and its standard deviation are given for eight return intervals for each profile. Maximum water level for Profiles 5 through 9 includes fictitious runup on an imaginary extension of the actual low bluff face, to be used subsequently with a low bluff methodology in mapping flood limits.

The tables also include maximum still water level (including storm surge, wave ponding on the reef, and nearshore wave setup) and its standard deviation for each profile and return interval. The reference datum is msl. 
Table D1

Return Period, Maximum Water Level, and Water Level Standard Deviation for Profile: Rota 1

\begin{tabular}{|c|c|c|c|c|}
\hline Return Period & Maximum & Water Level & \multicolumn{2}{|c|}{ Maximum Still Water Level } \\
\hline & Level, ft & std. Dev., ft & Level, ft & Std. Dev., ft \\
\hline 2 & 19.7 & 8.9 & 3.6 & 1.6 \\
\hline 5 & 41.7 & 1.2 & 7.5 & 0.5 \\
\hline 10 & 48.5 & 2.8 & 9.1 & 0.6 \\
\hline 25 & 56.5 & 3.7 & 10.7 & 0.7 \\
\hline 50 & 63.5 & 5.9 & 11.8 & 0.9 \\
\hline 75 & 67.6 & 6.1 & 12.4 & 0.9 \\
\hline 100 & 69.7 & 6.8 & 12.7 & 1.1 \\
\hline 500 & 77.5 & 8.4 & 13.9 & 1.3 \\
\hline
\end{tabular}

Table D2

Return Period, Maximum Water Level, and Water Level Standard Deviation for Profile: Rota 2

$\begin{array}{rlccc}\begin{array}{l}\text { Return Period } \\ \text { yr }\end{array} & \begin{array}{c}\text { Maximum Water Level } \\ \text { Level, ft }\end{array} & \begin{array}{c}\text { Maximum Stil Water Level } \\ \text { Level, ft }\end{array} \\ 2 & 18.9 & 8.2 & 3.6 & 1.6 \\ 5 & 38.7 & 1.5 & 7.6 & 0.4 \\ 10 & 46.7 & 3.1 & 9.2 & 0.6 \\ 25 & 54.4 & 3.5 & 10.7 & 0.7 \\ 50 & 61.3 & 6.0 & 11.8 & 0.9 \\ 75 & 65.6 & 6.1 & 12.4 & 0.9 \\ 100 & 67.7 & 6.7 & 12.7 & 1.1 \\ 500 & 75.5 & 8.3 & 13.9 & 1.3\end{array}$

Table D3

Return Period, Maximum Water Level, and Water Level Standard Deviation for Profile: Rota 3

\begin{tabular}{|c|c|c|c|c|}
\hline Return Period & Maximum & Water Level & \multicolumn{2}{|c|}{ Maximum Still Water Level } \\
\hline yr & Level, ft & std. Dev., ft & Level, ft & Std. Dev., ft \\
\hline 2 & 11.9 & 4.6 & 3.6 & 1.6 \\
\hline 5 & 24.7 & 1.1 & 7.6 & 0.5 \\
\hline 10 & 30.4 & 2.1 & 9.2 & 0.6 \\
\hline 25 & 35.9 & 2.2 & 10.8 & 0.7 \\
\hline 50 & 40.6 & 4.2 & 12.0 & 1.0 \\
\hline 75 & 43.0 & 4.6 & 12.6 & 1.0 \\
\hline 100 & 44.3 & 5.1 & 12.9 & 1.1 \\
\hline 500 & 49.5 & 6.4 & 14.2 & 1.4 \\
\hline
\end{tabular}

Table D4

Return Period, Maximum Water Level, and Water Level Standard Deviation for Profile: Rota 4

\begin{tabular}{rlccc} 
Return Period & \multicolumn{2}{c}{ Maximum Water Level } & \multicolumn{2}{c}{ Maximum Still Water Level } \\
yr & Level, ft & Std. Dev., ft & Level, ft & Std. Dev., ft \\
2 & 20.1 & 6.9 & 3.6 & 1.6 \\
5 & 33.9 & 0.5 & 7.4 & 0.4 \\
10 & 36.8 & 1.2 & 9.1 & 0.6 \\
25 & 40.0 & 1.5 & 10.7 & 0.6 \\
50 & 43.1 & 2.7 & 11.7 & 0.9 \\
75 & 44.9 & 2.7 & 12.3 & 0.9 \\
100 & 45.9 & 3.0 & 12.6 & 1.0 \\
500 & 49.3 & 3.7 & 13.8 & 1.3
\end{tabular}


Table D5

Return Period, Maximum Water Level, and Water Level Standard Deviation for Profile: Rota 5

\begin{tabular}{rrrrr} 
Return Period & \multicolumn{2}{c}{ Maximum Water Level } & \multicolumn{2}{c}{ Maximum Still Water Level } \\
yr & Level, ft Std. Dev., ft & Level, ft & Std. Dev., ft \\
2 & 30.3 & 12.0 & 3.7 & 1.6 \\
5 & 56.3 & 1.2 & 7.6 & 0.4 \\
10 & 63.3 & 2.8 & 9.2 & 0.6 \\
25 & 70.3 & 4.0 & 10.9 & 0.6 \\
50 & 78.9 & 7.3 & 11.9 & 0.9 \\
75 & 84.0 & 7.3 & 12.6 & 0.9 \\
100 & 86.5 & 8.0 & 12.9 & 1.0 \\
500 & 95.8 & 9.9 & 14.0 & 1.3
\end{tabular}

\section{Table D6}

Return Period, Maximum Water Level, and Water Level Standard Deviation for Profile: Rota 6

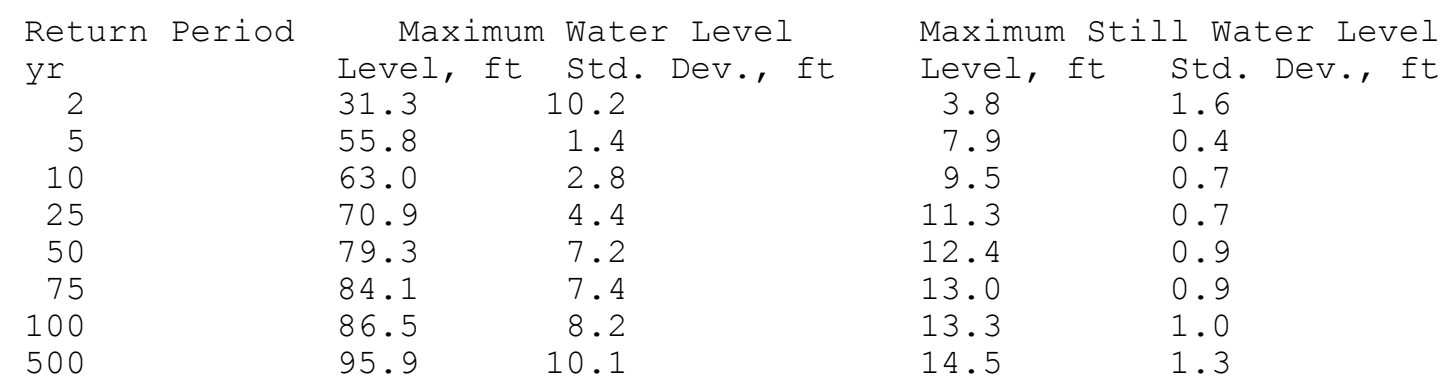

\section{Table D7}

Return Period, Maximum Water Level, and Water Level Standard Deviation for Profile: Rota 7

$\begin{array}{ccccc}\begin{array}{c}\text { Return Period } \\ \text { yr }\end{array} & \begin{array}{c}\text { Maximum Water Level } \\ \text { Level, ft Std. Dev, ft }\end{array} & \begin{array}{c}\text { Maximum Still Water Level } \\ \text { Level, ft }\end{array} \\ 2 & 31.2 & 10.6 & 3.7 & 1.5 \\ 5 & 55.6 & 1.0 & 7.7 & 0.4 \\ 10 & 61.6 & 2.7 & 9.2 & 0.7 \\ 25 & 69.9 & 3.9 & 11.1 & 0.7 \\ 50 & 78.7 & 7.5 & 12.3 & 0.9 \\ 75 & 83.8 & 8.4 & 12.9 & 1.0 \\ 100 & 86.4 & 9.6 & 13.2 & 1.1 \\ 500 & 96.1 & 11.9 & 14.4 & 1.3\end{array}$

Table D8

Return Period, Maximum Water Level, and Water Level Standard Deviation for Profile: Rota 8

\begin{tabular}{rrrrr} 
Return Period & \multicolumn{2}{c}{ Maximum Water Level } & \multicolumn{2}{c}{ Maximum Still Water Level } \\
yr & Level, ft & Std. Dev., ft & Level, ft & Std. Dev., ft \\
2 & 30.2 & 11.2 & 3.5 & 1.5 \\
5 & 56.4 & 0.9 & 7.6 & 0.3 \\
10 & 61.0 & 2.5 & 9.0 & 0.7 \\
25 & 70.2 & 4.1 & 10.9 & 0.7 \\
50 & 79.0 & 7.2 & 12.0 & 0.8 \\
75 & 84.0 & 8.1 & 12.5 & 0.9 \\
100 & 86.4 & 9.3 & 12.8 & 1.0 \\
500 & 95.8 & 11.5 & 13.9 & 1.2
\end{tabular}


Table D9

Return Period, Maximum Water Level, and Water Level Standard Deviation for Profile: Rota 9

\begin{tabular}{rlllcl} 
Return Period & \multicolumn{2}{c}{ Maximum Water Level } & \multicolumn{2}{c}{ Maximum Still Water Level } \\
yr & Level, ft & Std. Dev., ft & Level, ft & Std. Dev., ft \\
2 & 17.6 & 6.0 & 3.4 & 1.4 \\
5 & 32.6 & 0.5 & 7.6 & 0.4 \\
10 & 35.8 & 1.9 & 9.1 & 0.6 \\
25 & 41.8 & 2.5 & 10.8 & 0.7 \\
50 & 46.9 & 4.3 & 11.8 & 0.8 \\
75 & 49.9 & 4.7 & 12.4 & 0.8 \\
100 & 51.4 & 5.4 & 12.7 & 1.0 \\
500 & 56.8 & 6.6 & & 13.7 & 1.2
\end{tabular}

Table D10

Return Period, Maximum Water Level, and Water Level Standard Deviation for Profile: Rota 10

\begin{tabular}{rlccc} 
Return Period & \multicolumn{2}{c}{ Maximum Water Level } & \multicolumn{2}{c}{ Maximum Still Water Level } \\
yr & Level, ft & Std. Dev., ft & Level, ft & Std. Dev., ft \\
2 & 10.9 & 3.7 & 3.3 & 1.3 \\
5 & 17.9 & 0.3 & 7.6 & 0.4 \\
10 & 18.9 & 0.5 & 8.7 & 0.5 \\
25 & 21.4 & 1.4 & 10.4 & 0.8 \\
50 & 23.6 & 1.8 & 11.3 & 0.6 \\
75 & 24.9 & 2.0 & 11.8 & 0.7 \\
100 & 25.5 & 2.3 & 12.0 & 0.8 \\
500 & 27.9 & 2.8 & 12.9 & 1.0
\end{tabular}

Table D11

Return Period, Maximum Water Level, and Water Level Standard Deviation for Profile: Rota 11

\begin{tabular}{rllcrl} 
Return Period & \multicolumn{2}{c}{ Maximum Water Level } & \multicolumn{2}{c}{ Maximum Still Water Level } \\
yr & Level, ft & Std. Dev., ft & Level, ft & Std. Dev., ft \\
2 & 15.7 & 4.9 & 3.3 & 1.3 \\
5 & 24.0 & 0.2 & 7.6 & 0.4 \\
10 & 25.0 & 0.7 & 8.7 & 0.5 \\
25 & 29.0 & 1.7 & 10.4 & 0.7 \\
50 & 31.4 & 1.7 & 11.3 & 0.6 \\
75 & 32.7 & 1.9 & 11.7 & 0.7 \\
100 & 33.3 & 2.2 & 12.0 & 0.8 \\
500 & 35.6 & 2.8 & 12.9 & 1.0
\end{tabular}

Table D12

Return Period, Maximum Water Level, and Water Level Standard Deviation for Profile: Rota 12

\begin{tabular}{rllcc} 
Return Period & \multicolumn{2}{c}{ Maximum Water Level } & \multicolumn{2}{c}{ Maximum Still Water Level } \\
yr & Level, ft & Std. Dev., ft & Level, ft & Std. Dev., ft \\
2 & 16.6 & 5.2 & 3.6 & 1.3 \\
5 & 25.2 & 0.2 & 8.0 & 0.5 \\
10 & 25.9 & 0.3 & 9.2 & 0.4 \\
25 & 26.8 & 0.5 & 10.6 & 0.6 \\
50 & 27.7 & 0.7 & 11.5 & 0.7 \\
75 & 28.3 & 1.0 & 12.1 & 0.8 \\
100 & 28.6 & 1.3 & 12.4 & 1.0 \\
500 & 29.9 & 1.6 & 13.6 & 1.2
\end{tabular}


Table D13

Return Period, Maximum Water Level, and Water Level Standard Deviation for Profile: Rota 13

\begin{tabular}{|c|c|c|c|c|}
\hline Return Period & Maximum & Water Level & \multicolumn{2}{|c|}{ Maximum Still Water Level } \\
\hline & Level, ft & Std. Dev., ft & Level, ft & Std. Dev., ft \\
\hline $\begin{array}{l}2 \\
5\end{array}$ & 9.7 & 3.3 & 3.4 & 1.2 \\
\hline 5 & 20.1 & 0.6 & 7.8 & 0.5 \\
\hline 10 & 21.3 & 0.5 & 8.9 & 0.4 \\
\hline 25 & 23.8 & 1.3 & 10.2 & 0.6 \\
\hline 50 & 25.6 & 1.5 & 11.0 & 0.7 \\
\hline 75 & 26.9 & 1.6 & 11.6 & 0.8 \\
\hline 100 & 27.5 & 1.9 & 11.9 & 0.9 \\
\hline 500 & 29.6 & 2.3 & 13.1 & 1.1 \\
\hline
\end{tabular}

\section{Table D14}

Return Period, Maximum Water Level, and Water Level Standard Deviation for Profile: Rota 14

\begin{tabular}{llccc}
$\begin{array}{l}\text { Return Period } \\
\text { yr }\end{array}$ & $\begin{array}{c}\text { Maximum Water Level } \\
\text { Level, ft }\end{array}$ Std. Dev, ft & \multicolumn{2}{c}{$\begin{array}{c}\text { Maximum Stil Water Level } \\
\text { Level, ft }\end{array}$} \\
2 & 17.1 & 5.3 & 3.5 & 1.2 \\
5 & 24.9 & 0.3 & 7.8 & 0.5 \\
10 & 25.8 & 0.4 & 9.0 & 0.4 \\
25 & 27.2 & 0.8 & 10.3 & 0.6 \\
50 & 28.3 & 0.9 & 11.1 & 0.7 \\
75 & 29.1 & 1.0 & 11.6 & 0.8 \\
100 & 29.4 & 1.2 & 11.9 & 1.0 \\
500 & 30.8 & 1.5 & 13.2 & 1.2
\end{tabular}

\section{Table D15}

Return Period, Maximum Water Level, and Water Level Standard Deviation for Profile: Rota 15

\begin{tabular}{ccccc}
$\begin{array}{c}\text { Return Period } \\
\text { yr }\end{array}$ & $\begin{array}{c}\text { Maximum Water Level } \\
\text { Level, ft }\end{array}$ Std. Dev., ft & \multicolumn{2}{c}{$\begin{array}{c}\text { Maximum Stil Water Level } \\
\text { Level, ft }\end{array}$} \\
2 & 9.7 & 3.1 & 3.3 & 1.2 \\
5 & 19.0 & 1.9 & 7.2 & 0.6 \\
10 & 27.0 & 2.5 & 8.7 & 0.5 \\
25 & 31.7 & 1.9 & 9.6 & 0.3 \\
50 & 34.1 & 2.0 & 10.2 & 0.5 \\
75 & 35.4 & 2.2 & 10.5 & 0.6 \\
100 & 36.0 & 2.5 & 10.7 & 0.7 \\
500 & 38.7 & 3.1 & 11.5 & 0.8
\end{tabular}

\section{Table D16}

Return Period, Maximum Water Level, and Water Level Standard Deviation for Profile: Rota 16

\begin{tabular}{ccccc}
$\begin{array}{c}\text { Return Period } \\
\text { yr }\end{array}$ & $\begin{array}{c}\text { Maximum } \\
\text { Level, ft }\end{array}$ Std. Dev., ft & \multicolumn{2}{c}{ Maximum Still Water Level } \\
Level, ft Std. Dev., ft \\
2 & 9.1 & 3.1 & 3.3 & 1.2 \\
5 & 18.5 & 1.3 & 7.1 & 0.5 \\
10 & 21.0 & 0.5 & 8.6 & 0.4 \\
25 & 22.0 & 0.4 & 9.5 & 0.4 \\
50 & 22.7 & 0.5 & 10.0 & 0.4 \\
75 & 23.2 & 0.8 & 10.3 & 0.5 \\
100 & 23.4 & 1.0 & 10.4 & 0.6 \\
500 & 24.4 & 1.2 & 11.2 & 0.7
\end{tabular}


Table D17

Return Period, Maximum Water Level, and Water Level Standard Deviation for Profile: Rota 17

\begin{tabular}{rllcc} 
Return Period & \multicolumn{2}{c}{ Maximum Water Level } & \multicolumn{2}{c}{ Maximum Still Water Level } \\
yr & Level, ft & Std. Dev., ft & Level, ft & Std. Dev., ft \\
2 & 10.0 & 2.9 & 3.3 & 1.2 \\
5 & 19.5 & 1.0 & 7.1 & 0.5 \\
10 & 21.2 & 0.4 & 8.5 & 0.4 \\
25 & 22.0 & 0.3 & 9.4 & 0.4 \\
50 & 22.5 & 0.4 & 9.9 & 0.4 \\
75 & 22.9 & 0.6 & 10.2 & 0.5 \\
100 & 23.1 & 0.7 & 10.4 & 0.6 \\
500 & 24.1 & 0.8 & 11.1 & 0.7
\end{tabular}

\section{Table D18}

Return Period, Maximum Water Level, and Water Level Standard Deviation for Profile: Rota 18

\begin{tabular}{clccc}
$\begin{array}{l}\text { Return Period } \\
\text { yr }\end{array}$ & $\begin{array}{c}\text { Maximum } \\
\text { Level, ft }\end{array}$ Std. Dev., ft & \multicolumn{2}{c}{ Maximum Still Water Level } \\
Level, ft & Std. Dev., ft \\
2 & 11.9 & 4.0 & 3.2 & 1.2 \\
5 & 20.8 & 0.3 & 7.0 & 0.5 \\
10 & 21.5 & 0.2 & 8.4 & 0.4 \\
25 & 22.2 & 0.3 & 9.3 & 0.3 \\
50 & 22.6 & 0.4 & 9.7 & 0.4 \\
75 & 23.0 & 0.7 & 10.0 & 0.4 \\
100 & 23.2 & 0.9 & 10.2 & 0.5 \\
500 & 24.8 & 1.1 & 10.8 & 0.6
\end{tabular}

\section{Table D19}

Return Period, Maximum Water Level, and Water Level Standard Deviation for Profile: Rota 19

$\begin{array}{ccccc}\begin{array}{c}\text { Return Period } \\ \text { yr }\end{array} & \begin{array}{c}\text { Maximum } \\ \text { Level, ft }\end{array} & \text { Std. Der Level } & \text { Maximum Stil Water Level } \\ 2 & 8.0 & 2.5 & \text { Level, ft } & \text { Std. Dev., ft } \\ 5 & 13.7 & 0.4 & 3.1 & 1.1 \\ 10 & 14.7 & 0.3 & 6.5 & 0.5 \\ 25 & 15.4 & 0.3 & 7.8 & 0.4 \\ 50 & 15.9 & 0.4 & 8.6 & 0.3 \\ 75 & 16.1 & 0.5 & 9.1 & 0.4 \\ 100 & 16.3 & 0.6 & 9.3 & 0.4 \\ 500 & 17.1 & 0.8 & 9.5 & 0.5 \\ & & & 10.1 & 0.6\end{array}$

Table D20

Return Period, Maximum Water Level, and Water Level Standard Deviation for Profile: Rota 20

\begin{tabular}{rcccc}
$\begin{array}{l}\text { Return Period } \\
\text { yr }\end{array}$ & $\begin{array}{c}\text { Maximum } \\
\text { Level, ft }\end{array}$ Std. Dev., ft & \multicolumn{2}{c}{ Maximum Still Water Level } \\
Level, ft & Std. Dev., ft \\
2 & 9.4 & 2.1 & 3.2 & 1.1 \\
5 & 13.1 & 0.8 & 6.8 & 0.5 \\
10 & 15.6 & 0.8 & 8.3 & 0.5 \\
25 & 16.8 & 0.4 & 9.1 & 0.3 \\
50 & 17.4 & 0.6 & 9.5 & 0.4 \\
75 & 17.8 & 0.6 & 9.8 & 0.4 \\
100 & 18.1 & 0.8 & 10.0 & 0.5 \\
500 & 18.9 & 0.9 & 10.5 & 0.6
\end{tabular}


Table D21

Return Period, Maximum Water Level, and Water Level Standard Deviation for Profile: Rota 21

$\begin{array}{rlccc}\begin{array}{l}\text { Return Period } \\ \text { yr }\end{array} & \begin{array}{c}\text { Maximum Water Level } \\ \text { Level, ft }\end{array} & \begin{array}{c}\text { Maximum Stil Water Level } \\ \text { Std. Dev., ft }\end{array} \\ 2 & 11.7 & 2.6 & 3.3 & 1.1 \\ 5 & 14.4 & 0.4 & 7.1 & 0.5 \\ 10 & 16.1 & 0.7 & 8.7 & 0.5 \\ 25 & 17.8 & 0.8 & 9.6 & 0.3 \\ 50 & 19.0 & 1.1 & 10.0 & 0.4 \\ 75 & 19.8 & 1.2 & 10.3 & 0.4 \\ 100 & 20.2 & 1.5 & 10.4 & 0.5 \\ 500 & 21.8 & 1.8 & 11.0 & 0.6\end{array}$

Table D22

Return Period, Maximum Water Level, and Water Level Standard Deviation for Profile: Rota 22

\begin{tabular}{rcccc}
$\begin{array}{l}\text { Return Period } \\
\text { yr }\end{array}$ & $\begin{array}{c}\text { Maximum } \\
\text { Level, ft }\end{array}$ Std. Dev., ft & \multicolumn{2}{c}{$\begin{array}{c}\text { Maximum Stil Water Level } \\
\text { Level, ft }\end{array}$} \\
2 & 8.4 & 2.0 & 3.4 & 1.2 \\
5 & 13.3 & 0.8 & 7.3 & 0.6 \\
10 & 15.5 & 0.8 & 8.9 & 0.5 \\
25 & 17.1 & 0.6 & 9.7 & 0.3 \\
50 & 18.1 & 0.9 & 10.1 & 0.3 \\
75 & 18.8 & 1.0 & 10.4 & 0.4 \\
100 & 19.1 & 1.2 & 10.6 & 0.5 \\
500 & 20.4 & 1.5 & 11.1 & 0.6
\end{tabular}

\section{Table D23}

Return Period, Maximum Water Level, and Water Level Standard Deviation for Profile: Rota 23

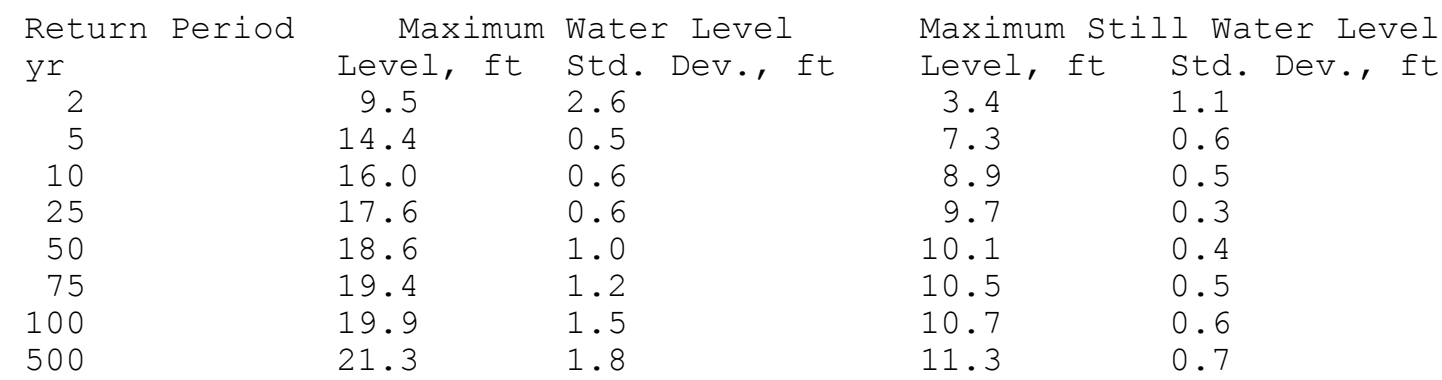

Table D24

Return Period, Maximum Water Level, and Water Level Standard Deviation for Profile: Rota 24

\begin{tabular}{rcccc}
$\begin{array}{l}\text { Return Period } \\
\text { yr }\end{array}$ & $\begin{array}{c}\text { Maximum Water Level } \\
\text { Level, ft }\end{array}$ Std. Dev., ft & \multicolumn{2}{c}{ Maximum Still Water Level } \\
2 & 7.9 & 2.3 & 3.4 & 1.2 \\
5 & 14.0 & 0.5 & 7.2 & 0.6 \\
10 & 14.8 & 0.2 & 8.9 & 0.6 \\
25 & 15.4 & 0.3 & 10.3 & 0.6 \\
50 & 15.9 & 0.5 & 11.3 & 0.9 \\
75 & 16.2 & 0.6 & 12.0 & 1.2 \\
100 & 16.4 & 0.6 & 12.4 & 1.5 \\
500 & 17.1 & 0.8 & 13.8 & 1.8
\end{tabular}


Table D25

Return Period, Maximum Water Level, and Water Level Standard Deviation for Profile: Rota 25

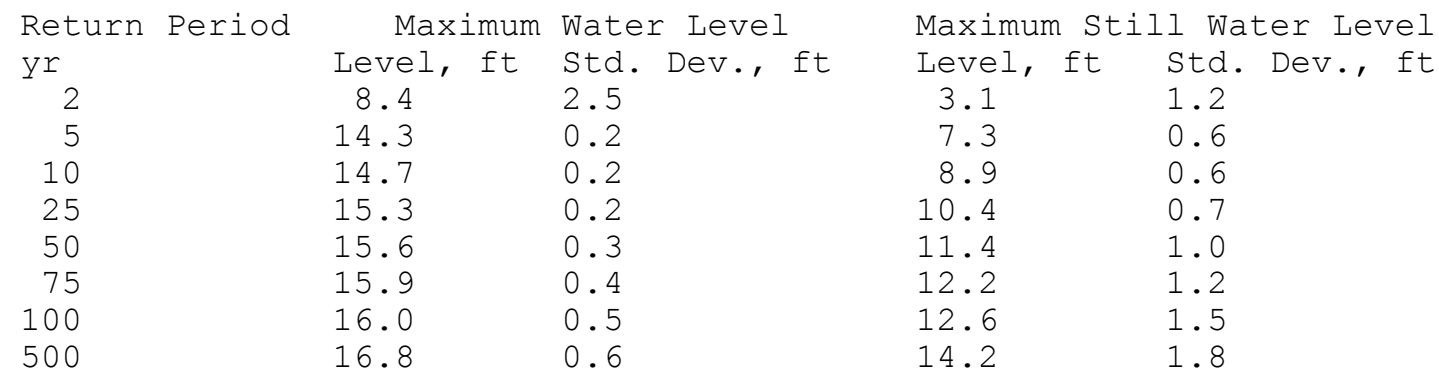

Table D26

Return Period, Maximum Water Level, and Water Level Standard Deviation for Profile: Rota 26

\begin{tabular}{rlrccc} 
Return Period & \multicolumn{2}{c}{ Maximum } & Water Level & Maximum Still Water Level \\
yr & Level, ft & Std. Dev, ft & Level, ft & Std. Dev., ft \\
2 & 10.5 & 3.1 & 3.2 & 1.2 \\
5 & 13.9 & 0.2 & 7.6 & 0.6 \\
10 & 14.5 & 0.2 & 9.1 & 0.5 \\
25 & 15.1 & 0.4 & 10.2 & 0.4 \\
50 & 15.9 & 0.9 & 10.7 & 0.5 \\
75 & 16.6 & 1.3 & 11.1 & 0.6 \\
100 & 17.0 & 1.7 & 11.3 & 0.8 \\
500 & 19.1 & 2.1 & 12.3 & 1.0
\end{tabular}

\section{Table D27}

Return Period, Maximum Water Level, and Water Level Standard Deviation for Profile: Rota 27

\begin{tabular}{rlccc}
$\begin{array}{l}\text { Return Period } \\
\text { yr }\end{array}$ & $\begin{array}{c}\text { Maximum Water Level } \\
\text { Level, ft }\end{array}$ Std. Dev., ft & \multicolumn{2}{c}{ Maximum Stil Water Level, ft } \\
2 & 11.6 & 3.6 & 3.4 & 1.1 \\
5 & 16.9 & 0.3 & 7.3 & 0.5 \\
10 & 17.6 & 0.2 & 8.9 & 0.5 \\
25 & 18.3 & 0.3 & 9.9 & 0.4 \\
50 & 18.8 & 0.6 & 10.4 & 0.4 \\
75 & 19.4 & 1.1 & 10.7 & 0.5 \\
100 & 19.7 & 1.4 & 10.9 & 0.6 \\
500 & 21.4 & 1.8 & 11.6 & 0.7
\end{tabular}

Table D28

Return Period, Maximum Water Level, and Water Level Standard Deviation for Profile: Rota 28

\begin{tabular}{rcccc} 
Return Period & \multicolumn{2}{c}{ Maximum } & Water Level & \multicolumn{2}{c}{ Maximum Still Water Level } \\
yr & Level, ft & Std. Dev., ft & Level, ft Std. Dev., ft \\
2 & 7.8 & 2.6 & 3.4 & 1.2 \\
5 & 14.8 & 0.7 & 7.4 & 0.6 \\
10 & 16.8 & 0.6 & 9.0 & 0.5 \\
25 & 18.0 & 0.5 & 10.1 & 0.4 \\
50 & 18.7 & 0.5 & 10.6 & 0.4 \\
75 & 19.1 & 0.6 & 10.9 & 0.5 \\
100 & 19.3 & 0.8 & 11.0 & 0.6 \\
500 & 20.1 & 0.9 & 11.7 & 0.7
\end{tabular}


Table D29

Return Period, Maximum Water Level, and Water Level standard Deviation for Profile: Rota 29

\begin{tabular}{rlrcr}
$\begin{array}{l}\text { Return Period } \\
\text { yr }\end{array}$ & $\begin{array}{c}\text { Maximum Water Level } \\
\text { Level, ft }\end{array}$ Std. Dev., ft & \multicolumn{2}{c}{ Maximum Stil Water Level } \\
Level, ft & Std. Dev., ft \\
2 & 10.2 & 3.6 & 3.4 & 1.2 \\
5 & 18.4 & 1.1 & 7.4 & 0.5 \\
10 & 22.0 & 0.9 & 9.1 & 0.6 \\
25 & 23.6 & 0.7 & 10.2 & 0.5 \\
50 & 24.5 & 0.9 & 10.8 & 0.6 \\
75 & 25.1 & 1.0 & 11.2 & 0.6 \\
100 & 25.4 & 1.1 & 11.4 & 0.7 \\
500 & 26.9 & 1.3 & 12.4 & 0.9
\end{tabular}

\section{Table D30}

Return Period, Maximum Water Level, and Water Level Standard Deviation for Profile: Rota 30

\begin{tabular}{ccccc}
$\begin{array}{l}\text { Return Period } \\
\text { yr }\end{array}$ & $\begin{array}{c}\text { Maximum } \\
\text { Level, ft }\end{array}$ Std. Dev., ft & \multicolumn{2}{c}{ Maximum Still Water Level } \\
Level, ft & Std. Dev., ft \\
2 & 8.1 & 2.8 & 3.6 & 1.3 \\
5 & 19.1 & 1.8 & 7.8 & 0.6 \\
10 & 23.1 & 0.9 & 9.6 & 0.6 \\
25 & 24.1 & 0.4 & 10.7 & 0.5 \\
50 & 24.6 & 0.4 & 11.4 & 0.6 \\
75 & 24.9 & 0.5 & 11.8 & 0.7 \\
100 & 25.1 & 0.6 & 12.0 & 0.8 \\
500 & 25.9 & 0.7 & 13.1 & 0.9
\end{tabular}

\section{Table D31}

Return Period, Maximum Water Level, and Water Level Standard Deviation for Profile: Rota 31

\begin{tabular}{ccccc}
$\begin{array}{l}\text { Return Period } \\
\text { yr }\end{array}$ & $\begin{array}{c}\text { Maximum } \\
\text { Level, ft }\end{array}$ & Std. Dev Level ft & \multicolumn{2}{c}{$\begin{array}{c}\text { Maximum Stil Water Level } \\
\text { Level, ft }\end{array}$} \\
2 & 9.0 & 3.1 & 3.7 & 1.3 \\
5 & 20.9 & 2.7 & 8.1 & 0.7 \\
10 & 26.0 & 1.3 & 10.0 & 0.6 \\
25 & 27.7 & 0.7 & 11.0 & 0.5 \\
50 & 29.0 & 1.2 & 11.6 & 0.6 \\
75 & 30.0 & 1.7 & 11.9 & 0.6 \\
100 & 30.5 & 2.2 & 12.1 & 0.7 \\
500 & 33.5 & 2.7 & 13.1 & 0.9
\end{tabular}

\section{Table D32}

Return Period, Maximum Water Level, and Water Level Standard Deviation for Profile: Rota 32

\begin{tabular}{lllcc}
$\begin{array}{l}\text { Return Period } \\
\text { yr }\end{array}$ & \multicolumn{2}{c}{ Maximum Water Level } & Maximum Still Water Level \\
2 & Level, ft & Std. Dev., ft & Level, ft & Std. Dev., ft \\
5 & 12.5 & 3.9 & 3.8 & 1.3 \\
10 & 22.1 & 2.3 & 8.4 & 0.7 \\
25 & 27.5 & 1.5 & 10.3 & 0.6 \\
50 & 29.9 & 1.0 & 11.3 & 0.4 \\
75 & 31.2 & 1.2 & 11.8 & 0.4 \\
100 & 32.1 & 1.5 & 12.1 & 0.5 \\
500 & 32.5 & 1.8 & 12.2 & 0.5 \\
& 34.5 & 2.2 & 12.8 & 0.7
\end{tabular}


Table D33

Return Period, Maximum Water Level, and Water Level standard Deviation for Profile: Rota 33

\begin{tabular}{rlccc}
$\begin{array}{l}\text { Return Period } \\
\text { yr }\end{array}$ & $\begin{array}{c}\text { Maximum Water Level } \\
\text { Level, ft }\end{array}$ Std. Dev., ft & \multicolumn{2}{c}{ Maximum Stil Wevel, ft } \\
Lever Level & Std. Dev., ft \\
2 & 13.7 & 4.4 & 3.9 & 1.3 \\
5 & 27.6 & 4.0 & 8.6 & 0.8 \\
10 & 37.8 & 3.2 & 10.6 & 0.6 \\
25 & 44.0 & 2.7 & 11.5 & 0.3 \\
50 & 47.5 & 3.1 & 12.0 & 0.4 \\
75 & 49.4 & 3.2 & 12.3 & 0.5 \\
100 & 50.4 & 3.6 & 12.4 & 0.5 \\
500 & 55.1 & 4.4 & 13.1 & 0.6
\end{tabular}

\section{Table D34}

Return Period, Maximum Water Level, and Water Level Standard Deviation for Profile: Rota 34

\begin{tabular}{|c|c|c|c|c|}
\hline Return Period & Maximum & Water Level & \multicolumn{2}{|c|}{ Maximum Still Water Level } \\
\hline $\mathrm{yr}$ & Level, ft & std. Dev., ft & Level, ft & Std. Dev., ft \\
\hline 2 & 16.9 & 4.4 & 3.9 & 1.3 \\
\hline 5 & 29.5 & 1.9 & 8.7 & 0.8 \\
\hline 10 & 35.5 & 2.3 & 10.7 & 0.6 \\
\hline 25 & 40.3 & 2.1 & 11.6 & 0.4 \\
\hline 50 & 42.9 & 2.5 & 12.1 & 0.4 \\
\hline 75 & 44.4 & 2.5 & 12.4 & 0.5 \\
\hline 100 & 45.2 & 2.9 & 12.5 & 0.5 \\
\hline 500 & 48.9 & 3.5 & 13.2 & 0.7 \\
\hline
\end{tabular}

\section{Table D35}

Return Period, Maximum Water Level, and Water Level Standard Deviation for Profile: Rota 35

$\begin{array}{clccc}\begin{array}{l}\text { Return Period } \\ \text { yr }\end{array} & \begin{array}{c}\text { Maximum Water Level } \\ \text { Level, ft }\end{array} \text { Std. Dev., ft } & \begin{array}{c}\text { Maximum Still Water Level } \\ \text { Level, ft }\end{array} \\ 2 & 10.8 & 3.3 & 4.1 & 1.4 \\ 5 & 23.8 & 2.1 & 9.0 & 0.8 \\ 10 & 27.7 & 1.0 & 11.1 & 0.6 \\ 25 & 29.5 & 0.7 & 12.0 & 0.3 \\ 50 & 30.5 & 1.0 & 12.5 & 0.4 \\ 75 & 31.4 & 1.3 & 12.8 & 0.5 \\ 100 & 31.8 & 1.6 & 12.9 & 0.5 \\ 500 & 34.0 & 2.0 & 13.6 & 0.7\end{array}$

Table D36

Return Period, Maximum Water Level, and Water Level Standard Deviation for Profile: Rota 36

\begin{tabular}{rllcc}
$\begin{array}{l}\text { Return Period } \\
\text { yr }\end{array}$ & $\begin{array}{c}\text { Maximum } \\
\text { Level, ft }\end{array}$ Std. Dev., ft & \multicolumn{2}{c}{ Maximum Still Water Level } \\
Level, ft & Std. Dev., ft \\
2 & 22.6 & 6.3 & 4.1 & 1.4 \\
5 & 38.8 & 3.6 & 9.2 & 0.9 \\
10 & 49.9 & 3.7 & 11.3 & 0.6 \\
25 & 56.8 & 2.9 & 12.4 & 0.4 \\
50 & 60.8 & 3.6 & 13.0 & 0.6 \\
75 & 63.4 & 3.8 & 13.4 & 0.7 \\
100 & 64.8 & 4.4 & 13.7 & 0.8 \\
500 & 70.1 & 5.4 & 14.6 & 1.0
\end{tabular}




\section{Table D37}

Return Period, Maximum Water Level, and Water Level Standard Deviation for Profile: Rota 37

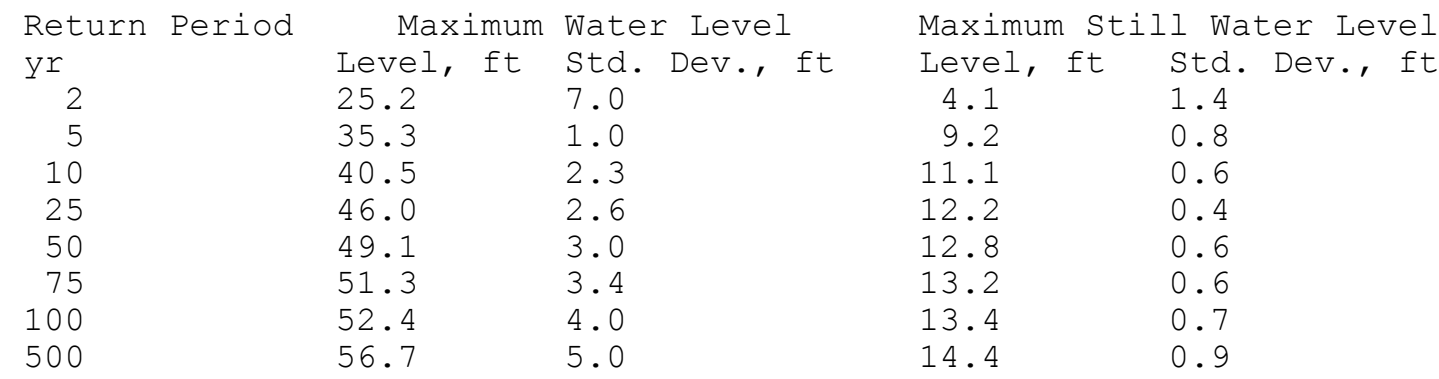

\section{Table D38}

Return Period, Maximum Water Level, and Water Level Standard Deviation for Profile: Rota 38

\begin{tabular}{llccc}
$\begin{array}{l}\text { Return Period } \\
\text { yr }\end{array}$ & $\begin{array}{c}\text { Maximum Water Level } \\
\text { Level, ft }\end{array}$ Std. Dev., ft & \multicolumn{2}{c}{$\begin{array}{c}\text { Maximum Stil Water Level } \\
\text { Level, ft }\end{array}$} \\
2 & 18.2 & 5.0 & 4.1 & Std. Dev., ft \\
5 & 34.7 & 2.6 & 9.2 & 0.8 \\
10 & 43.3 & 2.5 & 11.1 & 0.6 \\
25 & 48.9 & 2.3 & 12.3 & 0.4 \\
50 & 52.3 & 3.0 & 13.0 & 0.6 \\
75 & 54.5 & 3.3 & 13.4 & 0.7 \\
100 & 55.6 & 3.9 & 13.6 & 0.9 \\
500 & 59.7 & 4.9 & 14.6 & 1.1
\end{tabular}

\section{Table D39}

Return Period, Maximum Water Level, and Water Level Standard Deviation for Profile: Rota 39

\begin{tabular}{clccc}
$\begin{array}{l}\text { Return Period } \\
\text { yr }\end{array}$ & $\begin{array}{c}\text { Maximum Water Level } \\
\text { Level, ft }\end{array}$ Std. Dev, ft & \multicolumn{2}{c}{$\begin{array}{c}\text { Maximum Stil Water Level } \\
\text { Level, ft }\end{array}$} \\
2 & 18.9 & 6.4 & 3.9 & 1.4 \\
5 & 38.9 & 3.6 & 8.9 & 0.7 \\
10 & 48.0 & 3.0 & 10.7 & 0.5 \\
25 & 54.6 & 3.1 & 11.7 & 0.4 \\
50 & 58.5 & 3.6 & 12.2 & 0.4 \\
75 & 60.7 & 3.6 & 12.6 & 0.5 \\
100 & 61.8 & 4.0 & 12.8 & 0.6 \\
500 & 67.5 & 4.9 & 13.4 & 0.8
\end{tabular}

Table D40

Return Period, Maximum Water Level, and Water Level Standard Deviation for Profile: Rota 40

\begin{tabular}{|c|c|c|c|c|c|}
\hline Return Period & Maximum & Water Level & Maximum St & 1 Wat & er Level \\
\hline yr & Level, ft & Std. Dev, , ft & Level, ft & Std. & $\operatorname{Dev}$, , ft \\
\hline 2 & 21.5 & 8.4 & 3.7 & 1.4 & \\
\hline 5 & 52.8 & 4.9 & 8.6 & 0.7 & \\
\hline 10 & 61.9 & 2.2 & 10.3 & 0.5 & \\
\hline 25 & 66.9 & 2.2 & 11.4 & 0.4 & \\
\hline 50 & 69.9 & 2.9 & 11.9 & 0.4 & \\
\hline 75 & 71.9 & 3.4 & 12.2 & 0.5 & \\
\hline 100 & 72.9 & 4.0 & 12.4 & 0.6 & \\
\hline 500 & 79.2 & 5.0 & 13.0 & 0.7 & \\
\hline
\end{tabular}


Table D41

Return Period, Maximum Water Level, and Water Level Standard Deviation for Profile: Rota 41

\begin{tabular}{rllcrl} 
Return Period & \multicolumn{2}{c}{ Maximum Water Level } & \multicolumn{2}{c}{ Maximum Still Water Level } \\
yr & Level, ft & Std. Dev., ft & Level, ft & Std. Dev., ft \\
2 & 15.1 & 4.6 & 3.8 & 1.4 \\
5 & 23.8 & 1.0 & 8.7 & 0.7 \\
10 & 26.6 & 0.8 & 10.4 & 0.5 \\
25 & 28.4 & 0.7 & 11.4 & 0.4 \\
50 & 29.4 & 0.9 & 12.0 & 0.4 \\
75 & 30.0 & 0.9 & 12.3 & 0.5 \\
100 & 30.3 & 1.0 & 12.5 & 0.6 \\
500 & 31.7 & 1.3 & 13.2 & 0.7
\end{tabular}

Table D42

Return Period, Maximum Water Level, and Water Level Standard Deviation for Profile: Rota 42

\begin{tabular}{rlccc} 
Return Period & \multicolumn{2}{c}{ Maximum Water Level } & \multicolumn{2}{c}{ Maximum Still Water Level } \\
yr & Level, ft & Std. Dev., ft & Level, ft & Std. Dev., ft \\
2 & 16.1 & 5.2 & 3.8 & 1.4 \\
5 & 26.6 & 1.3 & 8.7 & 0.7 \\
10 & 29.4 & 0.8 & 10.5 & 0.5 \\
25 & 31.0 & 0.7 & 11.5 & 0.4 \\
50 & 31.9 & 0.9 & 12.1 & 0.4 \\
75 & 32.6 & 1.2 & 12.4 & 0.5 \\
100 & 33.0 & 1.5 & 12.6 & 0.6 \\
500 & 35.2 & 1.8 & 13.3 & 0.8
\end{tabular}

\section{Table D43}

Return Period, Maximum Water Level, and Water Level Standard Deviation for Profile: Rota 43

\begin{tabular}{rllcrl} 
Return Period & \multicolumn{2}{c}{ Maximum Water Level } & \multicolumn{2}{c}{ Maximum Still Water Level } \\
yr & Level, ft & Std. Dev., ft & Level, ft & Std. Dev., ft \\
2 & 18.3 & 6.4 & 3.8 & 1.4 & \\
5 & 31.8 & 1.8 & 8.8 & 0.7 \\
10 & 36.9 & 1.6 & 10.5 & 0.6 \\
25 & 41.1 & 2.1 & 11.6 & 0.4 \\
50 & 43.4 & 2.4 & 12.2 & 0.5 \\
75 & 45.4 & 2.6 & 12.5 & 0.6 \\
100 & 46.5 & 3.0 & 12.7 & 0.7 \\
500 & 50.0 & 3.7 & 13.5 & 0.9
\end{tabular}

\section{Table D44}

Return Period, Maximum Water Level, and Water Level Standard Deviation for Profile: Rota 44

\begin{tabular}{rlccc}
$\begin{array}{l}\text { Return Period } \\
\text { yr }\end{array}$ & $\begin{array}{c}\text { Maximum Water Level } \\
\text { Level, ft }\end{array}$ Std. Dev., ft & \multicolumn{2}{c}{ Maximum Still Water Level } \\
2 & 25.8 & 6.7 & 3.8 & 1.4 \\
5 & 36.3 & 2.3 & 8.6 & 0.7 \\
10 & 41.3 & 1.5 & 10.5 & 0.6 \\
25 & 44.9 & 1.9 & 11.6 & 0.4 \\
50 & 47.0 & 2.1 & 12.1 & 0.5 \\
75 & 48.5 & 2.3 & 12.5 & 0.6 \\
100 & 49.3 & 2.6 & 12.7 & 0.7 \\
500 & 52.8 & 3.2 & 13.5 & 0.8
\end{tabular}




\section{Table D45}

Return Period, Maximum Water Level, and Water Level Standard Deviation for Profile: Rota 45

\begin{tabular}{ccccc}
$\begin{array}{l}\text { Return Period } \\
\text { yr }\end{array}$ & \multicolumn{2}{c}{ Maximum Water Level } & \multicolumn{2}{c}{ Maximum Stil Water Level } \\
Level, ft & Std. Dev., ft & Level, ft & Std. Dev., ft \\
2 & 23.7 & 6.0 & 3.8 & 1.4 \\
5 & 35.1 & 1.5 & 8.6 & 0.7 \\
10 & 38.0 & 0.9 & 10.5 & 0.6 \\
25 & 40.2 & 1.1 & 11.7 & 0.5 \\
50 & 41.5 & 1.2 & 12.3 & 0.6 \\
75 & 42.4 & 1.4 & 12.7 & 0.7 \\
100 & 42.8 & 1.5 & 12.9 & 0.8 \\
500 & 44.8 & 1.9 & 13.8 & 0.9
\end{tabular}

\section{Table D46}

Return Period, Maximum Water Level, and Water Level standard Deviation for Profile: Rota 46

\begin{tabular}{rlccc}
$\begin{array}{l}\text { Return Period } \\
\text { yr }\end{array}$ & $\begin{array}{c}\text { Maximum Water Level } \\
\text { Level, ft }\end{array}$ Std. Dev., ft & \multicolumn{2}{c}{ Maximum Still Water Level } \\
Level, ft Std. Dev., ft \\
2 & 10.8 & 4.3 & 3.7 & 1.4 \\
5 & 28.1 & 2.5 & 8.4 & 0.7 \\
10 & 32.7 & 0.9 & 10.3 & 0.6 \\
25 & 34.8 & 0.9 & 11.4 & 0.4 \\
50 & 36.1 & 1.2 & 12.0 & 0.5 \\
75 & 37.0 & 1.5 & 12.4 & 0.8 \\
100 & 37.4 & 1.9 & 12.6 & 0.9 \\
500 & 40.3 & 2.3 & 13.8 & 1.2
\end{tabular}

\section{Table D47}

Return Period, Maximum Water Level, and Water Level standard Deviation for Profile: Rota 47

\begin{tabular}{ccccc}
$\begin{array}{l}\text { Return Period } \\
\text { yr }\end{array}$ & $\begin{array}{c}\text { Maximum } \\
\text { Level, ft }\end{array}$ & Std. Dev Level ft & \multicolumn{2}{c}{ Maximum Still Water Level } \\
Level, ft & Std. Dev., ft \\
2 & 9.2 & 3.1 & 3.9 & 1.5 \\
5 & 20.6 & 1.7 & 8.7 & 0.7 \\
10 & 24.8 & 1.2 & 10.6 & 0.6 \\
25 & 27.0 & 1.0 & 11.9 & 0.5 \\
50 & 28.0 & 1.1 & 12.4 & 0.5 \\
75 & 28.8 & 1.2 & 12.8 & 0.6 \\
100 & 29.1 & 1.4 & 13.0 & 0.7 \\
500 & 31.0 & 1.7 & 13.9 & 0.8
\end{tabular}

\section{Table D48}

Return Period, Maximum Water Level, and Water Level Standard Deviation for Profile: Rota 48

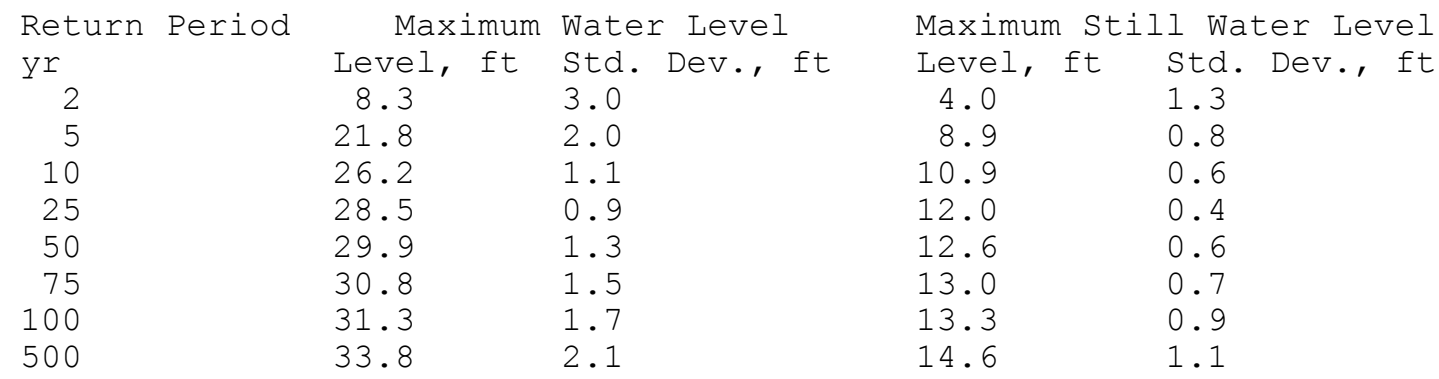


Table D49

Return Period, Maximum Water Level, and Water Level Standard Deviation for Profile: Rota 49

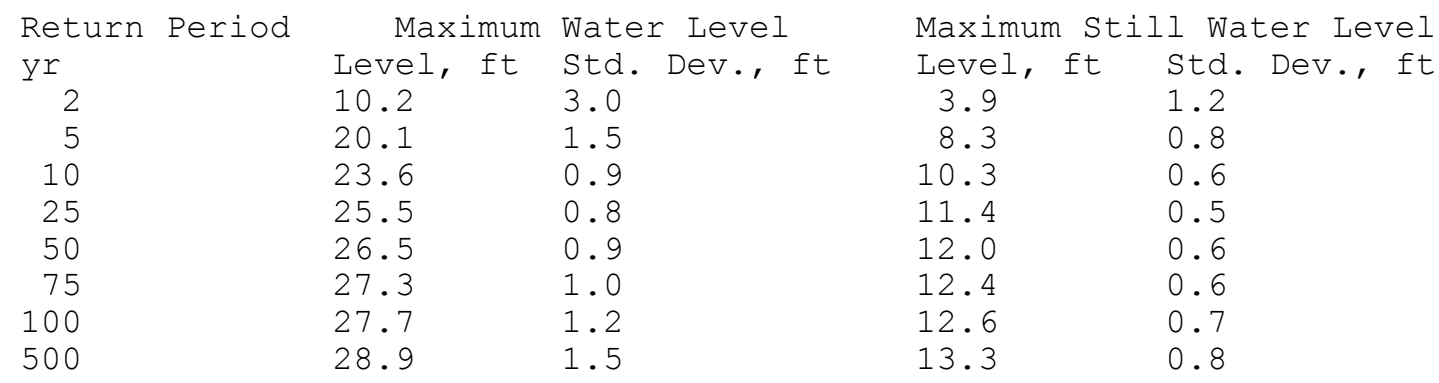

\section{Table D50}

Return Period, Maximum Water Level, and Water Level Standard Deviation for Profile: Rota 50

$\begin{array}{clccc}\begin{array}{l}\text { Return Period } \\ \text { yr }\end{array} & \begin{array}{c}\text { Maximum Water Level } \\ \text { Level, ft }\end{array} \text { Std. Dev, ft } & \begin{array}{c}\text { Maximum Stil Water Level } \\ \text { Level, ft }\end{array} \\ 2 & 12.3 & 3.7 & 4.3 & 1.3 \\ 5 & 21.9 & 0.9 & 9.0 & 0.8 \\ 10 & 24.9 & 1.1 & 11.0 & 0.6 \\ 25 & 27.5 & 1.1 & 12.2 & 0.5 \\ 50 & 28.8 & 1.4 & 12.8 & 0.6 \\ 75 & 29.9 & 1.4 & 13.2 & 0.6 \\ 100 & 30.4 & 1.6 & 13.4 & 0.7 \\ 500 & 32.3 & 2.0 & 14.3 & 0.8\end{array}$

\section{Table D51}

Return Period, Maximum Water Level, and Water Level Standard Deviation for Profile: Rota 51

$\begin{array}{clccc}\begin{array}{l}\text { Return Period } \\ \text { yr }\end{array} & \begin{array}{c}\text { Maximum Water Level } \\ \text { Level, ft }\end{array} \text { Std. Dev, ft } & \begin{array}{c}\text { Maximum Still Water Level } \\ \text { Level, ft }\end{array} \\ 2 & 12.3 & 3.3 & 4.5 & 1.3 \\ 5 & 21.5 & 1.2 & 9.2 & 0.9 \\ 10 & 25.0 & 1.1 & 11.3 & 0.5 \\ 25 & 27.7 & 1.1 & 12.4 & 0.4 \\ 50 & 29.1 & 1.3 & 13.1 & 0.6 \\ 75 & 30.1 & 1.4 & 13.4 & 0.6 \\ 100 & 30.5 & 1.7 & 13.6 & 0.7 \\ 500 & 32.6 & 2.1 & 14.4 & 0.8\end{array}$

\section{Table D52}

Return Period, Maximum Water Level, and Water Level Standard Deviation for Profile: Rota 52

\begin{tabular}{rlccc}
$\begin{array}{l}\text { Return Period } \\
\text { yr }\end{array}$ & $\begin{array}{c}\text { Maximum Water Level } \\
\text { Level, ft }\end{array}$ Std. Dev., ft & \multicolumn{2}{c}{ Maximum Still Water Level } \\
2 & 11.7 & 3.1 & 4.6 & 1.4 \\
5 & 22.3 & 1.9 & 9.4 & 1.0 \\
10 & 25.9 & 1.0 & 11.4 & 0.6 \\
25 & 28.0 & 0.6 & 12.5 & 0.3 \\
50 & 29.0 & 0.9 & 13.0 & 0.5 \\
75 & 29.8 & 1.1 & 13.4 & 0.6 \\
100 & 30.2 & 1.4 & 13.7 & 0.8 \\
500 & 31.7 & 1.7 & 14.6 & 0.9
\end{tabular}




\section{Table D53}

Return Period, Maximum Water Level, and Water Level Standard Deviation for Profile: Rota 53

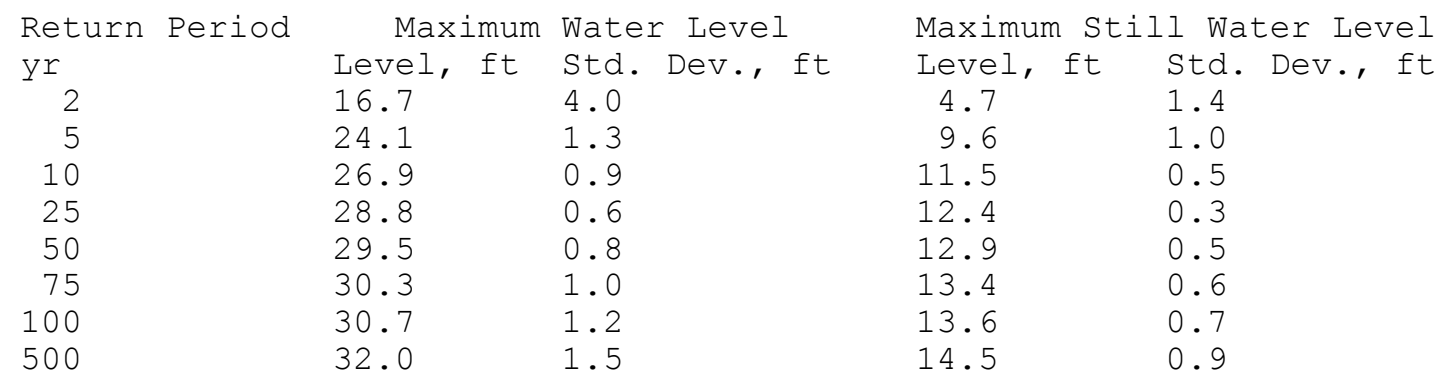

\section{Table D54}

Return Period, Maximum Water Level, and Water Level Standard Deviation for Profile: Rota 54

\begin{tabular}{|c|c|c|c|c|}
\hline Return Period & Maximum & Water Level & Maximum $\mathrm{S}$ & Ll Water Level \\
\hline $\mathrm{yr}$ & Level, ft & std. Dev, ft & Level, ft & Std. Dev, , ft \\
\hline 2 & 15.5 & 3.8 & 4.6 & 1.3 \\
\hline 5 & 24.0 & 0.9 & 9.3 & 0.9 \\
\hline 10 & 26.3 & 0.6 & 11.1 & 0.5 \\
\hline 25 & 27.8 & 0.5 & 12.0 & 0.3 \\
\hline 50 & 28.6 & 0.8 & 12.5 & 0.5 \\
\hline 75 & 29.2 & 1.0 & 12.9 & 0.6 \\
\hline 100 & 29.6 & 1.2 & 13.2 & 0.7 \\
\hline 500 & 31.2 & 1.5 & 14.0 & 0.9 \\
\hline
\end{tabular}

\section{Table D55}

Return Period, Maximum Water Level, and Water Level Standard Deviation for Profile: Rota 55

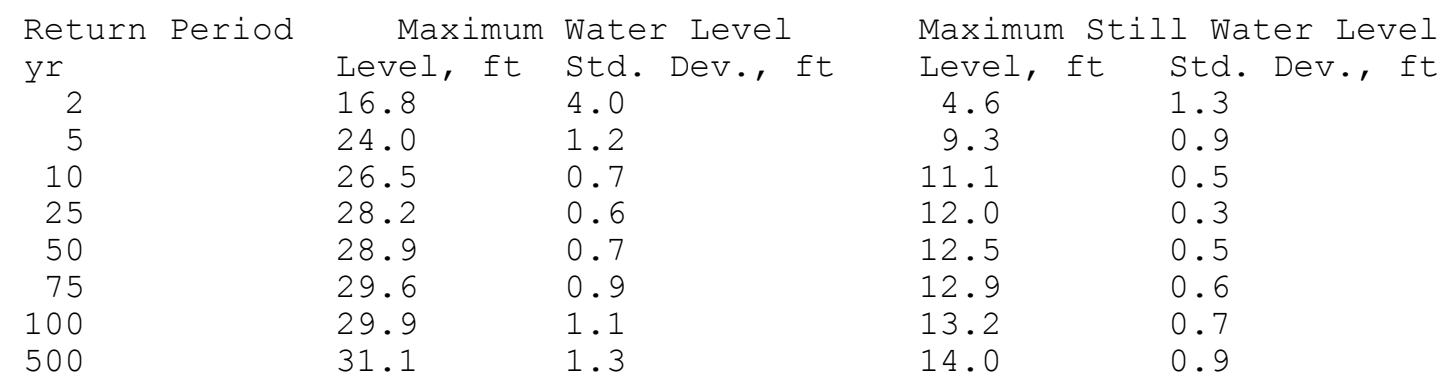

\section{Table D56}

Return Period, Maximum Water Level, and Water Level Standard Deviation for Profile: Rota 56

\begin{tabular}{rlrcr}
$\begin{array}{l}\text { Return Period } \\
\text { yr }\end{array}$ & $\begin{array}{c}\text { Maximum Water Level } \\
\text { Level, ft }\end{array}$ Std. Dev., ft & \multicolumn{2}{c}{ Maximum Still Water Level } \\
2 & 15.6 & 3.7 & 4.7 & Std. Dev., ft \\
5 & 22.9 & 2.0 & 9.4 & 0.9 \\
10 & 26.4 & 1.0 & 11.3 & 0.5 \\
25 & 28.3 & 0.6 & 12.2 & 0.3 \\
50 & 29.1 & 0.8 & 12.8 & 0.5 \\
75 & 29.9 & 1.0 & 13.2 & 0.6 \\
100 & 30.2 & 1.2 & 13.4 & 0.7 \\
500 & 31.5 & 1.5 & 14.2 & 0.9
\end{tabular}


Table D57

Return Period, Maximum Water Level, and Water Level Standard Deviation for Profile: Rota 57

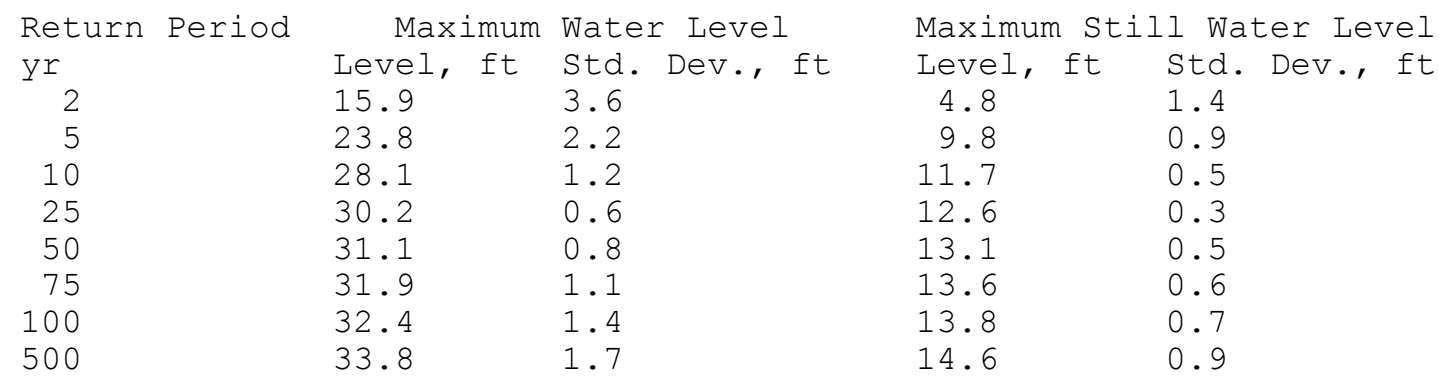

\section{Table D58}

Return Period, Maximum Water Level, and Water Level Standard Deviation for Profile: Rota 58

\begin{tabular}{llccc}
$\begin{array}{l}\text { Return Period } \\
\text { yr }\end{array}$ & $\begin{array}{c}\text { Maximum Water Level } \\
\text { Level, ft }\end{array}$ Std. Dev, ft & \multicolumn{2}{c}{$\begin{array}{c}\text { Maximum Stil Water Level } \\
\text { Level, ft }\end{array}$} \\
2 & 11.5 & 3.0 & 5.0 & 1.5 \\
5 & 22.9 & 1.8 & 10.2 & 0.9 \\
10 & 26.3 & 0.9 & 12.2 & 0.5 \\
25 & 28.0 & 0.6 & 13.1 & 0.4 \\
50 & 28.7 & 0.8 & 13.6 & 0.5 \\
75 & 29.5 & 0.9 & 14.0 & 0.6 \\
100 & 29.9 & 1.2 & 14.2 & 0.7 \\
500 & 31.2 & 1.5 & 15.1 & 0.9
\end{tabular}

\section{Table D59}

Return Period, Maximum Water Level, and Water Level Standard Deviation for Profile: Rota 59

$\begin{array}{clccc}\begin{array}{l}\text { Return Period } \\ \text { yr }\end{array} & \begin{array}{c}\text { Maximum Water Level } \\ \text { Level, ft }\end{array} \text { Std. Dev, ft } & \begin{array}{c}\text { Maximum Still Water Level } \\ \text { Level, ft }\end{array} \\ 2 & 14.4 & 3.4 & 4.8 & 1.4 \\ 5 & 24.5 & 2.0 & 9.8 & 0.9 \\ 10 & 28.1 & 1.1 & 11.7 & 0.6 \\ 25 & 30.0 & 0.6 & 12.6 & 0.3 \\ 50 & 30.8 & 0.9 & 13.1 & 0.5 \\ 75 & 31.5 & 1.0 & 13.6 & 0.6 \\ 100 & 31.9 & 1.2 & 13.8 & 0.7 \\ 500 & 33.3 & 1.5 & 14.6 & 0.8\end{array}$

\section{Table D60}

Return Period, Maximum Water Level, and Water Level Standard Deviation for Profile: Rota 60

\begin{tabular}{rlccc}
$\begin{array}{l}\text { Return Period } \\
\text { yr }\end{array}$ & $\begin{array}{c}\text { Maximum Water Level } \\
\text { Level, ft }\end{array}$ Std. Dev., ft & \multicolumn{2}{c}{ Maximum Stil Water Level } \\
2 & 21.6 & 4.9 & 4.4 & 1.3 \\
5 & 31.2 & 1.7 & 9.0 & 0.9 \\
10 & 34.6 & 0.8 & 10.9 & 0.5 \\
25 & 36.2 & 0.5 & 11.7 & 0.4 \\
50 & 36.9 & 0.8 & 12.3 & 0.6 \\
75 & 37.6 & 0.9 & 12.7 & 0.7 \\
100 & 38.0 & 1.1 & 13.0 & 0.8 \\
500 & 39.4 & 1.4 & 14.1 & 1.0
\end{tabular}




\section{Table D61}

Return Period, Maximum Water Level, and Water Level Standard Deviation for Profile: Rota 61

\begin{tabular}{clccc}
$\begin{array}{l}\text { Return Period } \\
\text { yr }\end{array}$ & \multicolumn{2}{c}{ Maximum Water Level } & Maximum Still Water Level \\
2 & Level, ft & Std. Dev., ft & Level, ft & Std. Dev., ft \\
2 & 13.5 & 3.4 & 4.4 & 1.3 \\
5 & 21.2 & 1.7 & 9.0 & 0.9 \\
10 & 24.4 & 0.8 & 10.8 & 0.4 \\
25 & 25.9 & 0.5 & 11.6 & 0.3 \\
50 & 26.5 & 0.7 & 12.0 & 0.4 \\
75 & 27.2 & 0.9 & 12.3 & 0.4 \\
100 & 27.5 & 1.0 & 12.5 & 0.5 \\
500 & 28.7 & 1.3 & 13.1 & 0.7
\end{tabular}

\section{Table D62}

Return Period, Maximum Water Level, and Water Level standard Deviation for Profile: Rota 62

\begin{tabular}{|c|c|c|c|c|}
\hline Return Period & Maximum & Water Level & Maximum $\mathrm{S}$ & Ll Water Level \\
\hline $\mathrm{yr}$ & Level, ft & std. Dev, ft & Level, ft & Std. Dev, , ft \\
\hline 2 & 14.3 & 3.3 & 4.4 & 1.4 \\
\hline 5 & 21.1 & 2.2 & 9.0 & 0.9 \\
\hline 10 & 25.0 & 1.0 & 10.9 & 0.5 \\
\hline 25 & 26.3 & 0.4 & 11.8 & 0.3 \\
\hline 50 & 26.9 & 0.6 & 12.2 & 0.4 \\
\hline 75 & 27.5 & 0.8 & 12.6 & 0.5 \\
\hline 100 & 27.8 & 1.0 & 12.7 & 0.6 \\
\hline 500 & 28.9 & 1.3 & 13.4 & 0.7 \\
\hline
\end{tabular}

\section{Table D63}

Return Period, Maximum Water Level, and Water Level Standard Deviation for Profile: Rota 63

$\begin{array}{llccc}\begin{array}{l}\text { Return Period } \\ \text { yr }\end{array} & \begin{array}{c}\text { Maximum Water Level } \\ \text { Level, ft }\end{array} \text { Std. Dev, ft } & \begin{array}{c}\text { Maximum Stil Water Level } \\ \text { Level, ft }\end{array} \\ 2 & 12.5 & 4.2 & 4.2 & 1.3 \\ 5 & 20.8 & 1.4 & 9.2 & 0.8 \\ 10 & 23.5 & 0.6 & 10.8 & 0.4 \\ 25 & 24.8 & 0.5 & 11.6 & 0.3 \\ 50 & 25.5 & 0.6 & 12.0 & 0.4 \\ 75 & 26.1 & 0.8 & 12.4 & 0.4 \\ 100 & 26.4 & 1.0 & 12.5 & 0.5 \\ 500 & 27.5 & 1.3 & 13.2 & 0.7\end{array}$

\section{Table D64}

Return Period, Maximum Water Level, and Water Level Standard Deviation for Profile: Rota 64

\begin{tabular}{|c|c|c|c|c|c|}
\hline Return Period & Maximum & Water Level & Maximum $\mathrm{S}$ & $1 \mathrm{Wa}$ & er Leve] \\
\hline yr & Level, ft & Std. Dev., ft & Level, ft & Std. & $\operatorname{Dev}$, ft \\
\hline 2 & 10.6 & 3.0 & 4.4 & 1.4 & \\
\hline 5 & 19.4 & 2.1 & 9.2 & 0.9 & \\
\hline 10 & 22.8 & 0.9 & 11.1 & 0.5 & \\
\hline 25 & 24.3 & 0.6 & 12.0 & 0.3 & \\
\hline 50 & 25.3 & 0.7 & 12.4 & 0.4 & \\
\hline 75 & 26.0 & 0.9 & 12.8 & 0.5 & \\
\hline 100 & 26.3 & 1.1 & 13.0 & 0.6 & \\
\hline 500 & 27.4 & 1.4 & 13.6 & 0.7 & \\
\hline
\end{tabular}


Table D65

Return Period, Maximum Water Level, and Water Level Standard Deviation for Profile: Rota 65

\begin{tabular}{rccccc} 
Return Period & \multicolumn{2}{c}{ Maximum Water Level } & \multicolumn{2}{c}{ Maximum Still Water Level } \\
yr & Level, ft & Std. Dev., ft & Level, ft & Std. Dev., ft \\
2 & 8.9 & 3.0 & 4.5 & 1.4 & \\
5 & 18.6 & 1.4 & 9.2 & 0.9 \\
10 & 21.2 & 0.7 & 11.1 & 0.5 \\
25 & 22.7 & 0.6 & 12.0 & 0.3 \\
50 & 23.7 & 0.9 & 12.4 & 0.4 \\
75 & 24.4 & 1.2 & 12.7 & 0.5 \\
100 & 24.8 & 1.5 & & 12.9 & 0.6 \\
500 & 26.6 & 1.9 & 13.6 & 0.7
\end{tabular}

\section{Table D66}

Return Period, Maximum Water Level, and Water Level Standard Deviation for Profile: Rota 66

\begin{tabular}{llccc}
$\begin{array}{l}\text { Return Period } \\
\text { yr }\end{array}$ & $\begin{array}{c}\text { Maximum } \\
\text { Level, ft }\end{array}$ Std. Dev., ft & \multicolumn{2}{c}{ Maximum Still Water Level } \\
Level, ft Std. Dev., ft \\
2 & 11.4 & 3.2 & 4.3 & 1.3 \\
5 & 17.9 & 1.5 & 8.7 & 0.9 \\
10 & 20.7 & 0.8 & 10.5 & 0.5 \\
25 & 22.1 & 0.5 & 11.3 & 0.3 \\
50 & 22.7 & 0.6 & 11.7 & 0.4 \\
75 & 23.3 & 0.8 & 12.0 & 0.4 \\
100 & 23.6 & 1.0 & 12.2 & 0.5 \\
500 & 24.6 & 1.2 & 12.8 & 0.7
\end{tabular}

\section{Table D67}

Return Period, Maximum Water Level, and Water Level Standard Deviation for Profile: Rota 67

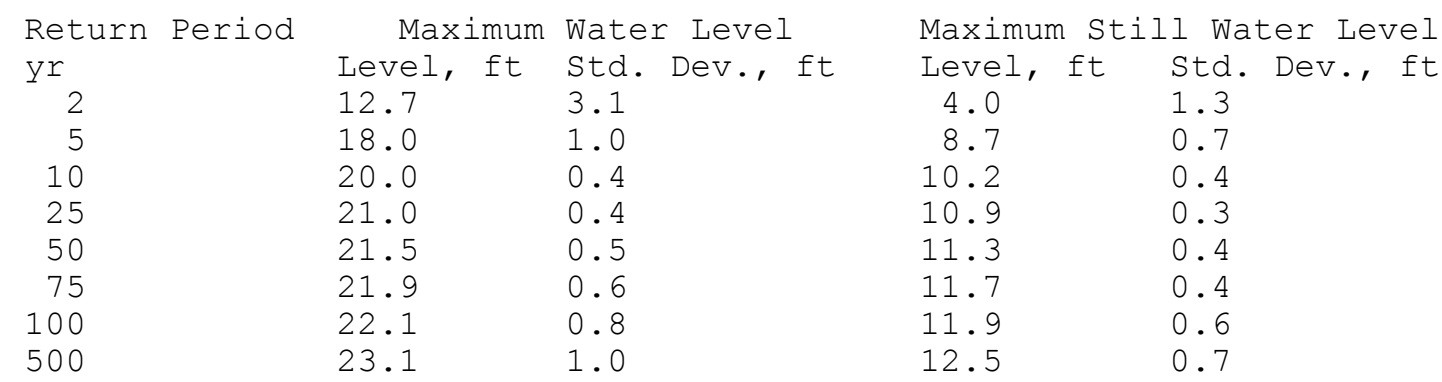

Table D68

Return Period, Maximum Water Level, and Water Level Standard Deviation for Profile: Rota 68

\begin{tabular}{rlrcc} 
Return Period & \multicolumn{2}{c}{ Maximum } & Water Level & Maximum Still Water Level \\
yr & Level, ft & Std. Dev, ft & Level, ft & Std. Dev., ft \\
2 & 11.6 & 2.9 & 4.2 & 1.3 \\
5 & 18.2 & 1.4 & 8.5 & 0.9 \\
10 & 20.7 & 0.6 & 10.3 & 0.5 \\
25 & 21.8 & 0.4 & 11.1 & 0.3 \\
50 & 22.4 & 0.6 & 11.5 & 0.4 \\
75 & 22.9 & 0.7 & 11.9 & 0.5 \\
100 & 23.1 & 0.9 & 12.0 & 0.5 \\
500 & 24.2 & 1.1 & 12.7 & 0.7
\end{tabular}




\section{Table D69}

Return Period, Maximum Water Level, and Water Level standard Deviation for Profile: Rota 69

\begin{tabular}{rlccc}
$\begin{array}{l}\text { Return Period } \\
\text { yr }\end{array}$ & \multicolumn{2}{c}{ Maximum Water Level } & Maximum Stil Water Level \\
Level, ft & Std. Dev., ft & Level, ft & Std. Dev., ft \\
2 & 11.2 & 3.2 & 4.2 & 1.3 \\
5 & 19.1 & 1.8 & 8.4 & 0.9 \\
10 & 22.1 & 0.7 & 10.3 & 0.5 \\
25 & 23.6 & 0.6 & 11.2 & 0.3 \\
50 & 24.4 & 0.8 & 11.6 & 0.4 \\
75 & 25.1 & 1.0 & 11.9 & 0.5 \\
100 & 25.4 & 1.2 & 12.0 & 0.5 \\
500 & 27.1 & 1.5 & 12.7 & 0.7
\end{tabular}

\section{Table D70}

Return Period, Maximum Water Level, and Water Level Standard Deviation for Profile: Rota 70

\begin{tabular}{|c|c|c|c|c|}
\hline Return Period & Maximum & Water Level & Maximum $\mathrm{S}$ & Ll Water Level \\
\hline yr & Level, ft & Std. Dev, , ft & Level, ft & Std. Dev, ft \\
\hline 2 & 10.8 & 3.0 & 4.4 & 1.3 \\
\hline 5 & 19.2 & 1.9 & 8.9 & 1.0 \\
\hline 10 & 22.3 & 0.8 & 10.9 & 0.6 \\
\hline 25 & 23.3 & 0.4 & 11.8 & 0.3 \\
\hline 50 & 23.9 & 0.6 & 12.3 & 0.4 \\
\hline 75 & 24.5 & 0.9 & 12.6 & 0.5 \\
\hline 100 & 24.8 & 1.1 & 12.8 & 0.6 \\
\hline 500 & 26.2 & 1.3 & 13.6 & 0.8 \\
\hline
\end{tabular}

\section{Table D71}

Return Period, Maximum Water Level, and Water Level Standard Deviation for Profile: Rota 71

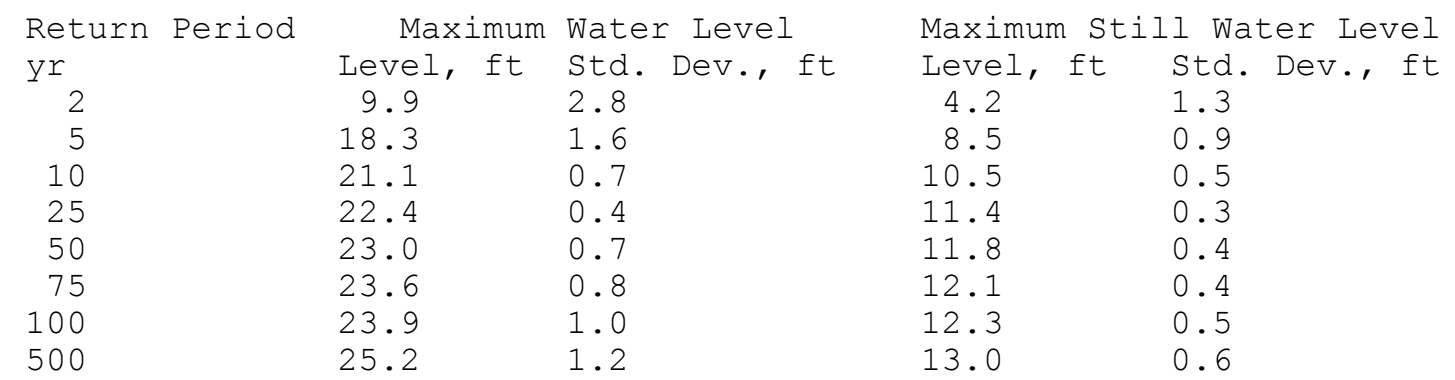

Table D72

Return Period, Maximum Water Level, and Water Level Standard Deviation for Profile: Rota 72

\begin{tabular}{|c|c|c|c|c|c|}
\hline Return Period & Maximum & Water Level & Maximum $\mathrm{S}$ & 11 Wat & er Level \\
\hline yr & Level, ft & Std. Dev., ft & Level, ft & std. & $\operatorname{Dev}$, , ft \\
\hline 2 & 9.4 & 2.4 & 4.0 & 1.2 & \\
\hline 5 & 15.2 & 1.1 & 8.1 & 0.9 & \\
\hline 10 & 17.2 & 0.5 & 9.8 & 0.5 & \\
\hline 25 & 18.2 & 0.3 & 10.7 & 0.3 & \\
\hline 50 & 18.6 & 0.4 & 11.1 & 0.4 & \\
\hline 75 & 19.0 & 0.5 & 11.5 & 0.4 & \\
\hline 100 & 19.2 & 0.6 & 11.7 & 0.5 & \\
\hline 500 & 19.9 & 0.8 & 12.3 & 0.6 & \\
\hline
\end{tabular}


Table D73

Return Period, Maximum Water Level, and Water Level Standard Deviation for Profile: Rota 73

\begin{tabular}{rcccc} 
Return Period & \multicolumn{2}{c}{ Maximum Water Level } & \multicolumn{2}{c}{ Maximum Still Water Level } \\
yr & Level, ft & Std. Dev., ft & Level, ft Std. Dev., ft \\
2 & 9.7 & 2.4 & 4.1 & 1.3 \\
5 & 13.0 & 0.2 & 8.3 & 0.9 \\
10 & 13.6 & 0.3 & 10.2 & 0.5 \\
25 & 14.3 & 0.3 & 11.1 & 0.4 \\
50 & 14.8 & 0.4 & 11.6 & 0.4 \\
75 & 15.2 & 0.5 & 11.9 & 0.5 \\
100 & 15.4 & 0.6 & 12.1 & 0.6 \\
500 & 16.0 & 0.8 & 12.8 & 0.7
\end{tabular}

\section{Table D74}

Return Period, Maximum Water Level, and Water Level Standard Deviation for Profile: Rota 74

$\begin{array}{ccccc}\begin{array}{c}\text { Return Period } \\ \text { yr }\end{array} & \begin{array}{c}\text { Maximum Water Level } \\ \text { Level, ft }\end{array} & \begin{array}{c}\text { Maximum Stil Water Level } \\ \text { Level, ft }\end{array} \\ 2 & 9.0 & 2.1 & 4.1 & \text { Std. Dev., ft } \\ 5 & 13.3 & 0.7 & 8.1 & 0.8 \\ 10 & 14.6 & 0.3 & 10.0 & 0.5 \\ 25 & 15.1 & 0.3 & 10.9 & 0.4 \\ 50 & 15.4 & 0.2 & 11.5 & 0.5 \\ 75 & 15.6 & 0.2 & 11.8 & 0.6 \\ 100 & 15.6 & 0.3 & 12.0 & 0.6 \\ 500 & 16.0 & 0.3 & 12.8 & 0.8\end{array}$

\section{Table D75}

Return Period, Maximum Water Level, and Water Level Standard Deviation for Profile: Rota 75

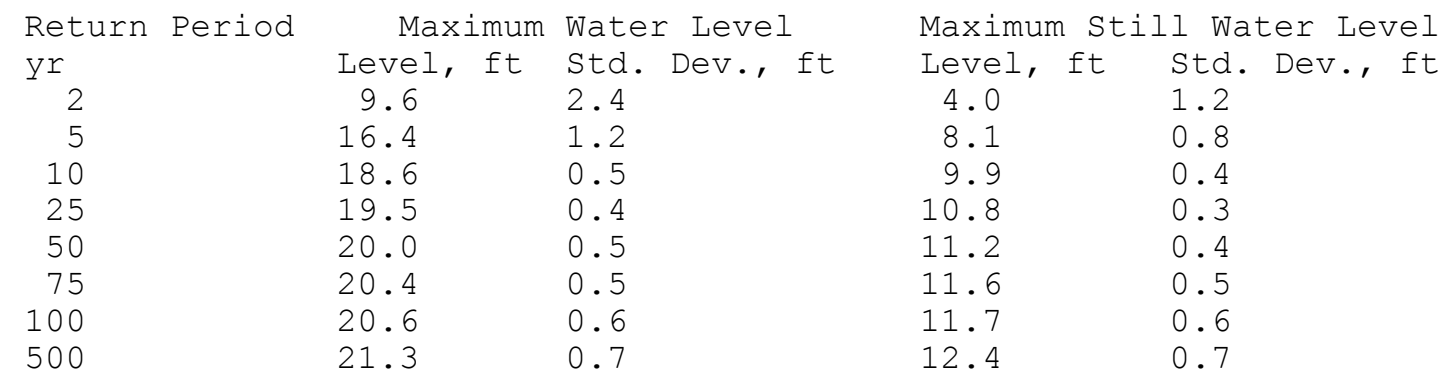

Table D76

Return Period, Maximum Water Level, and Water Level Standard Deviation for Profile: Rota 76

\begin{tabular}{rlrcr}
$\begin{array}{l}\text { Return Period } \\
\text { yr }\end{array}$ & $\begin{array}{c}\text { Maximum Water Level } \\
\text { Level, ft }\end{array}$ Std. Dev., ft & \multicolumn{2}{c}{ Maximum Still Water Level } \\
2 & 12.4 & 3.2 & 4.0 & 1.3 \\
5 & 17.5 & 0.4 & 8.5 & 0.8 \\
10 & 18.7 & 0.4 & 10.1 & 0.4 \\
25 & 19.7 & 0.4 & 11.0 & 0.3 \\
50 & 20.3 & 0.5 & 11.5 & 0.5 \\
75 & 20.8 & 0.6 & 11.9 & 0.6 \\
100 & 21.0 & 0.8 & 12.1 & 0.7 \\
500 & 21.9 & 1.0 & 12.9 & 0.8
\end{tabular}




\section{Table D77}

Return Period, Maximum Water Level, and Water Level Standard Deviation for Profile: Rota 77

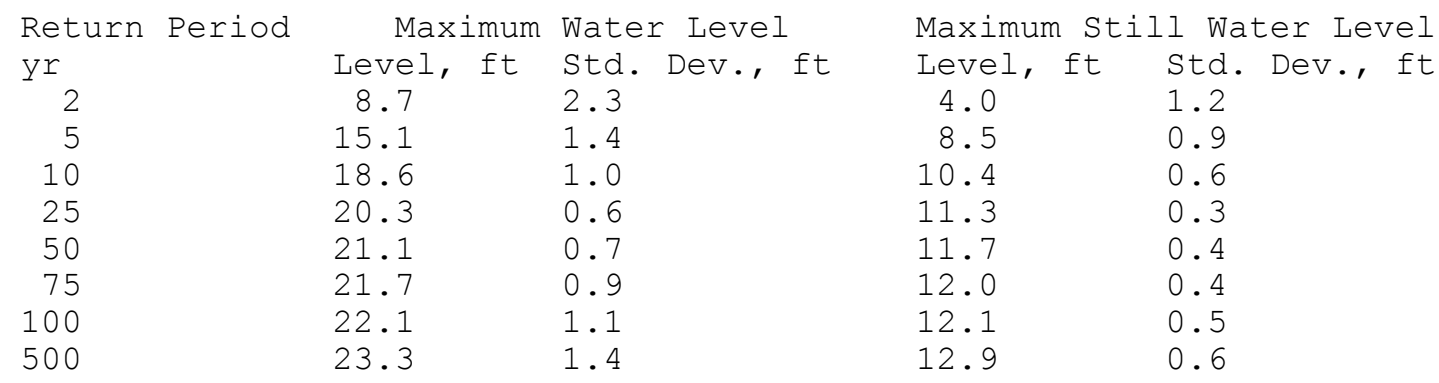

\section{Table D78}

Return Period, Maximum Water Level, and Water Level Standard Deviation for Profile: Rota 78

\begin{tabular}{|c|c|c|c|c|}
\hline Return Period & Maximum & Water Level & Maximum $\mathrm{S}$ & Ll Water Level \\
\hline $\mathrm{yr}$ & Level, ft & std. Dev, ft & Level, ft & Std. Dev, , ft \\
\hline 2 & 11.5 & 2.9 & 4.1 & 1.3 \\
\hline 5 & 18.4 & 1.7 & 8.8 & 0.9 \\
\hline 10 & 22.4 & 1.1 & 10.7 & 0.6 \\
\hline 25 & 24.1 & 0.5 & 11.6 & 0.3 \\
\hline 50 & 24.8 & 0.6 & 12.0 & 0.4 \\
\hline 75 & 25.4 & 0.8 & 12.3 & 0.4 \\
\hline 100 & 25.7 & 1.0 & 12.5 & 0.5 \\
\hline 500 & 26.9 & 1.2 & 13.2 & 0.6 \\
\hline
\end{tabular}

\section{Table D79}

Return Period, Maximum Water Level, and Water Level Standard Deviation for Profile: Rota 79

\begin{tabular}{|c|c|c|c|c|}
\hline Return Period & Maximum & Water Level & \multicolumn{2}{|c|}{ Maximum Still Water Level } \\
\hline yr & Level, ft & std. Dev., ft & Level, ft & Std. Dev., ft \\
\hline 2 & 12.1 & 3.0 & 4.1 & 1.3 \\
\hline 5 & 18.9 & 1.7 & 8.8 & 0.9 \\
\hline 10 & 22.9 & 1.1 & 10.7 & 0.6 \\
\hline 25 & 24.5 & 0.5 & 11.5 & 0.3 \\
\hline 50 & 25.2 & 0.6 & 12.0 & 0.4 \\
\hline 75 & 25.8 & 0.8 & 12.3 & 0.4 \\
\hline 100 & 26.1 & 1.0 & 12.4 & 0.5 \\
\hline 500 & 27.4 & 1.2 & 13.1 & 0.6 \\
\hline
\end{tabular}

\section{Table D80}

Return Period, Maximum Water Level, and Water Level Standard Deviation for Profile: Rota 80

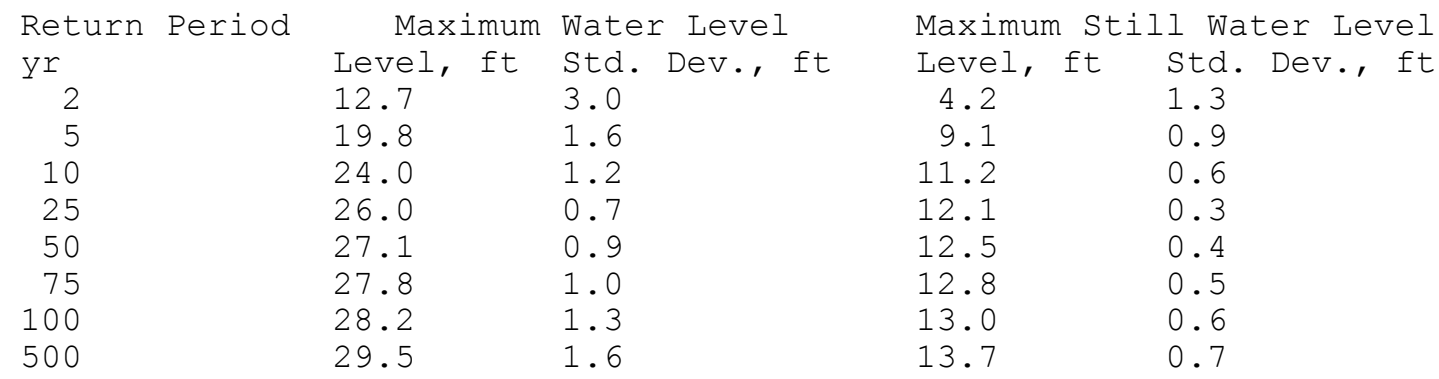


Table D81

Return Period, Maximum Water Level, and Water Level Standard Deviation for Profile: Rota 81

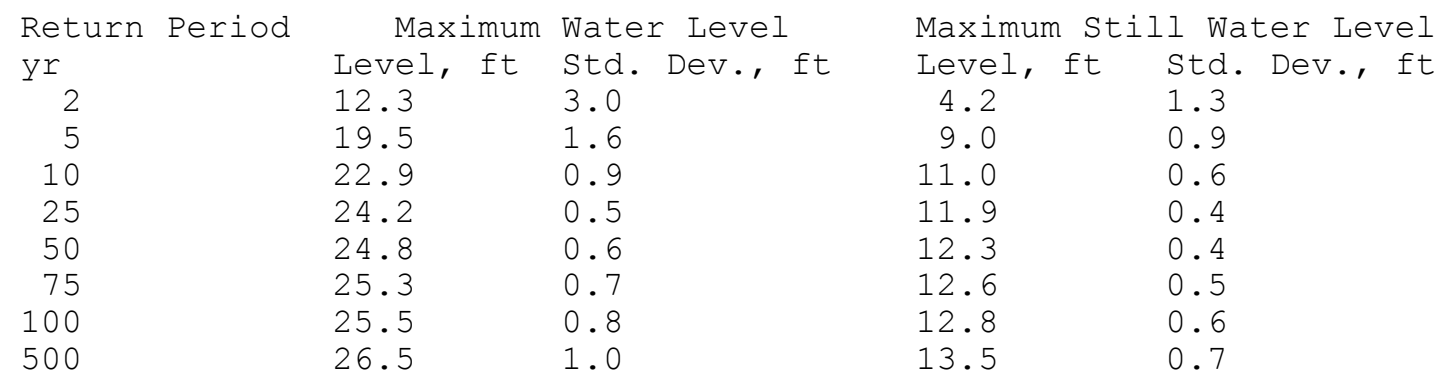

Table D82

Return Period, Maximum Water Level, and Water Level Standard Deviation for Profile: Rota 82

\begin{tabular}{rlccc} 
Return Period & \multicolumn{2}{c}{ Maximum Water Level } & \multicolumn{2}{c}{ Maximum Still Water Level } \\
yr & Level, ft & Std. Dev., ft & Level, ft & Std. Dev., ft \\
2 & 14.0 & 3.7 & 4.1 & 1.3 \\
5 & 20.5 & 1.9 & 8.9 & 0.9 \\
10 & 24.8 & 1.2 & 10.9 & 0.6 \\
25 & 26.4 & 0.6 & 11.8 & 0.3 \\
50 & 27.2 & 0.8 & 12.2 & 0.4 \\
75 & 27.8 & 0.9 & 12.6 & 0.5 \\
100 & 28.1 & 1.0 & 12.7 & 0.5 \\
500 & 29.4 & 1.3 & 13.4 & 0.7
\end{tabular}

\section{Table D83}

Return Period, Maximum Water Level, and Water Level Standard Deviation for Profile: Rota 83

\begin{tabular}{rllcrl} 
Return Period & \multicolumn{2}{c}{ Maximum Water Level } & \multicolumn{2}{c}{ Maximum Still Water Level } \\
yr & Level, ft & Std. Dev., ft & Level, ft & Std. Dev., ft \\
2 & 14.6 & 4.0 & 4.1 & 1.3 \\
5 & 22.2 & 1.5 & 8.9 & 0.8 \\
10 & 25.8 & 1.0 & 11.0 & 0.6 \\
25 & 27.8 & 0.9 & 12.0 & 0.3 \\
50 & 29.0 & 1.0 & 12.5 & 0.5 \\
75 & 29.8 & 1.2 & 12.9 & 0.6 \\
100 & 30.2 & 1.5 & 13.0 & 0.6 \\
500 & 32.0 & 1.8 & & 13.9 & 0.8
\end{tabular}

Table D84

Return Period, Maximum Water Level, and Water Level Standard Deviation for Profile: Rota 84

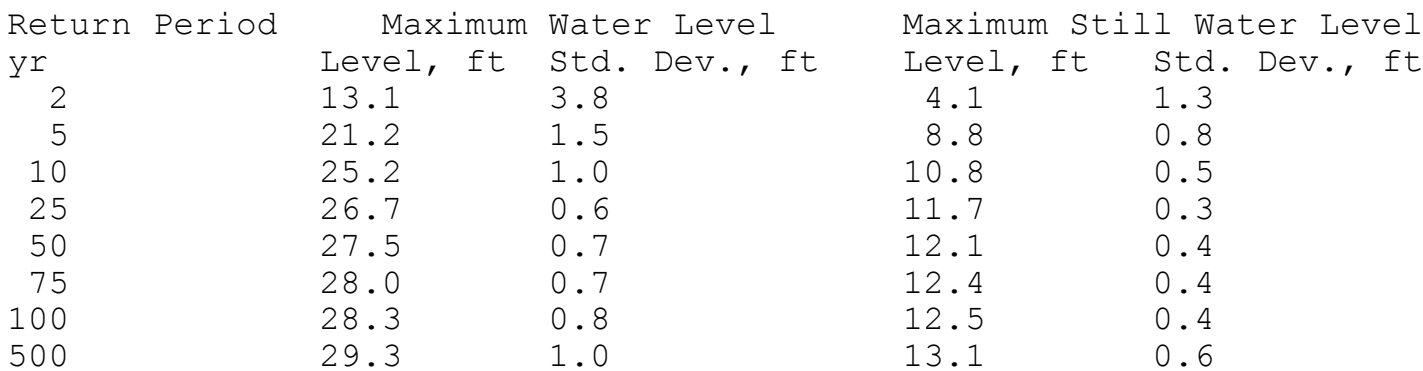




\section{Table D85}

Return Period, Maximum Water Level, and Water Level Standard Deviation for Profile: Rota 85

$\begin{array}{llccc}\begin{array}{l}\text { Return Period } \\ \text { yr }\end{array} & \begin{array}{c}\text { Maximum } \\ \text { Level, ft }\end{array} & \text { Std. Dev., ft } & \text { Maximum Still Water Level } \\ \text { Level, ft } & \text { Std. Dev., ft } \\ 2 & 14.1 & 4.2 & 4.0 & 1.3 \\ 5 & 29.7 & 2.1 & 8.8 & 0.8 \\ 10 & 34.0 & 1.1 & 10.8 & 0.5 \\ 25 & 35.8 & 0.7 & 11.6 & 0.3 \\ 50 & 36.9 & 0.9 & 12.0 & 0.3 \\ 75 & 37.8 & 1.5 & 12.2 & 0.4 \\ 100 & 38.3 & 2.0 & 12.4 & 0.5 \\ 500 & 40.2 & 2.5 & 12.9 & 0.6\end{array}$

\section{Table D86}

Return Period, Maximum Water Level, and Water Level Standard Deviation for Profile: Rota 86

$\begin{array}{llccc}\begin{array}{l}\text { Return Period } \\ \text { yr }\end{array} & \begin{array}{c}\text { Maximum Water Level } \\ \text { Level, ft }\end{array} \text { Std. Dev, ft } & \begin{array}{c}\text { Maximum Still Water Level } \\ \text { Level, ft }\end{array} \\ 2 & 14.1 & 3.8 & 4.2 & \text { Std. Dev., ft } \\ 5 & 22.6 & 1.7 & 9.1 & 0.9 \\ 10 & 26.5 & 1.0 & 11.2 & 0.6 \\ 25 & 27.9 & 0.5 & 12.1 & 0.4 \\ 50 & 28.6 & 0.7 & 12.5 & 0.4 \\ 75 & 29.0 & 0.7 & 12.8 & 0.5 \\ 100 & 29.3 & 0.8 & 13.0 & 0.6 \\ 500 & 30.4 & 1.0 & 13.8 & 0.7\end{array}$

\section{Table D87}

Return Period, Maximum Water Level, and Water Level Standard Deviation for Profile: Rota 87

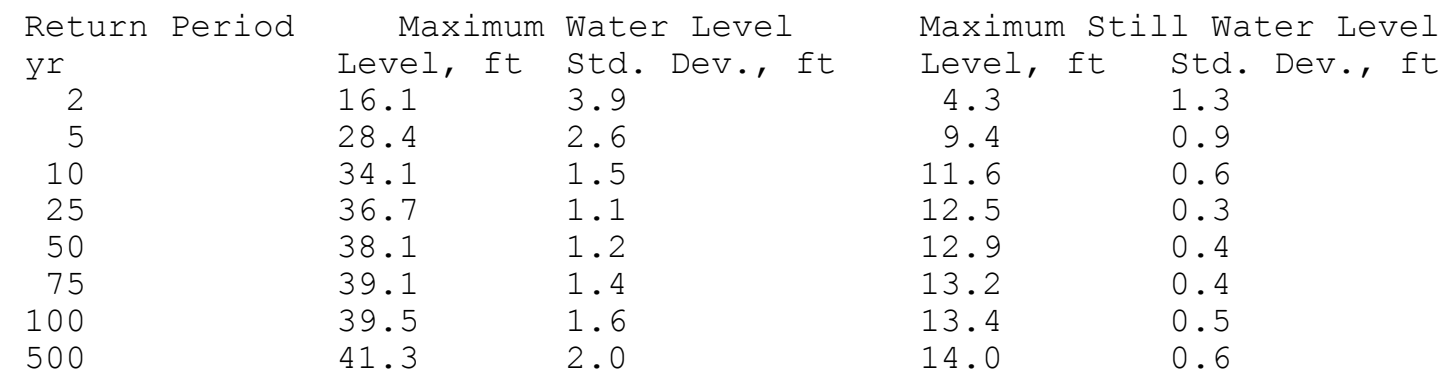




\section{Appendix E Stage-Frequency Relationship Plots}

This appendix contains stage-frequency relationship plots for profiles along the Rota coast. Maximum water level (including storm surge, wave ponding on the reef, and wave runup) with a 100-yr return period and its standard deviation are given for each profile. The plots also include maximum still water level (including storm surge, wave ponding on the reef, and nearshore wave setup) and its standard deviation for each profile and return interval. The reference datum is msl.

Only the maximum still water level information is shown for Profiles 5 through 9. These profiles required a low bluff methodology for mapping flood limits. Hence, wave runup was computed on an imaginary extension of the actual bluff face and it is not meaningful to display in the plots. 

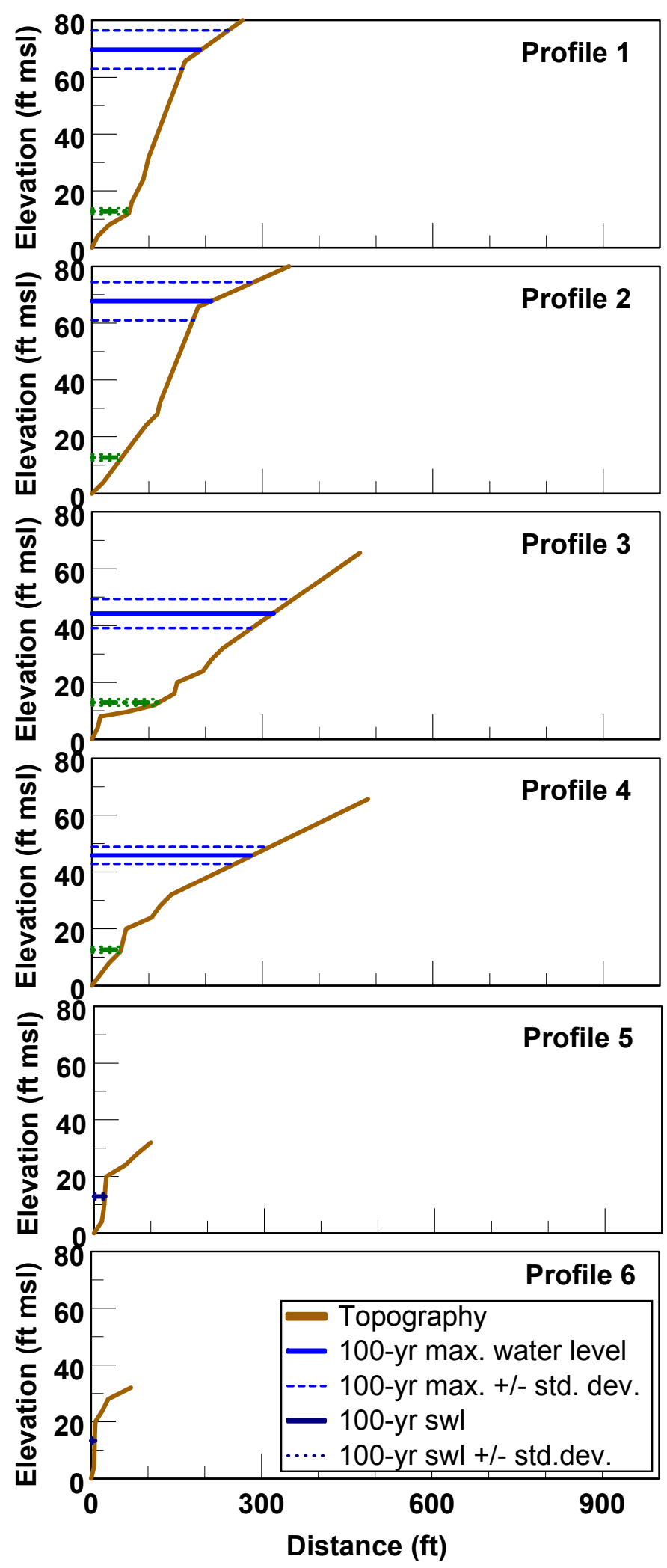

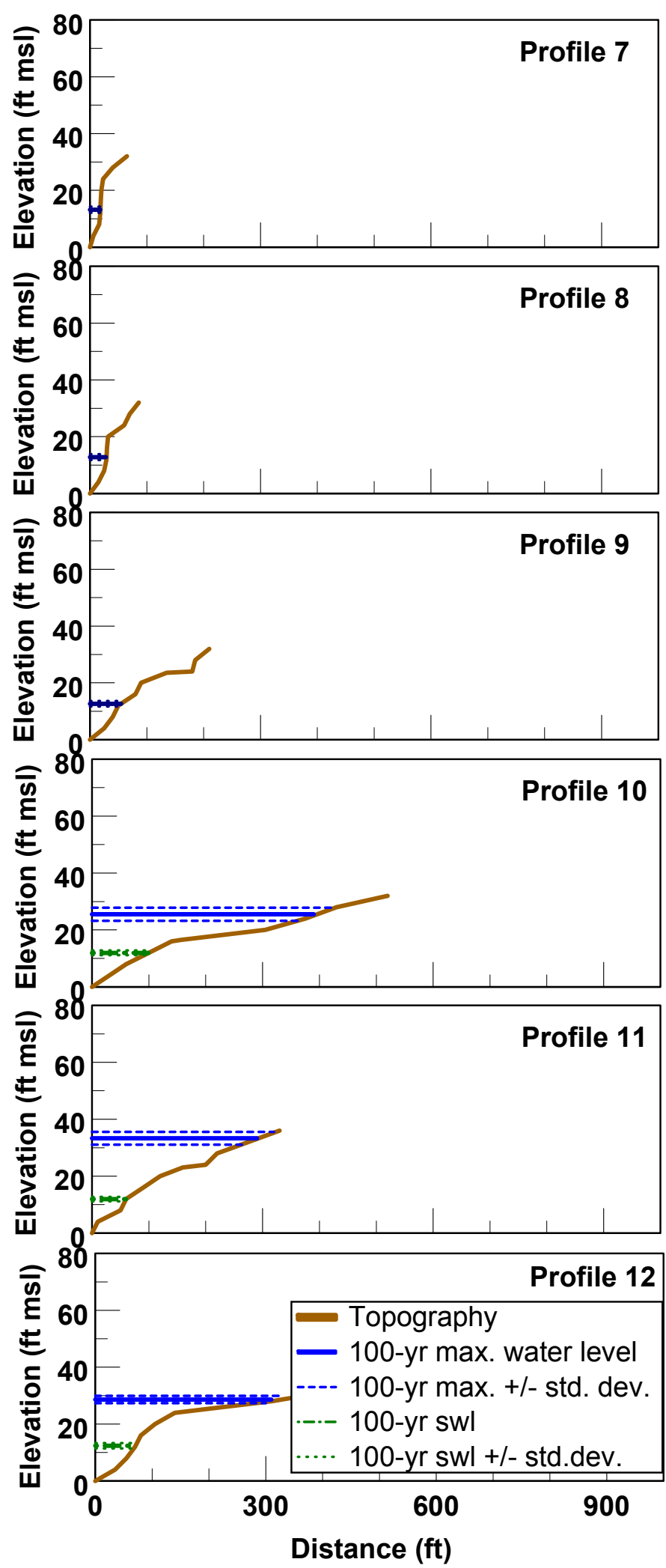

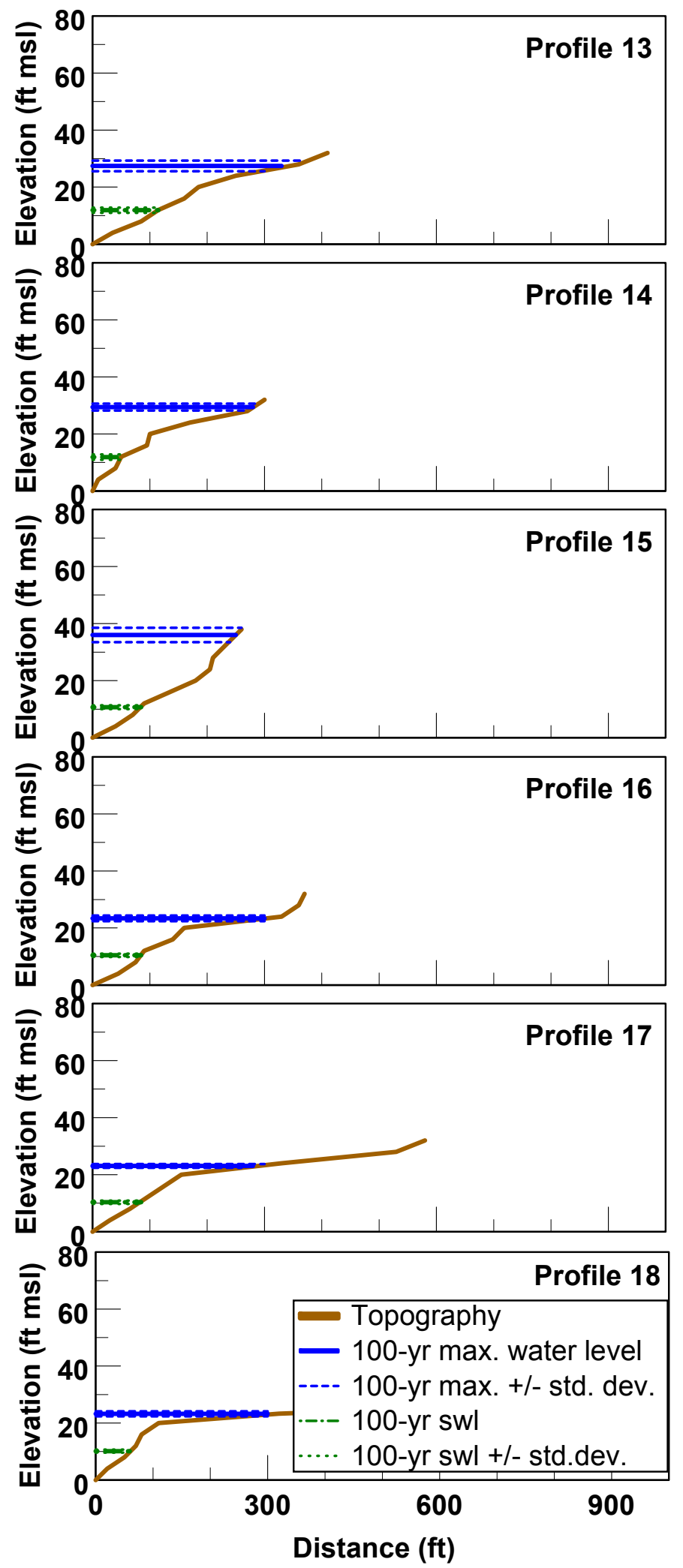

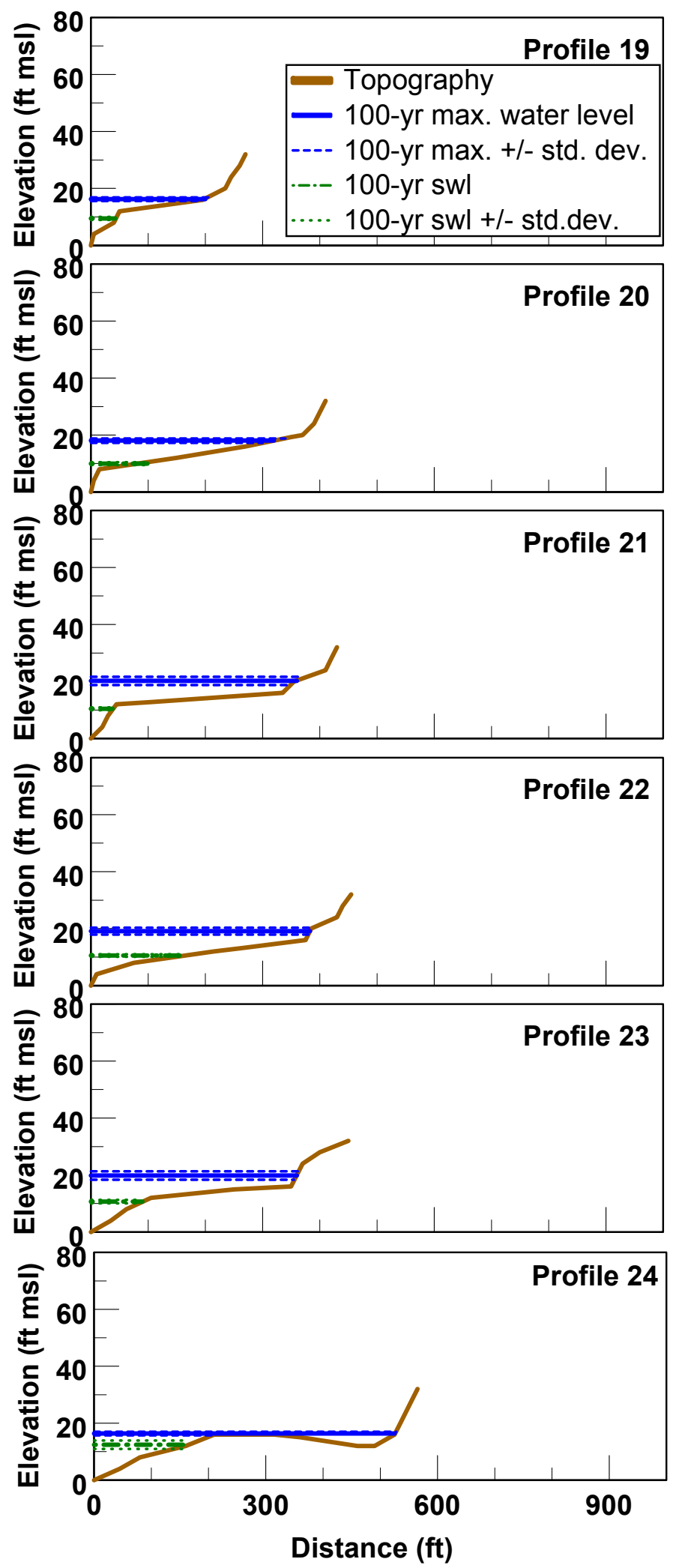

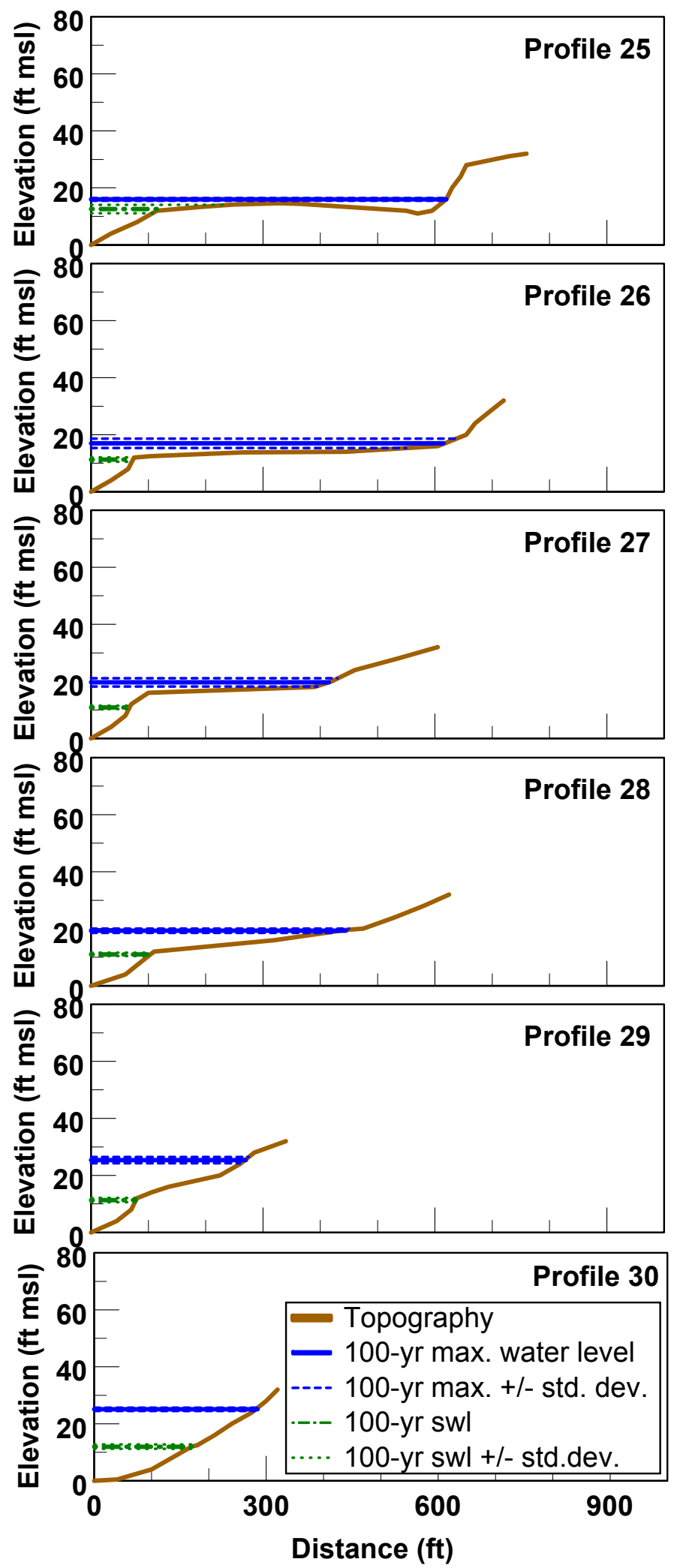

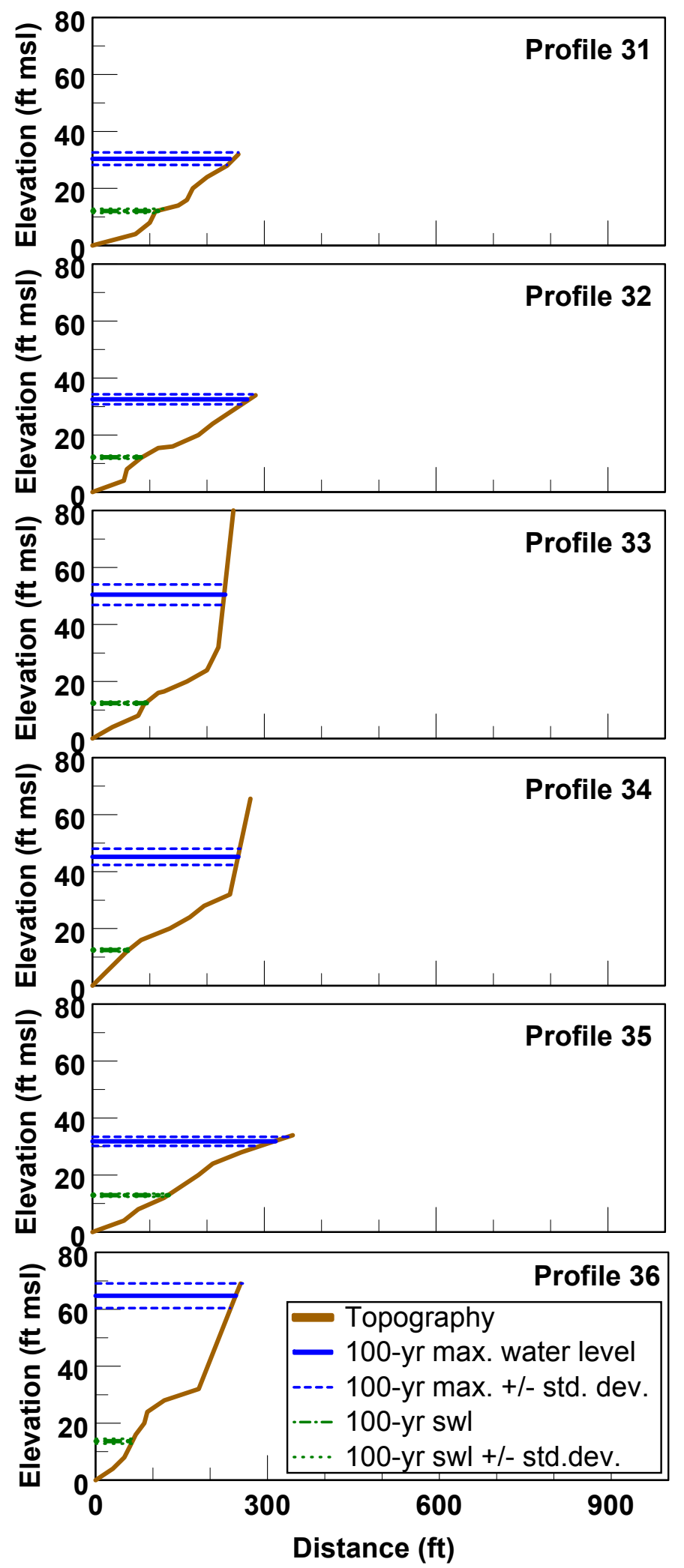

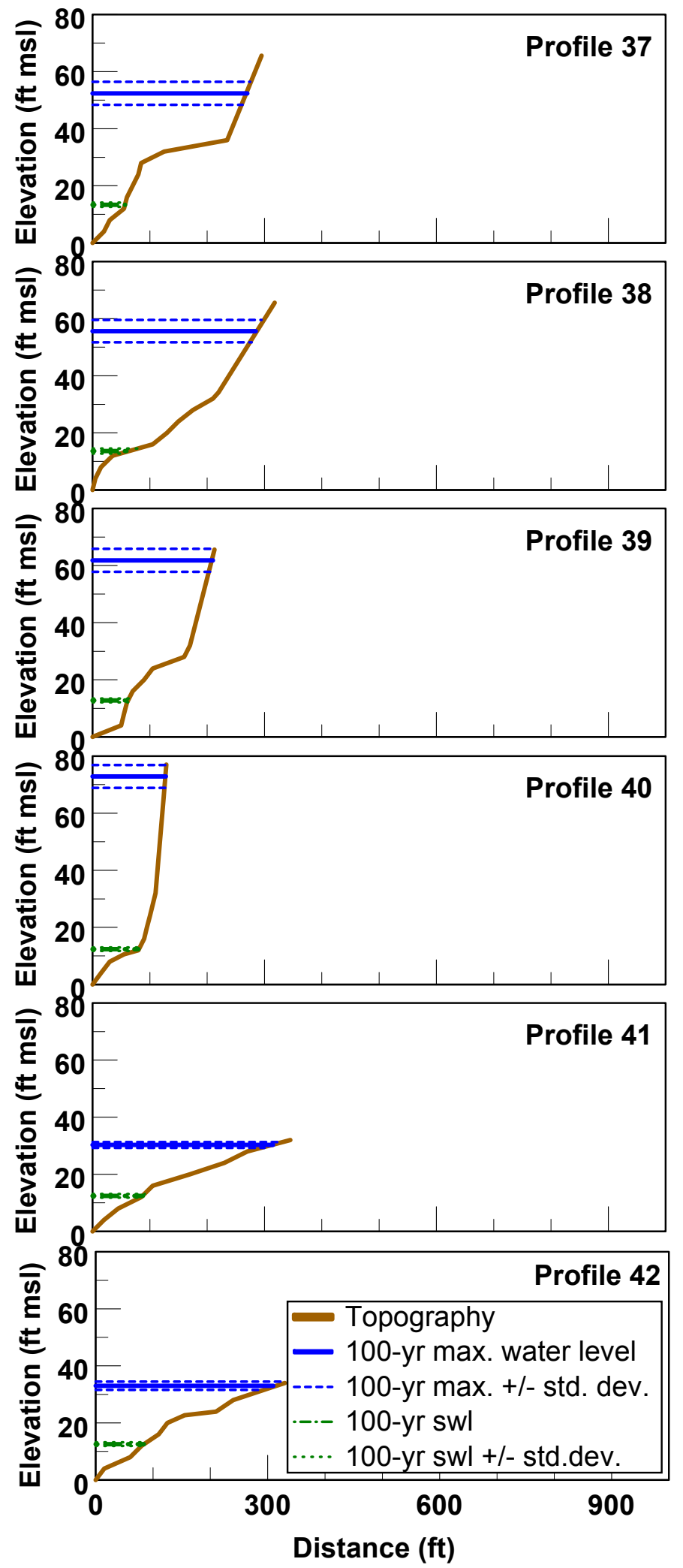

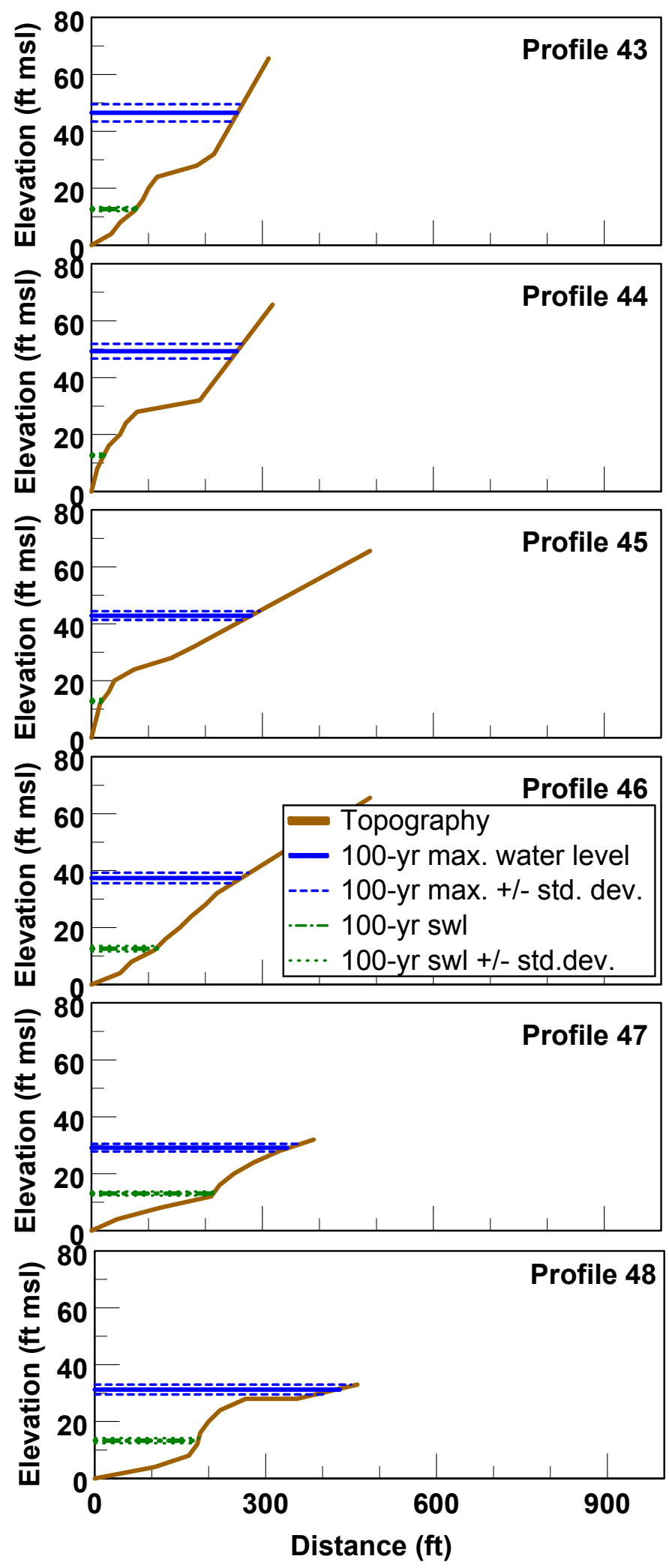


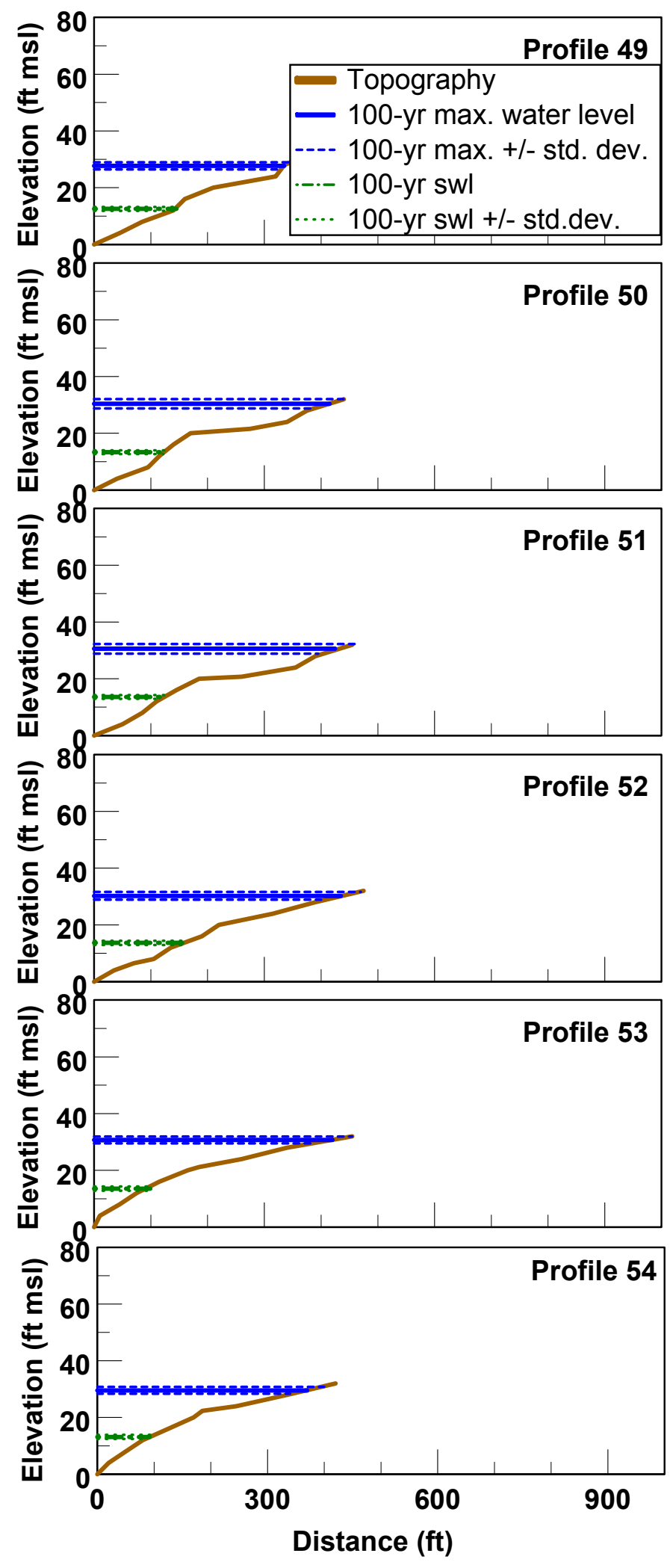




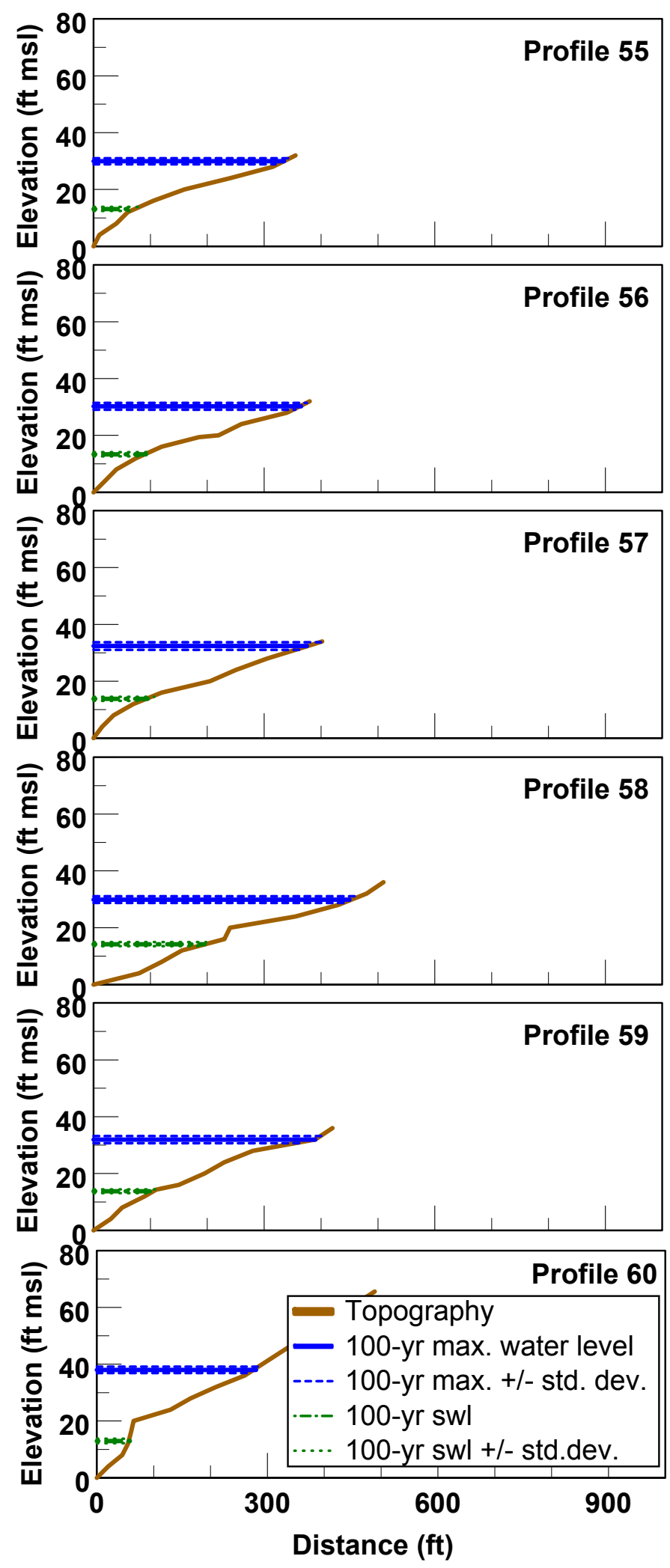



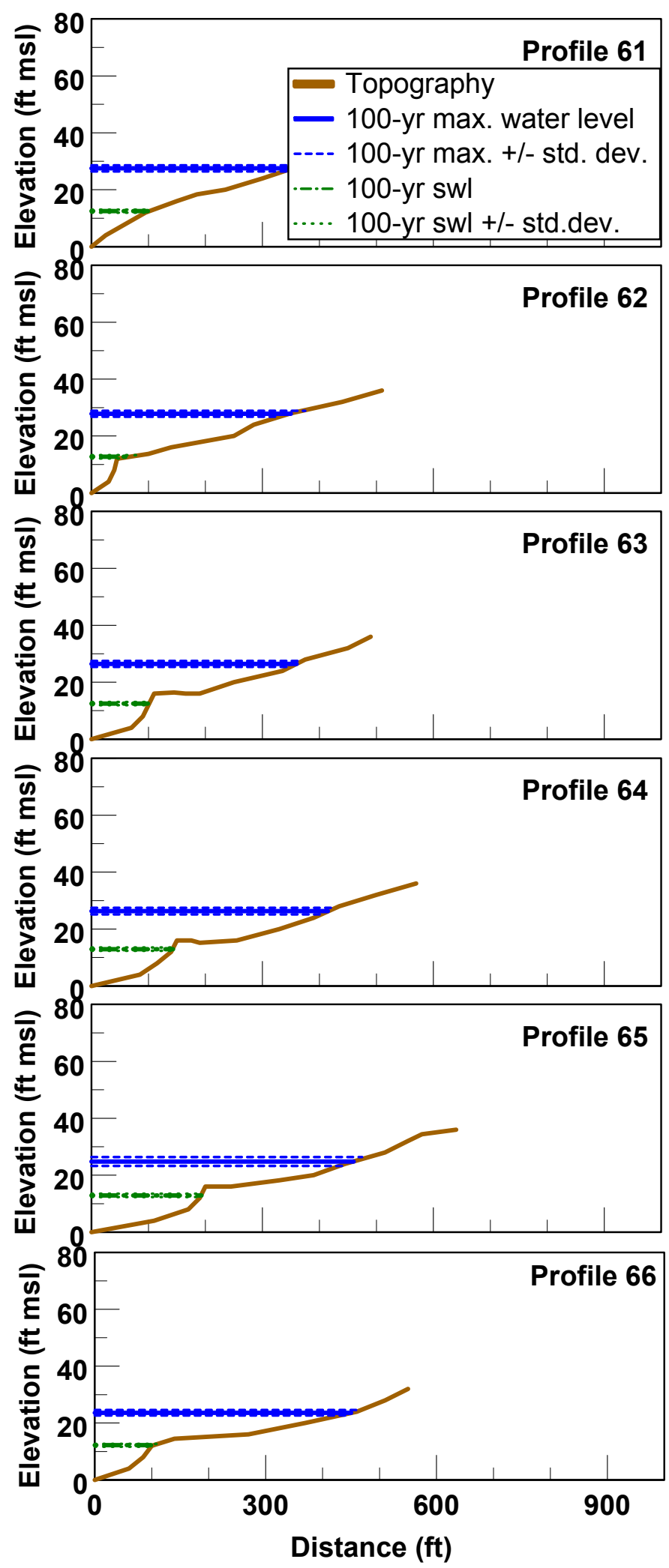

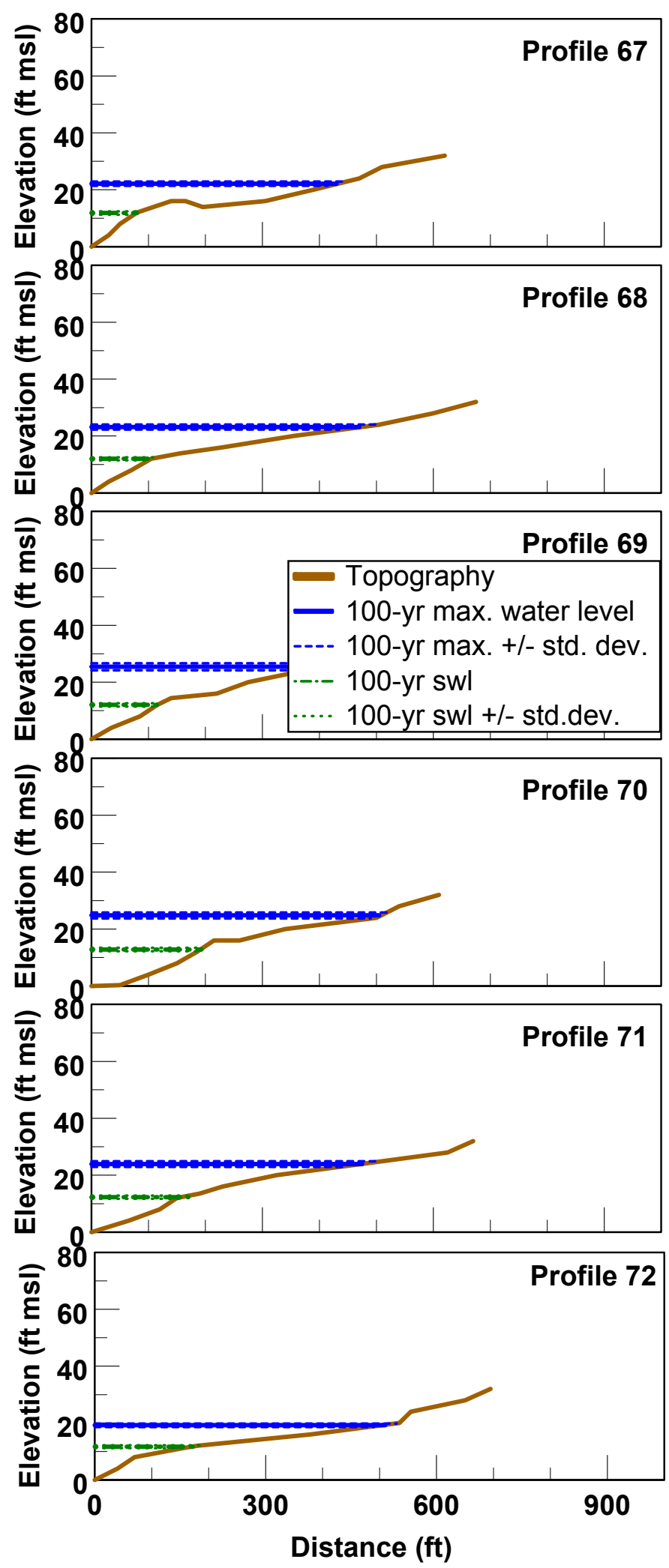


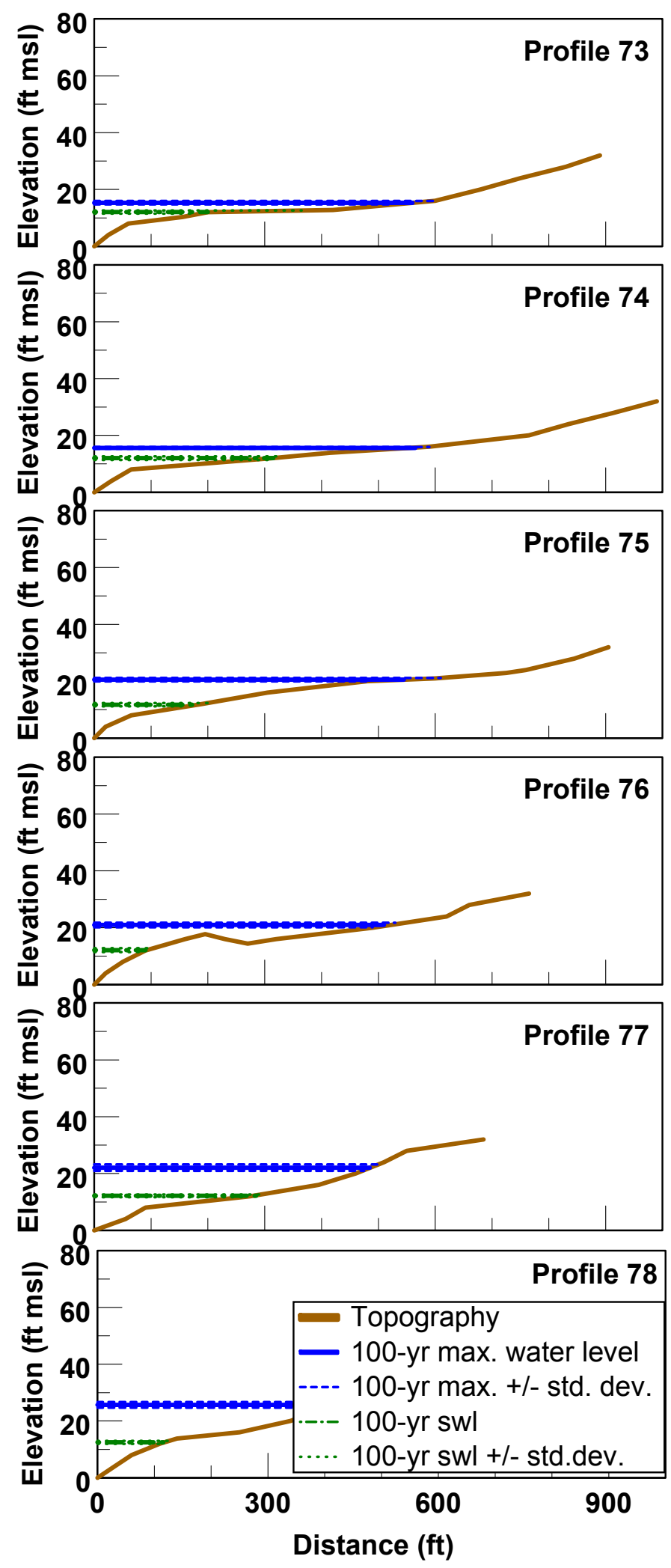



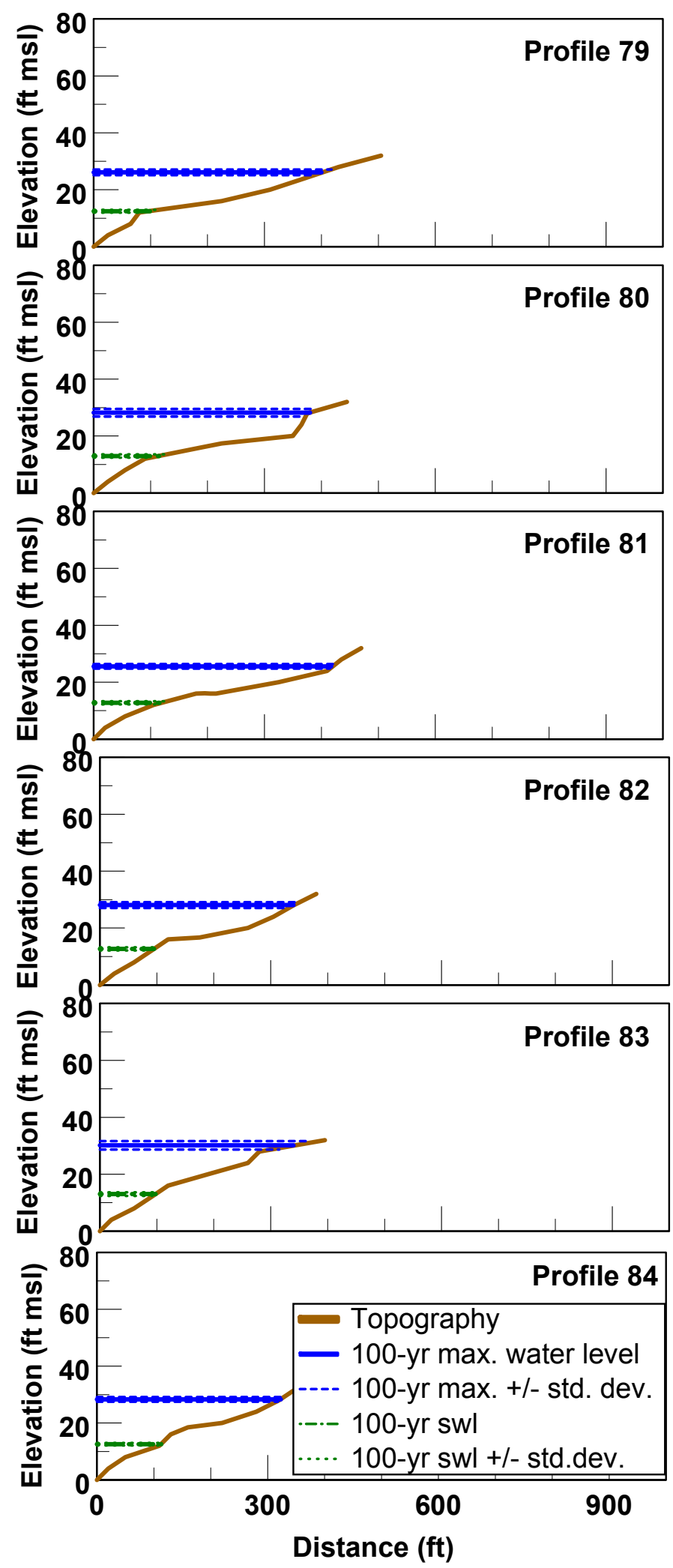


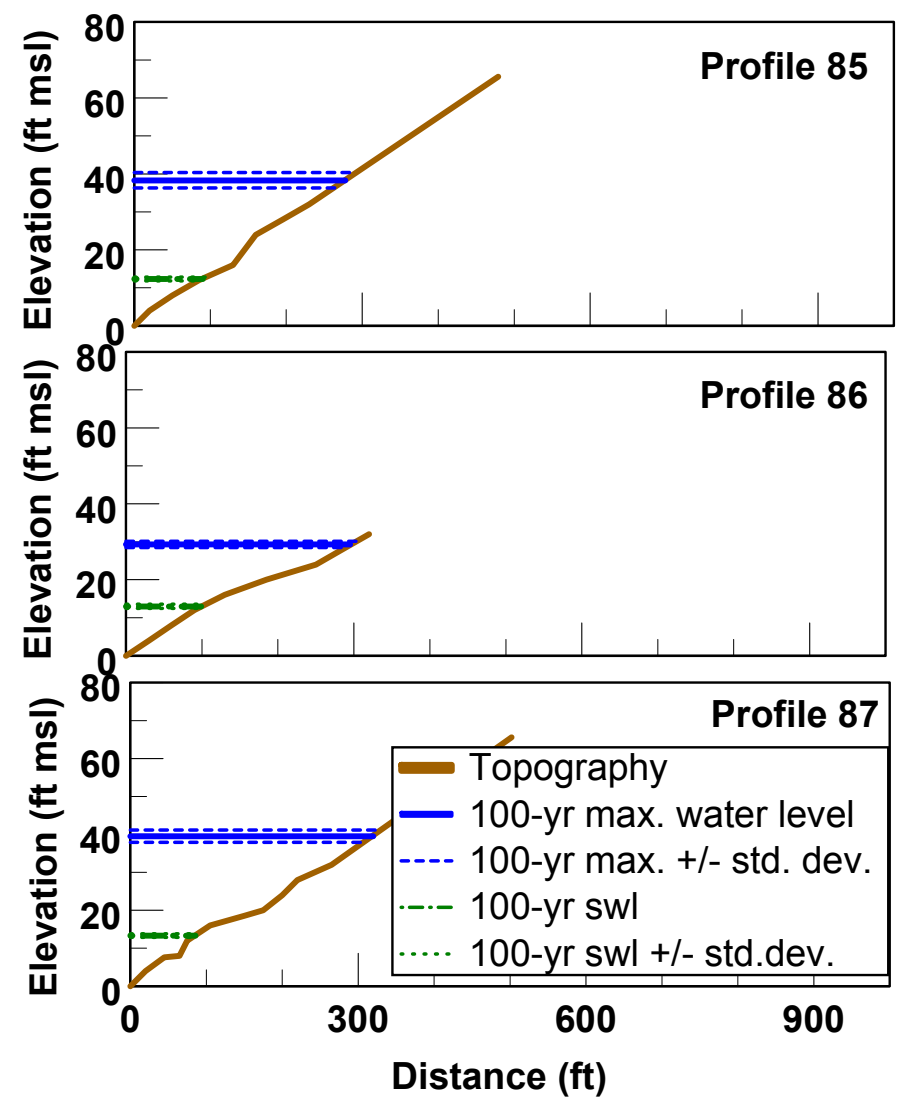




\section{Appendix $\mathbf{F}$ Wave Parameter and Water Level Tables by Storm}

This appendix contains tables of wave parameters and water level components corresponding to the time of maximum water level for each storm at selected profiles along the Rota coast. Tables were generated for all profiles, but only every fourth table is included here to keep the published report to a manageable size. Profiles 4 and 10 are given in place of Profiles 5 and 9 because the special low bluff methodology applied for Profiles 5 through 9 gives fictitious runups which are subsequently reduced prior to flood mapping. Maximum water level includes storm surge, wave ponding on the reef, and wave runup. Reported wave heights and directions are in 10- to 30-m (33- to 98-ft) depth at the seaward edge of the reef. The reported wave heights and water level components correspond to peak total water level at the profile and may not be the maximum values experienced during the storm.

Explanation of each column in the tables is as follows:

Storm No. = identifying number of the storm,

$\mathrm{Hs}=$ significant wave height (average height of the one-third highest waves) in 10- to 30-m (33- to 98-ft) depth at time of maximum total water level,

$\mathrm{H} 1=$ average height of the 1 percent highest waves in 10 - to $30-\mathrm{m}$ (33- to $98-\mathrm{ft})$ depth at time of maximum total water level, level,

$\mathrm{Tp}=$ peak spectral wave period in $10-$ to $30-\mathrm{m}$ (33- to $98-\mathrm{ft})$ depth at time of maximum total water

Dir. = wave direction at time of maximum total water level, in deg azimuth, coming from,

Surge $=$ storm surge at time of maximum total water level,

Ponding = ponding over the reef at time of maximum total water level,

Setup $=$ nearshore wave setup at time of maximum total water level,

Runup $=$ wave runup at shore at time of maximum total water level,

Total $=$ maximum total water during the storm relative to msl datum, including storm surge, ponding, and wave runup. 
Table F1

Wave Parameters and Water Levels by Storm, Profile: Rota 1

\begin{tabular}{|c|c|c|c|c|c|c|c|c|c|}
\hline \multirow[b]{2}{*}{ Storm } & \multicolumn{4}{|c|}{---- Wave Pa } & \multicolumn{5}{|c|}{ 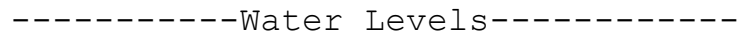 } \\
\hline & Hs & H1 & $\mathrm{Tp}$ & Dir. & Surge & Ponding & Setup & Runup & Total \\
\hline No. & ft & ft & sec & deg az & ft & ft & ft & ft & ft \\
\hline 2348 & 9.2 & 15.3 & 10 & 146 & 0.5 & 2.4 & 1.0 & 16.4 & 19.2 \\
\hline 0150 & 9.2 & 15.3 & 11 & 126 & 0.1 & 2.5 & 1.1 & 20.6 & 23.3 \\
\hline 0853 & 13.1 & 21.9 & 14 & 126 & 1.2 & 3.3 & 1.7 & 35.6 & 40.1 \\
\hline 1953 & 13.8 & 23.0 & 11 & 150 & 0.2 & 3.4 & 1.5 & 21.5 & 25.1 \\
\hline 1557 & 16.4 & 27.4 & 12 & 131 & 0.9 & 3.7 & 1.9 & 27.5 & 32.1 \\
\hline 2057 & 20.4 & 34.0 & 14 & 137 & 0.3 & 4.5 & 2.3 & 35.4 & 40.2 \\
\hline 1861 & 13.8 & 23.0 & 16 & 140 & 0.1 & 3.8 & 1.8 & 42.2 & 46.1 \\
\hline 2762 & 26.6 & 44.4 & 14 & 135 & 0.5 & 5.0 & 3.0 & 40.9 & 46.4 \\
\hline 0163 & 30.2 & 50.4 & 14 & 153 & 1.4 & 5.1 & 3.5 & 45.4 & 51.9 \\
\hline 2563 & 11.1 & 18.6 & 14 & 151 & 0.9 & 3.1 & 1.5 & 34.5 & 38.5 \\
\hline 2965 & 6.2 & 10.4 & 7 & 167 & -0.1 & 1.3 & 0.5 & 8.3 & 9.5 \\
\hline 3367 & 11.1 & 18.6 & 14 & 160 & 1.5 & 2.9 & 1.5 & 36.0 & 40.5 \\
\hline 2168 & 15.4 & 25.8 & 11 & 145 & 0.4 & 3.6 & 1.7 & 23.0 & 27.0 \\
\hline 0571 & 14.1 & 23.6 & 14 & 144 & 0.2 & 3.7 & 1.8 & 34.2 & 38.2 \\
\hline 0676 & 33.8 & 56.4 & 14 & 142 & 1.2 & 5.4 & 3.8 & 47.8 & 54.4 \\
\hline 1977 & 14.1 & 23.6 & 11 & 142 & 0.1 & 3.5 & 1.5 & 21.6 & 25.2 \\
\hline 2379 & 12.8 & 21.4 & 11 & 132 & 0.2 & 3.3 & 1.4 & 20.4 & 23.8 \\
\hline 2187 & 4.3 & 7.1 & 12 & 160 & 0.3 & 0.9 & 0.5 & 13.6 & 14.9 \\
\hline 0188 & 22.6 & 37.8 & 12 & 149 & 0.4 & 4.5 & 2.5 & 32.2 & 37.2 \\
\hline 0289 & 13.8 & 23.0 & 14 & 130 & 0.4 & 3.6 & 1.7 & 34.6 & 38.6 \\
\hline 0190 & 9.8 & 16.4 & 12 & 126 & 0.7 & 2.7 & 1.2 & 25.8 & 29.1 \\
\hline 3190 & 20.4 & 34.0 & 14 & 142 & 0.7 & 4.4 & 2.3 & 36.0 & 41.1 \\
\hline 2691 & 4.9 & 8.2 & 10 & 164 & 0.1 & 1.1 & 0.5 & 12.4 & 13.6 \\
\hline 1592 & 24.3 & 40.5 & 14 & 139 & 0.6 & 4.8 & 2.8 & 39.0 & 44.4 \\
\hline 3192 & 11.1 & 18.6 & 14 & 125 & 0.8 & 3.1 & 1.5 & 34.5 & 38.4 \\
\hline 3594 & 0.0 & 0.0 & 0 & 215 & 0.0 & 0.0 & 0.0 & 0.0 & 0.0 \\
\hline 0597 & 29.5 & 49.3 & 14 & 141 & 0.6 & 5.2 & 3.3 & 43.8 & 49.6 \\
\hline 2997 & 12.2 & 20.3 & 14 & 152 & 1.1 & 3.2 & 1.6 & 35.4 & 39.7 \\
\hline 1367 & 11.8 & 19.7 & 14 & 158 & 1.0 & 3.2 & 1.6 & 35.1 & 39.3 \\
\hline 4367 & 13.8 & 23.0 & 14 & 154 & 1.7 & 3.3 & 1.8 & 36.0 & 41.0 \\
\hline 5163 & 36.4 & 60.8 & 16 & 145 & 2.1 & 5.5 & 4.3 & 57.7 & 65.3 \\
\hline 163 & 23.3 & 38.9 & 12 & 150 & 0.9 & 4.5 & 2.5 & 33.3 & 38.7 \\
\hline
\end{tabular}


Table F4

Wave Parameters and Water Levels by Storm, Profile: Rota 4

\begin{tabular}{|c|c|c|c|c|c|c|c|c|c|}
\hline \multirow{3}{*}{$\begin{array}{c}\text { Storm } \\
\text { No. }\end{array}$} & \multicolumn{4}{|c|}{----Wave Parameters---- } & \multicolumn{5}{|c|}{----------- Water Levels------------ } \\
\hline & $\mathrm{Hs}$ & $\mathrm{H} 1$ & $\mathrm{Tp}$ & Dir. & Surge & Ponding & Setup & Runup & Total \\
\hline & ft & ft & sec & deg az & ft & ft & ft & ft & ft \\
\hline 2348 & 9.5 & 15.9 & 10 & 149 & 0.5 & 2.5 & 1.0 & 18.2 & 21.1 \\
\hline 0150 & 10.5 & 17.5 & 11 & 132 & 0.1 & 2.8 & 1.1 & 19.8 & 22.8 \\
\hline 0853 & 11.8 & 19.7 & 14 & 130 & 1.2 & 3.1 & 1.5 & 28.6 & 32.9 \\
\hline 1953 & 13.8 & 23.0 & 11 & 154 & 0.3 & 3.4 & 1.4 & 19.5 & 23.1 \\
\hline 1557 & 15.7 & 26.3 & 12 & 135 & 0.9 & 3.6 & 1.7 & 22.5 & 27.1 \\
\hline 2057 & 13.8 & 23.0 & 14 & 133 & 0.6 & 3.6 & 1.7 & 28.7 & 32.9 \\
\hline 1861 & 13.5 & 22.5 & 16 & 144 & 0.1 & 3.8 & 1.7 & 31.9 & 35.8 \\
\hline 2762 & 25.9 & 43.3 & 14 & 139 & 0.5 & 5.0 & 2.8 & 29.7 & 35.1 \\
\hline 0163 & 31.2 & 52.1 & 14 & 156 & 1.6 & 5.1 & 3.4 & 31.6 & 38.3 \\
\hline 2563 & 12.5 & 20.8 & 14 & 156 & 0.9 & 3.3 & 1.5 & 28.7 & 32.9 \\
\hline 2965 & 4.0 & 6.6 & 10 & 173 & 0.1 & 0.6 & 0.3 & 10.2 & 10.9 \\
\hline 3367 & 12.5 & 20.8 & 14 & 164 & 1.6 & 3.2 & 1.6 & 28.8 & 33.5 \\
\hline 2168 & 15.4 & 25.8 & 11 & 148 & 0.5 & 3.6 & 1.6 & 19.8 & 23.9 \\
\hline 0571 & 14.1 & 23.6 & 14 & 149 & 0.2 & 3.7 & 1.7 & 28.7 & 32.6 \\
\hline 0676 & 33.5 & 55.9 & 14 & 145 & 1.3 & 5.3 & 3.6 & 32.3 & 39.0 \\
\hline 1977 & 14.1 & 23.6 & 11 & 145 & 0.1 & 3.5 & 1.4 & 19.5 & 23.1 \\
\hline 2379 & 10.2 & 17.0 & 11 & 132 & 0.3 & 2.7 & 1.1 & 19.9 & 22.9 \\
\hline 2187 & 4.9 & 8.2 & 12 & 164 & 0.4 & 1.2 & 0.5 & 18.4 & 20.0 \\
\hline 0188 & 23.0 & 38.4 & 12 & 151 & 0.5 & 4.5 & 2.4 & 26.2 & 31.3 \\
\hline 0289 & 14.8 & 24.7 & 14 & 136 & 0.5 & 3.8 & 1.8 & 28.6 & 32.8 \\
\hline 0190 & 9.5 & 15.9 & 12 & 130 & 0.6 & 2.6 & 1.1 & 22.0 & 25.2 \\
\hline 3190 & 14.1 & 23.6 & 14 & 137 & 0.6 & 3.6 & 1.7 & 28.7 & 32.9 \\
\hline 2691 & 5.6 & 9.3 & 10 & 167 & 0.0 & 1.4 & 0.5 & 16.3 & 17.7 \\
\hline 1592 & 24.0 & 40.0 & 14 & 142 & 0.7 & 4.8 & 2.6 & 29.2 & 34.6 \\
\hline 3192 & 9.8 & 16.4 & 14 & 129 & 0.9 & 2.8 & 1.2 & 27.0 & 30.6 \\
\hline 3594 & 1.0 & 1.6 & 8 & 186 & 0.0 & 0.0 & 0.2 & 6.2 & 6.1 \\
\hline 0597 & 29.2 & 48.8 & 14 & 144 & 0.6 & 5.2 & 3.1 & 30.9 & 36.7 \\
\hline 2997 & 13.5 & 22.5 & 14 & 157 & 1.1 & 3.4 & 1.7 & 28.8 & 33.3 \\
\hline 1367 & 12.8 & 21.4 & 14 & 162 & 1.0 & 3.3 & 1.6 & 28.7 & 33.1 \\
\hline 4367 & 14.8 & 24.7 & 14 & 158 & 1.8 & 3.5 & 1.9 & 28.4 & 33.7 \\
\hline 5163 & 36.8 & 61.4 & 16 & 148 & 2.1 & 5.5 & 4.2 & 36.3 & 43.9 \\
\hline 6163 & 24.3 & 40.5 & 12 & 153 & 0.9 & 4.6 & 2.5 & 27.0 & 32.5 \\
\hline
\end{tabular}


Table F10

Wave Parameters and Water Levels by Storm, Profile: Rota 10

\begin{tabular}{|c|c|c|c|c|c|c|c|c|c|}
\hline \multirow{3}{*}{$\begin{array}{c}\text { Storm } \\
\text { No. }\end{array}$} & \multicolumn{4}{|c|}{----Wave Parameters---- } & \multicolumn{5}{|c|}{----------- Water Levels ------------} \\
\hline & $\mathrm{Hs}$ & $\mathrm{H} 1$ & $\mathrm{Tp}$ & Dir. & Surge & Ponding & Setup & Runup & Total \\
\hline & ft & ft & sec & deg az & ft & ft & ft & ft & ft \\
\hline 2348 & 9.2 & 15.3 & 11 & 190 & 0.4 & 2.5 & 0.7 & 8.7 & 11.6 \\
\hline 0150 & 10.2 & 17.0 & 11 & 158 & 0.1 & 2.8 & 0.8 & 9.1 & 12.0 \\
\hline 0853 & 17.4 & 29.0 & 12 & 163 & 0.3 & 4.0 & 1.4 & 11.8 & 16.1 \\
\hline 1953 & 15.4 & 25.8 & 11 & 174 & 0.3 & 3.6 & 1.2 & 10.3 & 14.3 \\
\hline 1557 & 11.8 & 19.7 & 12 & 156 & 0.9 & 3.0 & 1.0 & 11.1 & 15.1 \\
\hline 2057 & 17.7 & 29.6 & 14 & 161 & 0.3 & 4.2 & 1.5 & 12.4 & 17.0 \\
\hline 1861 & 14.4 & 24.1 & 16 & 169 & 0.1 & 3.9 & 1.2 & 12.8 & 16.8 \\
\hline 2762 & 21.7 & 36.2 & 14 & 157 & 0.7 & 4.5 & 1.9 & 12.4 & 17.6 \\
\hline 0163 & 36.8 & 61.4 & 14 & 174 & 2.0 & 5.4 & 3.2 & 14.0 & 21.3 \\
\hline 2563 & 18.0 & 30.1 & 14 & 187 & 1.5 & 4.0 & 1.7 & 12.2 & 17.7 \\
\hline 2965 & 6.2 & 10.4 & 10 & 194 & 0.1 & 1.6 & 0.4 & 6.3 & 8.1 \\
\hline 3367 & 20.7 & 34.5 & 14 & 191 & 1.9 & 4.2 & 1.9 & 12.1 & 18.1 \\
\hline 2168 & 14.4 & 24.1 & 11 & 187 & 0.5 & 3.4 & 1.1 & 10.4 & 14.4 \\
\hline 0571 & 13.8 & 23.0 & 14 & 167 & 0.2 & 3.7 & 1.1 & 12.6 & 16.4 \\
\hline 0676 & 33.5 & 55.9 & 14 & 168 & 1.4 & 5.3 & 2.8 & 13.1 & 19.7 \\
\hline 1977 & 13.8 & 23.0 & 11 & 163 & 0.1 & 3.4 & 1.0 & 10.4 & 13.9 \\
\hline 2379 & 11.1 & 18.6 & 11 & 160 & 0.1 & 3.0 & 0.9 & 9.6 & 12.7 \\
\hline 2187 & 8.9 & 14.8 & 12 & 189 & 0.5 & 2.5 & 0.7 & 9.2 & 12.2 \\
\hline 0188 & 24.6 & 41.1 & 12 & 168 & 0.5 & 4.7 & 1.9 & 11.4 & 16.6 \\
\hline 0289 & 15.1 & 25.2 & 14 & 163 & 0.3 & 3.8 & 1.3 & 12.5 & 16.7 \\
\hline 0190 & 6.6 & 11.0 & 12 & 154 & 0.4 & 1.9 & 0.5 & 7.6 & 9.8 \\
\hline 3190 & 17.4 & 29.0 & 14 & 162 & 0.7 & 4.1 & 1.5 & 12.3 & 17.1 \\
\hline 2691 & 7.8 & 13.1 & 10 & 189 & 0.0 & 2.2 & 0.5 & 7.2 & 9.3 \\
\hline 1592 & 22.6 & 37.8 & 14 & 161 & 0.7 & 4.6 & 2.0 & 12.3 & 17.7 \\
\hline 3192 & 16.7 & 27.9 & 12 & 160 & 0.2 & 3.9 & 1.3 & 11.9 & 16.1 \\
\hline 3594 & 1.3 & 2.2 & 8 & 206 & 0.0 & 0.0 & 0.2 & 3.4 & 3.4 \\
\hline 0597 & 27.5 & 46.0 & 14 & 160 & 0.7 & 5.0 & 2.3 & 12.6 & 18.4 \\
\hline 2997 & 18.0 & 30.1 & 14 & 193 & 2.0 & 3.8 & 1.8 & 12.1 & 18.0 \\
\hline 1367 & 19.0 & 31.8 & 14 & 185 & 1.4 & 4.1 & 1.8 & 12.3 & 17.8 \\
\hline 4367 & 20.4 & 34.0 & 14 & 182 & 2.0 & 4.1 & 1.9 & 12.1 & 18.2 \\
\hline 5163 & 37.7 & 63.0 & 16 & 163 & 2.2 & 5.5 & 3.4 & 16.3 & 24.0 \\
\hline 6163 & 25.3 & 42.2 & 14 & 190 & 1.2 & 4.7 & 2.2 & 12.3 & 18.3 \\
\hline
\end{tabular}


Table F13

Wave Parameters and Water Levels by Storm, Profile: Rota 13

\begin{tabular}{|c|c|c|c|c|c|c|c|c|c|}
\hline \multirow{3}{*}{$\begin{array}{c}\text { Storm } \\
\text { No. }\end{array}$} & \multicolumn{4}{|c|}{----Wave Parameters---- } & \multicolumn{5}{|c|}{----------- Water Levels ------------} \\
\hline & $\mathrm{Hs}$ & $\mathrm{H} 1$ & $\mathrm{Tp}$ & Dir. & Surge & Ponding & Setup & Runup & Total \\
\hline & ft & ft & sec & deg az & ft & ft & ft & ft & ft \\
\hline 2348 & 10.8 & 18.1 & 11 & 188 & 0.2 & 2.9 & 0.9 & 8.0 & 11.1 \\
\hline 0150 & 8.9 & 14.8 & 11 & 156 & 0.1 & 2.5 & 0.7 & 6.5 & 9.1 \\
\hline 0853 & 17.4 & 29.0 & 12 & 166 & 0.3 & 4.0 & 1.4 & 10.0 & 14.2 \\
\hline 1953 & 15.4 & 25.8 & 11 & 184 & 0.2 & 3.7 & 1.2 & 8.6 & 12.5 \\
\hline 1557 & 10.5 & 17.5 & 12 & 165 & 0.8 & 2.8 & 0.9 & 9.1 & 12.6 \\
\hline 2057 & 16.4 & 27.4 & 14 & 170 & 0.2 & 4.1 & 1.5 & 13.3 & 17.5 \\
\hline 1861 & 13.8 & 23.0 & 16 & 179 & 0.0 & 3.8 & 1.2 & 13.1 & 17.0 \\
\hline 2762 & 19.7 & 32.9 & 14 & 164 & 0.5 & 4.4 & 1.8 & 14.7 & 19.6 \\
\hline 0163 & 37.1 & 61.9 & 14 & 186 & 1.8 & 5.4 & 3.3 & 16.7 & 23.9 \\
\hline 2563 & 25.3 & 42.2 & 14 & 204 & 0.9 & 4.8 & 2.2 & 14.5 & 20.2 \\
\hline 2965 & 7.8 & 13.1 & 10 & 205 & 0.1 & 2.1 & 0.6 & 5.4 & 7.6 \\
\hline 3367 & 26.9 & 44.9 & 14 & 201 & 1.4 & 4.8 & 2.4 & 14.7 & 20.9 \\
\hline 2168 & 17.1 & 28.5 & 11 & 176 & 0.6 & 3.8 & 1.4 & 8.8 & 13.1 \\
\hline 0571 & 13.1 & 21.9 & 14 & 176 & 0.1 & 3.6 & 1.1 & 11.2 & 14.9 \\
\hline 0676 & 31.5 & 52.6 & 14 & 176 & 1.1 & 5.2 & 2.7 & 15.2 & 21.5 \\
\hline 1977 & 13.5 & 22.5 & 11 & 171 & 0.1 & 3.4 & 1.1 & 8.8 & 12.2 \\
\hline 2379 & 10.2 & 17.0 & 11 & 168 & 0.1 & 2.8 & 0.8 & 7.4 & 10.3 \\
\hline 2187 & 12.5 & 20.8 & 12 & 202 & 0.5 & 3.2 & 1.1 & 9.6 & 13.3 \\
\hline 0188 & 23.6 & 39.4 & 12 & 176 & 0.4 & 4.6 & 1.9 & 10.7 & 15.7 \\
\hline 0289 & 14.1 & 23.6 & 14 & 175 & 0.3 & 3.7 & 1.3 & 11.7 & 15.7 \\
\hline 0190 & 8.2 & 13.7 & 11 & 206 & 0.3 & 2.3 & 0.6 & 6.2 & 8.8 \\
\hline 3190 & 16.7 & 27.9 & 14 & 172 & 0.6 & 4.0 & 1.5 & 14.0 & 18.6 \\
\hline 2691 & 9.2 & 15.3 & 10 & 199 & 0.0 & 2.5 & 0.7 & 5.9 & 8.4 \\
\hline 1592 & 18.7 & 31.2 & 14 & 165 & 0.6 & 4.2 & 1.7 & 14.8 & 19.6 \\
\hline 3192 & 15.7 & 26.3 & 12 & 168 & 0.1 & 3.8 & 1.3 & 10.1 & 14.0 \\
\hline 3594 & 1.0 & 1.6 & 9 & 218 & 0.0 & 0.0 & 0.2 & 3.3 & 3.3 \\
\hline 0597 & 26.9 & 44.9 & 14 & 171 & 0.5 & 5.1 & 2.3 & 14.7 & 20.2 \\
\hline 2997 & 27.2 & 45.5 & 14 & 201 & 1.4 & 4.9 & 2.4 & 14.7 & 21.0 \\
\hline 1367 & 24.3 & 40.5 & 14 & 198 & 1.2 & 4.7 & 2.2 & 14.4 & 20.2 \\
\hline 4367 & 22.0 & 36.7 & 14 & 191 & 1.8 & 4.3 & 2.1 & 14.1 & 20.2 \\
\hline 5163 & 36.8 & 61.4 & 16 & 173 & 1.8 & 5.6 & 3.4 & 18.3 & 25.7 \\
\hline 6163 & 26.9 & 44.9 & 14 & 199 & 1.0 & 4.9 & 2.3 & 14.7 & 20.7 \\
\hline
\end{tabular}


Table F17

Wave Parameters and Water Levels by Storm, Profile: Rota 17

\begin{tabular}{|c|c|c|c|c|c|c|c|c|c|}
\hline \multirow{2}{*}{ Storm } & \multicolumn{4}{|c|}{--Wave Parameters---- } & \multicolumn{5}{|c|}{ 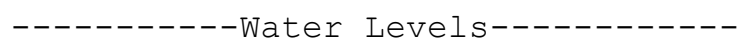 } \\
\hline & $\mathrm{Hs}$ & $\mathrm{H} 1$ & $\mathrm{Tp}$ & Dir. & Surge & Ponding & Setup & Runup & Total \\
\hline No. & ft & ft & sec & deg az & ft & ft & ft & ft & ft \\
\hline 2348 & 16.4 & 27.4 & 10 & 339 & 0.9 & 3.5 & 0.7 & 7.9 & 12.3 \\
\hline 0150 & 4.0 & 6.6 & 14 & 285 & 0.0 & 1.0 & 0.3 & 6.6 & 7.6 \\
\hline 0853 & 14.1 & 23.6 & 16 & 295 & 0.1 & 3.9 & 0.6 & 11.8 & 15.7 \\
\hline 1953 & 9.2 & 15.3 & 14 & 295 & 0.0 & 2.8 & 0.4 & 8.9 & 11.8 \\
\hline 1557 & 11.5 & 19.2 & 11 & 294 & 0.1 & 3.0 & 0.5 & 7.0 & 10.1 \\
\hline 2057 & 16.4 & 27.4 & 14 & 340 & 0.4 & 4.0 & 0.7 & 10.2 & 14.7 \\
\hline 1861 & 8.5 & 14.2 & 12 & 339 & 0.1 & 2.5 & 0.4 & 7.2 & 9.8 \\
\hline 2762 & 23.0 & 38.4 & 14 & 342 & 1.1 & 4.6 & 0.9 & 12.8 & 18.5 \\
\hline 0163 & 28.9 & 48.2 & 14 & 297 & 0.6 & 5.2 & 1.0 & 14.1 & 19.9 \\
\hline 2563 & 39.3 & 65.7 & 16 & 303 & 1.1 & 5.8 & 1.6 & 14.5 & 21.5 \\
\hline 2965 & 11.1 & 18.6 & 14 & 321 & 0.0 & 3.3 & 0.5 & 9.4 & 12.6 \\
\hline 3367 & 29.9 & 49.9 & 16 & 340 & 2.3 & 5.0 & 1.4 & 14.0 & 21.3 \\
\hline 2168 & 11.8 & 19.7 & 11 & 296 & 0.1 & 3.1 & 0.5 & 7.0 & 10.2 \\
\hline 0571 & 7.5 & 12.6 & 16 & 292 & 0.3 & 2.5 & 0.4 & 10.1 & 12.9 \\
\hline 0676 & 16.0 & 26.8 & 16 & 300 & 0.2 & 4.2 & 0.6 & 12.4 & 16.7 \\
\hline 1977 & 12.8 & 21.4 & 12 & 344 & 0.5 & 3.3 & 0.6 & 8.1 & 11.9 \\
\hline 2379 & 6.6 & 11.0 & 10 & 349 & 0.2 & 1.7 & 0.4 & 5.3 & 7.2 \\
\hline 2187 & 22.0 & 36.7 & 14 & 313 & 0.3 & 4.7 & 0.8 & 11.4 & 16.4 \\
\hline 0188 & 24.6 & 41.1 & 16 & 342 & 1.6 & 4.7 & 1.1 & 14.1 & 20.4 \\
\hline 0289 & 17.1 & 28.5 & 12 & 333 & 0.4 & 3.9 & 0.6 & 9.0 & 13.3 \\
\hline 0190 & 23.0 & 38.4 & 14 & 333 & 0.5 & 4.7 & 0.8 & 11.9 & 17.1 \\
\hline 3190 & 15.4 & 25.8 & 12 & 342 & 0.3 & 3.7 & 0.6 & 8.5 & 12.5 \\
\hline 2691 & 19.3 & 32.3 & 14 & 328 & -0.1 & 4.5 & 0.7 & 10.3 & 14.7 \\
\hline 1592 & 15.4 & 25.8 & 14 & 340 & 0.6 & 3.8 & 0.6 & 10.2 & 14.7 \\
\hline 3192 & 18.0 & 30.1 & 14 & 339 & 0.8 & 4.1 & 0.7 & 10.9 & 15.8 \\
\hline 3594 & 9.8 & 16.4 & 11 & 332 & 0.0 & 2.7 & 0.4 & 6.5 & 9.2 \\
\hline 0597 & 26.2 & 43.8 & 14 & 345 & 1.0 & 4.9 & 1.0 & 13.8 & 19.8 \\
\hline 2997 & 39.3 & 65.7 & 14 & 330 & 2.0 & 5.5 & 1.7 & 13.7 & 21.2 \\
\hline 1367 & 35.7 & 59.7 & 16 & 341 & 2.2 & 5.4 & 1.6 & 14.3 & 21.9 \\
\hline 4367 & 29.9 & 49.9 & 16 & 343 & 2.0 & 5.1 & 1.3 & 14.1 & 21.1 \\
\hline 5163 & 33.8 & 56.4 & 16 & 337 & 0.8 & 5.6 & 1.3 & 14.5 & 20.9 \\
\hline 6163 & 25.6 & 42.7 & 14 & 291 & 0.5 & 4.9 & 0.9 & 12.8 & 18.2 \\
\hline
\end{tabular}


Table F21

Wave Parameters and Water Levels by Storm, Profile: Rota 21

\begin{tabular}{|c|c|c|c|c|c|c|c|c|c|}
\hline \multirow{3}{*}{$\begin{array}{c}\text { Storm } \\
\text { No. }\end{array}$} & \multicolumn{4}{|c|}{----Wave Parameters---- } & \multicolumn{5}{|c|}{----------- Water Levels------------ } \\
\hline & $\mathrm{Hs}$ & $\mathrm{H} 1$ & $\mathrm{Tp}$ & Dir. & Surge & Ponding & Setup & Runup & Total \\
\hline & ft & ft & sec & deg az & ft & ft & ft & ft & ft \\
\hline 2348 & 16.7 & 27.9 & 10 & 341 & 1.0 & 3.5 & 0.7 & 8.2 & 12.8 \\
\hline 0150 & 4.9 & 8.2 & 11 & 351 & 0.0 & 1.2 & 0.3 & 10.2 & 11.4 \\
\hline 0853 & 13.8 & 23.0 & 16 & 299 & 0.0 & 3.8 & 0.6 & 9.3 & 13.2 \\
\hline 1953 & 8.9 & 14.8 & 14 & 298 & 0.0 & 2.8 & 0.4 & 9.9 & 12.7 \\
\hline 1557 & 10.8 & 18.1 & 11 & 294 & 0.2 & 2.9 & 0.5 & 9.4 & 12.4 \\
\hline 2057 & 17.7 & 29.6 & 14 & 344 & 0.4 & 4.2 & 0.7 & 8.6 & 13.1 \\
\hline 1861 & 9.5 & 15.9 & 12 & 343 & 0.0 & 2.7 & 0.4 & 9.7 & 12.4 \\
\hline 2762 & 24.3 & 40.5 & 14 & 345 & 1.2 & 4.7 & 0.9 & 8.2 & 14.0 \\
\hline 0163 & 28.6 & 47.7 & 14 & 299 & 0.8 & 5.1 & 1.0 & 8.4 & 14.3 \\
\hline 2563 & 40.0 & 66.8 & 14 & 325 & 2.0 & 5.5 & 1.6 & 9.0 & 16.5 \\
\hline 2965 & 10.8 & 18.1 & 14 & 324 & 0.0 & 3.2 & 0.5 & 9.6 & 12.8 \\
\hline 3367 & 31.8 & 53.1 & 16 & 343 & 2.4 & 5.1 & 1.4 & 9.4 & 16.9 \\
\hline 2168 & 11.5 & 19.2 & 11 & 298 & 0.1 & 3.0 & 0.5 & 9.3 & 12.4 \\
\hline 0571 & 7.2 & 12.1 & 16 & 296 & 0.3 & 2.4 & 0.4 & 10.1 & 12.8 \\
\hline 0676 & 15.4 & 25.8 & 16 & 303 & 0.1 & 4.1 & 0.6 & 9.0 & 13.2 \\
\hline 1977 & 13.8 & 23.0 & 12 & 347 & 0.3 & 3.5 & 0.6 & 8.9 & 12.7 \\
\hline 2379 & 7.2 & 12.1 & 10 & 353 & 0.1 & 1.9 & 0.4 & 10.1 & 12.1 \\
\hline 2187 & 22.6 & 37.8 & 14 & 320 & 0.3 & 4.7 & 0.8 & 8.3 & 13.3 \\
\hline 0188 & 26.6 & 44.4 & 16 & 345 & 1.6 & 4.9 & 1.1 & 8.6 & 15.1 \\
\hline 0289 & 17.1 & 28.5 & 12 & 337 & 0.5 & 3.9 & 0.6 & 8.5 & 12.9 \\
\hline 0190 & 23.6 & 39.4 & 14 & 336 & 0.5 & 4.8 & 0.8 & 8.2 & 13.5 \\
\hline 3190 & 10.8 & 18.1 & 14 & 348 & 0.3 & 3.1 & 0.5 & 9.4 & 12.9 \\
\hline 2691 & 19.0 & 31.8 & 14 & 331 & -0.1 & 4.4 & 0.6 & 8.7 & 13.1 \\
\hline 1592 & 16.7 & 27.9 & 14 & 344 & 0.6 & 4.0 & 0.7 & 8.6 & 13.1 \\
\hline 3192 & 19.3 & 32.3 & 14 & 343 & 0.7 & 4.3 & 0.7 & 8.3 & 13.3 \\
\hline 3594 & 10.2 & 17.0 & 11 & 334 & 0.0 & 2.8 & 0.4 & 9.6 & 12.4 \\
\hline 0597 & 27.5 & 46.0 & 14 & 348 & 1.1 & 5.0 & 1.0 & 8.3 & 14.4 \\
\hline 2997 & 39.7 & 66.3 & 14 & 309 & 2.3 & 5.5 & 1.6 & 9.1 & 16.8 \\
\hline 1367 & 36.8 & 61.4 & 16 & 344 & 2.4 & 5.4 & 1.6 & 10.7 & 18.5 \\
\hline 4367 & 31.5 & 52.6 & 16 & 347 & 2.0 & 5.2 & 1.3 & 8.8 & 15.9 \\
\hline 5163 & 34.4 & 57.5 & 16 & 340 & 1.0 & 5.6 & 1.3 & 9.0 & 15.6 \\
\hline 6163 & 24.9 & 41.6 & 14 & 294 & 0.6 & 4.9 & 0.9 & 8.2 & 13.7 \\
\hline
\end{tabular}


Table F25

Wave Parameters and Water Levels by Storm, Profile: Rota 25

\begin{tabular}{|c|c|c|c|c|c|c|c|c|c|}
\hline \multirow{3}{*}{$\begin{array}{c}\text { Storm } \\
\text { No. }\end{array}$} & \multicolumn{4}{|c|}{----Wave Parameters---- } & \multicolumn{5}{|c|}{----------- Water Levels------------ } \\
\hline & $\mathrm{Hs}$ & $\mathrm{H} 1$ & $\mathrm{Tp}$ & Dir. & Surge & Ponding & Setup & Runup & Total \\
\hline & ft & ft & sec & deg az & ft & ft & ft & ft & ft \\
\hline 2348 & 16.7 & 27.9 & 10 & 341 & 1.0 & 3.5 & 0.6 & 6.1 & 10.6 \\
\hline 0150 & 3.6 & 6.0 & 14 & 289 & -0.1 & 0.8 & 0.3 & 5.2 & 6.0 \\
\hline 0853 & 13.8 & 23.0 & 16 & 299 & 0.0 & 3.8 & 0.6 & 8.9 & 12.8 \\
\hline 1953 & 8.9 & 14.8 & 14 & 298 & 0.0 & 2.8 & 0.4 & 6.8 & 9.5 \\
\hline 1557 & 11.1 & 18.6 & 11 & 297 & 0.1 & 3.0 & 0.5 & 5.2 & 8.4 \\
\hline 2057 & 17.7 & 29.6 & 14 & 344 & 0.4 & 4.2 & 0.7 & 8.0 & 12.5 \\
\hline 1861 & 9.5 & 15.9 & 12 & 343 & 0.0 & 2.7 & 0.4 & 5.6 & 8.4 \\
\hline 2762 & 19.0 & 31.8 & 16 & 345 & 0.4 & 4.5 & 0.7 & 9.9 & 14.8 \\
\hline 0163 & 26.6 & 44.4 & 14 & 316 & 0.5 & 5.0 & 0.9 & 9.1 & 14.6 \\
\hline 2563 & 19.7 & 32.9 & 16 & 293 & 0.2 & 4.6 & 0.7 & 9.9 & 14.7 \\
\hline 2965 & 15.7 & 26.3 & 12 & 325 & 0.1 & 3.8 & 0.6 & 6.4 & 10.3 \\
\hline 3367 & 23.3 & 38.9 & 14 & 349 & 0.9 & 4.6 & 0.8 & 8.9 & 14.5 \\
\hline 2168 & 11.5 & 19.2 & 11 & 298 & 0.1 & 3.0 & 0.5 & 5.3 & 8.4 \\
\hline 0571 & 7.2 & 12.1 & 16 & 296 & 0.3 & 2.4 & 0.4 & 7.8 & 10.4 \\
\hline 0676 & 15.4 & 25.8 & 16 & 303 & 0.2 & 4.1 & 0.6 & 9.3 & 13.5 \\
\hline 1977 & 13.8 & 23.0 & 12 & 347 & 0.4 & 3.5 & 0.6 & 6.3 & 10.1 \\
\hline 2379 & 7.2 & 12.1 & 10 & 353 & 0.1 & 1.9 & 0.4 & 4.4 & 6.4 \\
\hline 2187 & 22.6 & 37.8 & 14 & 320 & 0.4 & 4.7 & 0.8 & 8.7 & 13.8 \\
\hline 0188 & 25.9 & 43.3 & 12 & 345 & 0.9 & 4.7 & 0.9 & 7.8 & 13.4 \\
\hline 0289 & 17.7 & 29.6 & 12 & 336 & 0.4 & 4.0 & 0.6 & 7.0 & 11.4 \\
\hline 0190 & 23.6 & 39.4 & 14 & 336 & 0.5 & 4.8 & 0.8 & 9.0 & 14.3 \\
\hline 3190 & 10.8 & 18.1 & 14 & 348 & 0.3 & 3.1 & 0.5 & 7.4 & 10.8 \\
\hline 2691 & 19.3 & 32.3 & 14 & 333 & -0.1 & 4.5 & 0.6 & 8.0 & 12.4 \\
\hline 1592 & 16.7 & 27.9 & 14 & 344 & 0.6 & 4.0 & 0.7 & 8.0 & 12.6 \\
\hline 3192 & 19.3 & 32.3 & 14 & 343 & 0.7 & 4.3 & 0.7 & 8.4 & 13.4 \\
\hline 3594 & 10.2 & 17.0 & 11 & 334 & 0.0 & 2.8 & 0.4 & 5.0 & 7.8 \\
\hline 0597 & 23.3 & 38.9 & 14 & 353 & 0.9 & 4.6 & 0.8 & 8.9 & 14.4 \\
\hline 2997 & 19.7 & 32.9 & 16 & 296 & 0.2 & 4.6 & 0.7 & 9.9 & 14.8 \\
\hline 1367 & 19.0 & 31.8 & 16 & 288 & 0.1 & 4.5 & 0.7 & 9.8 & 14.4 \\
\hline 4367 & 21.7 & 36.2 & 14 & 352 & 0.8 & 4.5 & 0.8 & 8.9 & 14.2 \\
\hline 5163 & 26.9 & 44.9 & 14 & 321 & 0.3 & 5.1 & 0.9 & 9.0 & 14.4 \\
\hline 6163 & 19.3 & 32.3 & 16 & 333 & 0.1 & 4.6 & 0.7 & 9.8 & 14.5 \\
\hline
\end{tabular}


Table F29

Wave Parameters and Water Levels by Storm, Profile: Rota 29

\begin{tabular}{|c|c|c|c|c|c|c|c|c|c|}
\hline \multirow{3}{*}{$\begin{array}{c}\text { Storm } \\
\text { No. }\end{array}$} & \multicolumn{4}{|c|}{----Wave Parameters---- } & \multicolumn{5}{|c|}{----------- Water Levels ------------} \\
\hline & $\mathrm{Hs}$ & $\mathrm{H} 1$ & $\mathrm{Tp}$ & Dir. & Surge & Ponding & Setup & Runup & Total \\
\hline & ft & ft & sec & deg az & ft & ft & ft & ft & ft \\
\hline 2348 & 16.7 & 27.9 & 10 & 341 & 0.9 & 3.6 & 0.8 & 8.9 & 13.4 \\
\hline 0150 & 3.6 & 6.0 & 14 & 289 & -0.1 & 0.8 & 0.3 & 4.6 & 5.4 \\
\hline 0853 & 13.8 & 23.0 & 16 & 299 & 0.0 & 3.8 & 0.7 & 11.4 & 15.3 \\
\hline 1953 & 8.9 & 14.8 & 14 & 298 & 0.0 & 2.8 & 0.5 & 9.6 & 12.4 \\
\hline 1557 & 11.1 & 18.6 & 11 & 297 & 0.1 & 3.0 & 0.5 & 7.2 & 10.3 \\
\hline 2057 & 17.7 & 29.6 & 14 & 344 & 0.2 & 4.2 & 0.8 & 10.8 & 15.2 \\
\hline 1861 & 9.5 & 15.9 & 12 & 343 & 0.0 & 2.8 & 0.5 & 7.2 & 9.9 \\
\hline 2762 & 24.3 & 40.5 & 14 & 345 & 0.9 & 4.7 & 1.2 & 11.8 & 17.4 \\
\hline 0163 & 28.6 & 47.7 & 14 & 299 & 0.9 & 5.1 & 1.5 & 12.1 & 18.0 \\
\hline 2563 & 38.7 & 64.7 & 16 & 305 & 1.3 & 5.8 & 2.2 & 16.1 & 23.2 \\
\hline 2965 & 15.7 & 26.3 & 12 & 325 & 0.1 & 3.8 & 0.7 & 9.5 & 13.4 \\
\hline 3367 & 31.8 & 53.1 & 16 & 343 & 2.3 & 5.1 & 2.0 & 15.5 & 22.9 \\
\hline 2168 & 11.5 & 19.2 & 11 & 298 & 0.1 & 3.0 & 0.5 & 7.3 & 10.5 \\
\hline 0571 & 7.2 & 12.1 & 16 & 296 & 0.3 & 2.4 & 0.4 & 10.4 & 13.0 \\
\hline 0676 & 15.4 & 25.8 & 16 & 303 & 0.2 & 4.1 & 0.7 & 11.6 & 15.8 \\
\hline 1977 & 13.8 & 23.0 & 12 & 347 & 0.3 & 3.5 & 0.6 & 9.2 & 13.0 \\
\hline 2379 & 7.2 & 12.1 & 10 & 353 & 0.1 & 1.9 & 0.4 & 4.1 & 6.1 \\
\hline 2187 & 22.6 & 37.8 & 14 & 320 & 0.4 & 4.7 & 1.1 & 11.6 & 16.7 \\
\hline 0188 & 26.6 & 44.4 & 16 & 345 & 1.4 & 4.9 & 1.5 & 13.3 & 19.6 \\
\hline 0289 & 17.7 & 29.6 & 12 & 336 & 0.4 & 4.0 & 0.8 & 10.1 & 14.5 \\
\hline 0190 & 23.6 & 39.4 & 14 & 336 & 0.5 & 4.8 & 1.1 & 11.7 & 17.0 \\
\hline 3190 & 16.4 & 27.4 & 12 & 345 & 0.2 & 3.9 & 0.7 & 9.7 & 13.8 \\
\hline 2691 & 19.3 & 32.3 & 14 & 333 & -0.1 & 4.5 & 0.9 & 10.9 & 15.4 \\
\hline 1592 & 16.7 & 27.9 & 14 & 344 & 0.5 & 4.0 & 0.8 & 10.7 & 15.1 \\
\hline 3192 & 19.3 & 32.3 & 14 & 343 & 0.5 & 4.3 & 0.9 & 11.2 & 16.1 \\
\hline 3594 & 10.2 & 17.0 & 11 & 334 & 0.0 & 2.8 & 0.5 & 6.2 & 8.9 \\
\hline 0597 & 27.5 & 46.0 & 14 & 348 & 0.9 & 5.0 & 1.4 & 11.9 & 17.8 \\
\hline 2997 & 33.1 & 55.3 & 16 & 328 & 1.4 & 5.4 & 1.9 & 15.1 & 22.0 \\
\hline 1367 & 36.8 & 61.4 & 16 & 344 & 2.3 & 5.4 & 2.2 & 16.2 & 24.0 \\
\hline 4367 & 31.5 & 52.6 & 16 & 347 & 1.7 & 5.2 & 1.9 & 15.0 & 22.0 \\
\hline 5163 & 34.4 & 57.5 & 16 & 340 & 1.0 & 5.6 & 1.9 & 15.2 & 21.8 \\
\hline 6163 & 24.9 & 41.6 & 14 & 294 & 0.7 & 4.8 & 1.2 & 11.8 & 17.4 \\
\hline
\end{tabular}


Table F33

Wave Parameters and Water Levels by Storm, Profile: Rota 33

\begin{tabular}{|c|c|c|c|c|c|c|c|c|c|}
\hline \multirow{3}{*}{$\begin{array}{c}\text { Storm } \\
\text { No. }\end{array}$} & \multicolumn{4}{|c|}{----Wave Parameters---- } & \multicolumn{5}{|c|}{----------- Water Levels ------------} \\
\hline & $\mathrm{Hs}$ & $\mathrm{H} 1$ & $\mathrm{Tp}$ & Dir. & Surge & Ponding & Setup & Runup & Total \\
\hline & ft & ft & sec & deg az & ft & ft & ft & ft & ft \\
\hline 2348 & 13.1 & 21.9 & 11 & 347 & 0.9 & 3.2 & 1.2 & 12.1 & 16.1 \\
\hline 0150 & 5.6 & 9.3 & 11 & 354 & 0.0 & 1.5 & 0.4 & 5.0 & 6.4 \\
\hline 0853 & 15.7 & 26.3 & 14 & 350 & 0.7 & 3.8 & 1.5 & 16.7 & 21.2 \\
\hline 1953 & 11.1 & 18.6 & 11 & 348 & 0.5 & 2.9 & 1.0 & 11.8 & 15.2 \\
\hline 1557 & 10.5 & 17.5 & 11 & 300 & 0.1 & 2.8 & 0.9 & 11.1 & 14.0 \\
\hline 2057 & 19.0 & 31.8 & 14 & 348 & 0.3 & 4.3 & 1.8 & 17.0 & 21.7 \\
\hline 1861 & 10.2 & 17.0 & 12 & 347 & 0.0 & 2.9 & 0.9 & 11.8 & 14.7 \\
\hline 2762 & 22.0 & 36.7 & 16 & 348 & 0.6 & 4.7 & 2.2 & 26.4 & 31.8 \\
\hline 0163 & 27.9 & 46.6 & 14 & 301 & 0.7 & 5.1 & 2.5 & 17.5 & 23.3 \\
\hline 2563 & 39.3 & 65.7 & 16 & 330 & 1.6 & 5.7 & 3.7 & 36.1 & 43.4 \\
\hline 2965 & 15.7 & 26.3 & 12 & 327 & 0.0 & 3.8 & 1.3 & 13.5 & 17.4 \\
\hline 3367 & 33.5 & 55.9 & 16 & 346 & 2.3 & 5.2 & 3.3 & 31.3 & 38.8 \\
\hline 2168 & 11.1 & 18.6 & 11 & 301 & 0.1 & 3.0 & 0.9 & 11.5 & 14.5 \\
\hline 0571 & 10.5 & 17.5 & 12 & 348 & 0.1 & 3.0 & 0.9 & 12.2 & 15.2 \\
\hline 0676 & 14.8 & 24.7 & 16 & 306 & 0.2 & 4.0 & 1.4 & 18.2 & 22.3 \\
\hline 1977 & 14.8 & 24.7 & 12 & 351 & 0.4 & 3.6 & 1.3 & 13.5 & 17.5 \\
\hline 2379 & 7.8 & 13.1 & 10 & 356 & 0.1 & 2.1 & 0.6 & 6.1 & 8.3 \\
\hline 2187 & 20.0 & 33.4 & 14 & 314 & 0.2 & 4.5 & 1.8 & 16.9 & 21.6 \\
\hline 0188 & 22.3 & 37.3 & 16 & 351 & 1.3 & 4.6 & 2.3 & 27.4 & 33.2 \\
\hline 0289 & 15.4 & 25.8 & 12 & 346 & 0.4 & 3.7 & 1.4 & 13.4 & 17.6 \\
\hline 0190 & 18.4 & 30.7 & 14 & 348 & 0.7 & 4.2 & 1.8 & 17.1 & 22.0 \\
\hline 3190 & 11.8 & 19.7 & 14 & 352 & 0.3 & 3.3 & 1.1 & 14.4 & 18.0 \\
\hline 2691 & 19.0 & 31.8 & 14 & 330 & -0.1 & 4.4 & 1.7 & 17.0 & 21.4 \\
\hline 1592 & 17.7 & 29.6 & 14 & 348 & 0.5 & 4.1 & 1.7 & 17.1 & 21.8 \\
\hline 3192 & 19.3 & 32.3 & 14 & 346 & 0.6 & 4.3 & 1.8 & 17.0 & 21.9 \\
\hline 3594 & 10.5 & 17.5 & 11 & 337 & 0.0 & 2.9 & 0.9 & 10.9 & 13.7 \\
\hline 0597 & 28.9 & 48.2 & 14 & 351 & 0.9 & 5.1 & 2.6 & 17.9 & 23.9 \\
\hline 2997 & 40.4 & 67.4 & 14 & 334 & 2.0 & 5.6 & 3.7 & 28.4 & 36.0 \\
\hline 1367 & 38.1 & 63.6 & 16 & 347 & 2.2 & 5.5 & 3.7 & 36.0 & 43.7 \\
\hline 4367 & 33.5 & 55.9 & 16 & 350 & 1.8 & 5.3 & 3.2 & 30.1 & 37.2 \\
\hline 5163 & 34.8 & 58.1 & 16 & 342 & 0.9 & 5.6 & 3.2 & 29.5 & 36.0 \\
\hline 6163 & 18.7 & 31.2 & 16 & 336 & 0.1 & 4.5 & 1.8 & 23.5 & 28.1 \\
\hline
\end{tabular}


Table F37

Wave Parameters and Water Levels by Storm, Profile: Rota 37

\begin{tabular}{|c|c|c|c|c|c|c|c|c|c|}
\hline \multirow{3}{*}{$\begin{array}{c}\text { Storm } \\
\text { No. }\end{array}$} & \multicolumn{4}{|c|}{----Wave Parameters---- } & \multicolumn{5}{|c|}{----------- Water Levels------------ } \\
\hline & $\mathrm{Hs}$ & $\mathrm{H} 1$ & $\mathrm{Tp}$ & Dir. & Surge & Ponding & Setup & Runup & Total \\
\hline & ft & ft & sec & deg az & ft & ft & ft & ft & ft \\
\hline 2348 & 16.9 & 28.3 & 10 & 343 & 0.9 & 3.6 & 1.7 & 22.2 & 26.7 \\
\hline 0150 & 5.4 & 9.0 & 11 & 355 & 0.0 & 1.4 & 0.5 & 15.0 & 16.4 \\
\hline 0853 & 13.3 & 22.2 & 16 & 302 & 0.1 & 3.8 & 1.6 & 30.2 & 34.1 \\
\hline 1953 & 8.4 & 14.0 & 14 & 302 & 0.0 & 2.6 & 0.9 & 26.4 & 29.1 \\
\hline 1557 & 8.5 & 14.2 & 11 & 354 & 0.8 & 2.2 & 1.0 & 22.3 & 25.3 \\
\hline 2057 & 14.3 & 23.9 & 14 & 349 & 0.3 & 3.7 & 1.7 & 28.7 & 32.7 \\
\hline 1861 & 9.8 & 16.4 & 12 & 347 & 0.0 & 2.8 & 1.1 & 25.3 & 28.1 \\
\hline 2762 & 19.8 & 33.0 & 16 & 348 & 0.6 & 4.5 & 2.4 & 29.8 & 34.9 \\
\hline 0163 & 28.6 & 47.8 & 14 & 312 & 0.5 & 5.2 & 3.1 & 28.6 & 34.3 \\
\hline 2563 & 39.5 & 65.9 & 16 & 330 & 1.7 & 5.7 & 4.4 & 38.5 & 45.9 \\
\hline 2965 & 10.9 & 18.2 & 14 & 326 & 0.0 & 3.2 & 1.3 & 28.4 & 31.6 \\
\hline 3367 & 32.8 & 54.7 & 16 & 346 & 2.3 & 5.2 & 3.8 & 33.7 & 41.2 \\
\hline 2168 & 8.5 & 14.2 & 12 & 349 & 0.4 & 2.4 & 1.0 & 24.8 & 27.6 \\
\hline 0571 & 6.8 & 11.3 & 16 & 300 & 0.3 & 2.2 & 0.8 & 26.3 & 28.9 \\
\hline 0676 & 15.0 & 25.1 & 16 & 306 & 0.2 & 4.0 & 1.9 & 30.4 & 34.6 \\
\hline 1977 & 14.4 & 24.0 & 12 & 351 & 0.5 & 3.5 & 1.6 & 24.4 & 28.4 \\
\hline 2379 & 7.6 & 12.7 & 10 & 356 & 0.2 & 2.0 & 0.8 & 17.6 & 19.8 \\
\hline 2187 & 23.1 & 38.5 & 14 & 330 & 0.4 & 4.7 & 2.5 & 27.9 & 33.0 \\
\hline 0188 & 27.2 & 45.5 & 16 & 349 & 1.7 & 4.9 & 3.2 & 29.1 & 35.8 \\
\hline 0289 & 17.8 & 29.8 & 12 & 338 & 0.4 & 4.0 & 1.9 & 25.7 & 30.1 \\
\hline 0190 & 23.8 & 39.7 & 14 & 338 & 0.4 & 4.8 & 2.6 & 28.2 & 33.4 \\
\hline 3190 & 11.4 & 19.0 & 14 & 352 & 0.4 & 3.2 & 1.4 & 28.6 & 32.2 \\
\hline 2691 & 14.9 & 24.9 & 14 & 320 & 0.0 & 3.9 & 1.7 & 28.7 & 32.6 \\
\hline 1592 & 14.3 & 23.8 & 14 & 351 & 0.6 & 3.6 & 1.7 & 28.5 & 32.8 \\
\hline 3192 & 20.1 & 33.6 & 14 & 347 & 0.7 & 4.4 & 2.2 & 27.8 & 32.9 \\
\hline 3594 & 10.4 & 17.3 & 11 & 337 & 0.0 & 2.8 & 1.1 & 21.3 & 24.1 \\
\hline 0597 & 28.3 & 47.3 & 14 & 351 & 1.1 & 5.0 & 3.1 & 28.4 & 34.5 \\
\hline 2997 & 32.8 & 54.7 & 16 & 330 & 1.4 & 5.4 & 3.7 & 32.3 & 39.0 \\
\hline 1367 & 37.6 & 62.8 & 16 & 347 & 2.2 & 5.5 & 4.3 & 39.1 & 46.8 \\
\hline 4367 & 32.8 & 54.7 & 16 & 350 & 2.0 & 5.3 & 3.8 & 33.1 & 40.3 \\
\hline 5163 & 34.6 & 57.7 & 16 & 342 & 0.9 & 5.6 & 3.9 & 33.7 & 40.2 \\
\hline 6163 & 18.8 & 31.4 & 16 & 336 & 0.1 & 4.5 & 2.3 & 30.3 & 34.9 \\
\hline
\end{tabular}


Table F41

Wave Parameters and Water Levels by Storm, Profile: Rota 41

\begin{tabular}{|c|c|c|c|c|c|c|c|c|c|}
\hline \multirow{3}{*}{$\begin{array}{c}\text { Storm } \\
\text { No. }\end{array}$} & \multicolumn{4}{|c|}{----Wave Parameters---- } & \multicolumn{5}{|c|}{----------- Water Levels ------------} \\
\hline & Hs & $\mathrm{H} 1$ & $\mathrm{Tp}$ & Dir. & Surge & Ponding & Setup & Runup & Total \\
\hline & ft & ft & sec & deg az & ft & ft & ft & ft & ft \\
\hline 2348 & 11.8 & 19.7 & 11 & 342 & 0.9 & 2.9 & 1.1 & 13.1 & 16.9 \\
\hline 0150 & 4.0 & 6.6 & 14 & 285 & 0.0 & 1.0 & 0.3 & 9.1 & 10.1 \\
\hline 0853 & 14.1 & 23.6 & 16 & 295 & 0.1 & 3.9 & 1.4 & 17.4 & 21.4 \\
\hline 1953 & 9.2 & 15.3 & 14 & 295 & 0.0 & 2.8 & 0.8 & 13.9 & 16.8 \\
\hline 1557 & 11.5 & 19.2 & 11 & 294 & 0.1 & 3.0 & 1.0 & 13.3 & 16.4 \\
\hline 2057 & 16.4 & 27.4 & 14 & 340 & 0.4 & 4.0 & 1.6 & 16.6 & 21.0 \\
\hline 1861 & 8.5 & 14.2 & 12 & 339 & 0.0 & 2.5 & 0.7 & 12.0 & 14.5 \\
\hline 2762 & 18.7 & 31.2 & 16 & 341 & 0.8 & 4.3 & 2.0 & 18.7 & 23.8 \\
\hline 0163 & 28.9 & 48.2 & 14 & 297 & 0.7 & 5.1 & 2.7 & 16.7 & 22.6 \\
\hline 2563 & 39.3 & 65.7 & 16 & 303 & 1.2 & 5.8 & 3.8 & 21.2 & 28.3 \\
\hline 2965 & 11.1 & 18.6 & 14 & 321 & 0.0 & 3.3 & 1.0 & 15.1 & 18.4 \\
\hline 3367 & 29.9 & 49.9 & 16 & 340 & 2.3 & 5.0 & 3.1 & 19.3 & 26.6 \\
\hline 2168 & 11.8 & 19.7 & 11 & 296 & 0.1 & 3.1 & 1.0 & 13.3 & 16.5 \\
\hline 0571 & 7.5 & 12.6 & 16 & 292 & 0.3 & 2.5 & 0.7 & 14.4 & 17.2 \\
\hline 0676 & 16.0 & 26.8 & 16 & 300 & 0.2 & 4.2 & 1.6 & 18.2 & 22.5 \\
\hline 1977 & 12.8 & 21.4 & 12 & 344 & 0.5 & 3.3 & 1.2 & 14.3 & 18.0 \\
\hline 2379 & 6.6 & 11.0 & 10 & 349 & 0.2 & 1.7 & 0.5 & 8.5 & 10.4 \\
\hline 2187 & 17.4 & 29.0 & 14 & 306 & 0.1 & 4.2 & 1.7 & 16.6 & 20.9 \\
\hline 0188 & 21.7 & 36.2 & 16 & 344 & 1.6 & 4.5 & 2.4 & 18.8 & 24.9 \\
\hline 0289 & 14.1 & 23.6 & 12 & 339 & 0.5 & 3.5 & 1.3 & 14.2 & 18.2 \\
\hline 0190 & 16.4 & 27.4 & 14 & 341 & 0.7 & 3.9 & 1.7 & 16.5 & 21.1 \\
\hline 3190 & 14.8 & 24.7 & 12 & 342 & 0.2 & 3.7 & 1.3 & 14.3 & 18.1 \\
\hline 2691 & 19.3 & 32.3 & 14 & 324 & 0.0 & 4.5 & 1.8 & 16.5 & 20.9 \\
\hline 1592 & 15.4 & 25.8 & 14 & 340 & 0.7 & 3.8 & 1.6 & 16.5 & 20.9 \\
\hline 3192 & 18.0 & 30.1 & 14 & 339 & 0.7 & 4.1 & 1.8 & 16.4 & 21.2 \\
\hline 3594 & 9.8 & 16.4 & 11 & 331 & -0.1 & 2.7 & 0.8 & 12.4 & 15.1 \\
\hline 0597 & 26.2 & 43.8 & 14 & 345 & 1.1 & 4.8 & 2.5 & 16.4 & 22.3 \\
\hline 2997 & 39.3 & 65.7 & 14 & 330 & 2.0 & 5.5 & 3.7 & 19.7 & 27.2 \\
\hline 1367 & 35.7 & 59.7 & 16 & 341 & 2.1 & 5.4 & 3.6 & 20.6 & 28.1 \\
\hline 4367 & 29.9 & 49.9 & 16 & 343 & 2.0 & 5.1 & 3.0 & 19.1 & 26.1 \\
\hline 5163 & 33.8 & 56.4 & 16 & 337 & 0.9 & 5.6 & 3.3 & 19.8 & 26.3 \\
\hline 6163 & 19.3 & 32.3 & 16 & 329 & 0.1 & 4.6 & 2.0 & 18.8 & 23.5 \\
\hline
\end{tabular}


Table F45

Wave Parameters and Water Levels by Storm, Profile: Rota 45

\begin{tabular}{|c|c|c|c|c|c|c|c|c|c|}
\hline \multirow{3}{*}{$\begin{array}{c}\text { Storm } \\
\text { No. }\end{array}$} & \multicolumn{4}{|c|}{----Wave Parameters---- } & \multicolumn{5}{|c|}{----------- Water Levels ------------} \\
\hline & $\mathrm{Hs}$ & $\mathrm{H} 1$ & $\mathrm{Tp}$ & Dir. & Surge & Ponding & Setup & Runup & Total \\
\hline & ft & ft & sec & deg az & ft & ft & ft & ft & ft \\
\hline 2348 & 11.8 & 19.7 & 11 & 342 & 0.9 & 2.9 & 1.1 & 21.8 & 25.6 \\
\hline 0150 & 4.9 & 8.2 & 10 & 349 & -0.1 & 1.1 & 0.4 & 14.8 & 15.9 \\
\hline 0853 & 14.1 & 23.6 & 16 & 295 & 0.1 & 3.9 & 1.4 & 28.1 & 32.0 \\
\hline 1953 & 9.2 & 15.3 & 14 & 295 & 0.0 & 2.8 & 0.8 & 23.1 & 26.0 \\
\hline 1557 & 11.5 & 19.2 & 11 & 294 & 0.2 & 3.0 & 1.0 & 22.0 & 25.1 \\
\hline 2057 & 16.4 & 27.4 & 14 & 340 & 0.3 & 4.0 & 1.6 & 26.4 & 30.7 \\
\hline 1861 & 8.5 & 14.2 & 12 & 339 & 0.0 & 2.5 & 0.7 & 22.1 & 24.6 \\
\hline 2762 & 18.7 & 31.2 & 16 & 341 & 0.6 & 4.4 & 2.0 & 30.8 & 35.8 \\
\hline 0163 & 28.9 & 48.2 & 14 & 297 & 0.9 & 5.1 & 2.7 & 26.7 & 32.7 \\
\hline 2563 & 39.3 & 65.7 & 16 & 303 & 1.5 & 5.8 & 3.9 & 33.1 & 40.4 \\
\hline 2965 & 11.1 & 18.6 & 14 & 321 & 0.0 & 3.3 & 1.0 & 24.2 & 27.4 \\
\hline 3367 & 29.9 & 49.9 & 16 & 340 & 2.4 & 5.0 & 3.1 & 30.3 & 37.7 \\
\hline 2168 & 11.8 & 19.7 & 11 & 296 & 0.1 & 3.1 & 1.0 & 21.9 & 25.1 \\
\hline 0571 & 7.5 & 12.6 & 16 & 292 & 0.3 & 2.5 & 0.7 & 23.4 & 26.2 \\
\hline 0676 & 16.0 & 26.8 & 16 & 300 & 0.2 & 4.1 & 1.6 & 29.7 & 34.0 \\
\hline 1977 & 12.8 & 21.4 & 12 & 344 & 0.3 & 3.3 & 1.2 & 23.0 & 26.6 \\
\hline 2379 & 7.2 & 12.1 & 9 & 349 & 0.2 & 1.8 & 0.6 & 19.5 & 21.5 \\
\hline 2187 & 17.4 & 29.0 & 14 & 306 & 0.2 & 4.2 & 1.7 & 26.3 & 30.6 \\
\hline 0188 & 21.7 & 36.2 & 16 & 344 & 1.4 & 4.5 & 2.3 & 30.7 & 36.6 \\
\hline 0289 & 14.1 & 23.6 & 12 & 339 & 0.5 & 3.5 & 1.3 & 22.8 & 26.8 \\
\hline 0190 & 16.4 & 27.4 & 14 & 341 & 0.7 & 3.9 & 1.7 & 26.4 & 31.0 \\
\hline 3190 & 14.8 & 24.7 & 12 & 342 & 0.2 & 3.7 & 1.3 & 22.8 & 26.6 \\
\hline 2691 & 19.3 & 32.3 & 14 & 324 & 0.0 & 4.5 & 1.8 & 26.0 & 30.4 \\
\hline 1592 & 15.4 & 25.8 & 14 & 340 & 0.6 & 3.8 & 1.6 & 26.2 & 30.7 \\
\hline 3192 & 17.1 & 28.5 & 14 & 339 & 0.7 & 4.0 & 1.7 & 26.3 & 31.0 \\
\hline 3594 & 9.8 & 16.4 & 11 & 331 & 0.0 & 2.7 & 0.9 & 21.9 & 24.6 \\
\hline 0597 & 26.2 & 43.8 & 14 & 345 & 1.0 & 4.9 & 2.5 & 26.1 & 32.0 \\
\hline 2997 & 33.8 & 56.4 & 16 & 325 & 1.6 & 5.4 & 3.4 & 31.3 & 38.4 \\
\hline 1367 & 35.7 & 59.7 & 16 & 341 & 2.3 & 5.4 & 3.6 & 32.0 & 39.7 \\
\hline 4367 & 29.9 & 49.9 & 16 & 343 & 1.9 & 5.1 & 3.0 & 30.2 & 37.1 \\
\hline 5163 & 33.8 & 56.4 & 16 & 337 & 1.1 & 5.5 & 3.3 & 31.2 & 37.8 \\
\hline 6163 & 19.3 & 32.3 & 16 & 329 & 0.2 & 4.6 & 2.0 & 30.8 & 35.5 \\
\hline
\end{tabular}


Table F49

Wave Parameters and Water Levels by Storm, Profile: Rota 49

\begin{tabular}{|c|c|c|c|c|c|c|c|c|c|}
\hline \multirow{2}{*}{ Storm } & \multicolumn{4}{|c|}{----Wave Parameters---- } & \multicolumn{5}{|c|}{ 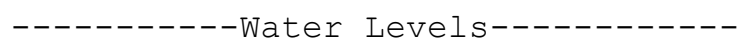 } \\
\hline & $\mathrm{HS}$ & H1 & $\mathrm{Tp}$ & Dir. & Surge & Ponding & Setup & Runup & Total \\
\hline No. & ft & ft & sec & deg az & ft & ft & ft & ft & ft \\
\hline 2348 & 13.8 & 23.0 & 11 & 353 & 0.8 & 3.3 & 1.1 & 7.6 & 11.7 \\
\hline 0150 & 6.9 & 11.5 & 11 & 3 & -0.1 & 2.0 & 0.5 & 4.8 & 6.7 \\
\hline 0853 & 19.0 & 31.8 & 14 & 3 & 0.3 & 4.3 & 1.7 & 12.6 & 17.2 \\
\hline 1953 & 12.2 & 20.3 & 11 & 355 & 0.3 & 3.1 & 1.0 & 7.3 & 10.7 \\
\hline 1557 & 10.5 & 17.5 & 11 & 2 & 0.5 & 2.8 & 0.9 & 6.9 & 10.1 \\
\hline 2057 & 22.3 & 37.3 & 14 & 359 & -0.3 & 4.8 & 1.8 & 12.8 & 17.4 \\
\hline 1861 & 11.5 & 19.2 & 12 & 354 & -0.1 & 3.2 & 0.9 & 7.6 & 10.6 \\
\hline 2762 & 25.9 & 43.3 & 16 & 359 & -0.5 & 5.3 & 2.2 & 16.0 & 20.9 \\
\hline 0163 & 27.5 & 46.0 & 14 & 316 & 0.0 & 5.2 & 2.2 & 13.2 & 18.5 \\
\hline 2563 & 39.0 & 65.2 & 16 & 334 & 0.8 & 5.9 & 3.4 & 17.2 & 23.9 \\
\hline 2965 & 15.1 & 25.2 & 12 & 332 & 0.0 & 3.8 & 1.2 & 8.9 & 12.6 \\
\hline 3367 & 37.4 & 62.5 & 16 & 355 & 2.1 & 5.5 & 3.4 & 17.5 & 25.2 \\
\hline 2168 & 10.5 & 17.5 & 12 & 357 & 0.2 & 2.9 & 0.8 & 7.3 & 10.4 \\
\hline 0571 & 12.2 & 20.3 & 12 & 356 & -0.1 & 3.3 & 0.9 & 7.9 & 11.0 \\
\hline 0676 & 13.5 & 22.5 & 16 & 313 & 0.2 & 3.8 & 1.2 & 11.6 & 15.6 \\
\hline 1977 & 16.0 & 26.8 & 12 & 357 & -0.1 & 3.9 & 1.3 & 9.0 & 12.9 \\
\hline 2379 & 8.9 & 14.8 & 10 & 3 & -0.1 & 2.4 & 0.6 & 5.4 & 7.8 \\
\hline 2187 & 23.3 & 38.9 & 14 & 338 & 0.1 & 4.8 & 2.0 & 12.7 & 17.7 \\
\hline 0188 & 30.8 & 51.5 & 16 & 355 & 0.8 & 5.4 & 2.8 & 15.8 & 22.0 \\
\hline 0289 & 18.7 & 31.2 & 12 & 346 & 0.3 & 4.1 & 1.5 & 9.1 & 13.5 \\
\hline 0190 & 24.9 & 41.6 & 14 & 344 & 0.4 & 4.9 & 2.1 & 12.6 & 18.0 \\
\hline 3190 & 14.1 & 23.6 & 14 & 0 & 0.0 & 3.8 & 1.2 & 10.6 & 14.4 \\
\hline 2691 & 18.7 & 31.2 & 14 & 346 & 0.0 & 4.4 & 1.6 & 12.4 & 16.8 \\
\hline 1592 & 20.0 & 33.4 & 14 & 355 & 0.0 & 4.5 & 1.7 & 12.7 & 17.2 \\
\hline 3192 & 22.3 & 37.3 & 14 & 356 & 0.2 & 4.7 & 1.9 & 12.8 & 17.7 \\
\hline 3594 & 10.5 & 17.5 & 11 & 342 & -0.1 & 2.9 & 0.8 & 6.7 & 9.5 \\
\hline 0597 & 31.2 & 52.1 & 14 & 356 & 0.3 & 5.4 & 2.5 & 14.1 & 19.9 \\
\hline 2997 & 40.7 & 67.9 & 14 & 338 & 1.6 & 5.7 & 3.5 & 15.9 & 23.2 \\
\hline 1367 & 40.0 & 66.8 & 16 & 353 & 2.2 & 5.6 & 3.7 & 18.0 & 25.8 \\
\hline 4367 & 36.4 & 60.8 & 16 & 356 & 1.1 & 5.7 & 3.2 & 16.9 & 23.7 \\
\hline 5163 & 32.5 & 54.2 & 16 & 351 & 1.7 & 5.3 & 3.0 & 16.3 & 23.3 \\
\hline 6163 & 18.7 & 31.2 & 16 & 342 & -0.1 & 4.5 & 1.7 & 14.5 & 19.0 \\
\hline
\end{tabular}


Table F53

Wave Parameters and Water Levels by Storm, Profile: Rota 53

\begin{tabular}{|c|c|c|c|c|c|c|c|c|c|}
\hline \multirow{3}{*}{$\begin{array}{c}\text { Storm } \\
\text { No. }\end{array}$} & \multicolumn{4}{|c|}{----Wave Parameters---- } & \multicolumn{5}{|c|}{----------- Water Levels ------------} \\
\hline & $\mathrm{Hs}$ & $\mathrm{H} 1$ & $\mathrm{Tp}$ & Dir. & Surge & Ponding & Setup & Runup & Total \\
\hline & ft & ft & sec & deg az & ft & ft & ft & ft & ft \\
\hline 2348 & 18.4 & 30.7 & 10 & 354 & 0.9 & 3.8 & 1.6 & 12.3 & 17.0 \\
\hline 0150 & 8.9 & 14.8 & 11 & 16 & 0.0 & 2.5 & 0.8 & 12.4 & 14.9 \\
\hline 0853 & 23.0 & 38.4 & 14 & 14 & 0.8 & 4.6 & 2.3 & 16.3 & 21.7 \\
\hline 1953 & 15.1 & 25.2 & 11 & 11 & 0.6 & 3.5 & 1.4 & 12.7 & 16.8 \\
\hline 1557 & 13.1 & 21.9 & 11 & 15 & 0.7 & 3.2 & 1.3 & 12.4 & 16.3 \\
\hline 2057 & 25.9 & 43.3 & 14 & 11 & 0.5 & 5.0 & 2.5 & 16.5 & 22.0 \\
\hline 1861 & 13.8 & 23.0 & 12 & 8 & 0.0 & 3.5 & 1.3 & 14.6 & 18.1 \\
\hline 2762 & 30.5 & 51.0 & 16 & 11 & 0.9 & 5.4 & 3.2 & 18.2 & 24.5 \\
\hline 0163 & 24.0 & 40.0 & 14 & 328 & 0.4 & 4.8 & 2.3 & 16.5 & 21.6 \\
\hline 2563 & 36.1 & 60.3 & 16 & 343 & 1.4 & 5.6 & 3.8 & 19.2 & 26.2 \\
\hline 2965 & 13.8 & 23.0 & 12 & 343 & 0.0 & 3.5 & 1.3 & 14.6 & 18.1 \\
\hline 3367 & 41.3 & 69.0 & 16 & 5 & 2.4 & 5.7 & 4.4 & 20.8 & 28.8 \\
\hline 2168 & 13.1 & 21.9 & 12 & 11 & 0.4 & 3.4 & 1.3 & 14.6 & 18.3 \\
\hline 0571 & 13.8 & 23.0 & 12 & 16 & 0.1 & 3.5 & 1.3 & 14.6 & 18.2 \\
\hline 0676 & 11.1 & 18.6 & 16 & 328 & 0.2 & 3.4 & 1.2 & 17.0 & 20.6 \\
\hline 1977 & 18.7 & 31.2 & 12 & 9 & 0.5 & 4.1 & 1.7 & 14.3 & 18.9 \\
\hline 2379 & 10.2 & 17.0 & 11 & 17 & 0.1 & 2.8 & 1.0 & 13.0 & 15.9 \\
\hline 2187 & 23.0 & 38.4 & 14 & 353 & 0.4 & 4.7 & 2.3 & 16.4 & 21.5 \\
\hline 0188 & 36.1 & 60.3 & 16 & 9 & 1.7 & 5.5 & 3.8 & 19.3 & 26.5 \\
\hline 0289 & 19.7 & 32.9 & 12 & 353 & 0.4 & 4.2 & 1.8 & 14.5 & 19.1 \\
\hline 0190 & 25.3 & 42.2 & 14 & 353 & 0.4 & 4.9 & 2.5 & 16.5 & 21.9 \\
\hline 3190 & 17.1 & 28.5 & 14 & 20 & 0.4 & 4.1 & 1.8 & 16.9 & 21.4 \\
\hline 2691 & 17.7 & 29.6 & 14 & 358 & 0.0 & 4.3 & 1.8 & 17.0 & 21.2 \\
\hline 1592 & 24.6 & 41.1 & 14 & 11 & 0.7 & 4.8 & 2.4 & 16.4 & 21.9 \\
\hline 3192 & 27.5 & 46.0 & 14 & 9 & 0.8 & 5.0 & 2.7 & 16.5 & 22.3 \\
\hline 3594 & 9.5 & 15.9 & 16 & 6 & -0.1 & 3.1 & 1.0 & 15.6 & 18.6 \\
\hline 0597 & 35.7 & 59.7 & 14 & 9 & 1.2 & 5.5 & 3.5 & 17.4 & 24.1 \\
\hline 2997 & 34.1 & 57.0 & 16 & 351 & 1.5 & 5.4 & 3.6 & 18.9 & 25.9 \\
\hline 1367 & 42.3 & 70.7 & 16 & 3 & 2.1 & 5.8 & 4.4 & 21.0 & 28.9 \\
\hline 4367 & 40.7 & 67.9 & 16 & 7 & 2.0 & 5.7 & 4.3 & 20.6 & 28.4 \\
\hline 5163 & 34.8 & 58.1 & 16 & 1 & 1.7 & 5.4 & 3.7 & 18.9 & 26.1 \\
\hline 6163 & 17.1 & 28.5 & 16 & 352 & 0.1 & 4.3 & 1.9 & 18.1 & 22.5 \\
\hline
\end{tabular}


Table F57

Wave Parameters and Water Levels by Storm, Profile: Rota 57

\begin{tabular}{|c|c|c|c|c|c|c|c|c|c|}
\hline \multirow{3}{*}{$\begin{array}{c}\text { Storm } \\
\text { No. }\end{array}$} & \multicolumn{4}{|c|}{----Wave Parameters---- } & \multicolumn{5}{|c|}{----------- Water Levels ------------} \\
\hline & $\mathrm{Hs}$ & $\mathrm{H} 1$ & $\mathrm{Tp}$ & Dir. & Surge & Ponding & Setup & Runup & Total \\
\hline & ft & ft & sec & deg az & ft & ft & ft & ft & ft \\
\hline 2348 & 18.4 & 30.7 & 10 & 354 & 1.0 & 3.8 & 1.7 & 11.9 & 16.6 \\
\hline 0150 & 8.9 & 14.8 & 11 & 16 & 0.0 & 2.5 & 0.9 & 12.4 & 15.0 \\
\hline 0853 & 23.0 & 38.4 & 14 & 14 & 0.9 & 4.6 & 2.4 & 14.4 & 19.9 \\
\hline 1953 & 15.1 & 25.2 & 11 & 11 & 0.6 & 3.5 & 1.5 & 12.3 & 16.4 \\
\hline 1557 & 13.1 & 21.9 & 11 & 15 & 0.8 & 3.2 & 1.3 & 12.1 & 16.0 \\
\hline 2057 & 25.9 & 43.3 & 14 & 11 & 0.6 & 4.9 & 2.7 & 14.9 & 20.4 \\
\hline 1861 & 13.1 & 21.9 & 12 & 8 & 0.1 & 3.4 & 1.4 & 13.5 & 17.0 \\
\hline 2762 & 30.5 & 51.0 & 16 & 11 & 1.1 & 5.3 & 3.3 & 17.9 & 24.3 \\
\hline 0163 & 24.0 & 40.0 & 14 & 328 & 0.4 & 4.8 & 2.5 & 14.6 & 19.8 \\
\hline 2563 & 36.1 & 60.3 & 16 & 343 & 1.5 & 5.6 & 3.9 & 20.3 & 27.4 \\
\hline 2965 & 9.8 & 16.4 & 14 & 344 & 0.0 & 3.0 & 1.0 & 14.3 & 17.3 \\
\hline 3367 & 41.3 & 69.0 & 16 & 5 & 2.4 & 5.6 & 4.5 & 22.1 & 30.2 \\
\hline 2168 & 13.1 & 21.9 & 12 & 11 & 0.4 & 3.4 & 1.4 & 13.4 & 17.1 \\
\hline 0571 & 13.1 & 21.9 & 12 & 17 & 0.1 & 3.4 & 1.4 & 13.5 & 17.0 \\
\hline 0676 & 11.1 & 18.6 & 16 & 328 & 0.2 & 3.4 & 1.3 & 15.2 & 18.8 \\
\hline 1977 & 18.7 & 31.2 & 12 & 9 & 0.6 & 4.1 & 1.9 & 13.1 & 17.8 \\
\hline 2379 & 10.2 & 17.0 & 11 & 17 & 0.2 & 2.8 & 1.0 & 12.8 & 15.7 \\
\hline 2187 & 23.0 & 38.4 & 14 & 353 & 0.5 & 4.7 & 2.4 & 14.5 & 19.6 \\
\hline 0188 & 36.1 & 60.3 & 16 & 9 & 1.8 & 5.5 & 4.0 & 20.4 & 27.7 \\
\hline 0289 & 19.7 & 32.9 & 12 & 353 & 0.4 & 4.2 & 1.9 & 13.2 & 17.9 \\
\hline 0190 & 25.3 & 42.2 & 14 & 353 & 0.5 & 4.9 & 2.6 & 14.7 & 20.1 \\
\hline 3190 & 16.0 & 26.8 & 14 & 21 & 0.4 & 4.0 & 1.8 & 14.8 & 19.1 \\
\hline 2691 & 17.4 & 29.0 & 14 & 353 & 0.0 & 4.2 & 1.9 & 14.8 & 19.0 \\
\hline 1592 & 24.6 & 41.1 & 14 & 11 & 0.8 & 4.8 & 2.6 & 14.6 & 20.2 \\
\hline 3192 & 27.5 & 46.0 & 14 & 9 & 0.9 & 5.0 & 2.9 & 15.3 & 21.2 \\
\hline 3594 & 9.5 & 15.9 & 16 & 6 & -0.1 & 3.1 & 1.0 & 14.7 & 17.7 \\
\hline 0597 & 35.7 & 59.7 & 14 & 9 & 1.4 & 5.4 & 3.7 & 17.7 & 24.5 \\
\hline 2997 & 34.1 & 57.0 & 16 & 351 & 1.7 & 5.4 & 3.8 & 19.6 & 26.7 \\
\hline 1367 & 42.3 & 70.7 & 16 & 3 & 2.2 & 5.8 & 4.6 & 22.3 & 30.3 \\
\hline 4367 & 40.7 & 67.9 & 16 & 7 & 2.2 & 5.7 & 4.4 & 21.9 & 29.8 \\
\hline 5163 & 34.8 & 58.1 & 16 & 1 & 1.8 & 5.4 & 3.8 & 19.9 & 27.1 \\
\hline 6163 & 17.1 & 28.5 & 16 & 352 & 0.1 & 4.3 & 2.0 & 16.7 & 21.1 \\
\hline
\end{tabular}


Table F61

Wave Parameters and Water Levels by Storm, Profile: Rota 61

\begin{tabular}{|c|c|c|c|c|c|c|c|c|c|}
\hline \multirow{3}{*}{$\begin{array}{c}\text { Storm } \\
\text { No. }\end{array}$} & \multicolumn{4}{|c|}{----Wave Parameters---- } & \multicolumn{5}{|c|}{----------- Water Levels ------------} \\
\hline & $\mathrm{Hs}$ & $\mathrm{H} 1$ & $\mathrm{Tp}$ & Dir. & Surge & Ponding & Setup & Runup & Total \\
\hline & ft & ft & sec & deg az & ft & ft & ft & ft & ft \\
\hline 2348 & 14.6 & 24.4 & 11 & 2 & 0.9 & 3.4 & 1.1 & 10.2 & 14.5 \\
\hline 0150 & 8.4 & 14.0 & 11 & 16 & 0.0 & 2.4 & 0.5 & 7.8 & 10.2 \\
\hline 0853 & 22.2 & 37.0 & 14 & 14 & 0.9 & 4.5 & 1.8 & 13.2 & 18.6 \\
\hline 1953 & 14.8 & 24.7 & 11 & 11 & 0.6 & 3.5 & 1.0 & 10.2 & 14.3 \\
\hline 1557 & 12.6 & 21.1 & 11 & 15 & 0.8 & 3.1 & 0.9 & 10.0 & 13.9 \\
\hline 2057 & 24.4 & 40.8 & 14 & 11 & 0.6 & 4.8 & 1.9 & 13.2 & 18.6 \\
\hline 1861 & 13.3 & 22.2 & 12 & 8 & 0.1 & 3.5 & 0.9 & 10.6 & 14.1 \\
\hline 2762 & 29.5 & 49.3 & 16 & 11 & 1.1 & 5.2 & 2.5 & 15.9 & 22.3 \\
\hline 0163 & 22.8 & 38.1 & 14 & 321 & 0.7 & 4.6 & 1.8 & 13.2 & 18.6 \\
\hline 2563 & 36.8 & 61.4 & 16 & 343 & 1.6 & 5.6 & 3.0 & 16.8 & 24.0 \\
\hline 2965 & 14.0 & 23.3 & 12 & 343 & 0.0 & 3.6 & 1.0 & 10.8 & 14.4 \\
\hline 3367 & 40.5 & 67.7 & 16 & 5 & 2.5 & 5.6 & 3.4 & 17.8 & 25.9 \\
\hline 2168 & 12.5 & 20.8 & 12 & 11 & 0.4 & 3.2 & 0.9 & 10.5 & 14.1 \\
\hline 0571 & 15.3 & 25.5 & 12 & 15 & 0.2 & 3.7 & 1.1 & 11.1 & 15.0 \\
\hline 0676 & 17.1 & 28.5 & 12 & 14 & 0.9 & 3.8 & 1.3 & 11.3 & 16.0 \\
\hline 1977 & 18.2 & 30.4 & 12 & 9 & 0.6 & 4.0 & 1.3 & 11.4 & 16.0 \\
\hline 2379 & 9.7 & 16.2 & 11 & 17 & 0.2 & 2.7 & 0.6 & 8.8 & 11.6 \\
\hline 2187 & 22.0 & 36.7 & 14 & 347 & 0.5 & 4.6 & 1.7 & 13.4 & 18.5 \\
\hline 0188 & 35.3 & 58.9 & 16 & 9 & 1.9 & 5.4 & 2.9 & 16.6 & 23.9 \\
\hline 0289 & 18.6 & 31.0 & 12 & 1 & 0.6 & 4.1 & 1.4 & 11.4 & 16.0 \\
\hline 0190 & 23.6 & 39.4 & 14 & 1 & 0.6 & 4.7 & 1.8 & 13.2 & 18.6 \\
\hline 3190 & 17.9 & 29.9 & 14 & 18 & 0.5 & 4.2 & 1.4 & 13.1 & 17.7 \\
\hline 2691 & 17.9 & 29.9 & 14 & 346 & 0.0 & 4.3 & 1.3 & 13.0 & 17.2 \\
\hline 1592 & 23.5 & 39.2 & 14 & 12 & 0.9 & 4.7 & 1.9 & 13.1 & 18.7 \\
\hline 3192 & 24.8 & 41.4 & 14 & 8 & 0.9 & 4.8 & 1.9 & 13.0 & 18.6 \\
\hline 3594 & 9.3 & 15.6 & 16 & 6 & -0.1 & 3.0 & 0.6 & 11.4 & 14.3 \\
\hline 0597 & 35.1 & 58.6 & 14 & 9 & 1.5 & 5.4 & 2.7 & 14.1 & 21.0 \\
\hline 2997 & 34.8 & 58.1 & 16 & 351 & 1.8 & 5.4 & 2.9 & 16.4 & 23.6 \\
\hline 1367 & 42.0 & 70.1 & 16 & 3 & 2.3 & 5.7 & 3.5 & 17.9 & 25.9 \\
\hline 4367 & 39.7 & 66.3 & 16 & 7 & 2.3 & 5.6 & 3.3 & 17.6 & 25.5 \\
\hline 5163 & 34.3 & 57.3 & 16 & 1 & 1.8 & 5.4 & 2.9 & 16.3 & 23.5 \\
\hline 6163 & 17.1 & 28.5 & 16 & 352 & 0.1 & 4.3 & 1.3 & 13.8 & 18.1 \\
\hline
\end{tabular}


Table F65

Wave Parameters and Water Levels by Storm, Profile: Rota 65

\begin{tabular}{|c|c|c|c|c|c|c|c|c|c|}
\hline \multirow{2}{*}{ Storm } & \multicolumn{4}{|c|}{--Wave Parameters---- } & \multicolumn{5}{|c|}{ 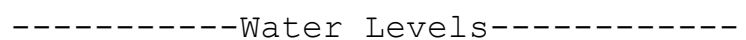 } \\
\hline & $\mathrm{Hs}$ & H1 & $\mathrm{Tp}$ & Dir. & Surge & Ponding & Setup & Runup & Total \\
\hline No. & ft & ft & sec & deg az & ft & ft & ft & ft & ft \\
\hline 2348 & 18.0 & 30.1 & 10 & 351 & 1.0 & 3.7 & 1.4 & 5.6 & 10.3 \\
\hline 0150 & 7.8 & 13.1 & 11 & 11 & 0.0 & 2.2 & 0.6 & 2.6 & 4.9 \\
\hline 0853 & 21.3 & 35.6 & 14 & 8 & 0.8 & 4.5 & 1.9 & 11.2 & 16.4 \\
\hline 1953 & 14.4 & 24.1 & 11 & 6 & 0.6 & 3.4 & 1.2 & 5.6 & 9.6 \\
\hline 1557 & 12.2 & 20.3 & 11 & 9 & 0.8 & 3.0 & 1.0 & 5.1 & 8.9 \\
\hline 2057 & 23.6 & 39.4 & 14 & 5 & 0.6 & 4.8 & 2.1 & 11.1 & 16.4 \\
\hline 1861 & 12.8 & 21.4 & 12 & 2 & 0.1 & 3.4 & 1.1 & 5.7 & 9.1 \\
\hline 2762 & 28.6 & 47.7 & 16 & 6 & 1.0 & 5.2 & 2.7 & 12.2 & 18.5 \\
\hline 0163 & 20.7 & 34.5 & 14 & 311 & 0.9 & 4.4 & 1.9 & 11.2 & 16.5 \\
\hline 2563 & 37.4 & 62.5 & 16 & 339 & 1.6 & 5.6 & 3.5 & 13.8 & 21.0 \\
\hline 2965 & 14.1 & 23.6 & 12 & 337 & 0.0 & 3.6 & 1.2 & 6.3 & 9.9 \\
\hline 3367 & 39.7 & 66.3 & 16 & 0 & 2.5 & 5.6 & 3.8 & 14.5 & 22.5 \\
\hline 2168 & 11.8 & 19.7 & 12 & 4 & 0.4 & 3.1 & 1.0 & 5.5 & 9.0 \\
\hline 0571 & 14.8 & 24.7 & 12 & 9 & 0.1 & 3.7 & 1.2 & 6.6 & 10.4 \\
\hline 0676 & 16.4 & 27.4 & 12 & 8 & 0.9 & 3.7 & 1.4 & 7.3 & 11.9 \\
\hline 1977 & 17.7 & 29.6 & 12 & 3 & 0.6 & 4.0 & 1.5 & 7.2 & 11.8 \\
\hline 2379 & 10.2 & 17.0 & 10 & 11 & 0.2 & 2.7 & 0.8 & 3.4 & 6.3 \\
\hline 2187 & 22.3 & 37.3 & 14 & 343 & 0.5 & 4.7 & 2.0 & 11.1 & 16.2 \\
\hline 0188 & 34.4 & 57.5 & 16 & 3 & 1.8 & 5.4 & 3.2 & 13.4 & 20.6 \\
\hline 0289 & 19.0 & 31.8 & 12 & 352 & 0.6 & 4.1 & 1.6 & 7.6 & 12.2 \\
\hline 0190 & 24.0 & 40.0 & 14 & 349 & 0.4 & 4.8 & 2.1 & 11.1 & 16.4 \\
\hline 3190 & 17.1 & 28.5 & 14 & 12 & 0.4 & 4.1 & 1.6 & 10.3 & 14.8 \\
\hline 2691 & 18.0 & 30.1 & 14 & 341 & 0.0 & 4.3 & 1.6 & 10.3 & 14.6 \\
\hline 1592 & 22.0 & 36.7 & 14 & 9 & 0.8 & 4.6 & 2.0 & 11.1 & 16.4 \\
\hline 3192 & 25.9 & 43.3 & 14 & 4 & 0.9 & 4.9 & 2.3 & 10.8 & 16.5 \\
\hline 3594 & 9.2 & 15.3 & 16 & 358 & -0.1 & 3.0 & 0.8 & 5.2 & 8.1 \\
\hline 0597 & 34.4 & 57.5 & 14 & 5 & 1.4 & 5.4 & 3.0 & 11.6 & 18.4 \\
\hline 2997 & 35.4 & 59.2 & 16 & 347 & 1.8 & 5.5 & 3.3 & 13.6 & 20.8 \\
\hline 1367 & 41.7 & 69.6 & 16 & 358 & 2.3 & 5.7 & 3.9 & 15.0 & 23.0 \\
\hline 4367 & 38.7 & 64.7 & 16 & 2 & 2.2 & 5.6 & 3.7 & 14.1 & 21.9 \\
\hline 5163 & 33.8 & 56.4 & 16 & 356 & 1.8 & 5.4 & 3.2 & 13.3 & 20.5 \\
\hline 6163 & 17.1 & 28.5 & 16 & 346 & 0.1 & 4.3 & 1.6 & 12.1 & 16.5 \\
\hline
\end{tabular}


Table F69

Wave Parameters and Water Levels by Storm, Profile: Rota 69

\begin{tabular}{|c|c|c|c|c|c|c|c|c|c|}
\hline \multirow{3}{*}{$\begin{array}{c}\text { Storm } \\
\text { No. }\end{array}$} & \multicolumn{4}{|c|}{----Wave Parameters---- } & \multicolumn{5}{|c|}{----------- Water Levels ------------} \\
\hline & $\mathrm{Hs}$ & $\mathrm{H} 1$ & $\mathrm{Tp}$ & Dir. & Surge & Ponding & Setup & Runup & Total \\
\hline & ft & ft & sec & $\operatorname{deg} a z$ & ft & ft & ft & ft & ft \\
\hline 2348 & 14.4 & 24.1 & 11 & 357 & 0.9 & 3.4 & 0.9 & 8.4 & 12.6 \\
\hline 0150 & 7.8 & 13.1 & 11 & 11 & 0.0 & 2.2 & 0.4 & 4.8 & 7.1 \\
\hline 0853 & 21.3 & 35.6 & 14 & 8 & 0.8 & 4.5 & 1.5 & 10.8 & 16.1 \\
\hline 1953 & 14.4 & 24.1 & 11 & 6 & 0.5 & 3.4 & 0.9 & 8.2 & 12.2 \\
\hline 1557 & 12.2 & 20.3 & 11 & 9 & 0.7 & 3.0 & 0.8 & 7.4 & 11.1 \\
\hline 2057 & 24.3 & 40.5 & 14 & 5 & 0.4 & 4.8 & 1.6 & 11.3 & 16.5 \\
\hline 1861 & 12.8 & 21.4 & 12 & 2 & 0.0 & 3.4 & 0.8 & 7.8 & 11.2 \\
\hline 2762 & 28.6 & 47.7 & 16 & 6 & 0.9 & 5.2 & 2.1 & 14.5 & 20.6 \\
\hline 0163 & 24.9 & 41.6 & 14 & 319 & 0.6 & 4.9 & 1.7 & 11.4 & 16.8 \\
\hline 2563 & 37.4 & 62.5 & 16 & 339 & 1.6 & 5.6 & 2.8 & 14.8 & 22.0 \\
\hline 2965 & 14.1 & 23.6 & 12 & 337 & 0.1 & 3.6 & 0.8 & 8.6 & 12.2 \\
\hline 3367 & 39.7 & 66.3 & 16 & 0 & 2.4 & 5.6 & 3.0 & 15.4 & 23.4 \\
\hline 2168 & 11.8 & 19.7 & 12 & 4 & 0.3 & 3.1 & 0.7 & 7.6 & 11.1 \\
\hline 0571 & 14.8 & 24.7 & 12 & 9 & 0.1 & 3.7 & 0.9 & 8.8 & 12.6 \\
\hline 0676 & 16.7 & 27.9 & 12 & 7 & 0.7 & 3.8 & 1.1 & 9.7 & 14.2 \\
\hline 1977 & 17.7 & 29.6 & 12 & 3 & 0.4 & 4.0 & 1.1 & 9.9 & 14.3 \\
\hline 2379 & 10.2 & 17.0 & 10 & 11 & 0.1 & 2.7 & 0.6 & 5.3 & 8.1 \\
\hline 2187 & 22.3 & 37.3 & 14 & 343 & 0.5 & 4.7 & 1.5 & 10.9 & 16.0 \\
\hline 0188 & 34.4 & 57.5 & 16 & 3 & 1.7 & 5.4 & 2.6 & 14.6 & 21.7 \\
\hline 0289 & 19.0 & 31.8 & 12 & 352 & 0.5 & 4.1 & 1.2 & 9.8 & 14.5 \\
\hline 0190 & 25.3 & 42.2 & 14 & 349 & 0.5 & 4.9 & 1.7 & 11.4 & 16.8 \\
\hline 3190 & 17.1 & 28.5 & 14 & 12 & 0.4 & 4.1 & 1.1 & 10.3 & 14.8 \\
\hline 2691 & 18.0 & 30.1 & 14 & 341 & 0.0 & 4.3 & 1.1 & 10.4 & 14.7 \\
\hline 1592 & 23.0 & 38.4 & 14 & 5 & 0.7 & 4.7 & 1.6 & 11.1 & 16.5 \\
\hline 3192 & 25.9 & 43.3 & 14 & 4 & 0.8 & 4.9 & 1.8 & 11.5 & 17.2 \\
\hline 3594 & 9.2 & 15.3 & 16 & 358 & -0.1 & 3.0 & 0.6 & 9.3 & 12.2 \\
\hline 0597 & 34.4 & 57.5 & 14 & 5 & 1.2 & 5.4 & 2.3 & 12.4 & 19.0 \\
\hline 2997 & 35.4 & 59.2 & 16 & 347 & 1.8 & 5.5 & 2.7 & 14.4 & 21.7 \\
\hline 1367 & 41.7 & 69.6 & 16 & 358 & 2.3 & 5.7 & 3.1 & 15.7 & 23.7 \\
\hline 4367 & 38.7 & 64.7 & 16 & 2 & 2.0 & 5.6 & 2.9 & 15.2 & 22.8 \\
\hline 5163 & 33.8 & 56.4 & 16 & 356 & 1.9 & 5.3 & 2.6 & 14.6 & 21.8 \\
\hline 6163 & 18.7 & 31.2 & 14 & 314 & 0.6 & 4.2 & 1.3 & 10.5 & 15.4 \\
\hline
\end{tabular}


Table F73

Wave Parameters and Water Levels by Storm, Profile: Rota 73

\begin{tabular}{|c|c|c|c|c|c|c|c|c|c|}
\hline \multirow{3}{*}{$\begin{array}{c}\text { Storm } \\
\text { No. }\end{array}$} & \multicolumn{4}{|c|}{----Wave Parameters---- } & \multicolumn{5}{|c|}{----------- Water Levels------------ } \\
\hline & $\mathrm{Hs}$ & $\mathrm{H} 1$ & $\mathrm{Tp}$ & Dir. & Surge & Ponding & Setup & Runup & Total \\
\hline & ft & ft & sec & deg az & ft & ft & ft & ft & ft \\
\hline 2348 & 14.4 & 24.1 & 11 & 357 & 0.9 & 3.4 & 1.0 & 6.6 & 10.8 \\
\hline 0150 & 7.8 & 13.1 & 11 & 11 & -0.1 & 2.3 & 0.4 & 6.2 & 8.4 \\
\hline 0853 & 21.3 & 35.6 & 14 & 8 & 0.5 & 4.5 & 1.5 & 7.4 & 12.4 \\
\hline 1953 & 14.4 & 24.1 & 11 & 6 & 0.4 & 3.5 & 0.9 & 6.5 & 10.4 \\
\hline 1557 & 12.2 & 20.3 & 11 & 9 & 0.6 & 3.1 & 0.8 & 6.3 & 9.9 \\
\hline 2057 & 24.3 & 40.5 & 14 & 5 & 0.2 & 4.9 & 1.6 & 7.4 & 12.5 \\
\hline 1861 & 12.8 & 21.4 & 12 & 2 & -0.1 & 3.4 & 0.8 & 6.6 & 9.9 \\
\hline 2762 & 28.6 & 47.7 & 16 & 6 & 0.4 & 5.3 & 2.1 & 7.0 & 12.8 \\
\hline 0163 & 25.3 & 42.2 & 14 & 323 & 0.3 & 4.9 & 1.7 & 7.2 & 12.5 \\
\hline 2563 & 37.7 & 62.9 & 16 & 339 & 1.2 & 5.7 & 2.8 & 6.3 & 13.3 \\
\hline 2965 & 14.1 & 23.6 & 12 & 337 & 0.0 & 3.6 & 0.9 & 6.8 & 10.4 \\
\hline 3367 & 39.7 & 66.3 & 16 & 0 & 2.3 & 5.6 & 3.0 & 6.4 & 14.2 \\
\hline 2168 & 11.8 & 19.7 & 12 & 4 & 0.2 & 3.2 & 0.7 & 6.4 & 9.9 \\
\hline 0571 & 14.8 & 24.7 & 12 & 9 & 0.0 & 3.7 & 0.9 & 7.0 & 10.7 \\
\hline 0676 & 16.7 & 27.9 & 12 & 7 & 0.5 & 3.9 & 1.1 & 7.4 & 11.8 \\
\hline 1977 & 17.7 & 29.6 & 12 & 3 & 0.3 & 4.0 & 1.1 & 7.5 & 11.8 \\
\hline 2379 & 10.2 & 17.0 & 10 & 11 & 0.1 & 2.7 & 0.6 & 5.9 & 8.7 \\
\hline 2187 & 22.6 & 37.7 & 14 & 343 & 0.3 & 4.7 & 1.5 & 7.4 & 12.4 \\
\hline 0188 & 35.1 & 58.6 & 14 & 3 & 1.3 & 5.4 & 2.4 & 6.5 & 13.3 \\
\hline 0289 & 19.0 & 31.8 & 12 & 352 & 0.5 & 4.1 & 1.2 & 7.4 & 12.1 \\
\hline 0190 & 25.3 & 42.2 & 14 & 349 & 0.4 & 4.9 & 1.8 & 7.2 & 12.5 \\
\hline 3190 & 17.1 & 28.5 & 14 & 12 & 0.2 & 4.1 & 1.1 & 7.8 & 12.2 \\
\hline 2691 & 18.3 & 30.6 & 14 & 341 & 0.0 & 4.3 & 1.2 & 7.9 & 12.2 \\
\hline 1592 & 23.0 & 38.4 & 14 & 5 & 0.4 & 4.7 & 1.6 & 7.3 & 12.4 \\
\hline 3192 & 25.9 & 43.3 & 14 & 4 & 0.5 & 5.0 & 1.8 & 7.1 & 12.6 \\
\hline 3594 & 9.2 & 15.3 & 16 & 358 & -0.1 & 3.0 & 0.6 & 7.3 & 10.2 \\
\hline 0597 & 34.4 & 57.5 & 14 & 3 & 0.9 & 5.5 & 2.3 & 6.6 & 12.9 \\
\hline 2997 & 40.7 & 67.9 & 14 & 341 & 1.7 & 5.6 & 2.9 & 5.8 & 13.2 \\
\hline 1367 & 41.7 & 69.6 & 16 & 358 & 2.2 & 5.7 & 3.2 & 6.5 & 14.4 \\
\hline 4367 & 38.7 & 64.7 & 16 & 2 & 1.7 & 5.7 & 2.9 & 6.3 & 13.7 \\
\hline 5163 & 33.8 & 56.4 & 16 & 356 & 1.8 & 5.4 & 2.7 & 6.0 & 13.2 \\
\hline 6163 & 18.9 & 31.6 & 14 & 317 & 0.4 & 4.3 & 1.3 & 7.6 & 12.3 \\
\hline
\end{tabular}


Table F77

Wave Parameters and Water Levels by Storm, Profile: Rota 77

\begin{tabular}{|c|c|c|c|c|c|c|c|c|c|}
\hline \multirow{3}{*}{$\begin{array}{c}\text { Storm } \\
\text { No. }\end{array}$} & \multicolumn{4}{|c|}{----Wave Parameters---- } & \multicolumn{5}{|c|}{----------- Water Levels ------------} \\
\hline & $\mathrm{Hs}$ & $\mathrm{H} 1$ & $\mathrm{Tp}$ & Dir. & Surge & Ponding & Setup & Runup & Total \\
\hline & ft & ft & sec & deg az & ft & ft & ft & ft & ft \\
\hline 2348 & 17.8 & 29.8 & 10 & 351 & 1.0 & 3.7 & 1.1 & 5.3 & 10.0 \\
\hline 0150 & 7.2 & 12.0 & 11 & 10 & 0.0 & 2.0 & 0.4 & 4.2 & 6.2 \\
\hline 0853 & 19.7 & 32.9 & 14 & 8 & 0.8 & 4.3 & 1.5 & 7.4 & 12.4 \\
\hline 1953 & 12.8 & 21.4 & 11 & 6 & 0.6 & 3.2 & 0.9 & 5.7 & 9.4 \\
\hline 1557 & 11.0 & 18.4 & 11 & 9 & 0.7 & 2.8 & 0.7 & 5.5 & 9.0 \\
\hline 2057 & 22.9 & 38.2 & 14 & 5 & 0.5 & 4.7 & 1.6 & 7.8 & 12.9 \\
\hline 1861 & 11.9 & 19.8 & 12 & 2 & 0.0 & 3.2 & 0.7 & 5.8 & 9.1 \\
\hline 2762 & 26.7 & 44.6 & 16 & 6 & 0.9 & 5.1 & 2.1 & 9.5 & 15.5 \\
\hline 0163 & 25.8 & 43.1 & 14 & 315 & 0.7 & 4.9 & 1.9 & 8.1 & 13.7 \\
\hline 2563 & 38.6 & 64.5 & 16 & 339 & 1.5 & 5.7 & 3.0 & 11.6 & 18.9 \\
\hline 2965 & 14.8 & 24.7 & 12 & 337 & 0.1 & 3.7 & 0.9 & 6.2 & 9.9 \\
\hline 3367 & 38.1 & 63.6 & 16 & 0 & 2.5 & 5.5 & 3.0 & 12.0 & 19.9 \\
\hline 2168 & 10.9 & 18.2 & 12 & 4 & 0.3 & 3.0 & 0.7 & 5.7 & 9.0 \\
\hline 0571 & 12.9 & 21.6 & 12 & 9 & 0.1 & 3.4 & 0.8 & 6.0 & 9.5 \\
\hline 0676 & 15.3 & 25.6 & 12 & 7 & 0.7 & 3.6 & 1.1 & 6.2 & 10.6 \\
\hline 1977 & 16.6 & 27.7 & 12 & 3 & 0.5 & 3.8 & 1.1 & 6.4 & 10.7 \\
\hline 2379 & 9.2 & 15.3 & 10 & 10 & 0.2 & 2.4 & 0.6 & 4.8 & 7.4 \\
\hline 2187 & 23.1 & 38.6 & 14 & 343 & 0.4 & 4.7 & 1.6 & 7.8 & 13.0 \\
\hline 0188 & 31.9 & 53.3 & 16 & 3 & 1.8 & 5.2 & 2.6 & 10.6 & 17.6 \\
\hline 0289 & 18.6 & 31.0 & 12 & 352 & 0.6 & 4.1 & 1.3 & 6.5 & 11.1 \\
\hline 0190 & 25.0 & 41.8 & 14 & 349 & 0.5 & 4.9 & 1.8 & 8.0 & 13.4 \\
\hline 3190 & 19.7 & 32.9 & 12 & 4 & 0.3 & 4.3 & 1.3 & 6.5 & 11.1 \\
\hline 2691 & 18.6 & 31.1 & 14 & 341 & 0.0 & 4.4 & 1.3 & 7.1 & 11.5 \\
\hline 1592 & 20.9 & 34.9 & 14 & 5 & 0.7 & 4.4 & 1.5 & 7.6 & 12.7 \\
\hline 3192 & 24.6 & 41.0 & 14 & 4 & 0.8 & 4.8 & 1.8 & 8.0 & 13.6 \\
\hline 3594 & 10.5 & 17.5 & 11 & 348 & 0.0 & 2.9 & 0.6 & 5.4 & 8.3 \\
\hline 0597 & 32.2 & 53.7 & 14 & 3 & 1.2 & 5.2 & 2.3 & 8.7 & 15.2 \\
\hline 2997 & 40.7 & 67.9 & 14 & 341 & 2.2 & 5.5 & 3.0 & 10.1 & 17.8 \\
\hline 1367 & 40.5 & 67.7 & 16 & 358 & 2.3 & 5.6 & 3.2 & 12.4 & 20.4 \\
\hline 4367 & 37.1 & 62.0 & 16 & 2 & 2.1 & 5.5 & 2.9 & 11.6 & 19.2 \\
\hline 5163 & 32.9 & 54.9 & 16 & 356 & 2.0 & 5.3 & 2.7 & 10.7 & 17.9 \\
\hline 6163 & 21.3 & 35.6 & 14 & 313 & 0.6 & 4.5 & 1.6 & 7.6 & 12.7 \\
\hline
\end{tabular}


Table F81

Wave Parameters and Water Levels by Storm, Profile: Rota 81

\begin{tabular}{|c|c|c|c|c|c|c|c|c|c|}
\hline \multirow{3}{*}{$\begin{array}{c}\text { Storm } \\
\text { No. }\end{array}$} & \multicolumn{4}{|c|}{----Wave Parameters---- } & \multicolumn{5}{|c|}{----------- Water Levels------------ } \\
\hline & $\mathrm{Hs}$ & $\mathrm{H} 1$ & $\mathrm{Tp}$ & Dir. & Surge & Ponding & Setup & Runup & Total \\
\hline & ft & ft & sec & deg az & ft & ft & ft & ft & ft \\
\hline 2348 & 13.8 & 23.0 & 11 & 353 & 0.9 & 3.2 & 1.2 & 9.2 & 13.4 \\
\hline 0150 & 6.9 & 11.5 & 11 & 3 & 0.0 & 2.0 & 0.5 & 7.6 & 9.6 \\
\hline 0853 & 19.0 & 31.8 & 14 & 1 & 0.8 & 4.2 & 1.7 & 11.6 & 16.6 \\
\hline 1953 & 12.2 & 20.3 & 11 & 355 & 0.6 & 3.0 & 1.0 & 9.4 & 13.1 \\
\hline 1557 & 10.5 & 17.5 & 11 & 2 & 0.7 & 2.7 & 0.9 & 9.3 & 12.7 \\
\hline 2057 & 22.3 & 37.3 & 14 & 359 & 0.5 & 4.6 & 2.0 & 11.6 & 16.7 \\
\hline 1861 & 11.5 & 19.2 & 12 & 354 & 0.0 & 3.2 & 0.9 & 9.9 & 13.1 \\
\hline 2762 & 25.9 & 43.3 & 16 & 359 & 1.1 & 5.0 & 2.5 & 14.1 & 20.1 \\
\hline 0163 & 27.5 & 46.0 & 14 & 316 & 0.6 & 5.1 & 2.3 & 12.2 & 17.8 \\
\hline 2563 & 39.0 & 65.2 & 16 & 334 & 1.7 & 5.7 & 3.6 & 15.9 & 23.4 \\
\hline 2965 & 15.1 & 25.2 & 12 & 332 & 0.1 & 3.7 & 1.2 & 10.2 & 14.0 \\
\hline 3367 & 37.4 & 62.5 & 16 & 355 & 2.5 & 5.4 & 3.5 & 15.9 & 23.8 \\
\hline 2168 & 10.5 & 17.5 & 12 & 357 & 0.4 & 2.9 & 0.9 & 9.7 & 12.9 \\
\hline 0571 & 12.2 & 20.3 & 12 & 356 & 0.1 & 3.2 & 1.0 & 10.0 & 13.4 \\
\hline 0676 & 13.5 & 22.5 & 16 & 313 & 0.2 & 3.8 & 1.2 & 11.8 & 15.7 \\
\hline 1977 & 16.0 & 26.8 & 12 & 357 & 0.5 & 3.8 & 1.4 & 10.0 & 14.3 \\
\hline 2379 & 8.9 & 14.8 & 10 & 3 & 0.2 & 2.3 & 0.7 & 8.2 & 10.8 \\
\hline 2187 & 23.3 & 38.9 & 14 & 338 & 0.5 & 4.7 & 2.0 & 11.5 & 16.7 \\
\hline 0188 & 30.8 & 51.5 & 16 & 355 & 1.9 & 5.2 & 2.9 & 14.6 & 21.7 \\
\hline 0289 & 17.4 & 29.0 & 12 & 350 & 0.6 & 3.9 & 1.5 & 9.9 & 14.4 \\
\hline 0190 & 24.9 & 41.6 & 14 & 344 & 0.6 & 4.9 & 2.1 & 11.7 & 17.1 \\
\hline 3190 & 14.1 & 23.6 & 14 & 0 & 0.4 & 3.7 & 1.3 & 11.1 & 15.2 \\
\hline 2691 & 18.7 & 31.2 & 14 & 346 & 0.0 & 4.4 & 1.6 & 11.5 & 15.9 \\
\hline 1592 & 20.0 & 33.4 & 14 & 355 & 0.8 & 4.3 & 1.8 & 11.6 & 16.7 \\
\hline 3192 & 24.0 & 40.0 & 14 & 358 & 0.9 & 4.7 & 2.1 & 11.5 & 17.1 \\
\hline 3594 & 10.5 & 17.5 & 11 & 342 & 0.0 & 2.9 & 0.8 & 9.3 & 12.2 \\
\hline 0597 & 31.2 & 52.1 & 14 & 356 & 1.4 & 5.2 & 2.7 & 12.7 & 19.2 \\
\hline 2997 & 40.7 & 67.9 & 14 & 338 & 2.4 & 5.5 & 3.6 & 14.8 & 22.6 \\
\hline 1367 & 40.0 & 66.8 & 16 & 353 & 2.4 & 5.6 & 3.8 & 16.2 & 24.2 \\
\hline 4367 & 36.4 & 60.8 & 16 & 356 & 2.2 & 5.4 & 3.4 & 15.7 & 23.4 \\
\hline 5163 & 32.5 & 54.2 & 16 & 351 & 2.0 & 5.2 & 3.0 & 15.0 & 22.3 \\
\hline 6163 & 18.7 & 31.2 & 16 & 342 & 0.1 & 4.5 & 1.7 & 13.0 & 17.6 \\
\hline
\end{tabular}


Table F85

Wave Parameters and Water Levels by Storm, Profile: Rota 85

\begin{tabular}{|c|c|c|c|c|c|c|c|c|c|}
\hline \multirow{3}{*}{$\begin{array}{c}\text { Storm } \\
\text { No. }\end{array}$} & \multicolumn{4}{|c|}{----Wave Parameters---- } & \multicolumn{5}{|c|}{----------- Water Levels ------------} \\
\hline & $\mathrm{Hs}$ & $\mathrm{H} 1$ & $\mathrm{Tp}$ & Dir. & Surge & Ponding & Setup & Runup & Total \\
\hline & ft & ft & sec & deg az & ft & ft & ft & ft & ft \\
\hline 2348 & 13.8 & 23.0 & 11 & 353 & 0.9 & 3.2 & 1.1 & 11.6 & 15.7 \\
\hline 0150 & 6.9 & 11.5 & 11 & 3 & 0.0 & 2.0 & 0.4 & 7.9 & 9.9 \\
\hline 0853 & 19.0 & 31.8 & 14 & 1 & 0.8 & 4.2 & 1.6 & 21.2 & 26.2 \\
\hline 1953 & 12.2 & 20.3 & 11 & 355 & 0.6 & 3.1 & 0.9 & 11.1 & 14.8 \\
\hline 1557 & 10.5 & 17.5 & 11 & 2 & 0.7 & 2.7 & 0.8 & 10.5 & 13.9 \\
\hline 2057 & 21.7 & 36.2 & 14 & 359 & 0.5 & 4.6 & 1.8 & 21.4 & 26.5 \\
\hline 1861 & 11.5 & 19.2 & 12 & 354 & 0.0 & 3.2 & 0.8 & 11.3 & 14.5 \\
\hline 2762 & 25.9 & 43.3 & 16 & 359 & 1.0 & 5.0 & 2.3 & 26.3 & 32.3 \\
\hline 0163 & 22.3 & 37.3 & 14 & 335 & 0.3 & 4.7 & 1.8 & 21.4 & 26.3 \\
\hline 2563 & 39.0 & 65.2 & 16 & 334 & 1.7 & 5.7 & 3.3 & 27.2 & 34.6 \\
\hline 2965 & 15.1 & 25.2 & 12 & 332 & 0.1 & 3.7 & 1.1 & 13.6 & 17.4 \\
\hline 3367 & 37.4 & 62.5 & 16 & 355 & 2.5 & 5.4 & 3.3 & 27.1 & 35.0 \\
\hline 2168 & 10.5 & 17.5 & 12 & 357 & 0.4 & 2.9 & 0.8 & 10.9 & 14.2 \\
\hline 0571 & 12.2 & 20.3 & 12 & 356 & 0.1 & 3.2 & 0.9 & 11.7 & 15.1 \\
\hline 0676 & 13.5 & 22.5 & 16 & 313 & 0.2 & 3.8 & 1.1 & 18.1 & 22.0 \\
\hline 1977 & 16.0 & 26.8 & 12 & 357 & 0.5 & 3.8 & 1.2 & 14.7 & 19.0 \\
\hline 2379 & 8.9 & 14.8 & 10 & 3 & 0.2 & 2.4 & 0.6 & 8.8 & 11.4 \\
\hline 2187 & 22.0 & 36.7 & 14 & 334 & 0.4 & 4.6 & 1.8 & 21.4 & 26.4 \\
\hline 0188 & 25.6 & 42.7 & 16 & 358 & 1.4 & 4.9 & 2.3 & 26.3 & 32.6 \\
\hline 0289 & 17.4 & 29.0 & 12 & 350 & 0.6 & 3.9 & 1.3 & 15.0 & 19.5 \\
\hline 0190 & 22.0 & 36.7 & 14 & 350 & 0.7 & 4.6 & 1.8 & 21.3 & 26.5 \\
\hline 3190 & 14.1 & 23.6 & 14 & 0 & 0.4 & 3.7 & 1.1 & 17.1 & 21.2 \\
\hline 2691 & 18.7 & 31.2 & 14 & 346 & 0.0 & 4.4 & 1.5 & 20.8 & 25.1 \\
\hline 1592 & 20.0 & 33.4 & 14 & 355 & 0.8 & 4.3 & 1.7 & 21.4 & 26.5 \\
\hline 3192 & 22.3 & 37.3 & 14 & 356 & 0.9 & 4.6 & 1.9 & 21.2 & 26.6 \\
\hline 3594 & 10.5 & 17.5 & 11 & 342 & 0.0 & 2.9 & 0.7 & 10.1 & 13.0 \\
\hline 0597 & 31.2 & 52.1 & 14 & 356 & 1.4 & 5.2 & 2.5 & 21.5 & 28.0 \\
\hline 2997 & 40.7 & 67.9 & 14 & 338 & 2.4 & 5.5 & 3.4 & 24.7 & 32.6 \\
\hline 1367 & 40.0 & 66.8 & 16 & 353 & 2.4 & 5.6 & 3.5 & 27.9 & 35.8 \\
\hline 4367 & 36.4 & 60.8 & 16 & 356 & 2.2 & 5.4 & 3.2 & 26.6 & 34.3 \\
\hline 5163 & 35.4 & 59.2 & 16 & 348 & 1.2 & 5.6 & 3.0 & 25.5 & 32.4 \\
\hline 6163 & 18.7 & 31.2 & 16 & 342 & 0.1 & 4.5 & 1.5 & 23.8 & 28.4 \\
\hline
\end{tabular}




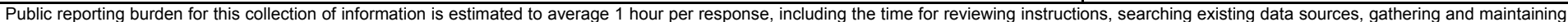

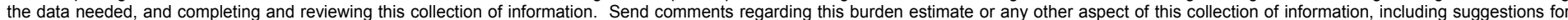

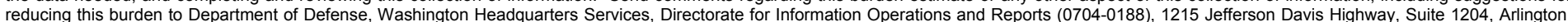

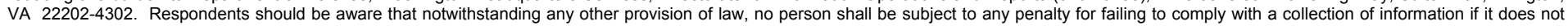
display a currently valid OMB control number. PLEASE DO NOT RETURN YOUR FORM TO THE ABOVE ADDRESS.

\begin{tabular}{l|c}
$\begin{array}{l}\text { 1. REPORT DATE }(D D-M M-Y Y Y Y) \\
\text { February } 2004\end{array}$ & $\begin{array}{c}\text { 2. REPORT TYPE } \\
\text { Final report }\end{array}$ \\
\hline
\end{tabular}

\section{TITLE AND SUBTITLE}

Typhoon-Induced Stage-Frequency Relationships for the Island of Rota, Commonwealth of the Northern Mariana Islands

3. DATES COVERED (From - To)

5a. CONTRACT NUMBER

5b. GRANT NUMBER

5c. PROGRAM ELEMENT NUMBER

5d. PROJECT NUMBER

5e. TASK NUMBER

5f. WORK UNIT NUMBER

8. PERFORMING ORGANIZATION REPORT NUMBER

ERDC/CHL TR-04-1

Coastal and Hydraulics Laboratory

U.S. Army Engineer Research and Development Center

3909 Halls Ferry Road

Vicksburg, MS 39180-6199

\section{SPONSORING / MONITORING AGENCY NAME(S) AND ADDRESS(ES)}

U.S. Army Engineer District, Honolulu

Fort Shafter, HI 96858-5440
10. SPONSOR/MONITOR'S ACRONYM(S)

11. SPONSOR/MONITOR'S REPORT NUMBER(S)

\section{DISTRIBUTION / AVAILABILITY STATEMENT}

Approved for public release; distribution is unlimited.

\section{SUPPLEMENTARY NOTES}

\section{ABSTRACT}

A set of typhoon-induced stage-frequency relationships was developed for inhabited coasts of the island of Rota, Commonwealth of the Northern Mariana Islands. The objective was to assist the Honolulu District in estimating extreme maximum inundation levels and maximum still-water levels with return period of up to 500 years. Calculations of surge, wind and pressure field, and wave characteristics were performed for 28 historical storms and four hypothetical variations of historical storms through application of numerical models. Wave-induced ponding, setup, and runup were calculated at 87 profile locations specified by the Honolulu District. The Empirical Simulation Technique was applied to calculate stage-frequency relationships based on historical storm parameters and calculated response to the storms. These relationships were calculated from the maximum total water levels computed for each storm (including storm surge, ponding, and runup) and from the maximum still-water levels for each storm (including storm surge, ponding, and wave setup). The methodology was calibrated to observations so that stage-frequency values for maximum total water level are expected to represent maximum debris line inundation levels.

\begin{tabular}{|ll|}
\hline 15. SUBJECT TERMS & Finite element modeling \\
Coastal flooding & Fringing reef \\
Empirical Simulation & Storm surge \\
\hline
\end{tabular}

16. SECURITY CLASSIFICATION OF:

\begin{tabular}{|l|l|}
\hline a. REPORT & b. ABSTRACT \\
UNCLASSIFIED & UNCLASSIFIED \\
\hline
\end{tabular}

c. THIS PAGE

UNCLASSIFIED
Typhoon modeling $\quad$ Wind wave modeling

Wave runup

Wave setup

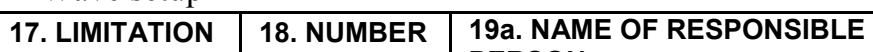
\begin{tabular}{l|l|l} 
OF ABSTRACT & OF PAGES & PERSON
\end{tabular}

140

19b. TELEPHONE NUMBER (include area code) 